MARCO ANTONIO PEREZ DE OLIVEIRA

\title{
A COISA JULGADA SOBRE A SENTENÇA GENÉRICA COLETIVA
}

\author{
DisSERTAÇão De MeSTRAdo \\ Orientador: Prof. Dr. Walter Piva Rodrigues
}

FACULDADE DE DIREITO DA USP

SÃO PAULO

2012 


\title{
MARCO ANTONIO PEREZ DE OLIVEIRA
}

\section{A COISA JULGADA SOBRE A SENTENÇA GENÉRICA COLETIVA}

\author{
Dissertação de Mestrado apresentada à Banca Examinadora da \\ Faculdade de Direito da Universidade de São Paulo, como \\ exigência parcial para a obtenção do título de Mestre em Direito, \\ sob a orientação do Prof. Dr. Walter Piva Rodrigues
}

FACULDADE DE DIREITO DA USP

SÃO PAULO

2012 
Banca Examinadora 


\section{Agradecimentos}

Quero deixar registrados alguns agradecimentos a gestos e posturas que contribuíram para o resultado aqui apresentado, certo de incorrer em omissões para manter a brevidade. Ao professor doutor Walter Piva Rodrigues, agradeço a orientação ao mesmo tempo segura e aberta à independência de pensamento. Ao constante amigo Luiz Guilherme Dellore, agradeço desde o incentivo ao ingresso no programa de mestrado até as valiosas críticas à versão preliminar do texto da dissertação. A solidariedade dos colegas da Advocacia-Geral da União, em especial na pessoa de Cristiane Blanes, permitiu meu afastamento em um particularmente intenso julho de 2011, ao longo do qual a maior porção do texto foi redigida. E, finalmente, à minha esposa, Roberta Patriarca Magalhães, quero agradecer não apenas suas observações e revisão, mas especialmente sua compreensão para com meus períodos de isolamento ao longo da pesquisa e composição. 


\section{RESUMO}

A dissertação se ocupa da análise da coisa julgada sobre a sentença genérica coletiva de procedência que, segundo a regra do artigo 95 do Código de Defesa do Consumidor brasileiro, tem por objeto a fixação de responsabilidade do réu para efeitos da tutela coletiva de direitos individuais homogêneos.

O primeiro capítulo analisa a ação civil coletiva do direito brasileiro, com particular ênfase para a repartição da atividade cognitiva entre as questões comuns, objeto da ação coletiva propriamente dita, e das questões particulares que constituem objeto das ações complementares em que se apuram a titularidade e o conteúdo dos direitos individuais a cuja tutela se direciona o procedimento.

O capítulo seguinte realiza uma revisão da teoria da coisa julgada, sob a ótica da vinculação da jurisdição moderna à tutela dos direitos previamente reconhecidos pela ordem jurídica, que passam a constituir a unidade mínima estrutural do processo civil.

Finalmente, o último capítulo classifica a sentença genérica coletiva como modalidade de sentença parcial de mérito e examina diferentes teorias que buscaram explicar a estabilidade desse tipo de decisão. Os resultados atingidos são aplicados para se estudar a viabilidade do estabelecimento de parâmetros de liquidação na própria sentença genérica e a obrigatoriedade das questões resolvidas pela sentença genérica em ações conexas à ação coletiva.

Palavras-chave: processo coletivo - sentença genérica coletiva - coisa julgada 


\section{ABSTRACT}

This dissertation deals with the analysis of the effects of res judicata upon the generic collective sentence which, according to article 95 of Brazilian Consumers Defense Code, has for object the fixation of defendant's liability in the context of collective redress of individual rights.

First Chapter analyses the civil collective action in Brazilian law, emphasizing the bifurcation of procedure that separates the decision of common issues, which are tried in the collective suit; and of particular issues, that constitute the object of complementary suits in which are tried the ownership and contents of individual claims.

The following Chapter reviews the theory of res judicata in civil procedure, under the perspective of modern jurisdiction's function of protection of rights previously recognized by law, making them the minimal structural unit of civil procedure.

Finally, the last Chapter classifies the generic collective sentence as a species of partial sentence on the merits, and reviews different theories that tried to explain the stability of this sort of decision in order to identify its defining features. The results achieved are applied in the study of admissibility of claim-value definition in the very generic collective sentence, as well as in the binding effect of the common issue resolution in parallel suits.

Keywords: class action - generic collective sentence - res judicata 


\section{SUMÁRIO}

2. A AÇÃo CIVIL COLETIVA 15

2.1. O contexto social e político em torno da tutela coletiva............................................................ 15

2.1.1. Transformações sociais no século XX e seu impacto no processo civil ...................... 16

2.1.2. Tutela coletiva de direitos e tutela de direitos coletivos ................................................. 22

2.1.3. Repercussões políticas: participação pelo processo e acomodação das instituições.... 26

2.2. O sistema brasileiro de tutela coletiva de direitos .............................................................. 29

2.2.1. Antecedentes na tutela coletiva: da ação popular à ação civil pública......................... 30

2.2.2. O Código de Defesa do Consumidor e a "ação de classe brasileira" ........................... 31

2.3. A reorganização da atividade cognitiva na tutela dos interesses individuais homogêneos: a simultânea reunião e fragmentação das lides individuais ............................. 34

2.3.1. O objeto da ação coletiva e o conceito processual de homogeneidade ........................ 39

2.3.1.1. Direitos homogêneos excluídos da tutela coletiva ......................................... 43

2.3.1.2. Limitação territorial dos efeitos da sentença e determinação da juntada da relação de associados ou filiados .................................................................. 44

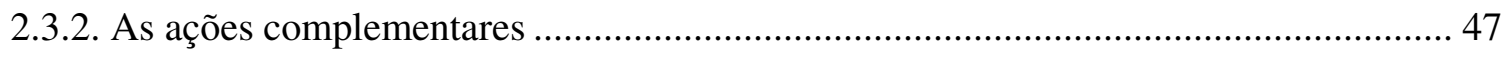

2.3.2.1. Ações individuais de cumprimento ................................................................ 49

2.3.2.2. Ação de liqüidação e execução coletiva........................................................ 52

2.4. A legitimação para a causa na ação coletiva e nas ações complementares ............................ 54

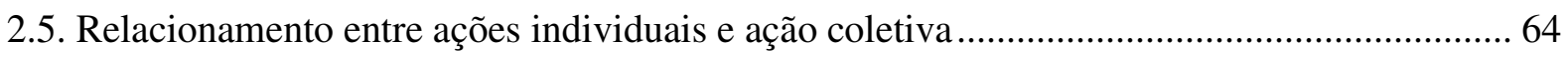

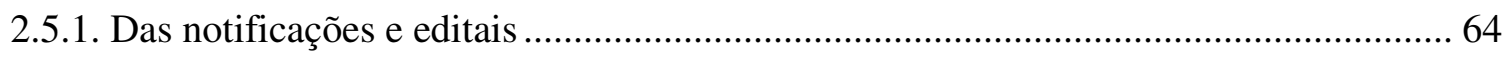

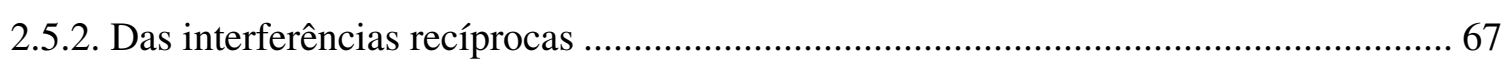

2.6. Da coisa julgada erga omnes e secundum eventum litis ................................................... 71

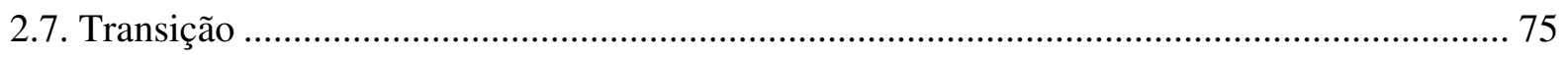

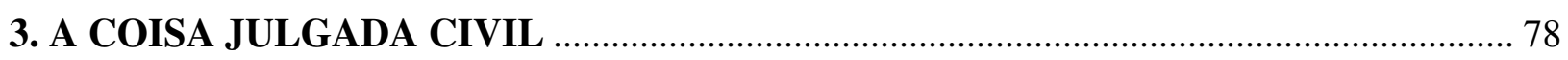

3.1. Condicionantes político-institucionais para a moderna teoria da coisa julgada: a integração da jurisdição ao Estado e o surgimento da ciência do processo como ramo

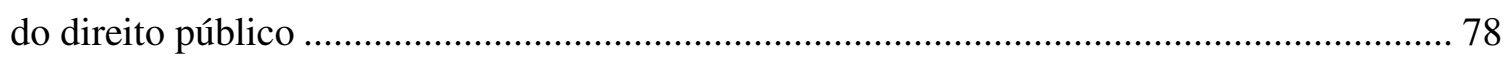

3.1.1. As relações entre o juiz e a lei: a dualidade do ordenamento jurídico .......................... 84

3.1.2. O conceito de tutela jurisdicional e a relação jurídica como "entidade mínima estrutural" do objeto litigioso do processo ................................................................... 92

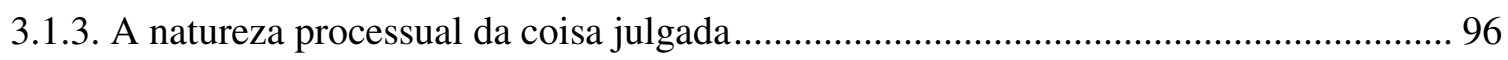

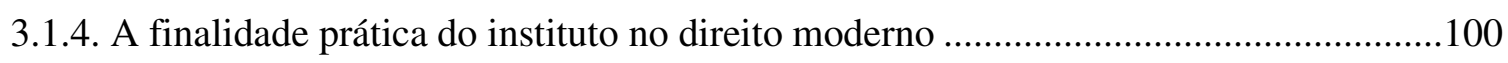


3.2. Conceito de coisa julgada.

3.2.1. Distinções necessárias: trânsito em julgado, coisa julgada formal e coisa julgada material

3.2.2. O desenvolvimento da doutrina em torno da natureza da coisa julgada 106

3.2.3. Distinção entre a eficácia da sentença e a coisa julgada 114

3.2.3.1. A evolução da formulação original de Liebman: as contribuições de Ovídio Batista e de Barbosa Moreira.

3.2.3.2. A elaboração de Botelho de Mesquita: eficácia declaratória e elemento declaratório

3.2.4. Efeito negativo da coisa julgada...... 125

3.2.5. Efeito ativo da coisa julgada 126

3.2.6. A eficácia preclusiva da coisa julgada 128

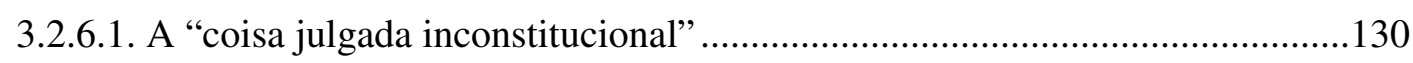

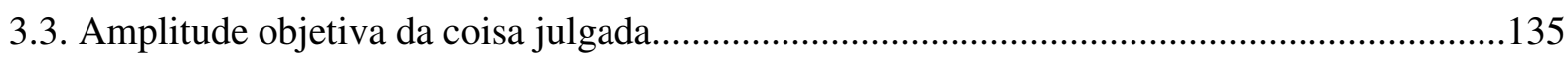

3.3.1. Limitação à lide e às questões decididas 135

3.3.1.1. O objeto do processo e seus elementos de identificação..... 141

3.3.1.2. Os problemas relacionados à determinação da causa petendi. 145

3.3.2. Os elementos lógicos da sentença não são cobertos pela coisa julgada. 150

3.3.3. Em particular: as questões prejudiciais 153

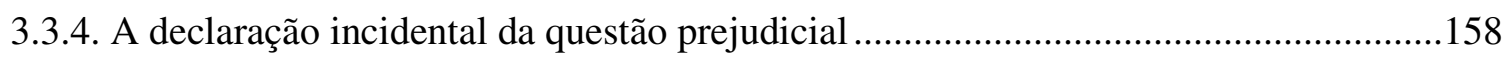

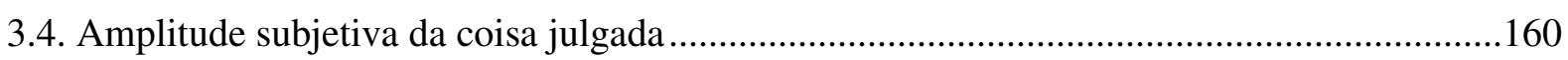

3.4.1. Os adquirentes do bem litigioso e a coisa julgada ...................................................... 166

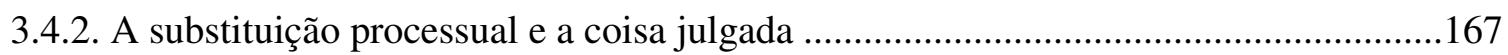

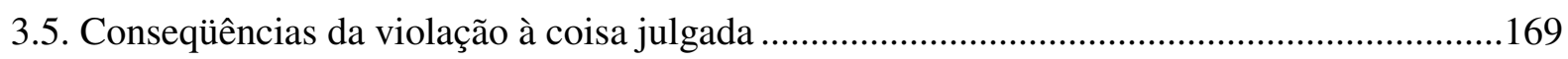

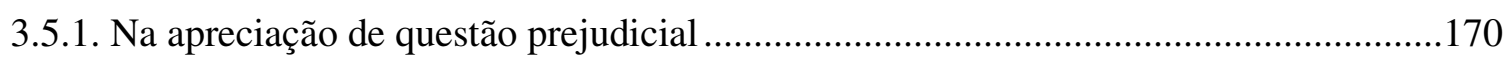

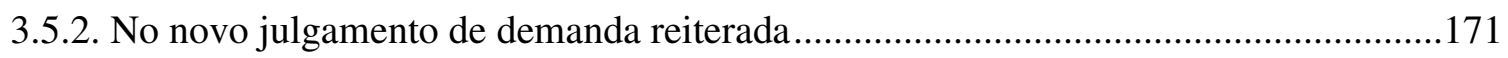

3.6. Transição

\section{A COISA JULGADA SOBRE A SENTENÇA GENÉRICA COLETIVA .......................173}

4.1. Enquadramento dogmático da sentença genérica coletiva ................................................173

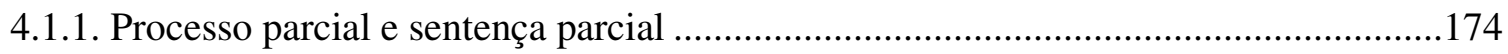

4.1.2. Sentenças parciais no Código de Processo Civil de 1973 ............................................178

4.1.3. Natureza das sentenças genéricas e das sentenças de liqüidação: divergências da doutrina.

4.1.3.1. Crítica ao enquadramento das sentenças parciais nas categorias de classificação da sentença que contém a tutela jurídica integral.....................182

4.2. Teorias sobre a coisa julgada na sentença parcial de mérito ..... 185 
4.2.1. Dificuldades para aplicação da disciplina da coisa julgada à sentença parcial: a incerteza (o problema da "liqüidação zero") e a ausência de elemento volitivo..........186

4.2.2. Teoria da preclusão extraprocessual ...........................................................................189

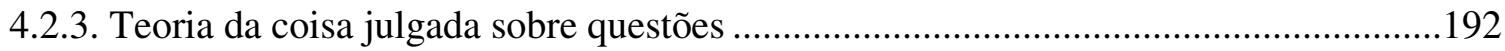

4.2.4. Teoria da coisa julgada sobre a fattispecie parcial ......................................................196

4.2.5. O tratamento doutrinário e jurisprudencial do princípio da "fidelidade da liqüidação ao título"

4.3. A decisão parcial sobre a fattispecie e a coisa julgada coletiva ...........................................204

4.3.1. Estados Unidos: as issue class actions e a reexamination clause ..............................204

4.3.2. A coisa julgada secundum eventum litis e a definição do instituto como simples expansão de eficácia da sentença: crítica

4.3.3. Coisa julgada "erga omnes" sob o enfoque da coisa julgada sobre a fattispecie

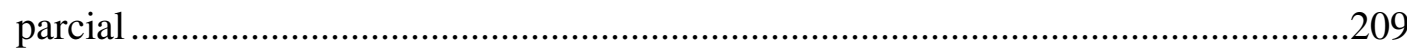

4.3.3.1. Questões cobertas pela coisa julgada coletiva............................................211

4.3.3.2. O "caso concreto" na ação civil coletiva ........................................................213

4.4. Aplicações

4.4.1. Estabelecimento genérico de padrões de liqüidação em direitos individuais homogêneos

4.4.1.1. Complexidade da prova do valor individual do dano

4.4.1.2. Conteúdo da obrigação deve obrigatoriamente ser arbitrado

4.4.1.3. Importância da fixação do objeto litigioso na ação civil coletiva

4.4.2. Exclusão da coisa julgada erga omnes em demandas conexas ao caso concreto decidido na ação coletiva

4.4.5. Síntese: pontos de contato e pontos de diferenciação em relação à coisa julgada material. 


\section{APRESENTAÇÃO}

O assunto a que nos dedicaremos ao longo das linhas que compõem esta dissertação é a coisa julgada que se forma sobre a "sentença genérica coletiva" de que trata o artigo 95 da Lei $n^{\circ} 8.078 / 90$, o Código de Defesa do Consumidor. Foi este o diploma legislativo que regulamentou em nosso país uma forma de tutela coletiva de direitos individuais característicos das relações de massa da sociedade industrial, inspirada na ação de classe (class action) do direito norte-americano. A nossa preocupação ao longo do estudo será essencialmente dogmática, e centrada no instituto da coisa julgada: iremos investigar se a estabilidade dessa decisão pode de fato ser conduzida à categoria da coisa julgada material, se ela se limita à coisa julgada formal, ou se na verdade se trata ainda de um terceiro instituto, de natureza diversa, criado pelo legislador para atender às finalidades específicas da ação coletiva. E o método para se chegar a tais respostas não pode ser outro senão o de analisar os efeitos que a lei atribui ao trânsito em julgado da sentença genérica.

Ao contrário do que essa breve descrição do objeto do trabalho pode dar a entender, nosso objetivo final não é a de produzir um mero exercício acadêmico, que fique limitado ao plano conceitual. Em nosso modo de entender, a importância de bem aprender a natureza e os efeitos que a lei atribui à chamada "coisa julgada erga omnes" de que se reveste a sentença genérica coletiva é justificada principalmente pelo fato de que ela é o elemento de articulação estrutural que une os diversos processos que se fazem necessários para a entrega final da tutela jurisdicional coletiva que tenha por objeto os direitos individuais homogêneos. O entendimento do seu modo de funcionar, por isso, se constitui em um pressuposto para a efetividade da tutela coletiva de direitos.

A nota distintiva do procedimento especial criado para viabilizar essa forma de proteção coletiva reside em ter utilizado, o legislador, a técnica de fracionar a cognição das questões necessárias ao reconhecimento dos direitos subjetivos materiais em processos distintos e sucessivos: inicialmente, uma ação coletiva em que se analisam as questões comuns, com o objetivo exclusivo de se "fixar a responsabilidade" do réu; e, posteriormente, a ela se seguem uma ou mais ações complementares, dedicadas a analisar as questões particulares de cada credor ou, na eventualidade de não acorrerem estes pessoalmente para deduzir suas pretensões de habilitação e liqüidação individuais, a se arbitrar uma liqüidação substitutiva, que abranja os danos globalmente sofridos pela 
“classe". Dessa forma, enquanto a coisa julgada material foi pensada para assegurar a estabilidade da sentença na possibilidade apenas eventual de reiteração da lide em processos futuros, em se tratando da ação civil coletiva a existência de processos futuros é um dado certo e indispensável para que se efetive a tutela jurisdicional dos direitos individuais de natureza homogênea.

E assim, quando dissemos, há pouco, que a coisa julgada erga omnes é o elemento de articulação estrutural entre esses vários processos, o que quisemos realçar é que o regime jurídico desse instituto processual é que determinará os limites e o objeto tanto da ação coletiva genérica como o das ações complementares de liqüidação, sejam elas de natureza individual ou coletiva. Nada obstante as conhecidas divergências doutrinárias que existem em torno do conceito de coisa julgada, bem como de seus contornos, há um elemento que se apresenta como mínimo denominador comum nas definições de todos os autores que se ocuparam do assunto: o fato de que ela gera vínculos a que ficam adstritos os juízes de processos ulteriores, seja para impedir que julguem determinadas questões, seja para observarem o já decidido como pressuposto lógico na decisão de uma nova demanda. Em suma, trata-se de idéia de que um imperativo de ordem prática exige que algum grau de estabilidade seja dado às decisões judiciais. Identificar a abrangência dos vínculos que a sentença genérica coletiva irradia sobre os processos complementares, ou seja, o quanto dela deve ser aproveitado e o quanto deve ser desprezado, significa dizer qual é a abrangência possível do objeto litigioso na fase coletiva e, portanto, qual a potencialidade de resolução concentrada de questões que o procedimento pode oferecer.

Como se pode perceber, a intenção do trabalho é descrever qual a essência e o modo de se manifestar da coisa julgada erga omnes primordialmente em seus aspectos objetivos. Nisto, acreditamos, a análise a que nos propomos pode representar uma contribuição que lance novas luzes sobre esse novo instituto, que apesar de ter sido profundamente analisado no que diz respeito à sua extensão subjetiva, de disciplina legal bem definida pelas figuras da eficácia erga omnes e secundum eventum litis, aspectos que atualmente se reconhece serem plenamente compatíveis com o devido processo legal e com os princípios gerais da coisa julgada, não recebeu ainda atenção mais aprofundada justamente naquilo que está relacionado à sua própria essência.

A suposição que poderia se entender implícita no silêncio da doutrina é a de que a disciplina da coisa julgada no Código de Processo Civil (Lei n. 5.869/73), muito detalhada e de uma clareza ímpar entre as principais legislações processuais, seria adequada para 
resolver os problemas relacionados à estabilização da sentença genérica coletiva frente aos futuros processos complementares. Muito embora o Código de Defesa do Consumidor (Lei n. 8.078/90) tenha sido bem mais parcimonioso ao dispor sobre a coisa julgada coletiva no inciso III do artigo 103, nos parece que de seu próprio sistema podemos retirar elementos que nos permitem pôr em questão se essa transposição poderia ser, de fato, tão simples como se sugere.

Vejamos. Segundo a opção acolhida pelo Código de 1973, a coisa julgada material incide apenas sobre o dispositivo da sentença, fazendo irrelevantes os elementos de sua fundamentação: fatos, fundamentos jurídicos, questões prejudiciais conhecidas pelo juiz (art. 469 do Código de Processo Civil). Esse regime se filia a uma concepção chiovendiana da coisa julgada, segundo a qual somente têm aptidão para se tornar imutáveis e indiscutíveis as sentenças que atribuam um bem da vida ao autor ou ao réu ${ }^{1}$. A sentença coletiva genérica de procedência, de seu turno, nada determina em caráter definitivo: ela fixa premissas, no mínimo a "responsabilidade do réu" (art. 95 da Lei no 8.078/90), que devem se integrar a outros elementos em processos ulteriores de habilitação e liqüidação para que se complete o comando condenatório (art. 98 e 100 da Lei n. 8.078/90), que pode nunca se integrar, se eventualmente se concluir que na realidade não houve dano indenizável. A sua estabilidade pode ser apenas relativa. Essa característica torna difícil determinar sobre que porção da sentença incidirá à coisa julgada. Ou se identifica um núcleo "dispositivo" na sentença civil coletiva que fixa a responsabilidade genérica do réu, ou seremos levados a concluir que a coisa julgada incidirá apenas sobre elementos lógicos necessários à definição da vontade concreta da lei, afastando assim a aplicabilidade do já citado artigo 469, em uma disciplina que seria diametralmente oposta à do Código de 1973. Mas se admitirmos que a estabilidade proporcionada pela coisa julgada coletiva se forma apenas sobre questões, e não sobre direitos, como é possível compatibilizar esse entendimento com as teorias da ação e da coisa julgada?

As perplexidades não se esgotam nisso. Em seu regime jurídico ordinário, os limites objetivos da coisa julgada são dados pelos limites da lide, tal como apresentada em juízo pela petição inicial e pela resposta do réu, conforme se extrai do artigo 468 do Código de Processo Civil. O problema que se coloca, então, é o de determinarmos em que consiste a lide na ação civil coletiva. Poderia ela realmente se esgotar na fixação de

\footnotetext{
${ }^{1}$ A respeito da concepoção de GIUSEPPE CHIOVENDA acerca do conteúdo das sentenças aptas a serem objeto de coisa julgada, ver especialmente Cosa giudicata e preclusione. In: SAGGI di diritto processuale civile. Milano: Giuffrè, 1993, v. 3, p. 231-283.
} 
responsabilidade genérica do réu, que é objeto da ação civil coletiva? Sabemos que a tutela que se busca por meio desse procedimento não é um reconhecimento abstrato de responsabilidade a que não se liga qualquer conseqüência jurídica; busca-se na realidade a tutela condenatória, e o ressarcimento destinado a cada um dos indivíduos prejudicados pela conduta danosa, objetivo que somente será atingido mediante a combinação do resultado de sucessivos processos. Reconhecido, assim, certo escopo comum a esse sistema, cabe perguntar se em seu interior o modo de operar da coisa julgada deve ser semelhante ao da coisa julgada material e, portanto, se seria adequada a aplicação de regras como a do artigo 468. Afinal, as necessidades práticas de estabilidade exigidas da sentença genérica, nesse contexto, não são as mesmas exigidas após o trânsito em julgado de um processo que julgue integralmente o mérito de uma pretensão.

As respostas que alcancemos no aprofundamento dessas indagações terão importantes repercussões para efeitos de determinar os usos possíveis da ação civil coletiva, seus limites e possibilidades. De fato, entender como se articulam a sentença coletiva e as ações complementares, por meio da assim chamada coisa julgada erga omnes, pode nos ajudar a determinar o grau de flexibilidade que o procedimento especial admite na distribuição da matéria litigiosa em cada uma das fases que o compõem, e sua capacidade de adaptação para o tratamento dessa realidade naturalmente fluída e variável que são os interesses individuais homogêneos. Por isso, o estudo do modo de ser da coisa julgada erga omnes, de que se reveste a sentença civil coletiva de procedência, ao fim e ao cabo nada mais é do que um meio para respondermos uma pergunta muito prática: poderia ser mais bem aproveitado o instrumento de tutela coletiva de direitos da lei brasileira? Algo a se observar sobre a ação civil coletiva é o fato de que muitos que sobre ela escrevem lamentam a baixa efetividade do procedimento, e talvez não seja exagero dizer que as expectativas que se criaram em torno de sua utilização, por ocasião da edição do Código de Defesa do Consumidor, tenham sido em boa medida frustradas ao longo dos pouco mais de vinte anos de vigência da lei. É bastante sintomático, a propósito, que nos debates em torno da reforma do processo civil se discuta um "incidente de coletivização de demandas" que se colocaria como alternativa à ação coletiva na tutela dos direitos de massa.

Tais considerações justificam a necessidade de estudarmos a estrutura procedimental da ação civil coletiva, do ponto de vista dogmático, para que dela possamos apontar o máximo de suas potencialidades, e para que assim sejam postas em uso, ou, constatando limitações sérias e incontornáveis, indicarmos as deficiências da legislação 
como subsídio para reformas futuras. Daí sustentarmos que o objeto desta dissertação é a natureza da coisa julgada que se forma sobre a sentença genérica coletiva, sob um prisma dogmático, sim, mas isto representa apenas o começo das intenções que motivaram o projeto.

A dissertação será estruturada em três capítulos, que reúnem por afinidade os grupos de principais questões a serem analisadas, segundo a divisão que passamos a descrever. O primeiro capítulo trata da "ação civil de responsabilidade pelos danos individualmente sofridos", tal como disciplinada pelos artigos 91 e seguintes do Código de Defesa do Consumidor. Nele se pretende expor os aspectos gerais que envolvem a defesa de direitos individuais a título coletivo, compreendendo os objetivos de política legislativa a que a lei visou atender e o regime jurídico-processual positivado pelo Código de Defesa do Consumidor. Dentre as regras desse procedimento especial, analisaremos com mais cuidado a legitimação ad causam, dados os reflexos que a opção feita pelo legislador nesse campo acarreta sobre o regime da coisa julgada; o regime de interferência recíproca entre ações individuais e coletivas; a repartição da atividade cognitiva entre os processos coletivos e complementares; e, ainda que de maneira superficial, já que o assunto será retomado no último capítulo, o regime de amplitude subjetiva da coisa julgada erga omnes e secundum eventum litis. Consignamos que, por não ser este o foco do trabalho, este primeiro capítulo não buscará exaurir todos os aspectos da ação civil coletiva que seriam dignos de aprofundamento, limitando-se a destacar aqueles que exercem maior influência no seu peculiar regime de coisa julgada.

O segundo capítulo se dedica ao estudo da "teoria geral da coisa julgada" e da disciplina jurídica que o tema encontra no Código de Processo Civil de 1973. Como antecedentes necessários à compreensão das soluções adotadas pela lei, iniciaremos pelo estudo de circunstâncias que entendemos serem condicionantes da teoria da coisa julgada: o perfil da jurisdição civil no Estado moderno, a dualidade do ordenamento jurídico, o conteúdo mínimo do processo, o caráter processual e a finalidade prática do instituto. Após uma revisão da literatura e do desenvolvimento da doutrina acerca do tema, estudaremos o regime jurídico positivo da coisa julgada material, expondo os efeitos positivo e negativo com os quais se manifesta, bem como a o expediente técnico em que se apóia o instituto, a chamada eficácia preclusiva do deduzido e do dedutível. Dedicaremos ainda parte do capítulo a analisar os limites objetivos e subjetivos da coisa julgada, e por fim analisaremos as conseqüências de sua violação. 
O terceiro e último capítulo, voltado à "coisa julgada sobre a sentença genérica coletiva", buscará realizar a síntese entre os dois capítulos precedentes, analisando como a fragmentação da análise do mérito em sucessivas sentenças repercute sobre a aplicabilidade das regras da coisa julgada material à sentença genérica coletiva. Tendo em conta os elementos antecedentes com que abrimos o segundo capítulo, estudaremos então três modos de se interpretar a estabilidade das decisões definitivas parciais de mérito no processo civil: (i) a simples preclusão, nos moldes da doutrina de CHIOVENDA que rejeita a aptidão de formação de coisa julgada sobre sentenças que não reconheçam a vontade concreta da lei sobre um bem jurídico; (ii) a coisa julgada sobre pontos de fato ou direito, por meio da qual ENRICO REDENTI rompeu com a tradição chiovendiana, dando origem a diferentes teorias que convergem em admitir que decisões judiciais que, resolvendo pontos antecedentes, não chegam a um juízo definitivo sobre a pretensão; e (iii) a peculiar coisa julgada parcial sobre a fattispecie, concebida por VITTORIO DENTI, que teria uma disciplina própria, ao mesmo tempo mais ampla e mais restrita do que a coisa julgada ordinária.

Buscaremos então, a partir das considerações feitas por essas diferentes teorias, delinear qual a natureza e qual o modo de funcionar do objeto de nosso estudo. Com esse posicionamento tomado, analisaremos aplicações específicas do modo como se manifesta a coisa julgada erga omnes sobre a sentença coletiva genérica. A primeira delas é a possibilidade de serem estabelecidos parâmetros homogêneos de liqüidação que vinculem os juízes dos processos complementares, ampliando a margem de cognição concentrada na fase coletiva segundo a variação do núcleo de homogeneidade e da margem de heterogeneidade de cada caso concreto. A segunda é a viabilidade de aproveitamento das questões de fato ou direito decididas pela sentença genérica em demandas individuais conexas, mas diferenciadas daquelas próprias à classe representada. Trata-se de saber se os elementos lógicos resolvidos pela sentença genérica têm eficácia panprocessual autônoma, fora do contexto da lesão de massa sustentada na inicial. Em poucas palavras, portanto, o objeto do trabalho é identificar em que medida a excepcional sentença genérica coletiva tem a propriedade de conferir novas dimensões ao tradicional instituto da coisa julgada, justificando que voltemos nossas atenções a ele nesse novo contexto. 


\section{A AÇÃO CIVIL COLETIVA}

\subsection{O contexto social e político em torno da tutela coletiva}

Um trabalho que pretenda delinear os traços característicos da coisa julgada que recobre a sentença de condenação genérica coletiva, própria da ação civil brasileira para a defesa dos "direitos individuais homogêneos", exige de início uma breve contextualização destinada a justificar a importância do estudo de um tema clássico, como o é a coisa julgada, à vista das peculiaridades da ação civil coletiva. Isto se deve a duas razões: de um lado, sabemos que a coisa julgada é um dos temas mais explorados da ciência processual ${ }^{2}$, de modo que é interessante que uma dissertação sobre o instituto tome um novo enfoque como ponto de partida. Sob outro ângulo, vivemos uma fase de rápidas mudanças no desenvolvimento da sociedade, em que o conceito clássico de coisa julgada se encontra em $\operatorname{crise}^{3}$ (a dimensão que tomou o debate em torno da relativização da estabilidade do julgado bem evidencia esse fenômeno).

Mas essa é uma crise mais ampla que coloca em questão a própria concepção do Estado moderno e de suas instituições centrais, como a representação política, o direito positivo e a jurisdição, pressionados pela dificuldade de governar uma sociedade cada vez mais complexa e conflituosa. O processo coletivo é uma das respostas que o Estado oferece a essa crise, buscando recuperar sua autoridade na imposição do direito (a Justiça estatal) em áreas onde ele era inacessível, e manter assim sua capacidade de resolução dos conflitos de forma institucionalizada. Esse tipo de processo, contudo, se manifesta em formas mais fluidas, e nelas a coisa julgada assume novas dimensões até então desconhecidas ou, no mínimo, obscurecidas pela jurisdição típica do modelo liberal. Para que possamos ao final compreendê-las, antes é necessário buscar entender o ambiente em que se desenvolve essa pequena revolução do direito processual do século passado, representado pelas ações coletivas.

\footnotetext{
${ }^{2}$ Esse fato, contudo, não levou a uma uniformidade de entendimento sequer sobre o conceito do instituto, conforme ressaltam BARBOSA MOREIRA (Ainda e sempre a coisa julgada. In: __ Direito processual civil: ensaios e pareceres. Rio de Janeiro: Editor Borsói, 1971. p. p. 133) e ADROALDO FURTADO FABRÍCIO (A coisa julgada nas ações de alimentos. Revista de Processo, São Paulo, n. 62, p. 19, abr./jun. 1991).

${ }^{3}$ CAMPILONGO, Celso Fernandes. Política, sistema jurídico e decisão judicial. 2. ed. São Paulo: Saraiva, 2011. p. 39.
} 
Nosso plano consiste em indicarmos brevemente as causas que estiveram associadas ao surgimento dessa nova realidade em que consiste o processo coletivo, para em seguir expormos as duas vertentes técnicas em que ele atualmente se desdobra (tutela de direitos coletivos e tutela coletiva de direitos), e, por fim, analisarmos as repercussões que sua introdução no sistema de tutela dos direitos produz sobre a sociedade.

\subsubsection{Transformações sociais no século $X X$ e seu impacto no processo civil}

A sociedade predominantemente rural do século XIX, ao longo do século passado, migrou para as cidades, e a vida isolada do campo foi substituída pela vida em grandes aglomerações urbanas que colocaram os homens em contato cada vez mais freqüente uns com os outros ${ }^{4}$. O desenvolvimento de meios de comunicação e de transporte também contribuiu para o aumento das relações interpessoais, os contextos mais diversos, de modo que os contatos episódicos de antes foram substituídos por uma convivência freqüente, por si mesma geradora de riscos, incidentes e atritos.

Nas causas dessa mudança, a economia conheceu a adoção da produção em escala e uma quase que permanente expansão da indústria, impulsionada por um mecanismo de “destruição criativa" que permitiu ao capitalismo dessa época manter níveis de demanda elevados, por meio da constante inovação, que criava novas necessidades tão logo as anteriores se viam atendidas ${ }^{5}$. A massificação da produção não se sustentou sem que se fomentasse uma sociedade consumidora, de maneira que as relações entre produtores e destinatários dos bens de consumo passaram a centralizar as relações econômicas e sociais. De igual maneira, a crescente produção exigia trabalhadores, razão pela qual o emprego

\footnotetext{
${ }^{4}$ Sobre as transformações da sociedade e da litigiosidade no século passada, confiram-se, entre outros, CAPPELLETTI, Mauro. O acesso à justiça como programa de reformas e método de pensamento. Revista Forense, Rio de Janeiro, v. 104. n. 395, p. 209-224, jan/fev. 2008; GRINOVER, Ada Pellegrini. Significado social, político e jurídico da tutela dos direitos difusos. Revista de Processo, São Paulo, n. 97 , p. 9-15, jan./mar. 2000; MONTERO AROCA, Juan. El derecho procesal en el siglo XX. Madrid: Tirant lo Blanch, 2000; SALLES, Carlos Alberto de. Processo civil de interesse público. In: (Org.). Processo civil e interesse público: o processo como instrumento de defesa social. São Paulo, Revista dos Tribunais, 2003. p. 39-77.

${ }^{5} \mathrm{O}$ modelo de produção em escala, em que se diminuem os custos de produção a partir da padronização e simplificação de tarefas, é creditado ao modelo teórico do engenheiro FREDERICK WINSLOW TAYLOR e à linha de produção criada pelo industrial HENRY FORD, sendo por isso conhecido como modelo taylorista-fordista. O conceito de destruição criativa foi elaborado por JOSEPH SCHUMPETER para responder por que, ao contrário do que previra KARL MARX em $O$ capital, a expansão do capitalismo na transição do século XIX para o XX não levou o sistema ao colapso (Capitalism, socialism and democracy. New York: Harper Collins, 2008).
} 
assalariado assumiu uma posição central na economia. Em ambos os campos, a freqüência das relações de massa contribuiu igualmente para elevar exponencialmente os conflitos intersubjetivos, caracterizados pela sua uniformidade ${ }^{6}$ e pela desproporção de forças entre a indústria e os trabalhadores ou consumidores. Além disso, a escala da produção industrial fez com que a atividade econômica gerasse impactos cada vez mais elevados e significativos sobre o ambiente, e a sociedade passou a cobrar dos produtores os custos dessas interferências que antes eram considerados simples externalidades negativas da cadeia produtiva ${ }^{7}$.

No campo do ideário político, o postulado da igualdade entre os homens surgido no Iluminismo conheceu novas formas de expressão (em parte influenciadas elas experiências socialistas) e, em lugar da simples igualdade perante a lei que marcou o liberalismo clássico, as sociedades ocidentais organizaram-se na forma de um novo Estado social para perseguir também projetos de igualdade material que se expressam juridicamente na forma de direitos sociais a prestações positivas, diretas ou indiretas, por parte do poder público. Ao mesmo tempo, as garantias individuais continuaram a ser vistas como conquistas a serem preservadas, até com maior intensidade após a experiência do totalitarismo que culminou na II Grande Guerra, de modo que a dinâmica da vida política contemporânea está centrada na administração de uma tensão permanente entre os valores coletivo e individual ${ }^{8}$.

\footnotetext{
${ }^{6} \mathrm{~A}$ expressão interesses difusos, que veio a ser definida pela lei brasileira em termos mais específicos, surgiu na doutrina com referência a esses pequenos conflitos individuais uniformes e difusos na sociedade. Nesse sentido MAURO CAPPELLETTI afirma que "gli interessi $<<$ diffusi >> rappresentano un fenomeno típico, e di crescente rilievo, nelle societá moderne, caratterizzate dal passaggio da un'economia prevalentemente basata su rapporti individuali ad un'economia in cui lavoro, produzione, scambi e consumi, ma anche educazione, turismo, comunicazioni, assistenza sociale e previdenziale, ecc., sono fenomeni $<<$ di massa $>$. (...)" (La dimensione sociale: l'acesso alla giustizia. In: Dimensioni della giustizia nelle società contemporanee. Bologna: Il Mulino, 1994. p. 86).

${ }^{7} \mathrm{O}$ problema das externalidades foi analisado com profundidade pelo economista RONALD COASE, que demonstrou em seu artigo The problem of social cost, de 1960, que a simples atribuição de responsabilidade civil pelos danos não seria capaz de desestimular práticas socialmente indesejadas, mas antes que esse objetivo somente seria atingido se o custo de poluir, por exemplo, fosse maior que o de não poluir (In: The firm, the market and the law. Chicago: University of Chicago Press, 1988. p. 95-156). Essas idéias viriam posteriormente a estimular o conceito de "deterrence", que orienta as ações de classe norteamericanas, especialmente quando elas assumem o objetivo de promover mudanças institucionais (institutional change).

${ }^{8}$ A teoria política registra certa ambigüidade na instituição do Estado de Direito social, caracterizado pela mediação entre os típicos valores liberais e os valores sociais. Na análise de NORBERTO BOBBIO, "a democracia social pretende ser, com respeito à democracia liberal, uma fase ulterior, na medida em que inscreveu na própria declaração dos direitos os direitos sociais, além dos direitos de liberdade; pretende ser, ao contrário, com respeito à democracia socialista, apenas uma primeira fase. Tal ambigüidade se revela na dupla crítica que a democracia social recebe, ora da direita, por parte do liberalismo intransigente, que nela entrevê uma diminuição das liberdades individuais; ora da esquerda, por parte dos socialistas impacientes, que a concebem como solução de compromisso entre o velho e o novo que, mais do que favorecer a realização do socialismo, a obstaculiza e a torna mesmo impossível" (Liberalismo e democracia. São Paulo: Brasiliense, 2007. p. 84).
} 
Esse quadro de grande complexidade que aqui se descreve apenas brevemente, embora comporte muitas inovações positivas para a sociedade (progresso da técnica e dos níveis médios de riqueza, reconhecimento de direitos fundamentais individuais e sociais etc.), gerou um cenário de conflituosidade jurídica freqüente e dispersa ${ }^{9}$. Além disso, o tipo de conflito dessa sociedade industrial e massificada se apresentava com características completamente diferentes daquelas que haviam chegado até então aos tribunais. Em lugar de disputas individuais em questões de valor econômico mais elevado, tipicamente em torno do domínio e da utilização da terra, envolvendo produtores e proprietários, cada vez mais a Justiça teve de lidar com pequenas causas que tinham por objeto a distribuição dos perigos dessa nova "sociedade do risco"10, fossem elas fundados em pequenos contratos (de trabalho, de consumo, de locação urbana) ou na responsabilidade civil. Esses campos do direito privado, como se sabe, passaram ao centro das atenções e sofreram notáveis transformações de forma a se adaptarem à nova realidade que então se impunha. Também a seguridade social característica do Estado social de direito, fosse ela prestada diretamente pelo Estado ou delegada ao sistema de seguros privados, se tornou campo de constantes tensões e conflitos. Em comum, todos esses tipos de disputas apresentavam a significativa diferença de não se limitarem mais a proprietários e produtores, mas de dizerem respeito às grandes massas de consumidores, trabalhadores, locatários ou segurados.

Ao mesmo tempo, os macro-interesses em conflito na sociedade, relacionados aos interesses comuns do povo - meio ambiente sadio e desenvolvimento econômico, livre concorrência e crescimento, patrimônio cultural e liberdade de iniciativa - viriam gradualmente a ingressar na arena jurídica por via da ampliação da noção de direitos fundamentais sociais e correspondente alargamento dos escopos do direito administrativo, transcendendo o âmbito exclusivamente político em que se dava o seu arbitramento, para também eles baterem às portas dos tribunais, ainda que sem reconhecimento expresso pela

\footnotetext{
9“A modernidade, como qualquer um que vive no final do século XX pode ver, é um fenômeno de dois gumes. O desenvolvimento das instituições sociais modernas e sua difusão em escala mundial criaram oportunidades bem maiores para os seres humanos gozarem de uma existência segura e gratificante que qualquer tipo de sistema pré-moderno. Mas a modernidade tem também um lado sombrio, que se tornou muito aparente no século atual". (GIDDENS, Anthony. As conseqüências da modernidade. São Paulo: Ed. UNESP, 1991. p. 16).

${ }^{10} \mathrm{~A}$ ampliação e a consciência dos riscos são uma das características mais marcantes da sociedade contemporânea, conforme a avaliação do sociólogo alemão ULRICH BECK, que descreve a incapacidade das instituições da modernidade para lidar com as múltiplas e incontroláveis possibilidades da sociedade atual. A propósito, vide os ensaios "A reinvenção da política: rumo a uma teoria da modernização reflexiva” (In: GIDDENS, Anthony; BECK, Ulrich; LASH, Scott. Modernização reflexiva: política, tradição e estética na ordem social moderna. São Paulo: Ed. da Universidade Estadual Paulista, 1994) e "The risk society: towards a new modernity" (London: Sage Publications, 1992).
} 
legislação: apresentam-se eles em juízo sob a forma jurídica de simples interesses gerais da sociedade, e não como direitos subjetivos atribuídos a pessoas. É dizer, esses conflitos chegam ao Judiciário sem que e lei tenha previamente estabelecido situação de vantagem pela qual um interesse deva preponderar frente ao que lhe é contraposto, mas apenas o seu reconhecimento segundo as fluídas fórmulas dos direitos sociais.

Esse cenário, como não poderia deixar de ser, se refletiu em uma crise do direito e também a uma crise do processo civil. "Crise do direito" porque, conforme essa litigiosidade dispersa se instalava na sociedade, foram surgindo centros de organização desses interesses - os entes intermediários e grupos de pressão - que postularam e obtiveram, do Legislativo e do Executivo, disposições específicas para atender os interesses que representavam, ora em favor de produtores, ora em favor de grupos de indivíduos dispersos. Surgiram assim diversos micro-sistemas normativos, que muitas vezes se interpenetram de maneira desordenada, com finalidade de disciplinarem campos específicos de relações sociais e econômicas. A unidade sistemática e a coerência normativa, buscadas pelo movimento das grandes codificações de que o Código Napoleônico foi o grande expoente, ruíram em uma profusão de leis especiais fragmentárias, destinadas a regulamentar de forma diferenciada grupos e situações particulares. A isso se somou a difusão de novas técnicas legislativas como as cláusulas gerais, os conceitos indeterminados ou conceitos-válvula, que outorgam uma margem de discricionariedade ao juiz ao decidir cada caso concreto, corroendo o ideal de certeza do direito legislado. Como resposta a essa crise, foram se desenvolvendo novas teorias da interpretação baseada nos princípios e em técnicas racionais de argumentação, visando a restaurar a uniformidade e racionalidade perdidas pela lei positiva (não é por acaso, assim, que a teoria da interpretação é um dos campos mais profícuos de pesquisa na filosofia do direito contemporânea).

E "crise do processo" porque nem os institutos do direito processual, nem os profissionais do direito (juízes e advogados), e nem tampouco as estruturas administrativas organizadas para a prestação da jurisdição estatal estavam preparados para lidar com esse inesperado afluxo das massas em direção aos tribunais com as pequenas demandas características da sociedade de massas. De início, foi percebido que existia uma barreira representada pelos custos do processo que, na prática, privava de proteção judicial os direitos de menor expressão econômica. Se essa barreira havia sido algo tolerável na sociedade pré-industrial, quando os pequenos conflitos tinham um papel secundário, ela 
passou a constituir um problema digno de mais atenções quando a eles se multiplicaram e se tornaram o litígio típico da sociedade de massas. Além disso, foi constatada uma desproporção de forças nesses conflitos, na medida em que os litigantes habituais conseguiam obter significativos ganhos de escala em comparação com os litigantes ocasionais, seja em termos de estratégia processual, seja em termos de especialização em teses jurídicas, seja com a sua simples capacidade de melhor resistir à passagem do tempo de duração do processo $^{11}$. Esses fatores levaram a graus acentuados de inefetividade do processo, que dava mostras de uma incapacidade patológica de promover a pacificação social pela justa composição dos $\operatorname{conflitos}^{12}$. E a litigiosidade que surgia na sociedade permanecia nela contida, latente, contribuindo para a corrosão da legitimidade estatal, que já se via desafiada em outros campos (por exemplo, na crise de representatividade dos parlamentos).

A reação a esse estado de coisas consistiu em um conjunto de profundas alterações nas características do direito processual civil e da administração da justiça, na busca de novas formas de prestação da jurisdição que se mostrem capazes de atender a demanda gerada por essa nova conflituosidade que emergiu da sociedade. Nesse sentido, no conhecido relatório da pesquisa sobre essas transformações financiada pela Fundação Ford (o "Projeto Florença"), de autoria de MAURo CAPPELlETti e BRYANT GARTH, é descrito um movimento global no sentido do "acesso à justiça" desses "novos direitos" que surgiram na sociedade industrial de massa. Esse movimento compreenderia três grandes grupos de mutações, a que se chamou de "ondas renovatórias" do processo civil ${ }^{13}$.

A primeira onda renovatória consistiu em um conjunto de medidas que visou assegurar o acesso dos necessitados à Justiça. Como se expôs há pouco, com a urbanização e a industrialização, grandes massas de pessoas de poucas posses, que no século anterior

\footnotetext{
${ }^{11} \mathrm{O}$ modo como se manifesta essa desproporção de forças entre "repeat-players" e "one-shooters" foi objeto de análise de MARC GALANTER em artigo de 1974, Why the haves come out ahead: speculations on the limits of legal change. Law and Society Review, v. 9.

${ }^{12 “(. . .) ~ e ́ ~ d e ~ s e ~ e s p e r a r ~ q u e ~ o s ~ i n d i v i ́ d u o s ~ t e n h a m ~ m a i o r e s ~ p r o b l e m a s ~ p a r a ~ a f i r m a r ~ s e u s ~ d i r e i t o s ~ q u a n d o ~ a ~}$ reivindicação deles envolva ações judiciais por danos relativamente pequenos, contra grandes organizações. Os novos direitos substantivos, que são característicos do Estado de bem-estar social, no entanto, têm precisamente estes contornos: por um lado, envolvem esforços para apoiar cidadãos contra os governos, os consumidores contra os comerciantes, o povo contra poluidores, os locatários contra os locadores, os proprietários contra os patrões (e os sindicatos); por outro lado, o interesse econômico de qualquer indivíduo - como autor ou réu - será provavelmente pequeno. É evidentemente uma tarefa difícil transformar esses direitos novos e muito importantes - para todas as sociedades modernas - em vantagens concretas para as pessoas comuns.” (CAPPELLETTI, Mauro; BRYANT, Garth. Acesso à justiça. Trad. de Ellen Gracie Bryant. Porto Alegre: Sérgio Antonio Fabris Editor, 1998. p. 29).

${ }^{13}$ MAURO CAPPELLETTI retoma o tema das "três ondas renovatórias", de maneira mais sistematizada, no artigo La dimensione sociale: l'acesso alla giustizia, cit., p. 71-92).
} 
não recorriam à jurisdição estatal, passaram a demandar do Estado a resolução dos conflitos surgidos dos pequenos contratos e incidentes aos quais suas vidas passaram a estar associados. Mas o acesso à Justiça lhes era impossibilitado pelos altos custos tradicionalmente vinculados à administração da justiça. Assim disseminaram-se medidas como a isenção de taxas, bem como a assistência jurídica gratuita financiada pelo Estado ou exercida em caráter pro bono, e os tribunais de pequenas causas.

A segunda onda renovatória foi caracterizada pela adaptação do processo à coletivização do direito, de modo a tutelar os interesses concernentes a bens coletivos, como o meio ambiente, o patrimônio histórico e cultural, i.a.; bem como interesses individuais caracterizados por sua uniformidade e sua difusão pela sociedade, por efeito da padronização das relações jurídicas e econômicas da sociedade de massas. O grande expoente da segunda onda, seguramente, é a class action norte-americana. Muito embora suas origens possam ser traçadas desde as cortes de equity medievais ${ }^{14}$, a ação de classe consiste em uma criação contemporânea, que surgiu no contexto da sociedade de massas para responder a seus problemas específicos. Na década de 70, o relatório de CAPPELLETTI e GARTH já indicava uma expansão significativa do modelo das ações representativas inspiradas pela experiência norte-americana. No início do Século XXI, relatórios mais recentes ${ }^{15}$ dão conta de ter se consumado uma verdadeira "globalização da ação de classe", que penetrou não apenas nos países da tradição da common law, mas também naqueles cujas instituições são moldadas segundo os conceitos da civil law do direito continental.

Os autores do relatório final do Projeto Florença falam ainda em uma terceira onda, que propõe uma reformulação mais radical dos princípios do processo civil tradicional com o objetivo do estabelecimento de uma justiça coexistencial, ou conciliativa, preocupada também em evitar que o litígio prejudique as relações de duração continuada que se desenvolvem nos ambientes de trabalho, consumo e convivência da sociedade de massas. É

\footnotetext{
${ }^{14}$ STEPHEN YEAZELL sublinha que a ação de classe moderna não pode ser considerada uma descendente direta das ações representativas do século XVII, como a doutrina a vinha tratando principalmente a partir de estudos de ZECHARIAH CHAFEE que defendera essa tese. Ele demonstra que essas ações normalmente não tinham em suas bases conflitos em torno da violação de direitos, mas visavam ou ao registro escrito ou à alteração do costume existente entre os grupos da sociedade feudal, na busca de estabilidade do direito costumeiro no contexto de uma sociedade em transição, pelo que assumiam tais ações um caráter mais normativo ou homologatório do direito vigente do que propriamente jurisdicional. (Group litigation and social context. Columbia Law Review, v. 77, 1977).

${ }^{15}$ HENSLER, Deborah; HODGES, Christopher; TULIBACKA, Magdalena (Eds.). The globalization of class actions: an overview. Thousand Oaks, California: Sage Publications, 2009. (The Annals of the American Academy of Political and Social Science Series, v. 622); e GRINOVER, Ada Pellegrini; MULLENIX, Linda; WATANABE, Kazuo. Os processos coletivos nos países de civil law $e$ common law: uma análise de direito comparado. XIII Congresso internacional de direito processual civil. São Paulo: Ed. Revista dos Tribunais, 2008.
} 
o contexto no qual se insere o estudo de meios alternativos de resolução de conflitos e de procedimentos simplificados e informais para a resolução de causas de baixa complexidade.

\subsubsection{Tutela coletiva de direitos e tutela de direitos coletivos}

Do ponto de vista da técnica processual, a expansão da tutela coletiva teve de lidar com duas realidades diversas. A primeira delas foi a judicialização de causas em que se colocava em questão a proteção da nova categoria dos direitos sociais, tais como o patrimônio comum histórico, arquitetônico e arqueológico, ou o meio ambiente: bens indivisíveis, insuscetíveis de apropriação exclusiva, de interesse geral de coletividades ou de toda a sociedade. A segunda foi o aparecimento de processos em que se buscava a proteção de direitos individuais típicos da sociedade de massas, normalmente caracterizados pela uniformidade, por oporem um grande número de pessoas desorganizadas frente a uma organização pública ou privada, e pela pequena expressão econômica de cada uma das causas individualmente considerada. Os desafios criados por essas duas situações são distintos, como são diferenciadas as características do processo destinado à tutela de cada espécie de direitos de interesse coletivo. Por isso vem se falando em uma dicotomia no processo coletivo, que separa a tutela de direitos coletivos, na qual se busca a efetividade dos direitos sociais indivisíveis, da tutela coletiva de direitos, pela qual se busca a proteção dos direitos individuais massificados em processos que reúnam e dêem solução uniforme a todos os conflitos em que se subdivide o conflito de massa.

A tutela dos direitos essencialmente coletivos teve de quebrar uma barreira muito importante na mentalidade dos juristas e aplicadores do direito, relacionada à própria admissibilidade dessa categoria jurídica. Tradicionalmente, a concepção de direito - uma situação de vantagem reconhecida por lei e, portanto, passível de proteção jurisdicional era estreitamente ligada à idéia de direito subjetivo, ou seja, de sua atribuição a um sujeito de direitos e obrigações (a "pessoa"). As utilidades insuscetíveis de apropriação individual, de outro lado, eram vistas como interesses que poderiam até ser relevantes, mas que não poderiam ser objeto de direitos e obrigações, ficando assim afastadas de qualquer proteção jurisdicional. Essa concepção cedeu com o aparecimento das Constituições do Estado Social do direito, que reconheceram os direitos coletivos nessa condição jurídica, nada 
obstante eles não pudessem ser atribuídos a pessoas e seu conteúdo fosse mais fluído do que os típicos direitos subjetivos. Do ponto de vista processual, as principais questões a serem vencidas foram aquelas relacionadas à legitimação para a causa, à tutela específica das obrigações de fazer (inspirada na injunction) ${ }^{16}$, e à redefinição do papel do juiz em ações caracterizadas pela fluidez do direito material em jogo.

Quanto à tutela coletiva dos direitos individuais, seu impacto sobre a teoria geral do direito não foi tão intenso, pois a estrutura desses direitos já era desde há muito tempo conhecida e admitida ${ }^{17}$. Como afirma LUIZ PAUlo DA SILVA ARAúJO FILHO, “o objeto natural da tutela dos direitos individuais homogêneos compreende exatamente os direitos subjetivos, direitos referidos a uma pessoa específica, particularmente subjetivados, e, por isso, não se pode deixar de respeitas suas características essenciais" ${ }^{\text {18 }}$. Por não constituírem algo essencialmente novo do ponto de vista conceitual, AluísIo GONÇALVES DE CASTRO MENDES afirma que os "direitos individuais são vistos, por vezes, como passageiros de segunda classe, ou até indesejáveis, dentro desse meio que é a tutela judicial coletiva"19, um estigma que o autor credita ao preconceito e resistência diante dos novos instrumentos processuais concebidos para sua proteção.

Quando se afirma que os interesses individuais homogêneos não constituem uma categoria nova, isto significa apenas que, do ponto de vista de sua estrutura, eles são assimiláveis ao instituto do direito subjetivo individual. Mas não podemos esquecer que a idéia de homogeneidade está ligada ao novo fenômeno da massificação e da dispersão das relações jurídicas na sociedade industrial, que descrevemos anteriormente. Do ponto de vista de seu conteúdo, portanto, os típicos direitos que podem se beneficiar da tutela coletiva são também "novos direitos", próprios da sociedade de massas. Tomem-se em

\footnotetext{
${ }^{16}$ Nesse sentido, LUIZ GUILHERME MARINONI afirma que "junto com a evolução da sociedade e o surgimento de novas situações de direito substancial, derivadas freqüentemente de regras infraconstitucionais de proteção de direitos fundamentais destinadas a impedir ou a impor condutas, tornouse cada dia mais importante a efetividade das denominadas 'obrigações de não-fazer e de fazer'. Aqui, passou a importar, mais do que nunca, a possibilidade de o juiz poder trabalhar com a coerção indireta, vale dizer, com meios de pressão sobre a vontade do demandado - especialmente com a multa. Tal necessidade se fez sentido em vários setores, sobretudo nos campos dos direitos difusos e coletivos, dos direitos dos consumidores e, em geral, dos direitos de natureza não patrimonial" (MARINONI, Luiz Guilherme. Técnica processual e tutela dos direitos. 2. ed. São Paulo: Ed. Revista dos Tribunais, 2008. p. 74).

${ }^{17}$ RICARDO DE BARROS LEONEL afirma, por isso, que "o tratamento processual coletivo conferido a esses interesses decorre da conveniência da aplicação a eles das técnicas de tutela coletiva. Sua implementação configura opção de política legislativa" (Manual do processo coletivo. São Paulo: Ed. Revista dos Tribunais, 2002. p. 108).

${ }^{18}$ ARAÚJO FILHO, Luiz Paulo da Silva. Ações coletivas: a tutela jurisdicional dos direitos individuais homogêneos. Rio de Janeiro: Forense, 2000. p. 102.

${ }^{19}$ MENDES, Aluisio Gonçalves de Castro. Ações coletivas no direito comparado e nacional. 2. ed. São Paulo: Ed. Revista dos tribunais, 2010. p. 226.
} 
consideração os direitos de crédito individual decorrentes de violação aos deveres de segurança adequada do produto fornecido no mercado de consumo, de propaganda verdadeira, ou de violação da livre concorrência, por danos ambientais, entre outros. Realmente, nada há de novo na estrutura desses direitos, pela qual o ofensor se torna ligado por um vínculo obrigacional a entregar determinada prestação ao ofendido, estabelecendo a lei posições de vantagem e subordinação recíprocas segundo a técnica do direito subjetivo. Mas as suas características particulares mais freqüentes - dispersão, baixa expressão econômica, desproporção de forças entre os pólos da relação jurídica recomendam fortemente que existam técnicas processuais adequadas para seu tratamento.

Do ponto de vista do processo, por outro lado, a situação se inverte na medida em que a tutela dos direitos individuais exige um procedimento mais complexo e sofisticado do que aquela própria aos direitos essencialmente coletivos, por duas ordens de razões. Por um lado é necessário conciliar as novas formas de tutela "molecularizadas" dos interesses da classe com as já existentes formas de proteção individual dos interesses de cada um de seus membros. Afinal, o Estado assegura a tutela jurisdicional dos direitos como uma garantia fundamental, de modo que quanto mais relevante for a utilidade individual do bem da vida que constitua o objeto do direito, mais delicada será a possibilidade de se permitir a um terceiro - o "autor ideológico" do processo coletivo - o ato de buscar sua tutela em um processo que envolva todo o grupo, com potencial prejuízo para o seu titular.

De outro lado, o tratamento coletivo de interesses pertencentes a um grande grupo de indivíduos tem de lidar com as limitações de complexidade que o processo jurisdicional tem a capacidade de suportar ${ }^{20}$. É um fato incontestável que a resolução de todos os pontos e questões necessários à definição dos direitos que cabem a toda uma coletividade de indivíduos consistiria em uma tarefa cujo cumprimento seria inviável no âmbito de um único processo, e isso deixa não mais do que duas alternativas para o legislador: ou bem o processo se limita a analisar determinados aspectos comuns aos direitos dos membros da classe, remetendo as questões diversificadas a processos complementares; ou então ele confere um tratamento global à massa de direitos, baseado em um simplificado juízo de probabilidade.

\footnotetext{
${ }^{20}$ Como ressalta CAMILO ZUFELATO, “a tutela coletiva de direitos individuais (homogêneos), realizada em nome da instrumentalidade e efetividade do processo, tem um limite de operacionabilidade, a partir do qual deverá ceder espaço para a manifestação das características inatas de um direito que é, em essência, individual e que somente será realizado de forma integral quando satisfizer um sujeito individual, seu único titular" (Coisa julgada coletiva. São Paulo: Saraiva, 2011. p. 68).
} 
Essa complexidade, entretanto, tende a ser compensada pelos efeitos benéficos que a tutela coletiva de direitos individuais pode proporcionar, como a economia de recursos do aparato jurisdicional, a uniformidade de tratamento a pessoas em situações equivalentes, e a viabilização da proteção judicial a direitos de diminuta repercussão econômica, que seriam privados de qualquer instrumento de tutela se não houvesse a possibilidade de uma ação coletiva. De acordo com uma adequada metáfora de ANDREA GIUSSANI, a ação civil coletiva do tipo ressarcitória pode ser pensada como um ônibus ("l'autobus della giustizia"), que venha a ser introduzido em uma cidade cujos habitantes estejam acostumados a andar somente de táxi ou automóvel individual. É verdade que o ônibus não é tão rápido e nem tão facilmente conduzido quanto o táxi (pelo que necessita de um motorista com habilitação especial), e muitos irão afirmar, nos primeiros dias, que o tamanho exacerbado do novo veículo somente teria criado embaraços que atrapalharam a locomoção dos demais automóveis. Mas gradualmente, algum tempo depois da introdução do novo transporte se terá percebido que a mobilidade urbana nessa cidade melhorou de maneira significativa e que, ainda que de forma um pouco menos cômoda, mais pessoas terão optado por adotar o transporte coletivo, seja em razão de seu custo unitário inferior, seja porque muitas delas eram antes desprovidas de recursos para andar de táxi ou adquirir um automóvel próprio ${ }^{21}$.

Da mesma maneira, o processo coletivo exige uma administração mais cuidadosa por parte do juiz, e sua condução é consideravelmente mais complexa do que a dos processos individuais. Isso o torna mais vagaroso e disputado, e quem decidisse comparálo com o processo individual, tomando-o em consideração de forma isolada, provavelmente só teria críticas a dirigir contra o novo instrumento. Seu valor, no entanto, se justificará na medida em que, observado a partir do plano mais geral da política de administração da justiça, ele se mostre capaz de proporcionar a economia de recursos judiciais, a efetividade da tutela a pretensões que não seriam buscadas pela via individual, e que ele possa, em médio prazo, desafogar um Judiciário congestionado por ações veiculadas por processos individuais.

${ }^{21}$ GIUSSANI, Andrea. Azioni colletive risarcitorie nel processo civile. Bologna: Il mulino, 2008. p. 76-77. 


\subsubsection{Repercussões políticas: participação pelo processo e acomodação das instituições}

$\mathrm{O}$ processo coletivo tem motivação e repercussões políticas inegáveis. $\mathrm{Na}$ proporção em que ele viabiliza que determinados direitos, até então excluídos de proteção jurídica por fatores de ordem prática, sejam objeto da tutela jurisdicional, ele afirma a autoridade do Estado para impor a ordem prevista por suas leis. É o aspecto destacado por AHARON BARAK, juiz da Suprema Corte israelense, para quem a ausência de regras de legitimidade processual para postular direitos de projeção coletiva cria "buracos negros" na ordem jurídica que em última instância ameaçam o próprio regime democrático ${ }^{22}$. Ao mesmo tempo, quando a legitimação é outorgada a entidades da sociedade civil, ele se converte em um instrumento de participação dos cidadãos na concretização de objetivos de política pública reconhecidos pela $\operatorname{lei}^{23}$. Nesse sentido é que se fala da presença de uma advocacia de interesse público (public law litigation) nos processos coletivos ${ }^{24}$.

\footnotetext{
22، The rules of standing are closely related to the principle of rule of law. Closing the doors of the court to a petitioner with no injury in fact who warns of a public body's unlawful action means giving the public body a free hand to act without fear of judicial review. The result is the creation of 'black holes' in which a legal norm exists but the public body is free to violate it without the possibility of judicial review. Such a situation may lead in the end in to a violation of the legal norm, undermining the rule of law and undermining democracy" (BARAK, Aharon. The judge in a democracy. Princeton: Princeton University Press, 2006. p. 194).

${ }^{23}$ RODOLFO DE CAMARGO MANCUSO associa o processo coletivo ao princípio de democracia participativa consagrado pela Constituição, afirmando que a partir dele se pressupõe a ampla da legitimação processual a diferentes representantes da sociedade: "o credenciamento outorgado a vários co-legitimados ativos para as ações de finalidade coletiva representa uma projeção, no plano judiciário, da diretriz constitucional da democracia participativa: à semelhança do apelo à integração da coletividade na boa gestão da coisa pública (plebiscito, referendo, audiências públicas, iniciativa popular de projetos de lei, participação em órgãos públicos colegiados de formação paritária), também essa participação é conclamada no plano judiciário: a $\mathrm{OAB}$, partido político, órgão sindical, no controle direito de constitucionalidade; o cidadão-eleitor, na ação popular; a entidade de classe, no mandado de segurança coletivo; a associação, na ação em defesa de seus aderentes; o Ministério Público, os entes políticos, as associações, os sindicatos, os órgãos públicos, nas diversas ações civis públicas; qualquer pessoa, física ou jurídica, no mandado de injunção" (A projetada participação eqüânime dos co-legitimados à propositura da ação civil pública: da previsão normativa à realidade forense. Revista dos Tribunais, São Paulo, n.796, p. 15, fev. 2002). Em linha parecida, ADA PELLEGRINI GRINOVER avalia o significado social e político da tutela de interesses coletivos, e registra o surgimento de "uma gestão participativa, como instrumento de racionalização do poder, que inaugura um novo tipo de descentralização, não mais limitada ao plano estatal (como descentralização político-administrativa), mas estendida ao plano social, com tarefas atribuídas aos corpos intermediários e às formações sociais, dotados de autonomia e funções específicas" (GRINOVER, Ada Pellegrini. Significado social, político e jurídico da tutela dos direitos difusos. In: A marcha do processo. Rio de Janeiro: Forense, 2000. p. p. 19).

${ }^{24}$ Como assinala CARLOS ALBERTO DE SALLES, "pretende-se com essa designação, distinguir aquelas lides nas quais a prestação jurisdicional recai sobre interesses individuais de outras, nas quais o objeto do processo é uma decisão sobre um interesse público. Observe-se que a oposição aqui estabelecida não é simétrica àquela entre direito privado e direito público, cuja base está, sobretudo, na definição de um campo de atuação do Estado. O público, no sentido pretendido neste trabalho, é definido não em contraste ao privado, mas ao individual, indicando aqueles interesses pertencentes à generalidade das pessoas"
} 
Uma das aplicações mais polêmicas do processo coletivo é a promoção de mudanças institucionais (institutional change) na sociedade. Essa faceta foi a mais evidente na aplicação que a class action norte-americana encontrou nos anos 60 e 70, quando era tipicamente utilizada com a finalidade de obter a tutela específica (injunctions) para acabar com a segregação racial em escolas, melhorar as condições de presídios, ou buscar direitos de previdência e assistência social ${ }^{25}$. A partir da década de 80 , no Brasil, a ação civil pública também passou a ser freqüentemente ajuizada com o objetivo de implementar direitos sociais ainda não concretizados por ausência de providências legislativas ou administrativas ${ }^{26}$. O exemplo típico de ação judicial orientada para essa finalidade é a que veicula interesses indivisíveis. Mas a ação civil coletiva que tem por objeto imediato a tutela de direitos individuais, por meio da estrutura clássica da pretensão subjetiva de direito material, também assume importância para a promoção da mudança institucional de maneira mediata, na medida em que a simples possibilidade de responsabilização de produtores ou do Estado por pequenas e múltiplas lesões que normalmente não seriam levadas a juízo, em razão de barreiras organizacionais ou econômicas, exerce uma força dissuasória (“deterrence") capaz de efetivamente alterar o equilíbrio do poder $^{27}$ nas relações em sociedade.

(Processo civil de interesse público, cit., p. 40). OWEN FISS, a esse respeito, afirma que a advocacia de interesse público é o objetivo político a ser perseguido pela política judiciária contemporânea, ao passo que as ações de classe não seriam mais nada do que os instrumentos criados para financiá-la: "In short, the class action could be viewed as a device to fund the private attorney general" (The political theory of the class action. In:___ The law as it could be. New York: New York University Press, 2003. p. 126).

${ }^{25}$ HENSLER, Deborah et al. Class action dilemmas: pursuing public goals for private gain. Santa Monica, California: Rand Institute for Civil Justice, 2000. p. 4-5. O caso emblemático desse período de desenvolvimento da class action foi o caso Brown vs. Board of Education of Topeka, em que a famosa "Warren Court" determinou ainda em 1954 que as escolas deveriam adotar providências para acabar com a segregação entre estudantes negros e brancos.

${ }^{26}$ Ainda na análise de CARLOS ALBERTO DE SALLES, “(...) ao definir o interesse preponderante, a atividade jurisdicional está decidindo sobre objetivos sociais em contraposição. Mais do que isso, à medida que a decisão incide sobre bens coletivos, realiza opções relacionadas com a alocação e a apropriação de recursos comuns. Nessa nova tarefa, a atividade judicial, forçosamente, estará deixando de realizar uma justiça apenas corretiva (ou retributiva), para incidir num campo de justiça distributiva, ligada à atribuição individual ou coletiva de recursos comuns" (Processo civil de interesse público, cit., p. 56). Por isso, ELTON VENTURI vem a afirmar um papel central do processo na conformação democrática da sociedade contemporânea: "a tutela coletiva assume, desta forma, uma função extraordinária, que exorbita o plano jurídico e social, sendo indispensável à conformação política do Estado Democrático de Direito. A efetiva operacionalidade do sistema das ações coletivas passa a ser encarada não mais como mera consequiência, mas como condição de existência e prevalência da democracia, diante das possibilidades que gera em relação ao rompimento das inúmeras barreiras opostas ao acesso à justiça, mediante o emprego de técnicas diferenciadas de legitimação ativa e de extensão subjetiva da eficácia da coisa julgada" (Processo civil coletivo: a tutela dos interesses difusos, coletivos e individuais homogêneos no Brasil. São Paulo: Malheiros Ed., 2007. p. 102).

${ }^{27}$ "While on the surface the adoption of a class action procedure may appear to be a technical matter of interest only to the lawyers, the social, economical, and political consequences of permitting class actions are potentially vast. (...) Taken together, these consequences have enormous potential to deter institutional and corporate wrongdoing and to shift the balance of power between citizens and their governments, 
De outro lado, os instrumentos do processo coletivo são relativamente novos e as suas aplicações assumem muitas vezes um caráter experimental para as partes, juízes e advogados. Isso faz com que ele seja naturalmente aberto a servir como instrumento para a prática de abusos e injustiças ${ }^{28}$, o que é um efeito colateral indesejado, mas natural ao longo do desenvolvimento da prática do contencioso coletivo, ao menos enquanto suas possibilidades e limites não se tornarem claros para todos. Evidentemente, setores da sociedade que estavam habituados a se subtrair da observância das leis sem sofrer quaisquer conseqüências buscaram se organizar contra as reformas associadas à tutela coletiva, e os excessos ocorridos sempre foram explorados na arena política com a finalidade de restringir esses novos e poderosos instrumentos de tutela jurisdicional.

Por tudo isso, a história das ações coletivas é marcada por avanços e retrocessos, que gradualmente vem trazendo equilíbrio entra as garantias constitucionais do processo e o acesso à justiça dos novos direitos. Verificaram-se períodos de liberalismo e experimentação em que as garantias constitucionais foram testadas até os seus limites; sucedidos, então, por temperamentos conservadores, muitas vezes inspirados pela justa desconfiança despertada pelas repercussões de processos mal conduzidos, mas outras por uma malícia praticamente declarada de setores acostumados à zona de conforto em que as pequenas lesões de direito são inacessíveis à tutela jurídica (os “mass wrongdoers”). Assim como nos Estados Unidos o primeiro impulso de desenvolvimento da class action nas décadas de 60 e 70 sofreu um grande revés com a decisão de Eisen vs. Carlile pela Suprema Corte em 1974, e sua posterior expansão nos casos de danos de massa (mass tort litigation) das décadas de 80 e $90^{29}$ foi seguida pelas medidas restritivas do Class Action Fairness $A c t^{30}$; no Brasil se observaram diversas medidas restritivas às ações coletivas que

employees and employers, and consumers and manufacturers and service providers" (HENSLER, Deborah; HODGES, Christopher; TULIBACKA, Magdalena (Eds.). The globalization of class actions: an overview, cit., p. 8).

${ }^{28}$ A referência a abusos por parte do ajuizamento de ações coletivas, justificado por noções vagas de interesse público, pode ser encontrada no artigo de ROGÉRIO DE LAURIA TUCCI, Ação civil pública: abusiva utilização pelo Ministério Público e distorção pelo Poder Judiciário. In: WALD, Arnoldo. Aspectos polêmicos da ação civil pública. 2. ed. São Paulo: Saraiva, 2007. p. 355-392.

${ }^{29}$ A expansão da class action nesse período é relatada por ADA PELLEGRINI GRINOVER: “(...) vale notar que as ações de classe norte-americanas, que haviam declinado em número na década passada, ganharam novo e redobrado impulso, exatamente no campo das reparações individuais, por força dos denominados mass tort cases: assim ocorreu com as vítimas do asbesto, que já eram em 1990 mais de 887 mil e cujas pretensões foram freqüentemente agrupadas perante tribunais federais e estaduais" (GRINOVER, Ada Pellegrini et al. Código Brasileiro de Defesa do Consumidor comentado pelos autores do anteprojeto. 8. ed. Rio de Janeiro: Forense, 2005. p. 858).

${ }^{30}$ Como aponta LUIS ROBERTO BARROSO, "em fevereiro de 2005, foi aprovada lei federal denominada Class Action Fairness Act of 2005, com o propósito declarado de coibir abusos no emprego das ações de classe. A lei, de caráter claramente restritivo, institui regras de limitação ao recebimento de honorários em 
acabam de ser reguladas pelo Código de Defesa do Consumidor, como a assim chamada limitação territorial da coisa julgada, a restrição da sentença genérica aos filiados da associação autora etc. ${ }^{31}$ que, muitas vezes reagindo a distorções verificadas na prática do processo, visaram a regulamentar o processo coletivo dentro de balizas mais seguras e conformes ao devido processo legal. Esse padrão de marchas e contramarchas é característico da evolução do processo coletivo, e pode ser considerado um reflexo da acomodação institucional que decorre de suas acentuadas repercussões políticas. O debate doutrinário em torno desse ramo do processo - inserido neste ambiente conflituoso - é marcado também por um forte componente ideológico ${ }^{32}$, entendido como aquele que pretende influir na realidade (em qualquer dos dois sentidos) em lugar de apenas descrevê-la. Como foi observado em um ensaio de ARTHUR MILLER, nele muitas vezes se busca enxergar cavaleiros em armaduras brilhantes ou monstros abomináveis ${ }^{33}$, quando na realidade o processo coletivo é uma conseqüência necessária das alterações por que passam a própria sociedade e o direito a partir da segunda metade do século XX. Assim, é inútil combater a sua existência, e contraproducente ignorar os seus riscos e deficiências: cumpre estudá-lo, para que se possam desenvolver instrumentos eficazes e seguros de tutela dos novos direitos que caracterizam a sociedade contemporânea.

\subsection{O sistema brasileiro de tutela coletiva de direitos}

As ações coletivas, no Brasil, surgiram em um primeiro momento pela via da criatividade da jurisprudência em adaptar institutos já existentes na ordem processual, o que é um desdobramento freqüente em países nos quais a tutela coletiva não foi regulamentada por lei. Posteriormente, e de forma mais intensa no período compreendido

determinados tipos de acordo (coupon settlements), de proteção contra perdas pelos membros da classe e de proteção contra discriminação dos membros da classe em razão do Estado de seu domicílio, além de impor exigência de notificação a autoridades estaduais e federais de qualquer acordo proposto". (A proteção coletiva dos direitos no Brasil e alguns aspectos da class action norte-americana. Revista Forense, Rio de Janeiro, v. 101, n. 381, p. 103-19, set./out. 2005).

${ }^{31}$ Em tom acentuadamente crítico, vide GRINOVER, Ada Pellegrini. A ação civil pública refém do autoritarismo. Revista de Processo, São Paulo, n. 96, p. 28-36, out./dez. 1999, e as observações feitas no Código Brasileiro de Defesa do Consumidor comentado pelos autores do anteprojeto, cit., p. 919-924.

${ }^{32}$ Anota ANTONIO GIDI que "as ações coletivas, como instrumento poderoso, de profundo impacto social, é uma área do direito processual extremamente sensível às concepções ideológicas do aplicador do direito" ( $A$ class action como instrumento de tutela coletiva dos direitos: as ações coletivas em uma perspectiva comparada. São Paulo: Ed. Revista dos Tribunais, 2007. p. 39).

${ }^{33}$ MILLER, Arthur. Of Frankenstein monsters and shining knights: myth, reality, and the 'class action problem'. Harvard Law Review, v. 92, p. 664-694, Jan. 1979. 
entre meados da década de 1980 e início da década de 1990, em que foram aprovadas as leis da ação civil pública e o Código de Defesa do Consumidor, nosso país contou com a elaboração de uma legislação específica que pretendeu regulamentar um sistema de tutela coletiva inspirado nas ações de classe norte-americanas, mas adaptado aos princípios de direito de raiz romano-germânica em que se insere nossa tradição jurídica.

\subsubsection{Antecedentes na tutela coletiva: da ação popular à ação civil pública}

Como a tutela coletiva decorre de necessidades práticas, geradas pela mudança do perfil dos conflitos que emergiram da sociedade no século passado, freqüentemente as legislações dos diversos países que regulamentaram o processo coletivo seguiram um movimento já iniciado pela prática judicial. E nesse sentido, de acordo com o registro de BARBOSA MOREIRA, a história da tutela coletiva brasileira iniciou-se conforme os tribunais passaram a aceitar a tradicional ação popular, pela qual a qualquer cidadão é conferida a legitimidade de postular a anulação de atos lesivos ao patrimônio público - como meio de defesa de interesses urbanísticos e ambientais $^{34}$, uma finalidade não prevista originariamente pelo texto da Lei n. 4.717/65. Essa construção foi possível porque o legislador, ao regulamentar o art. 141, §38, da Constituição de 1946, definiu em termos bastante amplos a expressão "patrimônio público", para nele incluir os "bens e direitos de valor econômico, artístico, estético ou histórico". A inovação jurisprudencial consistiu em aplicar a lei para assegurar bens de interesse coletivo que não tivessem propriamente valor artístico, estético ou histórico, mas que ainda assim dissessem respeito à manutenção de níveis qualitativos de vida da população, abrindo-se assim as portas para uma tutela mais ampla dos direitos difusos ${ }^{35}$. Tendo prática da tutela coletiva se iniciado pelo caminho da ação popular, não é de se estranhar que muitas das suas soluções, notadamente no que diz respeito à coisa julgada, erga omnes e secundum eventum litis $^{36}$, viessem a ser aproveitadas pela legislação posterior.

\footnotetext{
${ }^{34}$ BARBOSA MOREIRA, José Carlos. A ação popular do direito brasileiro como instrumento de tutela jurisdicional dos chamados "interesses difusos". In:___. Temas de direito processual: $1^{\text {a }}$ série. 2. ed. São Paulo: Saraiva, 1988. p. 116. O autor faz referência a ações populares ajuizadas para impedir a construção de aeroporto em Brasília, o aterro parcial da Lagoa Rodrigo de Freitas, a demolição de edifício de valor arquitetônico em São Paulo para a instalação de estação do Metropolitano, entre outros.

${ }^{35}$ BARBOSA MOREIRA, José Carlos. A ação popular como instrumento de tutela dos direitos difusos, cit., p. 116-117.

${ }^{36}$ Lei $n^{\circ} 4.717 / 65$, artigo 18 .
} 
Em 1985, a ação civil pública foi regulamentada pela Lei n. 7.347, de 24 de julho, que inaugurou um procedimento de iniciativa do Ministério Público, das pessoas de direito público ou de associações civis que contemplava a ação de responsabilidade por danos causados ao meio ambiente, ao consumidor, a bens de valor histórico, turístico e paisagístico, e à ordem urbanística. Muito embora fossem taxativas as hipóteses de cabimento da ação civil pública, a lei da ação civil pública representou um grande progresso para a tutela coletiva, chegando-se a dizer que se tratou de um divisor de águas na matéria ${ }^{37}$, ao inaugurar as técnicas de legitimação ativa concorrente e disjuntiva entre diversas entidades representativas da sociedade, a da execução específica de obrigações de fazer (inspirada nas injunctions do direito norte-americano), bem como ao instituir os mecanismos do inquérito civil público a cargo do Ministério Público e a execução em prol de um fundo para recomposição dos interesses lesados.

Se até esse ponto a tutela coletiva podia ainda ser considerada uma novidade promissora, mas de futuro incerto, pode se dizer que a Constituição de 1988 depositou nela grande parte de suas esperanças para a institucionalização de um processo civil mais efetivo. Em tal sentido, o texto constitucional vigente reconheceu um amplo cartel de direitos sociais e coletivos; alargou o âmbito de cabimento da ação popular; previu o mandado de segurança coletivo e o mandado de injunção; e reconheceu expressamente a legitimação de partidos políticos, sindicatos, associações civis e do Ministério Público para demandar no interesse de grupos sociais. Estava aberto o campo, assim, para que o legislador desenvolvesse um sistema amplo e integrado de tutela coletiva, que veio a gravitar em torno de um moderno Código de Defesa do Consumidor que seria aprovado dois anos depois.

\subsubsection{O Código de Defesa do Consumidor e a "ação de classe brasileira"}

Após a Constituição de 1988, o Código de Defesa do Consumidor (Lei n. 8.078, de 11 de setembro de 1990) veio ao mundo como o mais importante documento legislativo de tutela coletiva no direito brasileiro, e nessa posição ele persiste até os dias correntes. Antes dele, diversas leis haviam previsto instrumentos de tutela coletiva em matérias específicas,

\footnotetext{
${ }^{37}$ ALMEIDA, Gregório Assagra de. Direito processual coletivo brasileiro: um novo ramo do direito processual: princípios, regras interpretativas e a problemática de sua interpretação e aplicação. São Paulo: Saraiva, 2003. p. 333.
} 
tais como os interesses de portadores de deficiências (Lei ${ }^{\circ} 7.853 / 89$ ), de investidores no mercado de valores mobiliários (Lei ${ }^{\circ}$ 7.913/89), e de crianças e adolescentes (Lei n. ${ }^{\circ}$ $8.069 / 90)$.

Mas o Título III do Código de Defesa do Consumidor, que abrange seus artigos 81 a 104, viria a se destacar por regulamentar de maneira ampla a tutela coletiva no processo civil, integrando-se à disciplina da lei da ação civil pública e erigindo-se em um verdadeiro “Código de Processo Civil Coletivo". Ele trouxe importantes modificações para o sistema de tutela coletiva, a começar por eliminar o critério de taxatividade dos bens passíveis de $\operatorname{tutela}^{38}$. Mantendo as regras de legitimação da lei da ação civil pública, o Código procedeu a um importante trabalho de sistematização, definindo e classificando os interesses passíveis de proteção coletiva, e atribuindo a cada espécie regras peculiares de processamento, litispendência, competência e coisa julgada. O Código regulamentou a defesa dos interesses essencialmente coletivos, classificando-os em difusos e coletivos em sentido estrito. Ambos são definidos pela lei como transindividuais, "de natureza indivisível", com a diferença de que os interesses coletivos pressupõem uma relação jurídica-base anterior entre a coletividade interessada, enquanto os interesses difusos dizem respeito a pessoas indeterminadas, ligadas por circunstâncias de fato (artigo 81, incisos I e II, da Lei $n^{\circ}$ 8.078/90).

O que o Código de Defesa do Consumidor trouxe de realmente novo, contudo, foi a possibilidade da tutela de direitos individuais por meio de um processo coletivo. E ela foi regulamentada a partir da definição de uma nova categoria de direitos, que a lei chamou de "individuais homogêneos", definidos sucintamente como aqueles "de origem comum" (art. 81, inciso III).

Para a sua defesa foi previsto - ao lado de outros instrumentos - um procedimento especial de "ação civil coletiva de responsabilidade pelos danos individualmente sofridos", que recentemente veio a ser chamada de "ação de classe brasileira" 39 , muito embora em doutrina já se tenha chamado a atenção para que o modelo da ação coletiva ressarcitória que vem sendo adotado em países da tradição continental de civil law, embora se aproxime

\footnotetext{
${ }^{38}$ Há de se anotar, contudo, que posteriormente sobrevieram restrições pontuais à tutela coletiva, especialmente em face do poder público. A propósito, vide o item 3.3.1, abaixo.

${ }^{39}$ GRINOVER, Ada Pellegrini. Da class action for damages à ação de classe brasileira: os requisitos de admissibilidade. Revista Forense, Rio de Janeiro, n. 352, p. 1-14, set./dez. 2000.
} 
da ação de classe, consiste em um instrumento mais rígido e limitado ${ }^{40}$. Em linhas gerais, nos termos da sistematização proposta por TEORI ALBINO ZAVASCKI, o procedimento especial da ação coletiva se distingue por três características essenciais: a legitimação extraordinária de um substituto processual para atuar no interesse da classe na fase coletiva; a repartição da atividade cognitiva segundo a natureza das questões a serem analisadas, com a resolução do núcleo de homogeneidade comum à classe em uma ação coletiva e posterior decisão das questões particulares em ações individuais de cumprimento a serem promovidas por cada interessado; e a coisa julgada erga omnes e secundum eventum litis, que se estende a toda a classe, apenas para beneficiar seus membros, mas sem prejudicar as suas ações individuais ${ }^{41}$.

Atualmente, portanto, o Código de Defesa do Consumidor é o marco legislativo central do micro-sistema de tutela coletiva brasileiro, integrado também pelos demais diplomas citados neste breve histórico. Mas antes de passarmos ao exame das principais características do procedimento especial que distingue a ação coletiva, cabe fazer menção ao fato de que os vinte anos de experiência com o instrumento evidenciaram algumas limitações e, com o tempo, inspiraram diversos projetos de reforma por parte da doutrina: de início, o Código-Modelo de Processos Coletivos para a Ibero-América aprovado pelo Instituto Ibero-Americano de Direito Processual nas XIX Jornadas de Direito Processual de 2004, em Caracas (Venezuela). Posteriormente, foram desenvolvidos anteprojetos por cursos de pós-graduação no âmbito da Universidade de São Paulo e, em trabalho conjunto, pela Universidade do Estado do Rio de Janeiro e pela Universidade Estácio de $\mathrm{Sá}^{42}$. As discussões travadas em torno desses projetos da Academia acabaram inspirando o Projeto de Lei $n^{\circ} 5.139 / 09$, encaminhado ao Congresso Nacional pelo Ministério da Justiça, que visava a instituir um Código de Processo Coletivo.

\footnotetext{
${ }^{40}$ Nesse sentido, os comentários de MARCO BONA em torno da azione collettiva risarcitoria italiana (CONSOLO, Claudio; BONA, Marco; BUZZELLI, Paolo. Obiettivo class action: l'azione colletiva risarcitoria. Lavis: Wolters Kluwer, 2008. p. 59-60), de aplicação ainda mais restrita que a brasileira pela adoção do critério do opt-in na composição da classe e da restrição à matéria de direito do consumo. Em comum com a nossa ação civil coletiva, o modelo italiano apresenta a ausência de incentivo econômico para a organização da ação coletiva por parte de advogados especializados (a "entrepeneurial bar" que deu verdadeiro impulso à class action estadunidense), a falta de poderes do juiz do caso concreto para definir a forma mais conveniente de tutela a ser prestada aos interesses em discussão, a ausência de uma decisão de certificação ou análise da adequação da representatividade do autor coletivo, e a falta de previsão de "punitive damages". Não se está aqui a dizer que o modelo norte-americano seja em todos os aspectos o mais adequado, mas apenas indicando que o modelo da ação civil coletiva não se confunde inteiramente com o da class action.

${ }^{41}$ ZAVASCKI, Teori. Processo coletivo: tutela de direitos coletivos e tutela coletiva de direitos. 4. ed. São Paulo: Ed. Revista dos Tribunais, 2009. p. 151-160.

${ }^{42}$ ALMEIDA, Gregório Assagra de. Codificação do direito processual coletivo brasileiro. Belo Horizonte, Del Rey, 2007, especialmente p. 86-125.
} 
Esse projeto, que não se limitava a aperfeiçoar as deficiências do modelo atual, mas pretendia introduzir profundas modificações em nosso modelo de tutela coletiva, foi rejeitado em caráter terminativo pela Comissão de Constituição e Justiça da Câmara dos Deputados, que aprovou voto do relator, deputado federal JosÉ CARLOS ALELUIA, em que se manifestava preocupação com a insegurança jurídica e com a desigualdade de tratamento entre as partes, além de considerar ineficaz a sistemática proposta para diminuir o número de processos a respeito de um mesmo assunto de projeção coletiva ${ }^{43}$. Embora ainda penda, à data em que se escreve esta dissertação, recurso do deputado ANTONIO CARlos Biscaia para que a matéria seja levada ao Plenário, a aprovação do Código tornou-se bastante incerta, especialmente tendo em conta os supervenientes debates em torno de um novo Código de Processo Civil que traz a proposta alternativa de um “incidente de coletivização" destinado à tutela dos direitos de massa.

Considerada a importância dos debates que cercaram a tramitação desse projeto junto ao Poder Legislativo, contudo, ao longo deste trabalho ocasionalmente faremos remissão às soluções por ele propostas ao analisarmos os principais "pontos de estrangulamento" da tutela coletiva de direitos no panorama atual.

\subsection{A reorganização da atividade cognitiva na tutela dos interesses individuais homogêneos: a simultânea reunião e fragmentação das lides individuais}

A característica mais marcante do procedimento especial destinado à tutela coletiva dos danos individualmente sofridos está no modo como o legislador reorganizou a cognição, pelo juiz, dos pontos e questões relacionados à lide coletiva, em comparação com o modelo do processo individual. Isso foi feito, de maneira realmente engenhosa, pela combinação de duas técnicas: primeiro, a reunião das pretensões individuais de todos os membros da classe para julgamento conjunto em um processo coletivo, e, então, a cisão do julgamento de cada uma delas em processos distintos e sucessivos, de modo a que o

\footnotetext{
${ }^{43} \mathrm{O}$ parágrafo final do voto do deputado federal JOSÉ CARLOS ALELUIA concluiu que "em suma, a proposição não resolve os problemas do modelo atual das ações civis públicas, gera insegurança jurídica em escala inimaginável, fomenta a ida irresponsável a juízo para a defesa de interesses coletivos sem qualquer garantia de que esses interesses estejam sendo bem representados, e expõe toda a economia, toda a sociedade e todos os indivíduos ao risco de se tornarem réus numa ação em que serão tratados como párias, do começo ao seu longínquo fim" (Diário da Câmara dos Deputados de 29.04.10, p. 3).
} 
tratamento coletivo se limitasse à parte comum das diversas pretensões, cujos aspectos particulares são remetidos a processos específicos.

Assim, a ação civil coletiva se constitui como um procedimento extremamente sofisticado, em que não coincidem integralmente as pretensões deduzidas em juízo e o objeto do processo. Pois enquanto a tutela jurídica pretendida é a reparação individualmente devida a cada indivíduo substituído em juízo, o processo se limita a examinar as questões comuns a todos eles. Evidentemente, as ações individuais desempenham um indispensável papel complementar, pois sem elas não se completa a tutela jurídica prometida pelo Estado. Dada essa íntima relação entre os dois tipos de processo, que se voltam à solução de uma mesma pretensão, é possível considerá-los como partes que integram um sistema relativamente autônomo.

A inspiração para a repartição da atividade cognitiva em dois processos distintos, um de natureza coletiva e outros individuais, pode ser encontrada em ao menos duas fontes. A primeira delas é o dissídio coletivo do direito trabalhista, citado por ADA PELlegrini GRINOVER como origem da técnica empregada pelo Código de Defesa do Consumidor $^{44}$, que dá origem a direitos individuais que devem ser pleiteados por ações de cumprimento de cada trabalhador. A outra fonte inspiradora da técnica está na class action norte-americana, que exerceu uma reconhecida influência na concepção da ação civil coletiva brasileira. A divisão da cognição em processos distintos é uma solução eminentemente prática para lidar com a complexidade dos casos de lesão de massa, estreitando o campo de cognição em cada um dos julgamentos para que a decisão da causa não fique inviabilizada pelo número e pela diversidade de pontos pertinentes à pretensão reparatória. Nos termos das Federal Rules of Civil Procedure de 1966, assim, o juiz tem a faculdade de "bifurcar" o processo, dividindo a análise das questões de fato em dois ou mais processos distintos ${ }^{45}$. A previsão para esse tipo de determinação se encontra na Rule

\footnotetext{
${ }^{44}$ GRINOVER, Ada Pellegrini et al. Código Brasileiro de Defesa do Consumidor comentado pelos autores do anteprojeto, cit., p. 886.

${ }^{45}$ Como anota CÁSSIO SCARPINELLA BUENO ao estudar as class actions, "uma outra fórmula para individualização do julgamento envolve uma bifurcação deste dano. A primeira trata somente da questão da existência da responsabilidade, no qual são usadas as mesmas técnicas do julgamento tradicional. A segunda - que tem cabida somente diante da declaração da responsabilidade - destina-se à quantificação dos danos, seja envolvendo "minijulgamentos" para apuração de danos individuais, que bem se amolda à opção legislativa nacional, ou um procedimento genérico destinado a calcular os danos referentes à classe como um todo." (BUENO, Cássio Scarpinella. As class actions norte-americanas e as ações coletivas brasileiras: pontos para uma reflexão conjunta. Revista de Processo, São Paulo, n. 82, p. 92-151, abr./jun. 1996).
} 
42, (b), que lhe permite instituir um julgamento separado ("separate trial") de quaisquer questões por motivos de conveniência, prejudicialidade, celeridade ou economia ${ }^{46}$.

Muito embora a separação das questões para julgamento seja possível também nos processos individuais, trata-se de uma medida de particular interesse para as ações que envolvem questões de fato comuns a uma classe. CRAIG JONES, professor da University of British Columbia, ao escrever sobre a class action canadense, afirma que as grandes dificuldades geradas pela reunião das pretensões da classe em um único processo derivam da diversidade de conteúdo das pretensões individuais. Quando a ação coletiva impõe um tratamento único para toda a classe, a despeito da diversidade de conteúdo dos direitos de seus membros, haverá a possibilidade de que o julgamento se mostre injusto tanto em face do réu como dos indivíduos representados. Para evitar esses riscos, a divisão da ação coletiva em um processo voltado às questões comuns, a ser posteriormente complementado por ações ou outros meios de composição individuais, elimina os riscos da desigualdade de tratamento e ao mesmo tempo se mostra suficiente para nivelar o desequilíbrio entre as partes, pois é justamente no enfrentamento das questões comuns que o litigante habitual obtém a sua economia de escala ${ }^{47}$.

Em que pese essa evidente vantagem, é interessante notar que a repartição da atividade cognitiva em diferentes processos sofre críticas nos Estados Unidos, na medida em que os julgamentos feitos pelo júri se tornariam mais frios - um "ambiente de laboratório" - na medida em que se confere tratamento isolado às questões comuns. Isso conduziria a uma indesejável disparidade de resultados entre as ações bifurcadas e as ações que examinam todos os aspectos do caso, pois nestas é possível atrair a empatia do júri pela apresentação dos danos pessoais sofridos juntamente com as questões relacionadas à

\footnotetext{
${ }^{46}$ Eis o texto da Regra 42, (b): "For convenience, to avoid prejudice, or to expedite and economize, the court may order a separate trial of one or more separate issues, claims, crossclaims, counterclaims, or third party claims. When ordering a separate trial, the court must preserve any federal right to a jury trial".

${ }^{47}$ "Claim value diversity within the class, as briefly described above, tends to raise the greatest concerns over fairness in an all-or-nothing aggregation system; the greater the flexibility in their systems accomodation of individual issues while preserving single adjudication of common issues, the less likely are high-value claimants to be concerned - after all, on the common issues, they too enjoy the advantages offered by scale economy, even if not to the same extent as those with lower-value claims. All of the arguments that favour aggregation of individual lawsuits into class actions apply with respect to common issues. Since it is precisely with respect to common issues that the defendant enjoys a significant advantage of economic scale, it is these questions which, when heard in a single action, will best allow the plaintiffs to adequately compete." (JONES, Craig. Theory of class actions: optimal aggregation in mass tort litigation. Toronto: Irwin Law, 2003. p. 86).
} 
responsabilidade ${ }^{48}$. Esse risco, no entanto, não parece aplicável ao procedimento brasileiro, em que todas as fases do processo são conduzidas perante um juiz togado.

Desse modo, um conjunto de conflitos individuais, marcados pela uniformidade, é reunido para decisão conjunta, mas isso se faz apenas até onde vão os pontos de interesse comum. Assim, a cognição resta incompleta ao fim do primeiro processo, pois tudo aquilo que tem de interesse apenas particular a cada indivíduo lhe é alheio. Por tal razão, e sob uma diferente perspectiva, a resolução de cada uma das pretensões individuais é seccionada em processos distintos, de modo que a decisão judicial sobre cada situação em concreto somente é alcançada ao fim de dois processos, em lugar de um. Dessa forma, o procedimento da ação civil coletiva se revela como um elaborado fruto de engenharia processual: a fim de assegurar uniformidade de tratamento, economia processual, e nivelar o equilíbrio de forças entre as partes, as pretensões são reunidas em um único processo, que é uma técnica similar à do litisconsórcio, por exemplo, mas diante do número de indivíduos interessados, determina-se que apenas uma parte substituirá a todos no processo. Mas o projeto somente se completa com a limitação horizontal da cognição do juiz, que é aprofundada, mas limita-se aos pontos compartilhados por toda a classe. Tratase de cognição exauriente mas parcial ${ }^{49}$, tanto na ação coletiva em si como nos processos complementares que lhe seguem.

Essas simples alterações no modo de dispor o tempo e o local de análise das diversas questões necessárias ao reconhecimento dos direitos individuais homogêneos

\footnotetext{
${ }^{48} \mathrm{O}$ caso que a doutrina cita como paradigma desse risco foi o contencioso em torno da alegação de malformações fetais causadas pelo Bendectin, uma droga para enjôos produzida pelo laboratório Merrell Dow Pharmaceuticals Inc. Nesse caso houve uma ação de classe, em que o procedimento foi bifurcado e o júri afastou a responsabilidade do réu por ausência de causalidade. Entretanto, algumas das vítimas exerceram o direito de promover ações autônomas (opt-out), e ao levarem a integralidade do caso ao conhecimento dos júris, obtiveram a condenação do laboratório, em um resultado oposto ao atingido na ação coletiva (MULLENIX, Linda S. Mass tort litigation: cases and materials. 2. ed. St. Paul: West Publishing Co., 2008. p. 828-830; TIDMARSH, Jay; TRANSGRUD, Roger. Complex litigation: problems in advanced civil procedure. New York: Foundation Press, 2002. p. 258-262). RICHARD MARCUS e EDWARD SHERMAN mencionam que pesquisas indicaram que, em ações de reparação de danos pessoais, o tratamento separado da questão da responsabilidade (liability) tende a duplicar as chances de vitória do réu. (Complex litigation: cases and materials on advanced civil procedure. Thomson-West, 2004. p. 766).

${ }^{49}$ Sobre as dimensões da cognição judicial, e suas possíveis combinações em sede de procedimentos especiais, é obra de referência a monografia de KAZUO WATANABE, Da cognição no processo civil. 2. ed. São Paulo: Central de Publicações Jurídicas, 1999. p. 109 e ss. Escreve ele, a respeito da técnica utilizada na ação civil coletiva, que "a característica dessa forma de cognição está na limitação no tocante à amplitude, mas ilimitação quanto à profundidade da cognição voltada ao objeto cognoscível. (...) Ao estabelecer limitações, o legislador leva em conta a natureza do direito ou da pretensão material, a sua disciplina no plano substancial (às vezes contida em dispositivos legais localizadas em estatuto processual), ou volta pela proibição de controvérsia sobre alguma questão no processo, com o objetivo de simplificá-lo e torná-lo mais célere, mas com a ressalva do direito de questioná-la em ação autônoma" (Da cognição no processo civil, cit., p. 117). Esse último objetivo, precisamente, é o que inspirou o legislador de 1990 a adotar a técnica da limitação horizontal da cognição nas ações civis coletivas.
} 
representaram um aperfeiçoamento significativo do ponto de vista técnico-processual. Antes da Lei n. 8.078/90, a única opção disponível para a tutela de danos causados a uma coletividade - se a dimensão econômica dos interesses fizesse viável essa escolha - era a propositura de diversas demandas, a serem processadas em paralelo, cada uma delas dedicada a resolver tanto as questões comuns a toda a coletividade como aquelas particulares de cada autor, segundo a estrutura do processo tradicional, porque a distinção é irrelevante para a configuração do suporte fático do qual derivariam os direitos individuais reclamados em juízo. Assim, todos esses processos individuais se dedicariam a resolver as mesmas questões de fato e direito compartilhadas pelo grupo de interessados, e o modo como elas fossem tratadas em cada um deles não se comunicaria aos demais, sem que nada prevenisse que a conclusão alcançada sobre elas em processos distintos fossem contrastantes entre si. Os inconvenientes que se identificam nesse sistema são a repetição de trabalho, especialmente gravosa quando a causa exige prova técnica; e a possibilidade de decisões contraditórias para casos muito assemelhados entre si, distorção que pode não resultar em nenhum problema prático, mas que não deixa de comprometer em algum nível a legitimidade da jurisdição estatal.

O fascínio exercido pela ação civil coletiva, exemplo da capacidade de adaptação do procedimento à especialidade da causa, está no modo como o legislador alterou radicalmente a estrutura do processo, seccionando seu objeto e reunindo apenas a parcela de interesse comum para decisão conjunta, de modo a que sejam atingidos ao final do processo exatamente os mesmos resultados materiais que a tutela individual proporcionaria. Como benefício para a sociedade, a decisão deve ser capaz de proporcionar maior economia de recursos das partes e do Estado, uniformidade de julgamentos, e desestímulo a práticas ilícitas de pequena repercussão individual ${ }^{50}$.

\footnotetext{
${ }^{50}$ Nas palavras de RODOLFO DE CAMARGO MANCUSO, “(...) a ação em prol dos interesses individuais homogêneos apresenta rito diferenciado, compactado, por conta da pragmática finalidade de se chegar a uma condenação genérica do responsável pelos danos infligidos à coletividade de lesados e/ou sucessores, seguindo-se oportunamente a liqüidação a execução, esta promovida 'pela vítima e seus sucessores, assim como pelos legitimados de que trata o art. 82', conforme dispõe o art. 97 do CDC." (Jurisdição coletiva e coisa julgada: teoria geral das ações coletivas. 2. ed. São Paulo: Ed. Revista dos Tribunais, 2007. p. 191).
} 


\subsubsection{O objeto da ação coletiva e o conceito processual de homogeneidade}

Para darmos início à análise da ação coletiva para a defesa de interesses individuais homogêneos, temos de identificar antes de tudo qual a condição específica de admissibilidade em que se faz adequada a tutela jurisdicional a ser prestada sob as formas diferenciadas de seu procedimento. Nessa linha, a ação civil de responsabilidade pelos danos individualmente sofridos se destina a tutela de interesses individuais homogêneos, que o Código de Defesa do Consumidor definiu como aqueles "decorrentes de origem comum" (art. 81, inciso III). A simplicidade da expressão oculta, contudo, nuances que devem ser explicitadas para que o sistema de tutela coletiva se torne funcional.

Como vimos no item 2.1.2, os direitos individuais homogêneos não constituem uma categoria jurídica nova. Trata-se dos mesmos direitos subjetivos individuais, reunidos sob um conceito puramente instrumental, destinado a viabilizar a resolução concentrada de pontos comuns de fato e direito em um único processo coletivo. Daí a oportuna observação de BARBOSA MOREIRA, que os considera como direitos acidentalmente coletivos ${ }^{51}$, em oposição aos interesses essencialmente coletivos que o Código de Defesa do Consumidor contemplou nos dois primeiros incisos do artigo 81 (os interesses difusos e coletivos se definem como interesses de natureza indivisível, no sentido de que é impossível a sua cisão e atribuição de quotas a indivíduos) ${ }^{52}$. Assim, a homogeneidade é uma característica desses direitos, quando considerados em conjunto.

Quanto ao conceito de homogeneidade, em si, também há de se acentuar que não basta simplesmente uma origem comum e remota para que ela fique configurada. A letra da lei pode dar a impressão que se exige que as diversas pretensões individuais decorram de uma mesma unidade factual ou temporal, interpretação esta que foi logo afastada pela doutrina $^{53}$. De fato, o legislador parece ter dito menos do que queria ao definir os interesses

\footnotetext{
${ }^{51}$ BARBOSA MOREIRA, José Carlos. Tutela jurisdicional dos interesses coletivos ou difusos. Revista de Processo, São Paulo, n. 39, p. 55, jul./set. 1985.

${ }^{52}$ Nesse sentido, ANTONIO GIDI ressalta que "os direitos individuais homogêneos se caracterizam por serem um feixe de direitos subjetivos individuais, marcado pela nota da divisibilidade, de que é titular uma comunidade de pessoas indeterminadas mas determináveis, cuja origem está em alegações comuns de fato ou de direito. (...) Percebe-se, nitidamente, ser a homogeneidade dos direitos individuais um conceito que bem poderia designar-se como relacional: um direito individual é homogêneo apenas em relação a um outro direito individual derivado da mesma origem (origem comum). Não há um direito individual homogêneo, mas direitos individuais homogeneamente considerados" (Coisa julgada e litispendência em ações coletivas. São Paulo: Saraiva, 1995. p. 30).

${ }^{53}$ A observação vem de um artigo publicado por KAZUO WATANABE em 1992, em que é dado o exemplo de atos ilícitos que se prolongam no tempo, mas de características uniformes: “Origem comum' não
} 
individuais homogêneos ${ }^{54}$, e não por acaso a doutrina aponta que, na análise do cabimento da ação civil coletiva, "a dificuldade ainda reside em discernir, com clareza, o que é e não é (e não pode ser) interesse ou direito individual homogêneo" ${ }^{, 55}$. Na realidade, o conceito processual de homogeneidade tem propósito instrumental; mais do que origem comum, o que lhe interessa é a uniformidade que torne possível e conveniente o tratamento em conjunto desses direitos individuais. No dizer de EURICO FERRARESI, pois, por homogêneo deve entender-se "o que apresenta unidade, adesão entre seus elementos, possuindo semelhança de estrutura e função"

Complementando a idéia de uniformidade na conceituação da homogeneidade processual, o artigo 95 do Código indica que as questões comuns a serem tratadas na fase coletiva devem ter uma extensão suficiente para, no mínimo, permitir a fixação de responsabilidade do réu. Um vínculo mais tênue do que isso, como por exemplo, a alegação de que pretensões completamente díspares teriam origem comum apenas por terem sido provocados danos por um mesmo fornecedor de serviços, não é suficiente para estabelecer a uniformidade ínsita ao conceito.

As cautelas na definição do conceito de homogeneidade são justificadas. A experiência norte-americana com a ação de classe indica que a má escolha das questões a serem tratadas em conjunto pode, em lugar de abreviar e racionalizar o procedimento, produzir exatamente o efeito contrário, atrasando o procedimento e exigindo a reabertura

significa, necessariamente, uma unidade factual e temporal. As vítimas de uma publicidade enganosa veiculada por vários órgãos de imprensa e em repetidos dias ou de um produto nocivo à saúde adquiridos por vários consumidores num largo espaço de tempo e em várias regiões têm, como causa de seus danos, fatos com homogeneidade tal que os tornam a 'origem comum' de todos eles" (WATANABE, Kazuo. Demandas coletivas e os problemas emergentes da práxis forense. Revista de Processo, São Paulo, n. 61, p. 15, jul./set. 1992).

${ }^{54}$ A insuficiência do conceito de "origem comum" para a definição da homogeneidade processual foi rapidamente percebida pela doutrina. ADA PELLEGRINI GRINOVER, a esse propósito, afirmou parecer "evidente, no entanto, que a origem comum - sobretudo se for remota - pode não ser suficiente para caracterizar a homogeneidade". Em seguida, comparando diferentes situações de danos com origem comum, veio a demonstrar que nem todas permitem um tratamento uniforme. Assim, "no consumo de um produto potencialmente nocivo, não haverá homogeneidade de direitos entre um titular que foi vitimado exclusivamente por esse consumo e outro, cujas condições pessoais de saúde lhe causariam um dano físico, independentemente da utilização do produto ou que fez deste uso inadequado. Não há homogeneidade entre situações de fato ou de direito sobre as quais as características pessoais de cada um atuam de modo completamente diferente" (Da class action for damages à ação de classe brasileira: os requisitos de admissibilidade, cit., p. 10).

${ }^{55}$ BUENO, Cássio Scarpinella. Tutela coletiva em juízo: uma reflexão sobre a alteração proposta para o art. 81, parágrafo único, inciso III, do CDC. Revista do Advogado, São Paulo, p. 19, dez. 2011.

${ }^{56}$ FERRARESI, Eurico. Ação popular, ação civil pública e mandado de segurança coletivo: instrumentos processuais coletivos. Rio de Janeiro: Forense, 2009. p. 283. 
da atividade instrutória sobre pontos da causa já examinados ${ }^{57}$. De outro lado, a prática brasileira com a ação civil coletiva apontou para a necessidade de que ela não seja processada como mero somatório de pretensões individuais, que acaba por inviabilizar a marcha do processo "pseudocoletivo" com a análise de uma ampla gama de questões que deveriam ser tratadas em processos específicos ${ }^{58}$. Na feliz síntese de LUIZ PAULO DA SILVA ARAÚJo FILHO, "uma ação coletiva para a defesa de direitos individuais homogêneos não significa a simples soma das ações individuais" ${ }^{, 59}$, exigindo-se cautelas redobradas do autor, ao propor a demanda, e do juiz, ao fixar os pontos que constituirão o objeto da controvérsia em audiência ou decisão preliminar (art. 331, §2º do Código de Processo Civil).

Nesse sentido, AdA PELlEGRINI GRINOVER propõe que o termo seja interpretado de acordo com os critérios que a jurisprudência norte-americana identificou para o cabimento das class actions for damages segundo a Rule 23, (b), (3), das Federal Rules of Civil Procedure de 1966: a predominância das questões coletivas e a superioridade da tutela coletiva sobre a individual $^{60}$. A predominância das questões comuns consiste na idéia de que as questões comuns entre os componentes da classe devem ser suficientes para permitir o tratamento do caso em um único processo. É requisito similar ao que se depreende do artigo 95 do Código de Defesa do Consumidor, segundo o qual o núcleo de homogeneidade deve ser ter extensão que permita a fixação de responsabilidade do réu. A superioridade da tutela coletiva está ligada à viabilidade do tratamento concentrado dos interesses individuais, podendo ser conduzida à condição de adequação do procedimento.

É importante que o autor da ação civil coletiva demonstre em sua inicial o preenchimento desses requisitos, como elemento acessório que se agrega à causa de pedir com a finalidade de demonstrar o interesse processual (sob o prisma da adequação) no

\footnotetext{
57، Trial bifurcation suffers from many of the difficulties of pretrial bifurcation, in addition to the new problem of Seventh Amendment compliance (...). If the bifurcation does not work, the ultimate conclusion of the trial might be extended rather than shortened, and witnesses who must now testify at two trails will be doubly inconvenienced" TIDMARSH, Jay; TRANSGRUD, Roger. Complex litigation: problems in advanced civil procedure, cit., p. 259.

${ }^{58} \mathrm{E}$ de particular interesse, a respeito, a leitura da monografia de LUIZ PAULO DA SILVA ARAÚJO FILHO, que a partir da análise de diversos casos práticos de demandas em que se pretendeu liquidar milhares de créditos individuais relacionados a reajustes de servidores públicos ou contas do Fundo de Garantia do Tempo de Serviço, conclui que "torna-se absolutamente inviável, por isso mesmo, o processamento de um feito, pseudocoletivo, que na verdade encerra pedidos singularizados em prol de centenas ou milhares de pessoas, visando à condenação específica do réu em benefício de cada uma delas, ou seja, mero somatório de pretensões individuais" (Ações coletivas: a tutela jurisdicional dos direitos individuais homogêneos, cit., p. 115).

${ }^{59}$ ARAÚJO FILHO, Luiz Paulo da Silva. Ações coletivas: a tutela jurisdicional dos direitos individuais homogêneos, cit., p. 114.

${ }^{60}$ GRINOVER, Ada Pellegrini. Da class action for damages à ação de classe brasileira: os requisitos de admissibilidade, cit., p. 5.
} 
procedimento especial que viabiliza a tutela dos interesses individuais sob a forma coletiva $^{61}$. A esse propósito, Gustavo MAURINO, EzEQUIEL NinO e MARTín Sigal frisam que para que seja possível uma ação coletiva, não basta que o fato da vida tenha projeção coletiva quanto aos sujeitos ou quanto ao objeto: é necessário que o fundamento do pedido possa também ser caracterizado como coletivo ${ }^{62}$. O conceito processual de homogeneidade, em tal sentido, nos parece ter um caráter precipuamente instrumental; muito mais do que critérios objetivos preestabelecidos por construções doutrinárias, a interpretação da lei deve tomar por ponto de partida uma abordagem pragmática. Direitos individuais homogêneos são aqueles cujas afinidades permitem e tornam conveniente uma análise concentrada, em um único processo, dos aspectos comuns a toda uma "classe" de titulares.

Dessa forma, os interesses individuais homogêneos podem, eventualmente, ser tutelados por meio de outros procedimentos que não a ação coletiva. Esta se destina, tipicamente, à proteção dos interesses individuais homogêneos em que haja uma margem significativa de questões individuais a ser investigada em cada caso concreto, tornando necessária a divisão da atividade cognitiva em processos distintos. Caso os interesses individuais sejam absolutamente uniformes, e não necessitem de uma fase de individualização - como se dá na tutela declaratória que tenha por objeto a nulidade de determinada cláusula lesiva ao consumidor em contratos individuais padronizados - a sua proteção pode se dar através de outros procedimentos de tutela coletiva, como a ação civil pública. A ação civil coletiva é procedimento específico para os interesses individuais homogêneos que necessitem de uma fase de individualização da cognição, razão pela qual ela é preordenada à tutela de direitos de crédito fundados em responsabilidade civil, repetição do indébito, ou vícios redibitórios por defeitos no produto ou na prestação do

\footnotetext{
${ }^{61}$ Nesse sentido, JOSÉ MARCELO DE MENEZES VIGLIAR (A causa de pedir e os interesses individuais homogêneos. In: TUCCI, José Rogério Cruz e; BEDAQUE, José Roberto dos Santos (Coords.). Causa de pedir e pedido no processo civil: questões polêmicas. São Paulo: Ed. Revista dos Tribunais, 2002. p. 215). Em sentido contrário, ADA PELLEGRINI GRINOVER coloca a questão em termos de possibilidade jurídica do pedido (Da class action for damages à ação de classe brasileira: os requisitos de admissibilidade, cit., p. 10), talvez a mais controversa das condições da ação. Como a ausência desses requisitos afasta apenas a possibilidade instrumental de fragmentação da cognição judicial em processos distintos voltados a questões comuns e particulares, que é uma questão procedimental, mas não exclui a possibilidade abstrata da procedência do mérito dos pedidos indenizatórios, parece-nos que a primeira posição é mais acertada.

${ }^{62 “} \mathrm{La}$ mera pluralidad de sujetos, o el mero impacto colectivo del remedio solicitado, del objeto de la pretensión, no alcanzan para que el caso sea colectivo: también la causa debe tener una dimensión colectiva. (...) la dimensión jurídica de incidencia colectiva genera una conexión jurídica entre la situación de diversos sujetos, que permite un encuadre jurídico único e común de ciertos hechos a los fines de una pretensión jurídica" (MAURINO, Gustavo; NINO, Ezequiel; SIGAL, Martín. Las acciones colectivas: análisis conceptual, constitucional, procesal, jurisprudencial y comparado. Buenos Aires: Lexis Nexis Argentina, 2005. p. 204-205).
} 
serviço. De início, parte da doutrina restringia o cabimento da ação civil coletiva apenas a direitos fundados nas disposições especiais do Código de Defesa do Consumidor ${ }^{63}$, atualmente há consenso de que as suas disposições se aplicam a todas as ações coletivas para a defesa de direitos individuais que não contam com regulamentação específica.

\subsubsection{Direitos homogêneos excluídos da tutela coletiva}

Posteriormente à edição do Código de Defesa do Consumidor, em 1997 e 1999, o Poder Executivo brasileiro editou duas Medidas Provisórias com a finalidade de restringir a tutela coletiva no país, especialmente - mas não apenas - no que diz respeito a seus próprios interesses $^{64}$, que vieram a se sedimentar na forma da Lei ${ }^{\circ}$ 9.494/97 e da MP 2.180/01 (vigente na forma da Emenda Constitucional $\mathrm{n}^{\circ}$ 32/01). Por meio delas, foi inserido o parágrafo único ao artigo $1^{\circ}$ da Lei no 7.347/85, que dispõe que "não será cabível ação civil pública para veicular pretensões que envolvam tributos, contribuições previdenciárias, o Fundo de Garantia do Tempo de Serviço - FGTS ou outros fundos de natureza institucional cujos beneficiários podem ser individualmente determinados".

Embora a alteração tenha sido introduzida na lei da ação civil pública, instrumento voltado à tutela dos direitos essencialmente coletivos, não há dúvidas que na realidade a regra de exclusão se dirige às ações civis coletivas, na medida em que se faz menção à possibilidade de determinação dos indivíduos beneficiários das pretensões. Ora, esse é justamente o elemento que distingue a categoria dos direitos individuais homogêneos (art. 81, inciso III, da Lei $n^{\circ}$ 8.078/90). Em suma, portanto, passou a ser proibido no direito brasileiro o ajuizamento de ações coletivas que ameacem a arrecadação de receitas tributárias ou extrafiscais do Estado, ou que dele vindiquem benefícios assistenciais ou previdenciários.

\footnotetext{
${ }^{63}$ Assim JOÃO BATISTA DE ALMEIDA, que mesmo dez anos após edição do Código, adotava esse viés restritivo: "a ação civil coletiva, criada em 1990, pelo Código de Defesa do Consumidor, destina-se à defesa coletiva unicamente do consumidor, vítimas ou sucessores (e não de outros bens tutelados), e é adequada para a defesa dos interesses ou direitos individuais homogêneos de origem comum, divisíveis por natureza, apresentando, desse modo, campo de utilização bem mais restrito do que o da ação civil pública" (A ação civil coletiva para a defesa de interesses ou direitos individuais homogêneos. Revista de Direito do Consumidor, São Paulo, v. 9, n. 34, p.89, abr./jun. 2000).

${ }^{64}$ As exceções à lei processual criadas em benefício exclusivo da Fazenda Pública, reflexo de uma desconfiança institucional do Poder Executivo frente ao Judiciário na visão do autor, são objeto da crítica de JOSÉ IGNÁCIO BOTELHO DE MESQUITA, no artigo A crise do judiciário e o processo. In: Teses, estudos e pareceres de processo civil: direito de ação - partes e terceiros - processo e política. São Paulo: Ed. Revista dos Tribunais, 2005. v. 1, p. 255-262).
} 
Uma série de fatores pode ser apontada como causa desse desdobramento. A hipótese mais provável é o processo coletivo possa ter sido vítima de sua própria eficiência, e que se tenha vislumbrado o risco de desequilíbrio nas contas de governos que, há muito, estavam habituados às vantagens da posição de litigante habitual contra seus próprios cidadãos, bem como ao financiamento de suas dívidas judiciais pelos largos prazos que a sobrecarga dos tribunais impõe à conclusão dos processos individuais contra o poder público. A situação é complexa ${ }^{65}$, pois ao mesmo tempo em que é moralmente condenável tal postura de governo ${ }^{66}$, de outro lado a eventual insolvabilidade do Estado geraria prejuízos certos e significativos para a toda sociedade. Tratava-se de escolha eminentemente política, portanto, em que nenhuma das escolhas que se apresentavam diante do legislador - que deu respaldo à medida provisória editada pela presidência da República - poderia ser considerada isenta de críticas.

\subsubsection{Limitação territorial dos efeitos da sentença e determinação da juntada da relação de associados ou filiados}

Além da exclusão de determinadas matérias, as medidas provisórias restritivas à tutela de direitos individuais homogêneos também visaram a delimitar a sua eficácia segundo o âmbito da competência territorial do juízo da causa. Utilizando uma redação tecnicamente mais adequada do que o criticado artigo 16 da Lei $\mathrm{n}^{\mathrm{o}} 7.347 / 85$, o artigo $2^{\circ}$-A

\footnotetext{
${ }^{65}$ A complexidade da situação, que não pode ser abstraída do acúmulo de décadas de más práticas administrativas e de governo, foi bem apreendida por HUGO NIGRO MAZZILLI: “(...) é como se o governante dissesse assim: como a Constituição e as leis instituíram um sistema para defesa coletiva de direitos, e como esse sistema pode ser usado contra o governo, então impeço o funcionamento do sistema para não ser acionado em ações coletivas, onde posso perder tudo de uma só vez. Sim, o fundamento é esse, pois, se, em vez da ação coletiva tiver de ser usada a ação individual, cada lesado terá de contratar individualmente um advogado para lutar em juízo. Em caso de danos dispersos na coletividade, isso só será bom para o causador do dano, nunca para os lesados, já que, na prática, a grande maioria dos lesados não buscará acesso individual à jurisdição, diante das enormes dificuldades práticas supervenientes (honorários de advogados, despesas processuais, demora, pequeno valor do dano individual, decisões contraditórias etc.). E é com isso que contam os governantes, quando cobram 'empréstimos compulsórios' jamais devolvidos, criam contribuições 'provisórias' que se tornam definitivas; cobram impostos confiscatórios sobre salários; retêm devoluções de impostos cobrados a mais, negam devolução da correção monetária de que se apropriou o Estado nas contas do FGTS" (MAZZILI, Hugo de Nigro. A defesa dos interesses difusos em juízo. 19. ed. São Paulo: Saraiva, 2006. p. 136).

${ }^{66}$ As críticas da doutrina, a propósito, têm sido veementes. Nesse sentido, ADA PELLEGRINI GRINOVER fala em "intervenções autoritárias do governo" (A ação civil pública refém do autoritarismo, cit., p. 28-36), enquanto LUIZ PAULO DA SILVA ARAÙJO FILHO fala em "ataque clandestino" em meio a uma "tática de guerrilha contra as ações coletivas" (Ações coletivas: a tutela jurisdicional dos direitos individuais homogêneos. Rio de Janeiro: Forense, 2000. p. 167).
} 
da Lei $n^{\circ} 9.494 / 97^{67}$, incluído pela Medida Provisória $n^{\circ} 2.180-35 / 01$, veio a determinar que "a sentença civil prolatada em ação de caráter coletivo proposta por entidade associativa, na defesa dos interesses e direitos dos seus associados, abrangerá apenas os substituídos que tenham, na data da propositura da ação, domicílio no âmbito da competência territorial do órgão prolator". Essa regra teria o potencial de limitar o objeto da ação civil coletiva, estabelecendo uma restrição à habilitação dos indivíduos que compõem a classe segundo o seu domicílio na data da propositura da demanda.

Mas, no entanto, apesar de a jurisprudência inicialmente ter limitado os efeitos da sentença à comarca ou seção judiciária do juiz prolator da sentença, passou a prevalecer o ponto de vista de que a alteração não representou grande mudança em relação ao que já era determinado pelo artigo 93 da Lei $n^{\circ}$ 8.078/90, que distribuíra desde sempre a competência territorial para processar a ação civil coletiva segundo o impacto do dano a ser nela discutido. De fato, há que se atentar para que a competência para o processamento da ação civil coletiva se orienta por critérios territoriais especiais em relação aos do Código de Processo Civil, pois para ela será competente o foro do lugar onde ocorreu ou deva ocorrer o dano, quando este for de âmbito local (art. 93, inciso I); ou o foro da Capital do Estado ou do Distrito Federal, para os danos de âmbito nacional ou regional (art. 93, inciso II). Da conjugação das duas regras, portanto, resulta que nos danos locais a sentença abrangerá os substituídos que tenham domicílio na comarca a que se limitou o dano; nos danos

\footnotetext{
${ }^{67}$ A redação atribuída ao artigo 16 da Lei da Ação Civil Pública pela mesma Lei no 9.494/97 ("a sentença civil fará coisa julgada erga omnes, nos limites da competência territorial do órgão prolator, exceto se o pedido for julgado improcedente por insuficiência de provas, hipótese em que qualquer legitimado poderá intentar outra ação com idêntico fundamento, valendo-se de nova prova") chega a ser desconcertante ao limitar a coisa julgada aos limites de competência territorial do órgão prolator. A regra não chega a causar inconvenientes pelo fato de não interferir na eficácia da sentença e na tutela por ela prestada (alterações que a sentença produz na realidade jurídica), que é fenômeno distinto da coisa julgada (imutabilidade e indiscutibilidade da sentença). Isto foi muito bem observado pelo acórdão do Superior Tribunal de Justiça no REsp 399.357/SP, segundo o qual "distinguem-se os conceitos de eficácia e de coisa julgada. A coisa julgada é meramente a imutabilidade dos efeitos da sentença. O art. 16 da LAP, ao impor limitação territorial à coisa julgada, não alcança os efeitos que propriamente emanam da sentença. Os efeitos da sentença produzem-se "erga omnes", para além dos limites da competência territorial do órgão julgador. Recurso Especial improvido" (Terceira Turma, rel. Min. NANCY ANDRIGHI, j. 17.03.2009, p. DJ e 20.04.2009). Quanto à competência territorial dos juízes para julgar, é certo que a sua extensão compreende todo o território nacional; embora ela seja distribuída a cada um dos juízes segundo critérios que vinculados à divisão geográfica do território. A limitação ao território nacional seria inócua e diria o óbvio, porque tais são os limites de competência da autoridade judiciária brasileira; de outro lado, a limitação da coisa julgada à comarca ou ao Estado que corresponde à parcela de competência entregue ao juiz que julgou a causa gera o inconveniente de, eventualmente, permitir a rediscussão de uma decisão eficaz e já coberta pela coisa julgada na comarca vizinha, podendo dar ensejo inclusive à contrariedade prática de julgados sobre o mesmo objeto. Essa possibilidade, contudo, acabou por ser contornada pela posterior introdução do parágrafo único ao artigo $2^{\circ}$, que tornou o primeiro juízo prevento para conhecer de eventual segunda demanda com o mesmo objeto. $\mathrm{O}$ dispositivo limitador do artigo 16 ficou assim esvaziado de qualquer eficácia, mas ainda persiste no ordenamento como símbolo eloqüente de sistematização caótica e irracional, que era propiciada pela atualmente vedada alteração da legislação processual pelo instrumento da medida provisória.
} 
regionais, ela abrangerá os que tenham domicílio no Estado (ou Estados) em que este ficou confinado; e nos danos de âmbito nacional, ela abrangerá os substituídos que tenham domicílio no país ${ }^{68}$. O único prejuízo que a regra pode possivelmente gerar é a exclusão das vítimas do dano que tenham sido atingidas em trânsito, sem que detivessem domicílio no local ou na região, resultado este que parece bastante arbitrário e de difícil justificação. No entanto, há de se reconhecer que é uma eventualidade bem improvável de se verificar na realidade prática.

Mais significativa, porém, embora limitada às ações movidas por entidades associativas contra a Fazenda Pública ${ }^{69}$, é a regra do parágrafo único ao mesmo artigo $2^{\circ}$ A, segundo a qual "a petição inicial deverá obrigatoriamente estar instruída com a ata da assembléia da entidade associativa que a autorizou, acompanhada da relação nominal dos seus associados e indicação dos respectivos endereços". Com base nesse dispositivo, é estabelecido um ônus processual, em razão do qual as associações devem indicar desde logo os potenciais beneficiários da sentença genérica coletiva, sob a pena de indeferimento da inicial. Também essa norma tem impacto mais reduzido do que poderia parecer à primeira vista, porque a partir do momento em que foram subtraídos da tutela coletiva os direitos de natureza tributária e previdenciária ( $c f$. item 2.3.1.1), o campo de cabimento da tutela coletiva de direitos contra a Fazenda Pública ficou reduzido basicamente às ações movidas por servidores públicos sujeitos à legislação estatutária ou trabalhista, que integram um contencioso particularizado e tradicionalmente organizado pela ação das associações e sindicatos de trabalhadores. Ao que parece, portanto, a regra foi motivada por uma dificuldade conjuntural da Fazenda Pública em administrar um grande acervo de ações judiciais de modo a informar nos autos das ações individuais concorrentes a propositura da ação coletiva, para evitar sua sujeição a julgamentos conflitantes (art. 104 da Lei $n^{\circ}$ 8.078/90), e sua intenção foi a de deslocar essa responsabilidade para as

\footnotetext{
${ }^{68}$ Essa interpretação veio a ser afirmada pelo Superior Tribunal de Justiça no julgamento dos recursos especiais repetitivos $n^{\circ}$ 1.243.887 (Corte Especial, rel. Min. Luis Felipe Salomão, j. 19.10.2011, p. DJe 09.12.2011) e $\mathrm{n}^{\mathrm{o}}$ 1.247.150 (Corte Especial, rel. Min. Luis Felipe Salomão, j. 19.10.2011, p. DJe 09.12.2011), em que ficou fixado que "a liquidação e a execução individual de sentença genérica proferida em ação civil coletiva pode ser ajuizada no foro do domicílio do beneficiário, porquanto os efeitos e a eficácia da sentença não estão circunscritos a lindes geográficos, mas aos limites objetivos e subjetivos do que foi decidido, levando-se em conta, para tanto, sempre a extensão do dano e a qualidade dos interesses metaindividuais postos em juízo (arts. 468, 472 e 474, CPC e 93 e 103, CDC)".

${ }^{69}$ Eliminando dúvidas que pudesse haver a respeito, o Superior Tribunal de Justiça decidiu no REsp 879.773/RS que "a autorização de associados só é necessária nas ações coletivas propostas contra a União, os Estados, o Distrito Federal, os Municípios e suas autarquias e fundações (Art. $2^{\circ}$-A, parágrafo único, da Lei 9.494/97)" (Terceira Turma, rel. Min. HUMBERTO GOMES DE BARROS, j. 24.03.2008, p DJe 13.05.2008).
} 
entidades representativas dos trabalhadores públicos. Como essas entidades dispõem de um grau de organização elevado (ao contrário do que se passa em relação a outros direitos típicos da sociedade de massas), a disposição não chega a impedir o acesso dos indivíduos à tutela coletiva ${ }^{70}$. Ainda assim ela gera dificuldades interpretativas no tocante à situação de substituídos que não fossem filiados à entidade associativa no momento da propositura da demanda ${ }^{71}$, ou de haver concurso entre ações coletivas parcialmente concorrentes, entre outras. Trata-se de solução imperfeita criada para lidar com uma contingência administrativa específica do momento de criação da norma, e que merece ser reavaliada no futuro.

\subsubsection{As ações complementares}

Caso o juiz se convença pela responsabilidade do réu, contudo, será proferida sentença genérica que reconheça - de modo ainda indeterminado, sobretudo no que diz respeito aos titulares dos direitos a que se dirige a tutela jurídica ${ }^{72}$ - a obrigação de indenizar (artigo 95 da Lei $n^{\circ}$ 8.078/90). Essa sentença não entrega aos indivíduos substituídos em juízo a tutela adequada para sanar a crise de cooperação gerada pela lesão de massa, e tampouco é suficiente para proporcionar à sociedade a proteção, de projeção coletiva, representada pelo desestímulo à conduta lesiva.

Para que essa dupla finalidade, que está à base do processo coletivo, possa ser atingida, essa sentença genérica exige complementação em outros processos em que se examinará a margem de questões heterogêneas que não pode ser incluída na fase coletiva. A complementação da tutela jurisdicional coletiva pode prosseguir por duas formas: por diversas ações individuais a serem promovidas pelos membros da classe, segundo os padrões do processo comum em que será necessária a prova do nexo causal e do dano

\footnotetext{
${ }^{70}$ Tendo em conta essas especificidades, discordamos da posição de PEDRO LENZA, segundo a qual esse tratamento diferenciado entre a Fazenda Pública e outros réus em ações civis coletivas é inconstitucional por violação à regra da isonomia (Teoria geral da ação civil pública. 3. ed. São Paulo: Ed. Revista dos Tribunais, 2008. p. 277).

${ }^{71}$ A jurisprudência do Superior Tribunal de Justiça tem se encaminhado para o entendimento de que a lista de associados não restringe o universo de beneficiários da sentença coletiva, na medida em que "o servidor possui legitimidade para propor execução individual oriunda de ações coletivas, ainda que não tenha autorizado a associação ou o sindicato de sua categoria para lhe representar na ação de conhecimento" (Agr. Rg. em Agr. de Instrumento 1.186.993, Sexta Turma, rel. Min. OG FERNANDES, j. 17.08.2010, p. DJe 06.09.2010).

${ }^{72}$ Trata-se, sobretudo, de sentença "subjetivamente ilíquida", na expressão de LUIZ PAULO DA SILVA ARAÚJO FILHO (Ações coletivas: a tutela jurisdicional dos direitos individuais homogêneos, cit., p. 123).
} 
pessoalmente sofrido; ou por meio de um único processo, em que a globalidade das reparações será tratada de maneira aproximada ou estatística, revertendo o produto da execução a alguma aplicação de interesse coletivo. Dada a finalidade comum entre as duas, podemos chamá-las de ações complementares.

Na América do Norte, há uma linha de pensamento que mesmo os direitos tipicamente individuais de conteúdo mais elevado devem receber tratamento coletivo, com base em modelos estatísticos, na medida em que a finalidade da class action seria primariamente a de promover a mudança institucional por meio da dissuasão (“deterrence") e apenas secundariamente compensar de maneira justa os indivíduos ${ }^{73}$. Verifica-se, no entanto, que a legislação brasileira trilhou caminho inverso e adotou como prioridade a recomposição do patrimônio individual de cada membro da classe, tanto ao conferir um tratamento residual à execução coletiva, que é condicionada a não se habilitarem indivíduos em número compatível com a gravidade do dano causado, como ao dispor que, ao concorrerem execuções individuais com execução em prol do fundo de direitos difusos, aquelas têm a preferência no levantamento do saldo da execução (artigos 99 e 100 da Lei $\left.n^{\circ} 8.078 / 90\right)$.

Essa opção do legislador, em nossa opinião, foi a mais adequada para a realidade brasileira. Em nosso país, ao contrário do que ocorre nos Estados Unidos, o problema de acesso à Justiça relacionado aos "novos direitos" não consiste primordialmente nas barreiras econômicas à tutela dos direitos individuais, tendo em vista que as taxas judiciárias não são excessivamente altas, há um sistema bastante generoso de gratuidade processual, há procedimentos simplificados para causas de pequeno valor, e os serviços técnico-jurídicos de advocacia também não são nem indispensáveis (em ações de natureza trabalhista e em juizados especiais é reconhecido o direito de postulação direta) e nem inacessíveis $^{74}$. O grande problema que se verifica na realidade forense brasileira está na

\footnotetext{
73،'There is a residual debate about whether the 'private law model' advantages of fragmenting the mass hearing of non-common issues outweight the 'public law model' advantages of considering all claims together to maximise gross recovery and minimise global transaction costs. Many 'public law model scholars', such as Rosenberg, go so far as to suggest that all issues, even inherently individualistic questions such as causation and voluntary assumption of risk, should be considered on a global, statistical basis, and a single compensation figure arrived at. This amount would then be distributed among plaintiffs according to appropriate social priorities" (JONES, Craig. Theory of class actions: optimal aggregation in mass tort litigation, cit., p. 86). Na realidade, o processo coletivo tem interesses conflitantes, e o que se mostra tratamento adequado para direitos de conteúdo quase desprezível (small claim class actions), que de outra maneira não seriam levados a juízo, não se coaduna com aquele que se ajusta a ações que de outro modo seriam levadas aos tribunais em processos individuais (mass torts class action).

${ }^{74} \mathrm{Na}$ realidade, como anota RUY ZOCH RODRIGUES, no caso brasileiro encontra-se estruturado todo um segmento de advocacia especializado com o tratamento atomizado de demandas de massa. "Muitos
} 
sobrecarga que a intensa litigiosidade gerada pelos litígios de massa acarreta sobre os tribunais. Mais do que um problema de litigiosidade contida, nosso país deve lidar com o represamento de processos que efetivamente são canalizados às instituições responsáveis pela administração a Justiça. Isso se verifica pela constatação de que mesmo demandas de pequeno conteúdo econômico, como aquelas relacionadas a tarifas de telefone ou acidentes menores de consumo, chegam, em grandes volumes, aos tribunais ${ }^{75}$.

Nesse contexto, o legislador não poderia ter deixado de priorizar a efetiva destinação da reparação a cada titular de direito lesionado, sob pena de privar de qualquer proteção jurisdicional direitos individuais a que já são asseguradas formas, ainda que deficientes, de proteção individual. Se o fizesse, acabaria por incorrer em inconstitucionalidade, nos termos do artigo $5^{\circ}$, inciso XXXV, do texto de 1988.

\subsubsection{Ações individuais de cumprimento}

Se ao final da ação coletiva for decidido que a porção homogênea das pretensões individuais é fundada, e for assim fixada a responsabilidade genérica do réu (artigo 95 da Lei ${ }^{\circ}$ 8.078/90), haverá a necessidade de complementação da atividade jurisdicional com novos processos em que se examine a presença dos elementos restantes para que se possa autorizar a entrega da tutela buscada em juízo. Nessa fase complementar, destinada à resolução das questões heterogêneas próprias a cada pessoa atingida pelo evento danoso, por regra o processo coletivo recupera o seu caráter individual, desdobrando-se em diversas demandas de conhecimento a serem promovidas por cada um dos interessados ${ }^{76}$.

escritórios se organizam como empresas para tratar justamente de temas massificados, construindo verdadeiras linhas de montagem que seguem a lógica do ganho em escala. O mesmo produto é replicado com alto grau de automatização e, assim, o volume dilui os custos e maximiza os lucros." (Ações repetitivas: casos de antecipação de tutela sem o requisito de urgência. São Paulo: Ed. Revista dos Tribunais, 2010. p. 95).

${ }^{75}$ WATANABE, Kazuo. Relação entre demanda coletiva e demandas individuais. Revista de Processo, São Paulo, n. 139, set. 2006.

${ }^{76}$ A doutrina que se debruçou sobre a ação coletiva para tutela de direitos individuais homogêneos converge para a conclusão de que, na fase de habilitação e liqüidação, o processo perde o seu caráter coletivo, e assume as feições do processo individual. Assim, "as peculiaridades de cada caso são aferidas apenas na fase de liqüidação da sentença coletiva, que é verdadeira ação individual em que cada titular do direito individual deverá provar não somente o montante do seu crédito, como que efetivamente faz parte da comunidade de vítimas do evento submetido e julgado na referida sentença" (GIDI, Antonio. Coisa julgada e litispendência em ações coletivas, cit., p. 32). 
"Abre-se em leque" o procedimento especial, para utilizarmos uma expressão de CÂNDIDO DINAMARCO $^{77}$, em tantos processos quanto sejam os indivíduos beneficiados pela sentença.

Sobre isso, o artigo 97 do Código dispõe, singelamente, que em caso de ser proferida sentença genérica de procedência, "a liqüidação e a execução de sentença poderão ser promovidas pela vítima e seus sucessores, assim como pelos legitimados de que trata o art. 82". Tratando-se de ações individuais, é necessário que cada autor outorgue poderes a advogado habilitado para que as ações sejam movidas em seu nome, ou que ele confira poderes específicos de representação aos legitimados coletivos para que eles postulem em juízo o reconhecimento dos elementos particulares de cada pretensão individual, executem e recebam os valores das respectivas condenações. Em linhas gerais, trata-se de processo em que, a depender da margem de questões heterogêneas, poderá haver um largo espaço de cognição. Não é por outra razão que o Superior Tribunal de Justiça veio a editar a súmula 345, reconhecendo à ação individual de habilitação o regime de honorários advocatícios próprio aos processos de conhecimento ${ }^{78}$. Esse elevado grau de autonomia do processo individual de cumprimento da sentença coletiva também faz com que a competência para seu processamento se determine pelos critérios das ações $\operatorname{ordinárias~}^{79}$, de modo que, no mesmo foro, as ações complementares individuais serão livremente distribuídas; cada substituído terá liberdade para promover a ação individual em outro foro que não aquele que processou a ação civil coletiva.

No processo individual de cumprimento da sentença coletiva, em primeiro lugar caberá ao autor comprovar a pertinência de sua pretensão individual à causa de pedir

${ }^{77}$ DINAMARCO, Cândido Rangel. Instituições de direito processual civil. 6. ed. São Paulo: Malheiros Ed., 2009. v. 4, p. 736.

${ }^{78} \mathrm{O}$ verbete $\mathrm{n}^{\mathrm{o}} 345$ da Súmula do Superior Tribunal de Justiça, publicado no diário oficial de 28.11.2007, tem a seguinte redação "São devidos honorários advocatícios pela Fazenda Pública nas execuções individuais de sentença proferida em ações coletivas, ainda que não embargadas".

${ }^{79} \mathrm{O}$ parágrafo único do artigo 97 do Código do Consumidor trazia essa previsão de forma explícita, segundo a fórmula de que "liqüidação de sentença, que será por artigos, poderá ser promovida no foro do domicílio do liquidante, cabendo-lhe provar, tão-só, o nexo de causalidade, o dano e seu montante." Essa regra foi vetada pela Presidência da República sob o fundamento de que "dispositivo dissocia, de forma arbitrária, o foro dos processos de conhecimento e de execução, rompendo o princípio da vinculação quanto à competência entre esses processos, adotado pelo Código de Processo Civil (Art. 575) e defendido pela melhor doutrina. Ao despojar uma das partes da certeza quanto ao foro de execução, tal preceito lesa o princípio de ampla defesa assegurado pela Constituição" (Mensagem nº 644, de 11.11.90). O que a mensagem de veto não percebeu é que as ações de cumprimento da sentença coletiva são autênticas ações individuais, cuja competência é determinada pelo domicílio do autor na maioria dos casos de lesão de massa, de modo que a regra vetada não mais explicitava uma decorrência necessária daquilo que é da essência dessa ação individual. $O$ vazio deixado pelo veto, nada obstante as razões enunciadas pelo Presidente da República, não poderia alterar as regras ordinárias de competência presentes no Código de Processo Civil. Essa interpretação, muito a propósito, foi recentemente afirmada pelo Superior Tribunal de Justiça ao julgar os recursos especiais repetitivos $\mathrm{n}^{\circ}$ 1.243.887 e $\mathrm{n}^{\circ}$ 1.247.150 (Corte Especial, rel. Min. Luis Felipe Salomão, j. 19.10.2011, p. DJe 09.12.2011). 
comum à classe, de maneira a se habilitar como beneficiário da coisa julgada formada na sentença coletiva. Deve se observar que, para que a habilitação seja possível, não basta ao autor alegar que sofreu danos em razão da conduta do réu; ele deve demonstrar que a sua situação individual se amolda fielmente àquela "situação-tipo" homogênea que foi considerada de maneira uniforme na ação civil coletiva. Julgando-se que o autor está habilitado à liqüidação e execução, a sentença genérica terá sido integrada em seu mérito com a decisão sobre o cui debeatur, isto é, com a pertinência subjetiva da parcela da pretensão resolvida de maneira genérica ${ }^{80}$.

O segundo grupo de questões que compõem a ação individual consiste, propriamente, na liqüidação do dano sofrido pelo membro da classe. O processo, então, visará "a completar a atividade cognitiva, que foi apenas parcial" 81 , aferindo a certeza sobre a existência e extensão dos danos individuais. Como para isso, tipicamente, haverá necessidade de alegar e provar fatos novos, no mais das vezes o procedimento a ser observado é o da liqüidação por artigos (artigo 475-E, Código de Processo Civil).

Como matéria de defesa na ação complementar de habilitação e liqüidação, será cabível a introdução de exceções pessoais contra o indivíduo, como a prescrição ${ }^{82}$ ou a compensação da condenação com créditos frente ao autor, exceções estas que - a vista de seu caráter particular - sequer poderiam ter sido deduzidas na fase coletiva. LUIz PAULO DA SILVA ARAúJo FILHO admite até mesmo a alegação de culpa concorrente ${ }^{83}$, embora a

\footnotetext{
${ }^{80}$ PATRÍCIA MIRANDA PIZZOL sustenta que a prova do nexo causal se insere na demonstração de legitimidade ativa para executar a sentença (Liqüidação nas ações coletivas. São Paulo: Lejus, 1988. p. 195). No entanto, como a decisão não é feita a partir da mera asserção do autor, exigindo o exame da pretensão de habilitação à luz dos fatos alegados e provas produzidas, parece ter razão no particular LUIZ RODRIGUES WAMBIER, que afirma se tratar de questão de mérito (Liqüidação da sentença civil: individual e coletiva. 4. ed. reformulada, atualizada e ampliada da obra Sentença civil: liqüidação e cumprimento. São Paulo: Ed. Revista dos Tribunais, 2009. p. 309-310).

${ }^{81}$ ZAVASCKI, Teori. Processo coletivo: tutela de direitos coletivos e tutela coletiva de direitos, cit., p. 181.

${ }^{82} \mathrm{~A}$ respeito da possibilidade de análise da prescrição do crédito individual, mesmo sendo ela antecedente à sentença genérica, é interessante o julgado do recurso especial 1.100.970 pelo Superior Tribunal de Justiça: "1. A prescrição pode ser invocada em sede de embargos à execução de título judicial, quando se tratar de execução individual de sentença proferida em ação coletiva. 2. A execução de sentença genérica de procedência, proferida em sede de ação coletiva lato sensu - ação civil pública ou ação coletiva ordinária -, demanda uma cognição exauriente e contraditório amplo sobre a existência do direito reconhecido na ação coletiva. (...). 3. O art. 741, VI, do CPC, sobre interditar a suscitação de questão anterior à sentença, nos embargos à execução, não se aplica a execução individual in utilibus, porquanto é nessa oportunidade que se pode suscitar a prescrição contra a pretensão individual, mercê de a referida defesa poder ser alegada em qualquer tempo e grau de jurisdição. (...)."(Primeira Turma, rel. Min. LUIZ FUX, j. 01.12.2009, p. DJe 18.12.2009). No mesmo sentido, no recurso especial, 1.051.305, decidiu-se que "em ações coletivas a condenação deve ser genérica, de modo que a verificação quanto à prescrição do crédito de cada um dos particulares substituídos pela entidade legitimada à propositura da ação deve ser verificada em liqüidação de sentença" (Terceira Turma, rel. Min. NANCY ANDRIGHI, j. 23.03.2010, p. DJ 28.04.2010).

${ }^{83}$ ARAÚJO FILHO, Luiz Paulo da Silva. Ações coletivas: a tutela jurisdicional dos direitos individuais homogêneos, cit., p. 195.
} 
possibilidade dessa discussão tenha por pressuposto uma sentença em tamanho grau abstrata, que somente poderia ter sido baseada em uma ação coletiva que não atendia o requisito da predominância dos aspectos comuns (e que, portanto, não deveria ter sido admitida). Caso seja proferida sentença genérica com tamanho grau de vagueza, contudo, mesmo defesas relativas à caracterização da obrigação terão de ser admitidas no processo individual, com o único inconveniente de que o processo coletivo não terá contribuído para propiciar economia significativa de tempo e recursos.

\subsubsection{Ação de liquiiidação e execução coletiva}

O artigo 100 da Lei $n^{\circ}$ 8.078/90 prevê que, no prazo de um ano do trânsito em julgado da sentença genérica coletiva, e na hipótese de que não sejam ajuizadas ações individuais de liqüidação em número compatível com a gravidade do dano, os mesmos legitimados para propor a ação principal poderão "promover a liqüidação e execução da indenização devida”. Nesse caso, os valores serão globalmente liquidados, e a execução reverterá em prol do fundo de recomposição dos bens lesados, de que fala o artigo 13 da Lei $n^{\circ} 7.347 / 85$ (Lei da ação civil pública), ou diretamente à União em caso de danos a investidores. Há assim um prazo decadencial ${ }^{84}$ de um ano em matéria de consumo, e dois anos em matéria de mercado de capitais (art. $2^{\circ}$, Lei n. 7.913/89), para que as vítimas e sucessores promovam suas ações individuais de habilitação, porque a partir daí o montante global da condenação genérica passará a ser devido ao Estado.

Como dissemos mais cedo, diante complexidade das lesões de massa, o legislador se vê confrontado com duas alternativas para estreitar o número de questões do processo e viabilizar a decisão da causa: ou elas são divididas em processos distintos e sucessivos, que visam à efetiva recomposição de cada direito lesionado; ou elas são tratadas por aproximação, mediante técnicas de estatística e de indenização pelo equivalente, em um procedimento unificado aberto a maiores margens de erro. O objetivo da primeira técnica, ao responsabilizar o réu, está em dispensar a tutela jurídica a cada titular do direito ao ressarcimento ("mass torts"); enquanto o da segunda está no efeito de desestímulo que a sanção produz sobre a sua conduta, quando a pequena expressão de cada direito individual

\footnotetext{
${ }^{84}$ DIDIER JR., Fredie; ZANETI JR., Hermes. Curso de direito processual civil: processo coletivo. 6 . ed. Salvador: Juspodium Ed., 2011. v. 4, p. 284.
} 
não for suficiente para despertar o interesse de seus titulares ("small claims"). O processo coletivo brasileiro dá tratamento unificado aos dois tipos de ação coletiva. A opção prioritária feita pelo legislador consiste em que cada interessado promova uma ação específica com a finalidade de apurar os danos individualmente sofridos, e promova a execução em seu próprio favor. A ação de liqüidação e execução coletiva tem, como se constata, uma aplicação residual. Como a regra é mais afeta ao direito material do que ao processual, na medida em que por meio dela ela, a rigor, se opera a conversão substancial de diversas obrigações em face de uma massa indivíduos em uma única obrigação devida ao Estado, a doutrina sustenta que a execução coletiva é instituto exclusivo das ações coletivas fundadas em relações de consumo ${ }^{85}$.

A solução brasileira, embora tenha uma inspiração remota na fluid recovery encontrado nas class actions norte-americanas ${ }^{86}$, acaba por se distanciar dele em sua disciplina, pois é característica daquele instituto a aplicação do produto da condenação em alguma providência estabelecida no caso concreto que mais se aproxime à recomposição do direito violado. Trata-se da aplicação do princípio de assegurar à classe o equivalente à tutela específica, uma idéia que não é estranha ao direito processual brasileiro, mas que é caracterizada por uma grande margem de discricionariedade do juiz na determinação da medida mais próxima à recomposição individual do patrimônio de cada membro da classe. Esse objetivo é deixado de lado pelo sistema brasileiro, que se ocupa de assegurar a responsabilização do réu pela integralidade do dano causado, mas entrega à administração

\footnotetext{
${ }^{85}$ ARAÚJO FILHO, Luiz Paulo da Silva. Ações coletivas: a tutela jurisdicional dos direitos individuais homogêneos, cit., p. 110; ZAVASCKI, Teori. Processo coletivo: tutela de direitos coletivos e tutela coletiva de direitos, cit., p 187-188.

${ }^{86}$ A fluid recovery é um dos meios de recomposição de lesões de massa arbitrados judicialmente segundo um instituto da equity que penetrou no direito norte-americano por via do direito sucessório, o cy-prés. Essa expressão, que consiste em uma forma abreviada do francês aussi près comme possible ("tão aproximado como possível"), designa a possibilidade de que o juiz converta substancialmente o objeto de uma disposição de última vontade quando o cumprimento específico do encargo se mostrar impossível. Traduzido para o processo coletivo, o cy-près passou a identificar a técnica pela qual os juízes passaram a criar formas de reparação aproximada do dano, na impossibilidade de direcionamento da condenação a cada um dos membros da classe. Uma dessas hipóteses é a de que os membros da classe não sejam identificáveis em razão da fluidez do grupo representado, como os usuários de serviço de táxi. A fluid recovery consiste na criação de meios de recomposição que visem a beneficiar a mesma classe lesionada, mas não necessariamente a mesmas pessoas, como, por exemplo, a determinação da redução obrigatória de tarifas do serviço durante um período de tempo determinado. Vide, a propósito, o artigo de KARAS, Stan. The role of fluid recovery in consumer protection litigation: Kraus v. Trinity Management Services. California Law Review, n. 959, May 2002. Por outro lado, LUIZ GUILHERME PENNACCHI DELLORE, estudando a fluid recovery e outros institutos relacionados à class action, conclui que o instituto norteamericano que mais se aproxima dos fundos criados pela lei brasileira é o Cercla Superfund, fundo administrativo vinculado à defesa do meio ambiente (Fundo federal de reparação de direitos difusos: aspectos atuais e análise comparativa com institutos norte-americanos. Revista de Direito Ambiental, São Paulo, n. 38, p. 124-139, 2005).
} 
pública o exame de conveniência e oportunidade da aplicação dos recursos amealhados com a execução coletiva, segundo objetivos mais gerais de ação governamental.

Evidentemente, essa discricionariedade não é absoluta, porque os fundos especiais são um instituto de direito financeiro pelo qual se estabelecem contas segregadas do orçamento geral de direito público, de modo vincular sua aplicação apenas naquelas finalidades determinadas pela lei ${ }^{87}$. Em artigo de 2008, ARTHUR BADIN, ex-presidente do Conselho Gestor do Fundo Federal de Direitos Difusos, defendeu a superioridade da solução brasileira, especificamente naquilo que institui um fundo cuja gestão e aplicação são entregues ao Poder Executivo, que teria melhor capacidade institucional para aplicar os recursos de maneira eficiente, se comparado às fórmulas de recomposição fluída construídas judicialmente segundo a fórmula do cy-près $^{88}$. Pela via da ação coletiva, assim, o que se verifica é uma insuspeitada aproximação do processo coletivo com o direito administrativo. A condenação acaba por se trasmudar em receita pública, revertida a fundo orçamentário de destinação específica (exceto no caso de ação relacionada ao mercado de capitais, em que a condenação se converterá em receita ordinária da União, nos termos do art. $2^{\circ}, \S 2^{\circ}$ da Lei $n^{\circ} 7.913 / 89$ ), e assim assume uma grande afinidade com a multa do direito administrativo sancionador.

\subsection{A legitimação para a causa na ação coletiva e nas ações complementares}

Os interesses individuais homogêneos se caracterizam por sua dispersão na sociedade entre indivíduos que não estão unidos por nenhum propósito em comum, como consumidores, locatários, trabalhadores, contribuintes, usuários de serviços públicos etc. Para que se faça possível a sua defesa coletiva, é necessária a sua organização por alguém que se disponha a preparar a ação judicial em nome de toda a coletividade interessada - um

\footnotetext{
${ }^{87}$ Segundo o art. 71 da Lei $n^{\circ} 4.320 / 64$, que estabelece as normas gerais de direito financeiro aplicáveis à União, Estados e municípios, "constitui fundo especial o produto de receitas especificadas que por lei se vinculam à realização de determinados objetivos ou serviços, facultada a adoção de normas peculiares de aplicação".

88، A análise institucional comparativa feita acima entre os sistemas brasileiro e americano demonstra sobeja vantagem do primeiro, mormente em relação à transparência e accountability na aplicação dos recursos, à permeabilidade ao controle social, à possibilidade de formulação de uma política pública de defesa dos interesses difusos e coletivos mais eficiente e que não leve em consideração apenas realidades locais ou regionais, à estrutura técnica para aplicar e fiscalizar a aplicação dos recursos, à economicidade e avaliação sistemática dos resultados dos projetos apresentados." BADIN, Artur. O fundo de defesa dos direitos difusos. Revista de Direito do Consumidor, São Paulo, v. 67, jul./set. 2008.
} 
"autor ideológico", na expressão da doutrina ${ }^{89}$ - e levá-la a juízo, no interesse dessas pessoas. Ou seja, o ordenamento processual teve de dotar essas pessoas de poderes para deduzir a demanda no interesse das partes ausentes, independentemente de uma autorização expressa, rompendo com a idéia de que apenas os respectivos titulares têm condições de decidir acerca da conveniência e oportunidade de exercitarem as pretensões que decorram da violação de seus direitos. Dessa forma, a legitimação processual foi $o$ primeiro e mais importante obstáculo a ser vencido para que se fizesse possível a tutela coletiva de direitos individuais ${ }^{90}$.

Diferentes soluções foram propostas para esse problema: a atribuição da titularidade da ação a entes governamentais (não apenas as pessoas de direito público, mas também órgãos especializados em defesa do consumidor, o Ministério Público, o ombudsman etc.); a organizações privadas como associações civis voltadas à proteção de interesses da coletividade, partidos políticos e sindicatos; ou mesmo qualquer indivíduo que se apresente como representante da classe. Na medida em que cada tipo de sistema apresenta vantagens e desvantagens, tem sido apontada a preferência por esquemas amplos de legitimação para a causa, que combinem todas essas técnicas: é a orientação que foi adotada pelo Código de Defesa do Consumidor, que excluiu apenas a legitimação do indivíduo.

Há divergência na doutrina sobre a natureza da legitimação para se atuar em nome dos titulares dos direitos individuais com projeção coletiva. NELSON NERY JUNIOR, por exemplo, critica a postura de se estudar o processo coletivo a partir dos conceitos do processo civil comum e, de maneira específica, a aferição da legitimidade processual a partir da titularidade do direito material contido na demanda, para concluir que a legitimidade ad causam do autor coletivo deve ser compreendida sob a perspectiva da selbstäntige Prozeßfürungsbefugnis, a legitimação autônoma para a condução do processo

\footnotetext{
${ }^{89}$ MAURO CAPPELLETTI, que atribui o termo a LOUIS JAFFE, o adota com as seguintes considerações: "O Kampf ums Recht não é mais a luta solitária por um direito subjetivo de Tício contra a violação perpetrada por Caio, mas é, sobretudo, a luta de classes e de categorias, das quais a parte em Juízo não é o ocasional - se bem que qualificado - defensor ou porta-voz mas, exatamente, o representante ideológico" (Formações sociais e interesses coletivos diante da justiça civil. Revista de Processo, São Paulo, n. 5, p. 128, jan./mar. 1977).

${ }^{90} \mathrm{~A}$ estrutura básica dos direitos individuais homogêneos e a possibilidade de sua proteção jurisdicional já eram reconhecidas pelo ordenamento jurídico; ao contrário do que se passou com os interesses difusos e coletivos, cuja proteção jurisdicional teve de ser precedida pelo desenvolvimento da idéia de admissibilidade da tutela de interesses não redutíveis ao esquema do direito subjetivo. Como registra RODOLFO DE CAMARGO MANCUSO, o ordenamento jurídico "vai substituindo a tradicional condição legitimante titularidade do interesse pelo critério mais elástico da sua relevância social, esquema complementado pela exigência da adequada representação por parte de quem se apresente em nome daqueles interesses" (Titularidade do direito, legitimação para agir e representação processual. Revista dos Tribunais, São Paulo, n. 771, jan. 2000).
} 
da doutrina alemã ${ }^{91}$. A crítica de NERY JUNIOR se liga ao fato de que a titularidade dos interesses coletivos e difusos não pode ser atribuída a pessoas (sujeitos de direito), mas apenas a coletividades, e às dificuldades que essa circunstância gerou para que se admitisse inicialmente a viabilidade jurídica de sua tutela jurisdicional nos primeiros estágios do desenvolvimento desse ramo processual. ANTONIO GIDI levou a proposta ainda mais longe, complementando-a com a idéia de autonomia dos interesses individuais homogêneos, desde que coletivamente considerados e titularizados por uma comunidade, frente aos próprios interesses dos indivíduos que compõem o conjunto de vítimas ${ }^{92}$. Esse interesse em abstrato da coletividade, resultado de uma ficção legal, teria como legitimados ordinários apenas aqueles entes escolhidos pela lei. Entretanto, tal construção acaba por dissociar artificialmente a porção homogênea, objeto da ação coletiva, da integralidade dos direitos individuais para cuja tutela se dirige afinal o procedimento repartido.

Parece-nos ter razão DonALDo ARMELIN ao afirmar que, ontologicamente, a Prozeßführungsrecht (direito de conduzir o processo) consiste exatamente na mesma coisa que a legitimação extraordinária, na modalidade de substituição processual. Segundo o autor, foi apenas uma concepção mais restrita da legitimidade processual que ensejou a elaboração do conceito na Alemanha, na medida em que o que se buscava era contornar uma dificuldade própria do direito processual civil daquele país: o fato de que a ausência de legitimidade conduz à improcedência da demanda, com formação de coisa julgada, ao

\footnotetext{
${ }^{91}$ Eis a conhecida passagem do professor da PUC-SP: "Parcela da doutrina ainda insiste em explicar o fenômeno da tutela jurisdicional dos interesses e direitos difusos pelos esquemas ortodoxos do processo civil. Tenta-se justificar a legitimação do Ministério Público, por exemplo, como extraordinária, identificando-a com o fenômeno da substituição processual. $\mathrm{Na}$ verdade, o problema não deve ser entendido segundo as regras de legitimação para a causa, com as inconvenientes vinculações com a titularidade do direito material invocado em juízo, mas sim à luz do que na Alemanha se denomina legitimação autônoma para a condução do processo (selbstäntige Prozeßfürungsbefugnis), instituto destinado a fazer valer em juízo os direitos difusos, sem que se tenha de recorrer aos mecanismos de direito material para explicar referida legitimação." (NERY JUNIOR, Nelson. Princípios do processo na Constituição Federal. 10. ed. São Paulo: Ed. Revista dos Tribunais, 2010. p. 196-197).

${ }^{92}$ De fato, a construção de ANTONIO GIDI, que aparta completamente a noção de interesse individual homogêneo - coletivamente considerado e imputado diretamente à coletividade - do direito material subjacente, por meio da idéia de que a lei criou uma "ficção de direito" para fins de viabilizar a tutela coletiva, necessariamente conduz à conclusão de legitimação ordinária do grupo: "É imperativo observar que, ao contrário do que se costuma afirmar, não são vários, nem indeterminados, os titulares (sujeitos de direito) dos direitos difusos, coletivos ou individuais homogêneos. Há apenas um único titular - e muito bem determinado: uma comunidade no caso dos direitos difusos, uma coletividade no caso dos direitos coletivos ou um conjunto de vítimas indivisivelmente considerado no caso dos direitos individuais homogêneos. (...) O indivíduo, isolada e atomizadamente, aí sim, é portador tão-só e exclusivamente de um 'interesse' não tutelado pelo ordenamento de que o direito superindividual ou individual homogêneo da comunidade ou coletividade à qual pertence seja tutelado em juízo através de uma ação coletiva. Quem tem o direito público subjetivo à prestação jurisdicional referente a tais direitos (direito de ação coletivo) é apenas a comunidade ou a coletividade como um todo, através das entidades legalmente legitimadas a sua propositura." (Coisa julgada e litispendência em ações coletivas, cit., p. 23, g.n.).
} 
passo que o direito de conduzir o processo foi concebido como um pressuposto processual subjetivo que não inibiria a propositura de um novo processo ${ }^{93}$. Como no direito brasileiro a falta de legitimação ad causam gera os efeitos da carência de ação, com a única consequiência de impedir a análise do mérito (art. 267, inc. VI, do CPC), basta-nos o conceito de legitimidade extraordinária para a determinação da disciplina jurídica da atuação dos autores coletivos. Legitimidade extraordinária é toda aquela que constitui exceção à regra do artigo $6^{\circ}$ do Código de Processo Civil, pela qual a defesa em juízo das diversas pretensões cabe àqueles que se afirmam seus titulares, a partir da estrutura do direito material que constitui fundamento da demanda. Como os titulares do interesse individual homogêneo podem estar ausentes do processo, e no geral estarão (apesar da faculdade de nele atuarem, nos termos do art. 104 do CDC), o caso é também de substituição processual. $^{94}$

De acordo com o artigo 82 do Código de Defesa do Consumidor, a legitimidade para promover a ação coletiva de responsabilidade pelos danos individualmente sofridos cabe, de forma concorrente e "disjuntiva" 95 , ou seja, independente, ao Ministério Público; à União, aos Estados, aos Municípios e ao Distrito Federal; às entidades e órgãos da administração pública, direta ou indireta que, mesmo sem personalidade jurídica, sejam especificamente destinados à defesa dos interesses e direitos protegidos pelo Código; às

\footnotetext{
93،A tônica da doutrina alemã é, pois, considerar o direito de conduzir o processo como equiparado à substituição processual, remarcando, porém, a sua distinção relativamente à legitimidade ad causam, distinção essa com reflexos práticos consideráveis. Efetivamente, segundo Rosenberg e Lent, a carência da legitimidade ad causam implica improcedência do pedido, ao passo que a ausência do direito de conduzir o processo resulta na inadmissibilidade da ação, de vez que este configura verdadeiro pressuposto processual. Inexistindo, em nosso sistema jurídico processual, essa distinção de ordem prática, efetivamente relevante, a aceitação da elaboração doutrinária de torna despicienda (...). Assim, o chamado Prozessführungsrecht, dentro do enfoque deste trabalho, não passa de uma espécie da legitimidade considerada genericamente, espécie essa de natureza excepcional, que lhe justifica a denominação de legitimidade extraordinária. Não pode, portanto, esse instituto ser considerado como afim da legitimidade, mas, pura e simplesmente, uma de suas espécies." (ARMELIN, Donaldo. A legitimidade para agir no direito processual civil brasileiro. São Paulo: Ed. Revista dos Tribunais, 1979. p. 107, g. n.) Cabe ressaltar que a Alemanha conta com uma ação coletiva de titularidade das associações civis (a "Verbandskage"), voltada à defesa de interesses indivisíveis.

${ }^{94}$ No mesmo sentido: GRINOVER, Ada Pellegrini et al. Código Brasileiro de Defesa do Consumidor comentado pelos autores do anteprojeto, cit., p. 869.

${ }^{95}$ CARLOS ALBERTO DE SALLES sustenta que o modelo de legitimação para a defesa de interesses coletivos da lei brasileira não é realmente misto, mas preponderantemente estatal e subsidiariamente organizacional, em razão dos instrumentos conferidos ao Ministério Público para promover as ações coletivas (garantias institucionais, inquérito civil público) e falta de incentivos para as organizações privadas, que tendem a perseguir um efeito carona (free-riding) na atuação do órgão público. (SALLES, Carlos Alberto de. Políticas públicas e legitimidade para a defesa de interesses difusos e coletivos. Revista de Processo, São Paulo, n. 121, p. 47-48, mar. 2005). RODOLFO DE CAMARGO MANCUSO, embora elogie a abertura "pluralista" da legitimação processual na lei brasileira, expõe de maneira detalhada o acento marcadamente estatal na iniciativa do processo coletivo na prática brasileira (Ação civil pública: em defesa do meio ambiente, do patrimônio cultural e dos consumidores. 12. ed. São Paulo: Ed. Revista dos Tribunais, 2011. p. 182-190).
} 
associações legalmente constituídas há pelo menos um ano e que incluam entre seus fins institucionais a defesa dos interesses e direitos protegidos pelo Código, das quais se dispensa a autorização em assembléia para promover a demanda.

Vamos nos deter um pouco sobre este assunto, porque o sistema de legitimação para o processo instituído pela Lei n. 8.078/90 exerce grande influência sobre o regime da coisa julgada, especialmente naquilo que diz respeito à ineficácia de efeitos processuais negativos sobre a esfera dos indivíduos interessados. A legitimidade processual, definida pela técnica do Código de Processo Civil como uma das condições da ação $\left(\operatorname{artigo~} 3^{\circ}\right.$ ), consiste essencialmente na capacidade de vincular eficazmente o titular do interesse material aos resultados do processo ${ }^{96}$. Se a conduta da parte processual for completamente ineficaz perante os direitos sobre os quais se discute, por uma questão de economia, o processo deve ser extinto sem análise do mérito (artigo 267, inciso VI). O sentido de estabelecer a legitimidade ad causam como condição da ação está na possibilidade de extinguir desde logo o processo cuja sentença final não poderá obrigar os titulares da relação jurídica controvertida. A sentença, nessa eventualidade, teria as características de mero parecer, e para isso não se justificaria a movimentação do aparato jurisdicional.

Assim, na base de toda regra de legitimação processual sempre se encontra uma determinada situação legitimante, isto é, uma especial relação entre a pessoa a quem se confere a titularidade de direito de demandar e o interesse a ser por ela encampado. Nos casos de legitimação ordinária, em que o titular do direito de ação é o titular do interesse, a situação legitimante proporciona eficácia plena aos atos praticados pelo próprio interessado, podendo ele livremente conduzir a causa e dispor sem qualquer limitação do direito discutido em juízo. Por outro lado, na legitimação extraordinária, em que o poder de deduzir a ação em juízo é atribuído a quem não é o titular do interesse, a extensão dos poderes processuais tende a acompanhar a intensidade do vínculo se apresenta como situação legitimante. Embora o assunto aceite alguma conformação pela política legislativa, a cláusula constitucional do devido processo legal restringe a margem de ação do legislador, de modo que a vinculação de terceiros ao resultado do processo,

\footnotetext{
${ }^{96}$ É o que demonstra DONALDO ARMELIN em sua excelente monografia sobre o tema, em que se parte da análise da legitimidade em geral, sob a ótica dos planos da existência, validade e eficácia, para aplicar os resultados alcançados no plano processual: "A ausência de legitimidade importa ineficácia do ato, não se confundindo validade com ineficácia (...) resulta a legitimidade, que supõe a capacidade, como a idoneidade do sujeito para a prática de determinado ato ou para suportar seus efeitos, emergente em regra da titularidade de uma relação jurídica ou de uma situação de fato com efeitos jurígenos, asseguradora da plena eficácia desse mesmo ato, e, pois, da responsabilidade pelos seus efeitos, relativamente àqueles atingidos por estes”. (A legitimidade para agir no direito processual civil brasileiro, cit., p. 13).
} 
especialmente aqueles prejudiciais, somente podem ser consideradas compatíveis com a Constituição se houver situações legitimantes que o justifiquem satisfatoriamente.

Nesse sentido, a solução norte-americana permite uma ampla extensão da coisa julgada frente à classe representada porque os critérios de legitimação são rígidos, aferidos caso a caso segundo o teste da representatividade adequada do autor coletivo e dos advogados que compõem o seu conselho de patrocínio. Por isso ANTONIO GIDI afirma que "o requisito da adequação do representante tem um duplo aspecto. Por um lado, é o direito de todos os membros ausentes de terem os seus interesses adequadamente representados na ação coletiva. Por outro, é o direito de não serem atingidos pela coisa julgada de uma sentença dada em uma ação em que os seus interesses não foram adequadamente representados"97. De igual maneira, MÁRCIO FLÁVIO MAFRA LEAL explica que "a construção da doutrina da representação adequada baseia-se em uma forma de obedecer a ela [n.a.: à cláusula do devido processo legal]: estando os interesses dos ausentes representados de forma justa, adequada tecnicamente (referindo-se às habilidades do procurador), sendo, enfim, esta de qualidade inquestionável, é possível a extensão da coisa julgada, vez que apenas formalmente o representado não está na relação processual, mas seus interesses estão" $"$.

O sistema adotado pela lei brasileira, de outro lado, optou por situações legitimantes em que o nexo que liga os autores coletivos e a classe representada pode tanto ser efetivo como também muito tênue, na medida em que daqueles se exige apenas o preenchimento de requisitos formais, que são aferidos pelo juiz apenas pelo exame de seus documentos constitutivos (no caso das associações civis e sindicatos) ou de sua qualidade institucional (no caso de entes públicos personalizados ou despersonalizados, como o Ministério Público e os órgãos do Sistema de Defesa Nacional do Consumidor). A lei não se preocupa em exigir uma investigação fática mais profunda em torno de sua efetiva atuação do autor coletivo em prol dos interesses defendidos ${ }^{99}$. É certo que parte da doutrina entende que existe um controle da adequação da representação também no direito

\footnotetext{
${ }^{97} \mathrm{GIDI}$, Antonio. A class action como instrumento de tutela coletiva dos direitos: as ações coletivas em uma perspectiva comparada, cit., p. 101.

${ }^{98}$ LEAL, Márcio Flávio Mafra. Ações coletivas: história, teoria e prática. Porto Alegre: Sérgio Antonio Fabris Editor, 1998. p. 90.

${ }^{99}$ Nas palavras de JOSÉ MARCELO MENEZES VIGLIAR, “esse sistema cria um compromisso estatutário e legitima a associação pela observância de uma cultura cartorária: haverá representatividade adequada, mesmo que, na prática, não exista compromisso com a causa defendida em gênero, apenas porque há um estatuto registrado! É lamentável, mas viável: (...)" (Interesses individuais homogêneos e seus aspectos polêmicos. 2. ed. São Paulo: Saraiva, 2008. p. 75).
} 
brasileiro, mas ainda assim reconhecendo que se trata de um controle fraco e eminentemente formal, limitado ao exame das finalidades institucionais dos órgãos públicos e aos objetivos estatutários das associações civis legitimadas ${ }^{100}$. Por isso, a atuação desses legitimados somente pode vincular eficazmente os substituídos dentro de certos limites, que impedem a disposição dos direitos individuais.

O ponto positivo da escolha feita pelo legislador consiste no fato de que há uma abertura muito grande ao ajuizamento de ações coletivas, de modo que a legitimidade não é um fator impeditivo a que as instituições a priori reconhecidas como objetivamente capazes de promover a demanda coletiva, dentro espectro de seus respectivos fins institucionais, demandem em nome de grupos a defesa coletiva de seus interesses ${ }^{101}$. Contudo, esse mecanismo se reflete em uma atuação sensivelmente limitada pelos legitimados coletivos, que em nenhuma hipótese pode refletir em efeitos negativos para os representados, e que talvez seja responsável por uma certa banalização do instituto.

A conduta do autor coletivo, de qualquer forma, somente é admitida para atos que possam beneficiar os substituídos. Isso produz resultados que são muitas vezes criticados pela doutrina, como a natureza secundum eventum litis da coisa julgada, que sujeita o réu a responder por uma pluralidade de demandas individuais mesmo após a vitória na ação coletiva; ou a impossibilidade de que o legitimado coletivo celebre transação para extinguir

\footnotetext{
${ }^{100}$ Esse controle de representatividade adequada atenuado se circunscreveria à verificação da "pertinência temática" entre o objeto da ação coletiva e as finalidades institucionais do órgão ou associação, sem se aprofundar na experiência ou capacidade do autor para defender de forma vigorosa o interesse coletivo, a exemplo da sistemática da Regra 23 das FRCP/66 (COSTA, Suzana Henriques. O controle judicial da representatividade adequada: uma análise dos sistemas norte-americano e brasileiro. In: SALLES, Carlos Alberto de (Coord.). As grandes transformações do processo civil brasileiro: homenagem ao professor Kazuo Watanabe. São Paulo: Quartier Latin, 2009. p. 953-978). Ou seja, esse tipo de controle ocorreria quando se reconhece que o Ministério Público não pode defender determinados interesses individuais disponíveis sem especial relevância social (CARNEIRO, Athos Gusmão. Ação civil pública - direitos individuais homogêneos, limitações à sua tutela pelo Ministério Público. Revista Síntese de Direito Civil e Processual Civil, Porto Alegre, v. 2, n. 12, p. 5-13, jul./ago. 2001), que a associação civil não tem legitimidade para encampar determinada pretensão quando houver conflito interno de interesses entre os associados, ou que a associação de consumidores não pode discutir matéria tributária, por exemplo. Dado o pouco espaço aberto à aferição da adequação da representatividade, ADA PELLEGRINI GRINOVER, mesmo entendendo que o sistema, antes de vedar, recomenda a aferição desse requisito, conclui no sentido de que não seria possível a adoção de uma coisa julgada pro et contra em interesses individuais homogêneos, sob o atual regime de legitimação para a causa (A coisa julgada. In: GRINOVER, Ada Pellegrini et al. Código Brasileiro de Defesa do Consumidor comentado pelos autores do anteprojeto, cit., p. 905-907). Admitindo de forma mais ampla o controle da adequação do representante, a partir do princípio do devido processo legal: GIDI, Antonio. A class action como instrumento de tutela coletiva dos direitos: as ações coletivas em uma perspectiva comparada, cit., p. 133-135.

${ }^{101}$ Entretanto, essa abertura não correspondeu a uma ampla utilização das ações coletivas por todos os legitimados, sendo que diversas circunstâncias - desde a falta de aparelhamento dos demais órgãos estatais, até falta de recursos das associações privadas - concorreram para a concentração do ajuizamento nas mãos do Ministério Público (MANCUSO, Rodolfo de Camargo. A projetada participação eqüânime dos colegitimados à propositura da ação civil pública: da previsão normativa à realidade forense, cit.).
} 
mais rapidamente o litígio ${ }^{102}$, já que ele não pode dispor do direito individual que ele promove em juízo ${ }^{103}$.

Exatamente por essa razão, o regime de legitimação para os processos individuais complementares difere daquele para as ações coletivas. Essas ações são tratadas como ações autenticamente individuais, e, assim, devem ser promovidas diretamente pelos próprios interessados ${ }^{104}$. Excepcionalmente, podem as associações civis promover tais ações e figurarem como partes em juízo, mas para isso devem contar com expressa outorga de poderes por ato de vontade de cada indivíduo, agindo como representantes e não como substitutas processuais dos indivíduos a quem pertence o interesse deduzido em juízo ${ }^{105}$. É o que prevê o texto constitucional no seu artigo $5^{\circ}$, inciso XXI (“as entidades associativas,

${ }^{102}$ VIGLIAR, José Marcelo Menezes. Interesses individuais homogêneos e seus aspectos polêmicos, cit., p. 164-165.

${ }^{103}$ Sob esse aspecto, o autor da demanda coletiva que tem por objeto a tutela de direitos individuais tem ainda menos poderes do que o autor da ação civil pública que tenha por objeto os direitos transindividuais de natureza indivisível. Isto ocorre na medida em que os bens coletivos admitem a disposição por parte de determinados legitimados coletivos, senão em seu núcleo essencial, ao menos na maneira de sua efetivação (MANCUSO, Rodolfo de Camargo. Ação civil pública: em defesa do meio ambiente, do patrimônio cultural e dos consumidores, cit., p. 279). Os termos de ajustamento de conduta e instrumentos similares, a que o Ministério Público, as pessoas de direito público e autarquias especializadas como o CADE ou IBAMA estão autorizados a celebrar, em suas respectivas áreas de competência, bem demonstram esse ponto. Registre-se a posição de CAMILO ZUFELATO, que admite a possibilidade de serem firmados acordos in utilibus, dos quais possam se beneficiar os substituídos, mas que não lhes impeçam de discutir os termos do ajuste em juízo (Coisa julgada coletiva, cit., p. 452-461).

${ }^{104}$ Em sentido contrário, FREDIE DIDIER Jr. e HERMES ZANETI Jr. entendem que "os entes legitimados à tutela coletiva tem legitimação tanto para certificar quanto para efetivar direitos" (Curso de direito processual civil: processo coletivo, cit., v. 4, p. 399). O posicionamento, embora minoritário na doutrina, ganhou força com o julgamento do Recurso Extraordinário 210.029 pelo Supremo Tribunal Federal, em que aquela corte decidiu que os sindicatos (apenas eles) têm poderes para executar a sentença coletiva. Esse julgamento será examinado mais adiante neste trabalho.

${ }^{105}$ Este ponto é enfatizado por TEORI ALBINO ZAVASCKI ao descrever o procedimento da ação civil coletiva: "a fórmula alternativa do procedimento especial ora examinado adota um duplo regime: na primeira fase, a da ação coletiva propriamente dita, a demanda é promovida mediante substituição processual (=a tutela é requerida por quem não é titular do direito afirmado, em favor de quem o é); e, na segunda fase, a da ação de cumprimento, o regime é o de representação (o titular do direito postula em nome próprio o cumprimento, em seu favor, da sentença genérica do procedimento da ação coletiva." Prossegue afirmando ser lógico e natural que "na ação de cumprimento, da segunda fase, na qual a cognição judicial dirige seu foco aos aspectos particulares e individuais dos direitos subjetivos, sejam os próprios interessados os autores da demanda" (Processo coletivo: tutela de direitos coletivos e tutela coletiva de direitos, cit., p. 153). No mesmo sentido, anota ADA PELLEGRINI GRINOVER que "aqui, as pretensões à liqüidação e execução da sentença serão necessariamente individualizadas: o caso surge como de representação, devendo os entes e pessoas numeradas agirem em nome das vítimas e sucessores. Por isso, parece faltar ao Ministério Público legitimação para a liqüidação e execução individual, em que se trata da defesa de direitos individuais disponíveis, exclusivamente" (Código Brasileiro de Defesa do Consumidor comentado pelos autores do anteprojeto, cit., p. 887). O fundamento para isso, como registra LUIZ PAULO DA SILVA ARAÚJO FILHO, está em que "não se pode reconhecer uma esdrúxula capitis diminutio dos titulares dos direitos individuais. Ao revés, a atuação das associações e dos sindicatos não pode prejudicar ou empecer o poder da vontade dos titulares dos direitos subjetivos, mesmo porque, não se pode esquecer, a legitimação extraordinária, em princípio, não importa a 'expropriação do poder de disposição e faculdade de valoração do substituído" (Ações coletivas: a tutela jurisdicional dos direitos individuais homogêneos, cit., p. 103-104). 
quando expressamente autorizadas, têm legitimidade para representar seus filiados judicial ou extrajudicialmente"). A outorga de poderes de representação para a execução deve ser comprovada nos autos por juntada de procuração, que é o instrumento que faz a prova desse negócio jurídico, em que seja especificamente declarada a finalidade (artigos 653 e 661, $\S 1^{\circ}$, do Código Civil). Em outras palavras, a legitimidade extraordinária do substituto processual compreende apenas o poder de promover a demanda tendente à obtenção da sentença genérica, e não se estende à fase seguinte, em que processos individuais complementares terão por objeto a habilitação das vítimas e liqüidação de seus créditos.

A explicação para isso está no fato de que em um grau menos intenso na liqüidação, mas especialmente relevante na execução, o processo resulta na disposição do interesse deduzido em juízo e gera riscos de prejuízos para o seu titular, caso a parte processual o conduza de maneira negligente, inábil, ou mesmo fraudulenta. Ao pleitear uma determinada quantia como conteúdo do valor da obrigação, o autor da liqüidação renuncia ao excedente, e o processo ficaria completamente desprovido de significado se isso não vinculasse o titular do direito. E na execução, seja qual for o valor executado, é assegurado ao devedor que paga o direito à quitação que o exonere definitivamente do vínculo obrigacional (art. 319 do Código Civil). Em ambas as hipóteses o titular do direito poderia ser prejudicado ou pela conduta em juízo do substituto processual, ou então pela eventualidade de que este deixasse de repassar os valores levantados ou viesse a exigir taxas abusivas para fazê-1o ${ }^{106}$.

Para que a lei pudesse permitir a autores coletivos pleitearem também a execução em nome da classe representada, ou para que a coisa julgada pudesse ser eficaz independentemente do resultado do processo (pro et contra), de maneira compatível com a cláusula geral do devido processo legal, seria necessário modificar o sistema de legitimação para a causa, para que somente estivesse habilitado a atuar em juízo em nome de um grupo de pessoas aquele que estivesse em uma situação legitimante caracterizada

\footnotetext{
${ }^{106}$ A Primeira Turma do Superior Tribunal de Justiça, ao julgar o recurso especial $\mathrm{n}^{\mathrm{o}}$ 766.134-DF, anulou execução promovida por federação sindical de hospitais contra a Fazenda Pública, manifestando o entendimento de que o substituto processual não tem crédito próprio a executar e a execução da indenização destinada à integralidade da classe importaria em enriquecimento ilícito da entidade. Ficou ali firmado que "tratando-se de execução decorrente de ação coletiva, a falta de individualização dos créditos importa em nulidade da execução, para evitar duplicidade no pagamento da indenização, haja vista que as empresas filiadas não encontram vedação para ajuizar ações individuais sobre o mesmo crédito, sendo curial que várias das empresas já ajuizaram ações em relação aos mesmos valores aqui questionados. (...) Se consumada a execução, a Federação recorrida poderá levantar o produto da condenação ficando a própria instituição com a responsabilidade de instaurar concurso de credores para o pagamento dos substituídos, o que representaria, em verdade, enriquecimento ilícito em favor da recorrente." (relator Ministro FRANCISCO FALCÃO, julgado em 15.05.2008, publicado no DJe de 27.08.2008).
} 
por estreitos vínculos com a classe e reconhecida capacidade de atuar em prol de interesses alheios, aproximando-se da aferição judicial da representatividade adequada do modelo norte-americano. Este tipo de reequilíbrio dependeria de um juízo essencialmente político: a possibilidade de promover uma ação coletiva ficaria mais restrita, mas de outro lado seria reconhecida uma maior eficácia à atuação do substituto processual.

A exceção às considerações que fizemos sobre a ausência de legitimidade do autor coletivo para promover as ações individuais de liqüidação e execução está no entendimento adotado pelo Supremo Tribunal Federal acerca da existência de legitimação dos sindicatos para a execução de verbas trabalhistas, em substituição processual, ao interpretar o artigo $8^{\circ}$, inciso III da Constituição de 1988 ("ao sindicato cabe a defesa dos direitos e interesses coletivos ou individuais da categoria, inclusive em questões judiciais ou administrativas"). Na oportunidade do julgamento do recurso extraordinário $\mathrm{n}^{\mathrm{o}} 210.029^{107}$, o tribunal decidiu que, dada a institucionalização dos sindicatos e a desproporção de forças entre empregadores e empregados, eles deteriam a capacidade para praticar atos de disposição em nome e por conta do titular do direito trabalhista, podendo promover também a execução em regime de substituição processual. A decisão, com a vênia devida, nos parece incompatível com o caráter privado dos créditos individuais, na medida em que o direito de disposição (ius abutendi) integra o núcleo do direito de propriedade dos filiados. A proteção constitucional da propriedade, que é um direito fundamental negativo, se consubstancia em um dever geral de abstenção oponível contra quaisquer ingerências externas (inclusive por parte dos sindicatos). Por isso, malgrado a maior institucionalização das entidades sindicais em relação às associações civis, é certo que o nexo que liga essas entidades aos filiados na maioria das vezes não é efetivo, de modo que não existe situação legitimante robusta o suficiente para autorizar que aqueles assumam a administração dos interesses dos últimos sem sua autorização ou conhecimento. Aliás, não causa surpresa que a doutrina já relate incidentes relacionados à ausência de repasse dos créditos individuais

\footnotetext{
${ }^{107} \mathrm{O}$ julgamento foi resumido com a seguinte ementa oficial: "PROCESSO CIVIL. SINDICATO. ART. $8^{\circ}$, III DA CONSTITUIÇÃO FEDERAL. LEGITIMIDADE. SUBSTITUIÇÃO PROCESSUAL. DEFESA DE DIREITOS E INTERESSES COLETIVOS OU INDIVIDUAIS. RECURSO CONHECIDO E PROVIDO. $\mathrm{O}$ artigo $8^{\circ}$, III da Constituição Federal estabelece a legitimidade extraordinária dos sindicatos para defender em juízo os direitos e interesses coletivos ou individuais dos integrantes da categoria que representam. Essa legitimidade extraordinária é ampla, abrangendo a liquiidação e a execução dos créditos reconhecidos aos trabalhadores. Por se tratar de típica hipótese de substituição processual, é desnecessária qualquer autorização dos substituídos. Recurso conhecido e provido.” (Plenário, julgado em 02.06.2006, publicado no DJ de 17.08.2007).
} 
levantados por entidades sindicais sem o conhecimento de seus filiados ${ }^{108}$, pois este é o resultado previsível de uma interpretação do Supremo Tribunal Federal que foi, no mínimo, desatenta às repercussões práticas potencialmente lesivas aos trabalhadores vinculados aos sindicatos, e que está a reclamar revisão por parte dos Ministros que o compõem.

\subsection{Relacionamento entre ações individuais e ação coletiva}

No campo do relacionamento entre as ações individuais e a ação coletiva, há duas questões que interessa aqui analisar. A primeira delas se relaciona ao sistema de informações, por meio do qual é dado conhecimento a terceiros juridicamente interessados sobre a existência e o objeto da ação civil coletiva. A segunda consiste no exame das interferências recíprocas que essas ações produzem uma sobre a outra, diante da interpenetração que existe entre os respectivos objetos.

\subsubsection{Das notificações e editais}

Quando da propositura da demanda, determina o artigo 94 do Código de Defesa do Consumidor, "será publicado edital no órgão oficial, a fim de que os interessados possam intervir no processo como litisconsortes, sem prejuízo de ampla divulgação pelos meios de comunicação social por parte dos órgãos de defesa do consumidor".

\footnotetext{
${ }^{108}$ Em artigo destinado a defender que os poderes reconhecidos aos sindicatos pelo RE 210.029 não abrangem o levantamentos de valores ou a prática de outros atos dispositivos, o que nos parece contrariar algo que foi claramente dito - ainda que de maneira infeliz - pelo Supremo Tribunal Federal, o juiz federal ANDRÉ DIAS FERNANDES relata caso de sua experiência profissional: "uma federação sindical propusera ação coletiva postulando diferenças remuneratórias (anuênios) em favor de seus substituídos processuais (servidores públicos federais). O direito foi reconhecido por decisão transitada em julgado. A federação sindical propôs, então, execução das verbas vencidas, sem autorização expressa de seus substituídos. Na fase de conhecimento da ação coletiva, também não houvera juntada de autorização dos substituídos. Ocorre que alguns dos substituídos tiveram suas declarações de Imposto de Renda retidas em malha pela Receita Federal, sob o argumento de haverem recebido precatórios relativos àquela ação coletiva. Esses substituídos processuais ajuizaram, então, ação ordinária requerendo (a) a liberação da restituição de IRPF a que faziam jus, por não terem recebido verba de precatório algum; (b) a condenação da federação sindical e do escritório de advocacia ao pagamento de danos morais; e (c) a devolução à União dos valores indevidamente recebidos, visto que efetuaram o levantamento dos valores dos precatórios em nome dos substituídos, sem autorização nem ciência destes, e não lhes repassaram os valores levantados, apesar de decorridos dois anos dos saques. De fato, os valores foram recebidos não pelos substituídos na ação coletiva, mas pelo advogado da ação. O substituído estava, pois, sofrendo duplo prejuízo: além de não receber a verba a que fazia jus, estava sendo compelido pela Receita Federal a pagar Imposto de Renda sobre ela." (Limites imanentes à substituição processual na fase de cumprimento das ações coletivas. Revista Síntese de Direito civil e Processual Civil, Porto Alegre, n. 73, p. 87, set./out. 2001).
} 
Há diversos questionamentos que podem ser feitos ao regime de notificações dirigidas à sociedade, no procedimento da ação civil coletiva. O primeiro deles diz respeito à finalidade da publicação, que é voltada à intervenção de interessados individuais como litisconsortes na ação coletiva. Isto porque a intervenção do indivíduo na fase coletiva é, reconhece-se hoje, algo indesejado no procedimento da ação coletiva. E isto tanto do ponto de vista individual, porque ao ingressar como parte no processo ele se sujeita a uma coisa julgada desfavorável que normalmente não o prejudicaria ${ }^{109}$, como do ponto de vista coletivo, porque a introdução de questões individuais em uma demanda voltada à solução de questões comuns acabaria por criar atrasos no procedimento, especialmente se fosse grande o número de indivíduos que viesse a atender a notificação: daí o entendimento de que a intervenção na ação coletiva não permite a ampliação de seu objeto, para nele incluir questões de interesse particular do interveniente ${ }^{110}$.

É incongruente, de outro lado, que no momento em que seria mais necessário dar ampla publicidade à sentença, isto é, o momento posterior ao trânsito em julgado da sentença genérica, a lei não faça nenhuma parecida, resultado de um irrefletido veto presidencial ao artigo 96, que previa que "transitada em julgado a sentença condenatória, será publicado edital, observado o disposto no art. 93"111. A previsão de notificação efetiva aos potenciais lesados seria de grande importância, sobretudo, nessa ocasião, porque o Código de Defesa do Consumidor, ao mesmo tempo, estabeleceu um prazo relativamente curto para habilitação de interessados "em número compatível com a gravidade do dano", antes que a indenização se converta em coletiva e seja revertida ao fundo para reconstituição de bens lesados de que fala o art. 13 da Lei ${ }^{\circ}$ 7.347/85; mas também subordinou a extensão dos efeitos da sentença coletiva ao conhecimento do processo por terceiros, consoante a regra do artigo 104, de modo que essa decadência não pode operar em face de quem não tomou conhecimento da possibilidade de promover a execução

\footnotetext{
${ }^{109}$ Essa circunstância, como diagnosticou BOTELHO DE MESQUITA, “constituirá um poderoso incentivo a que as vítimas não ingressem como litisconsortes na ação que seja intentada por algum dos legitimados do art. 82" (A coisa julgada no Código do Consumidor. In: A coisa julgada. Rio de Janeiro: Forense, 2006. p. 39).

110“(...) o interveniente do art. 94, embora litisconsorte, não poderá apresentar novas demandas, ampliando o objeto litigioso da ação coletiva à consideração de seus direitos pessoais, o que contraria todo o espírito de 'molecularização' da causa." (GRINOVER, Ada Pellegrini et al. Código Brasileiro de Defesa do Consumidor comentado pelos autores do anteprojeto, cit., p. 882).

${ }^{111} \mathrm{O}$ veto a esse dispositivo, como a outros do mesmo texto legal, infelizmente parece não parece ter sido revestido dos cuidados que a importância da matéria tratada pelo Código recomendava. A lacônica justificativa para a supressão do artigo 96 foi a de que "o art. 93 não guarda pertinência com a matéria regulada nessa norma" (Mensagem presidencial $n^{\circ}$ 644, de 11.09.1990). Com a devida vênia, a remissão ao artigo 93 tinha o claro propósito de vincular a publicação dos editais ao foro de competência para processamento da ação civil coletiva.
} 
coletiva. Sem um meio eficaz de notificação dos beneficiários interessados, portanto, na prática a conversão substancial das reparações individuais em coletiva fica impossibilitada.

Outra ordem de questionamentos pode ser dirigida à forma da publicidade. Há que se reconhecer que a publicação de editais em diários oficiais e no "átrio do fórum" é meio que fornece uma publicidade muito restrita, que chega ao conhecimento de pouquíssimas pessoas $^{112}$. Nesse particular, a lei está evidentemente ultrapassada pelo avanço dos meios de comunicação experimentados por nossa sociedade nos últimos vinte anos. Aliás, em tempos em que se discute se seria excessiva exposição de órgãos do poder Judiciários nos meios de comunicação, em que sessões de julgamento dos tribunais são televisionadas em tempo real, e que os órgãos da Justiça contam com assessorias de imprensa especializadas e sítios muito bem estruturados na rede mundial de computadores ${ }^{113}$, a divulgação da existência de uma ação coletiva em diários oficiais é, para se dizer o mínimo, anacrônica. Aliás, o aproveitamento dessa estrutura de comunicação, já existente e comprovadamente eficaz, poderia contribuir de maneira importante para que as ações coletivas fossem efetivamente levadas ao conhecimento dos cidadãos e advogados, sem necessidade de se esperar por mudanças legislativas.

De qualquer forma, muito mais importante do que a divulgação de editais em diários oficiais seria a ampla divulgação, a cargo dos próprios tribunais, dos órgãos de defesa do consumidor ou pelos demais entes exponenciais legitimados à tutela de outros direitos individuais abertos à tutela coletiva, da existência e objeto do processo. No entanto, a lei não estabelece nenhuma obrigatoriedade concreta nesse sentido, de modo que

\footnotetext{
${ }^{112}$ Observou-se que "promove o mencionado dispositivo que os interessados (os destinatários dessa tutela coletiva) sejam noticiados do êxito obtido apenas por intermédio de seus representantes adequados que, de fato, acompanhavam o processo. Tais representantes, na vigente sistemática, não dispõem de mecanismos para levar adiante essa essencial informação. Assim, se o objeto da demanda coletiva não é daqueles que venham a merecer ampla divulgação pela mídia, os interessados, na realidade prática, não tomam conhecimento do resultado da demanda. A lamentável conseqüência é que a tutela não se verifica na prática, especialmente quando veiculada em sentença de mérito de conteúdo genérico que, conforme mencionado, deve submeter-se a prévia liqüidação. Não havendo conhecimento do resultado favorável, a liqüidação não se viabilizará e, via de conseqüência, não haverá título a ser cumprido" (VIGLIAR, José Marcelo Menezes. Interesses individuais homogêneos e seus aspectos polêmicos, cit., p. 125).

${ }^{113}$ O registro é feito por RODRIGO CUNHA LIMA FREIRE: “é interessante notar que o STJ, apesar de não disciplinar normativamente o emprego do e-mail para a prática de atos processuais, possui um primoroso site - a exemplo do STF -, no qual se pode encontrar, entre outros recursos: o sistema push, pelo qual as pessoas previamente cadastradas recebem por e-mail informações a respeito da jurisprudência do Tribunal e dos processos que lhes interessam, as notícias, com informações diversas sobre o Tribunal, inclusive sobre decisões proferidas no mesmo dia, o informativo de jurisprudência, com informações atualizadas sobre os seus julgados, e a revista eletrônica de jurisprudência, que disponibiliza o inteiro teor dos arestos do Tribunal, possibilitando a citação destes como paradigmas, especialmente nos recursos especiais e nos embargos de divergência em recurso especial" (FREIRE, Rodrigo Cunha Lima. O processo civil na sociedade da informação: estudo de um caso. Revista do Instituto dos Advogados de São Paulo, São Paulo, n. 17, jan. 2006).
} 
se o juiz não o exigir no caso concreto, pouca ou nenhuma divulgação haverá do ajuizamento da ação coletiva. Isso tudo nos leva a concluir que o sistema de divulgação da existência e julgamento da ação coletiva é extremamente deficiente, constituindo-se em verdadeiro calcanhar-de-aquiles que determina de maneira importante para a reduzida eficácia do instrumento processual da ação civil coletiva.

\subsubsection{Das interferências recíprocas}

No Código de Defesa do Consumidor se percebe uma orientação muito clara, no sentido de que a tutela coletiva dos direitos individuais homogêneos não deve ser feita em prejuízo das vias individuais direcionadas à tutela das mesmas pretensões. Tendo em vista que há um evidente campo de interpenetração entre os objetos das ações coletivas e individuais, é de importância central no sistema a regulamentação do modo como esses processos interferem uns sobre os outros.

Nessa linha, o artigo 104 da Lei nº 8.078/90 estabeleceu o princípio de que as ações coletivas "não induzem litispendência para as ações individuais, mas os efeitos da coisa julgada erga omnes ou ultra partes a que aludem os incisos II e III do artigo anterior não beneficiarão os autores das ações individuais, se não for requerida sua suspensão no prazo de trinta dias, a contar da ciência nos autos do ajuizamento da ação coletiva”. Há aí alguns aspectos que merecem ser sublinhados.

De fato, não haveria de se falar em litispendência entre ações coletivas e individuais, porque o objeto de ambas é distinto. Se por acaso a ação coletiva consistisse em reunião das pretensões individuais, consideradas integralmente, ela poderia ser considerada como uma hipótese de cúmulo subjetivo de demandas. Mas já vimos que não é assim: a ação coletiva tem objeto próprio, que interessa a todos os membros da classe, mas não se confunde com a pretensão individual de nenhum deles. De continência também não se trata, tendo em vista que o pedido da ação coletiva não é um bem da vida passível de tutela jurisdicional autônoma (ponto este que será aprofundado no último capítulo), e o pedido genérico não é elemento de um pedido complexo ${ }^{114}$.

\footnotetext{
${ }^{114}$ No que diz respeito à continência, é exata a análise de RICARDO DE BARROS LEONEL, para quem "não é razoável afirmar que o pedido na demanda coletiva é 'mais abrangente', nos termos do Código de Processo Civil. Os pedidos são substancialmente diversos: o indivíduo, na sua ação, pretende v.g., o
} 
Como a condenação genérica é preordenada à resolução de uma questão comum, de que depende a decisão das pretensões individuais de ressarcimento, o que tecnicamente se constata existir entre ações coletivas e ações individuais é um vínculo de prejudicialidade externa $^{115}$. As questões prejudiciais, por regra, são conhecidas de maneira incidental no processo, razão pela qual a regra geral do Código de Processo Civil é a de que o processo dependente deve ser temporariamente suspenso enquanto se aguarda a resolução da lide subordinante (artigo 265, inciso IV), sem que haja obstáculo a seu prosseguimento se as causas prejudiciais não forem decididas em tempo razoável. A disciplina introduzida pelo artigo 104 do Código de Defesa do Consumidor, de outro lado, estruturou-se nas premissas de que a existência da ação coletiva com o mesmo objeto deve ser informada nos autos pelo réu, para que então o autor decida - segundo melhor lhe convier - se optará pela suspensão do processo até o julgamento da ação coletiva, ou se prosseguirá em sua ação individual. Neste último caso, apenas, a lei estabelece que ele não possa se beneficiar do que vier a ser decidido na ação coletiva, razão pela qual a manifestação pelo prosseguimento no processo equivalerá à opção de exclusão da classe representada (optout). Caso o réu não informe nos autos da ação individual que responde também a uma ação coletiva, de outro lado, a repercussão disso seria o processamento em paralelo das duas ações, sem que se pudesse imputar ao autor qualquer prejuízo em se beneficiar da sentença genérica que fixasse a obrigação do réu, acaso dela tomasse conhecimento.

Essa última situação, muito comum na prática forense, leva a que o processo coletivo se mostre um meio bastante ineficaz de desobstrução dos tribunais, pois em lugar de criar o efeito de reunir a parcela homogênea das pretensões para uma decisão conjunta e uniforme, ele acaba por se converter em mais um processo que vem a se somar às diversas lides individuais já distribuídas, com pouca repercussão sobre a classe substituída que insistiu na condução de seus processos individuais. Não há, assim, qualquer ganho de eficiência. Essa distorção foi percebida por KAZUO WATANABE que, lamentando as cento e trinta mil ações buscando revisão de tarifas de telefonia no Estado de São Paulo,

ressarcimento pelo dano que lhe foi pessoalmente acusado, enquanto na ação coletiva o que se pretende é a reparação do dano causado ao interesse jurídico metaindividual. Não se trata de diversidade quantitativa, como poderia a princípio parecer, mas sim qualitativa, a inviabilizar por absoluto o reconhecimento de continência entre as duas demandas, a coletiva e a individual" (Manual do processo coletivo, cit., p. 255). Mais adiante, o autor admite a reunião dos processos coletivo e individuais em razão da conexão, o que não nos parece adequado. A conexão, em si, entre todas as situações individuais da classe é evidente: é justamente a coincidência dos aspectos homogêneos das pretensões individuais que justifica a ação civil coletiva e a sentença genérica que resolve as questões comuns. Mas ela não leva à reunião de processos, pois a solução do Código foi outra: em regra, devem os processos tramitar em paralelo sem interferirem um com o outro.

${ }^{115}$ Nesse sentido: ARAÚJO FILHO, Luiz Paulo da Silva. Ações coletivas: a tutela jurisdicional dos direitos individuais homogêneos, cit., cit., p. 155. 
processadas de forma concomitante a ação coletivas, concluía ser esta uma situação que "em virtude da inexistência de uma regra explícita, está provocando embaraços enormes à Justiça, com repetição absurda de demandas coletivas e também de pseudo-demandas individuais" ${ }^{\prime 16}$. Para sanar esse problema, o Projeto de Lei $n^{\circ} 5.139 / 09$, cujo objeto era a introdução de um novo Código de Processos Coletivos, previa em seu artigo 37 a suspensão automática das ações individuais.

Ocorre que mesmo diante da rejeição do Projeto de Lei pela CCJ da Câmara dos Deputados, em outubro de 2009, ao julgar o recurso especial $\mathrm{n}^{\circ} 1.110 .549 / \mathrm{RS}$, o Superior Tribunal de Justiça veio a manter decisão do Tribunal de Justiça do Rio Grande do Sul que havia determinado a suspensão compulsória de ações individuais que reivindicam diferenças de correção monetária sobre saldos de caderneta de poupança, em razão da existência de ação civil coletiva promovida pelo Ministério Público com o mesmo objeto. O voto que conduziu a maioria no âmbito da Segunda Seção, do Min. Sidnei BenetTi, valeu-se da suspensão automática de processos fundados em idêntica questão a ser julgada em recurso representativo de controvérsia (artigo 543-C, do Código de Processo Civil), e estendeu sua aplicação às ações civis coletivas, naquilo que chamou de "harmonização e atualização de interpretação". Quanto a isso, consideramos que a suspensão dos processos individuais cujos titulares não tenham optado pelo direito de exclusão da classe ("optout"), cujo mecanismo de funcionamento também deve receber aperfeiçoamentos na lei brasileira, é medida até mesmo necessária para que a ação civil coletiva obtenha a economia de recursos da Justiça e a uniformidade de julgamento que a justificam ${ }^{117}$.

Porém, ao decidir como decidiu, o Superior Tribunal de Justiça parece ter ultrapassado todos os limites válidos de interpretação do texto do artigo 104 da Lei $\mathrm{n}^{\circ}$ 8.078/90, que é muito claro em condicionar a suspensão a requerimento do autor individual, e cuja especialidade não permite afirmar sua derrogação pela Lei $n^{\circ} 11.872 / 08$, que introduziu o artigo 543-C no Código de Processo Civil. Ainda que tenha sido bem intencionado, o tribunal excedeu seus poderes de uniformização da interpretação da lei federal e decidiu de forma contrária ao texto legislativo expresso, o que não pode ser tido como algo positivo.

\footnotetext{
${ }^{116}$ WATANABE, Kazuo. Relação entre demanda coletiva e demandas individuais, cit.

${ }^{117}$ Em tom elogioso, FREDIE DIDIER Jr. e HERMES ZANETI Jr. afirmam que "o STJ deu um grande passo na racionalização do sistema de tutela dos direitos, dando-lhe mais coerência e eficiência. Percebe-se que mudanças legislativas, às vezes, são desnecessárias; a mudança do repertório teórico do aplicador é muito mais importante" (Curso de direito processual civil: processo coletivo, cit., v. 4, p. 194).
} 


\subsection{Da coisa julgada erga omnes e secundum eventum litis}

O Código de Defesa do Consumidor regulamentou também de maneira diferenciada o regime de extensão subjetiva da coisa julgada da sentença genérica coletiva, adotando para isso a conjugação de duas regras, que se encontram presentes na redação do artigo 103 , inciso III.

A primeira delas é a da eficácia erga omnes da coisa julgada, que abrange todas as vítimas e seus sucessores. Como veremos no último capítulo, essa regra define a coisa julgada coletiva não apenas na extensão subjetiva, como também em seu perfil objetivo: a situação concreta que se julga na sentença genérica é a das vítimas e sucessores, e não uma questão jurídica (a responsabilidade) tomada em abstrato. Há uma lide coletiva a respeito da qual se julga, e a eficácia erga omnes opera dentro desses limites. E quanto à extensão subjetiva da coisa julgada, propriamente dita, é um pressuposto indispensável de utilidade da sentença coletiva que ela irradie vínculos sobre as ações complementares a serem movidas pelos substituídos, que não foram partes do processo, sob a pena de se mostrar completamente desprovida de propósito ${ }^{118}$.

A segunda faceta da definição legal - e a mais polêmica - é a eficácia secundum eventum litis, que consiste no fato de que o julgado somente opera para beneficiar os terceiros ausentes (isto é, os titulares do interesse deduzido em juízo), não podendo prejudicá-los, a não ser que tenham optado por intervir no processo coletivo como litisconsortes. A coisa julgada secundum eventum litis é tradicionalmente criticada no contexto do processo individual, pois dificilmente se justifica que a pessoa que esteve presente em juízo para defender seus interesses não seja prejudicada por um julgamento desfavorável.

Entretanto, o que se verifica da análise do regime da coisa julgada para os direitos individuais homogêneos é que a imutabilidade da decisão não é verdadeiramente

\footnotetext{
${ }^{118}$ Nesse sentido, RODOLFO DE CAMARGO MANCUSO ressalta que "a própria extensão dos temas que aí afluem (meio ambiente, consumidores, patrimônio cultural, moralidade administrativa), faz com que a imutabilidade agregada tenha de se projetar em intensidade maior ou menos para fora do processo, como condição para se alcançar a faixa do universo coletivo correspondente ao interesse judicializado" (Jurisdição coletiva e coisa julgada: teoria geral das ações coletivas, cit., p. 121). Em outros termos, "não seria possível imaginar verdadeiro processo 'coletivo' sem que a coisa julgada fosse "coletiva'”. (LEONEL, Ricardo de Barros. Manual do processo coletivo, cit., p. 259).
} 
condicional, ao contrário do que o que se passa com os direitos difusos e coletivos, em que se admite a nova propositura da ação rejeitada com base em novas provas ${ }^{119}$.

Como anota o professor José IGNÁcio Botelho DE MESQuita, de fato, o regime de extensão subjetiva da coisa julgada no Código de Defesa do Consumidor não destoa significativamente dos princípios da coisa julgada no processo individual ${ }^{120}$, pelo menos para aqueles que aceitam a distinção que LIEBMAN traçou entre autoridade da coisa julgada e eficácia da sentença ${ }^{121}$. É habitual que a sentença, como ato de império estatal, possa irradiar efeitos sobre a situação jurídica de terceiros que não participaram do processo. A vedação a futuras discussões sobre a decisão, que a tornam imutável, é normalmente restrita as partes que se submeteram ao contraditório. Dessa forma, o regime de extensão subjetiva da coisa julgada do Código de Defesa do Consumidor se diferenciaria do sistema do Código de Processo Civil apenas por vincular os legitimados concorrentes que não foram partes ao resultado do processo. Segue daí, como vem a concluir ANTONIO GIDI, que a coisa julgada na realidade não é verdadeiramente secundum eventum litis $^{122}$, pois as

\footnotetext{
${ }^{119} \mathrm{~A}$ diferença no regime da coisa julgada sobre interesses difusos e coletivos, em comparação com aquela que tem por objeto os interesses individuais homogêneos, justificada por ARRUDA ALVIM pelo fato de que a convocação dos membros da classe para intervirem como litisconsortes (art. 94) seria suficiente para que todas as provas conhecidas fossem levadas à ação coletiva: "a diferença de redação entre os incs. I e II do art. 103 e o inc. III do mesmo art. 103 reside em que, nas duas primeiras hipóteses, admite-se que, se julgada improcedente por insuficiência de provas e em face de nova prova, pode haver repropositura da ação civil coletiva pela não-ocorrência de coisa julgada, o que não se passa com o caso do inc. III do art. 103. Isso é assim porque nas duas primeiras hipóteses não existe colaboração possível ou, ao menos, um "convite" para que os interessados, propriamente ditos, possam atuar." (Notas sobre a coisa julgada coletiva. Revista de Processo, São Paulo, n. 88, p. 35, out./dez. 1997).

${ }^{120}$ “Se improcedente a ação, a sentença será imutável e indiscutível apenas para as partes, como já decorre das disposições do Código de Processo Civil. Se a ação for julgada procedente, estará inteiramente satisfeito o fim das ações concorrentes, nada importando que a sentença torne indiscutível ou não; não haverá mais ação alguma, com o mesmo objeto, a ser proposta. Igualmente desnecessária é da regra do $§ 2^{\circ}$ do art. 103. A sentença de improcedência dessa ação coletiva contém a conclusão de que o réu não está obrigado a indenizar. Esta conclusão, por força do trânsito da sentença em julgado, tornar-se-á imutável e indiscutível perante as partes, mas não prejudicará terceiros. Logo, prejudicará as ações 'individuais' dos que foram partes no processo, mas não prejudicará as dos que dele não participaram. Tudo isto, porém, conforme já decorreria da aplicação do sistema do Código de Processo Civil.” (BOTELHO DE MESQUITA, José Ignácio. A coisa julgada no Código do Consumidor, cit., p. 38-39).

${ }^{121}$ Registre-se que a teoria de LIEBMAN, apesar de ter sido muito bem aceita no Brasil, não é unânime. As correntes substancialistas da coisa julgada, que ainda têm defensores na Itália, rejeitam a distinção entre efeitos da sentença e coisa julgada, bem como a própria limitação subjetiva da última.

122، Assim como na ação coletiva em defesa de direitos superindividuais, a coisa julgada coletiva se formará independentemente do resultado da demanda, seja a ação julgada procedente ou improcedente. A coisa julgada se forma pro et contra, e não secundum eventum litis. O que é secundum eventum litis é a extensão in utilibus da coisa julgada para a esfera individual das vítimas do evento." (GIDI, Antonio. Coisa julgada e litispendência em ações coletivas, cit., p. 140) No mesmo sentido, ARRUDA ALVIM afirma que "(...) no plano desta ação civil coletiva (hipótese do art. 103, III, do Código de Defesa do Consumidor), se opera sempre coisa julgada, seja caso de procedência, seja de improcedência, e mesmo que a ação tenha tido esse resultado de improcedência em face de insuficiência de prova. O que ocorrerá, se houver improcedência, é a não-qualificação da coisa julgada erga omnes, rigorosamente entendida, isto é, no seu sentido próprio e como tal existente no processo tradicional, qual seja, o de que abrangeria todas as pessoas da coletividade,
} 
partes do contraditório - autor coletivo e réu - ficarão vinculadas ao resultado do processo independentemente de seu resultado.

Sem que se tire a razão desses autores, ainda assim nos parece que o Código fez bem em regulamentar a matéria de maneira explícita, de modo a deixar clara a política de extensão da coisa julgada que se desejava então estabelecer. Isto porque a visão de LIEBMAN acerca da coisa julgada nas ações concorrentes, de fato muito preocupada em resguardar a posição jurídica do terceiro, não é unânime na doutrina ${ }^{123}$. E também porque, em se tratando de substituição processual, há grande divisão na doutrina sobre ser regra ou não a extensão da coisa julgada desfavorável ao substituído ${ }^{124}$.

Aspecto que recebeu algumas críticas por ocasião da sua edição do Código do Consumidor foi o relacionado à justiça, para com o réu, de não se estender a coisa julgada a terceiros em caso de improcedência da demanda coletiva, tornando imutável e indiscutível a conclusão do julgado que afastasse a responsabilidade genérica ${ }^{125}$. E de fato, há que se pontuar que o regime de extensão da coisa julgada a terceiros apenas para beneficiar da lei brasileira é singular. No direito comparado, a extensão subjetiva da coisa julgada tende a seguir dois critérios: o da opção expressa de cada indivíduo pela sua sujeição aos resultados da ação coletiva (opt-in), ou então o da vinculação obrigatória dos membros da classe aos resultados do processo, com opção para que os indivíduos, antes do julgamento, manifestem sua opção pela exclusão do grupo representado no processo (opt-

com situação individual subsumível àquela que tenha, ainda que em 'linguagem coletiva', retratada na ação civil coletiva" (Notas sobre a coisa julgada coletiva, cit., p. 37). FREDIE DIDIER Jr. e HEMES ZANETI Jr. abraçam o mesmo entendimento (Curso de direito processual civil: processo coletivo, cit., v. 4,p. 374).

${ }^{123}$ Posicionaram-se contrariamente ao entendimento de LIEBMAN nessa questão autores de expressão como BARBOSA MOREIRA, que manifestou o entendimento de que a coisa julgada deveria se estender a todos os legitimados concorrentes (Litisconsórcio unitário. Rio de Janeiro: Editor Borsói, 1972. p. 143), e ADA PELLEGRINI GRINOVER (Notas a "Ações concorrentes" e "Pluralidade de partes legítimas à impugnação de um único ato". In: LIEBMAN, Enrico Tullio. Eficácia e autoridade da sentença e outros escritos sobre a coisa julgada. Tradução de Alfredo Buzaid e Benvindo Aires, com notas de Ada Pellegrini Grinover. 4. ed. Rio de Janeiro: Forense, 2007. p. 229-239).

${ }^{124}$ Para um relato da polêmica, vide CRUZ E TUCCI, José Rogério. Limites subjetivos da eficácia da sentença e da coisa julgada civil. São Paulo: Ed. Revista dos Tribunais, 2006. p. 226-228, com o registro de que a doutrina majoritária defende a extensão da coisa julgada para o substituído. Além disso, cabe também registrar a tendência, decorrente da tradicional doutrina da substituição processual, de enxergar o substituído na condição de parte material sujeita aos efeitos do processo, conforme lembra o mesmo autor (CRUZ E TUCCI, José Rogério. Limites subjetivos da eficácia da sentença e da coisa julgada nas ações coletivas, In: __ . O advogado, a jurisprudência e outros temas de processo civil. São Paulo: Quartier Latin, 2010. p. 195-196).

${ }^{125}$ BOTELHO DE MESQUITA, José Ignácio. Na ação do consumidor, pode ser inútil a defesa do fornecedor. Revista do Advogado, São Paulo, n. 33, p. 80-81, dez. 1990. Também ALUÍSIO GONÇALVES DE CASTRO MENDES afirma que "o julgamento contrário à parte que efetuou a defesa não produzirá efeitos erga omnes, o que merece ser criticado, porque viola o princípio da isonomia. (...) O processo coletivo torna-se, assim, instrumento unilateral, na medida em que só encontra utilidade em defesa de uma das partes" (Ações coletivas no direito comparado e nacional, cit., p. 279). 
out). Nessas duas situações, aqueles que se sujeitarem aos resultados do processo, seja por terem manifestado expressamente esse desejo, seja por não terem exercido tempestivamente o direito de exclusão, ficarão vinculados à coisa julgada em qualquer hipótese, seja ela benéfica ou prejudicial.

Defendendo o regime da lei brasileira em relatório recente voltado à comparação dos diversos sistemas de extensão dos efeitos da sentença e da coisa julgada a terceiros, Ada Pellegrini Grinover manifesta que características da sociedade brasileira como "a falta de informação e de conscientização a respeito de seus direitos de grandes parcelas da população, a dificuldade de comunicação, a distância e a precariedade dos meios de transporte, a dificuldade de acesso à justiça, as barreiras para a contratação de um advogado" 126 tornam a regra da extensão dos efeitos apenas para beneficiar os indivíduos interessados a mais aderente a essas condições. Entretanto, parece pertinente a crítica de Aluísio GonçAlves de CASTRO MENDES, para quem esse regime relega a ação coletiva a um papel secundário e residual, quando ela deveria ser o referencial mais importante para a solução de um conflito de massa ${ }^{127}$. Por essa razão, o autor defende a adoção de uma coisa julgada vinculante para toda a classe, qualquer que seja o resultado do processo, assegurado o direito à exclusão por parte de cada indivíduo. Nesse mesmo sentido, MÁrcio Flávio MAFRA LEAL aponta, com certa ironia, que ao perceber que o processo coletivo também pode gerar prejuízos para a classe, a lei abriu mão do discurso em torno da necessidade de abolir a leitura tradicionalista da cláusula do devido processo legal ${ }^{128}$.

\footnotetext{
${ }^{126}$ GRINOVER, Ada Pellegrini. Novas tendências em matéria de ações coletivas nos países de civil law. Revista de Processo, São Paulo, n.157, p. 147-164, mar. 2008. No mesmo sentido, ZUFELATO, Camilo. Coisa julgada coletiva, cit., p. 434-443.

${ }^{127}$ Após citar diversos conflitos de massa levados à Justiça nas últimas duas décadas, em que o ajuizamento de ações coletivas não inibiu o processamento em paralelo de ações individuais, CASTRO MENDES conclui que "em praticamente todos os casos mencionados, foram centenas de milhares de processos individuais instaurados, sem que as ações coletivas tenham de fato cumprido seu papel. O correto equacionamento da questão da litispendência e da coisa julgada, com o estabelecimento de um efetivo sistema de exclusão, parece ser medida essencial para que a tutela coletiva alcance seus objetivos" (A coisa julgada e os processos coletivos no direito vigente e no projeto de nova lei da ação civil pública. In: GOZZOLI, Maria Clara; CIANCI, Mirna; CALMON, Petrônio; QUARTIERI, Rita. Em defesa de um novo sistema de processos coletivos: estudos em homenagem a Ada Pelegrini Grinover. São Paulo: Saraiva, 2010. p. 71); no mesmo sentido, MENDES, Aluisio Gonçalves de Castro. Ações coletivas no direito comparado e nacional, cit., p. 276-278.

128،Esse argumento, da doutrina brasileira como um todo, do ponto de vista teórico é paradoxal. Por um lado, para se permitir a propositura da ação coletiva, faz-se um libelo contra o processo individual, com argumentos do movimento de acesso à Justiça e pregando-se a necessidade de se superarem as barreiras tradicionais impostas pela cláusula do devido processo legal, com o princípio do contraditório incluído. Quando se percebe que o pedido na ação coletiva pode ser improcedente, recorre-se aos mesmos argumentos que no primeiro momento rechaçaram: os princípios do processo civil clássico (contraditório, ampla defesa, etc.). Ora, ou se permite a extensão da coisa julgada, em função da adequada representatividade, ou se procuram outros argumentos para justificar o regime secundum eventum litis, pois na forma em que está a doutrina, há uma evidente antinomia teórica" (LEAL, Márcio Flávio Mafra. Ações coletivas: história, teoria e prática, cit., p. 210).
} 
A crítica contra a extensão secundum eventum litis da coisa julgada parece ter encontrado ressonância nos projetos de reforma do processo coletivo. Nesse sentido, o Projeto de Lei $n^{\circ} 5.139 / 09$, alterava a orientação da lei atual para permitir a coisa julgada pro et contra, ou seja, a extensão da decisão favorável a toda a classe substituída quando a demanda coletiva tivesse por causa de pedir matéria de direito (art. $34, \S 1^{\circ}$ ); sendo possível o prosseguimento das ações individuais se o fundamento da improcedência na ação

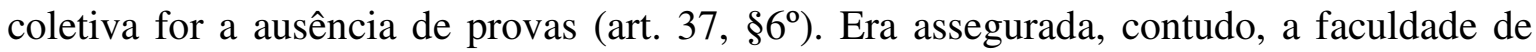
exclusão dos indivíduos interessados até a publicação da sentença, pelo que se pode afirmar que o Código projetado substituía o atual regime de coisa julgada secundum eventum litis pela técnica do opt-out. O regime projetado tinha a vantagem de assegurar ao processo coletivo o papel de referencial prioritário na resolução do conflito de massa, atentando para o fato, sublinhado por Rodolfo DE CAMARgo Mancuso, de que "tergiversar sobre o trato processual coletivo aderente aos megaconflitos implica o risco de vê-los recrudescer, acarretando, ainda mais, a proliferação desenfreada de demandas plúrimas e replicadas" $" 129$.

\subsection{Transição}

Nas linhas que antecederam o presente item, buscamos fazer uma breve exposição das mudanças sociais que originaram os conflitos de massa e geraram o movimento por formas coletivas de tutela de direitos, indicamos os objetivos gerais que o chamado processo coletivo visa a atender e, por fim, analisamos o regime jurídico da ação civil coletiva brasileira, regulamentada em poucos artigos da Lei $\mathrm{n}^{\circ}$ 8.078/90, o Código de Defesa do Consumidor. Encerramos esta última parte do capítulo com referências ao regime da coisa julgada que recai sobre a sentença genérica coletiva (art. 95), o objeto do presente trabalho, que a lei definiu como erga omnes e secundum eventum litis, com a dupla finalidade de assegurar a sua extensão a terceiros interessados na questão discutida na fase coletiva do processo e de evitar que suas pretensões individuais pudessem ser sacrificadas em um processo no qual não tiveram a possibilidade de intervir. Mas destacamos também aquela que nos parece ser a principal característica do procedimento especial: a reorganização da atividade cognitiva que se processa pela reunião das pretensões comuns a

\footnotetext{
${ }^{129}$ MANCUSO, Rodolfo de Camargo. Acesso à justiça: condicionantes legítimas e ilegítimas. São Paulo: Ed. Revista dos Tribunais, 2011.p. 414.
} 
toda uma classe que é representada no processo coletivo, com a simultânea cisão na estrutura básica de cada interesse individual, de modo a que o processo coletivo se limite à análise das questões comuns à classe e as questões individuais sejam posteriormente analisadas em processos complementares, movidos por cada um de seus membros.

Essa reorganização da atividade cognitiva, que é a nota distintiva da ação civil coletiva brasileira, irradia um especial significado para a coisa julgada que se forma sobre a sentença genérica. Por meio desse mecanismo, a importância do tradicional instituto passa a residir, mais do que em proporcionar a estabilidade de uma sentença de mérito, em uma nova função de conexão estrutural entre dois processos, coletivo e complementar, sem os quais não se integra a tutela jurídica coletiva. A chamada coisa julgada "erga omnes" de que trata o artigo 103, inciso III, do Código de Defesa do Consumidor, é o elemento de ligação estrutural entre a sentença genérica coletiva e os processos complementares, responsável pela definição do espaço de cognição possível e reservado a cada um deles. Assim, é ela que determina até que ponto se faz possível o julgamento concentrado de questões na fase coletiva ("fixação de responsabilidade"), bem como quais são os vínculos e preclusões que devem ser observados nas ações complementares ("coisa julgada"). Para além da relevância dessas implicações práticas, as observações feitas até este ponto já nos permitem registrar indagações acerca de particularidades nos aspectos objetivos da coisa julgada (seu conteúdo e limites) que, ao contrário do que se passa com a extensão subjetiva, não foram objeto de regulamentação pela lei. De fato, como foi registrado por REMO CAPONI, "o ordenamento conforma e dimensiona a coisa julgada"130, de modo que a resposta a essas perguntas inevitavelmente dependerá de algum trabalho de construção doutrinária a partir de dois referenciais: a disciplina da ação coletiva constante do direito positivo, que gera a força conformadora e dimensionadora de que fala CAPONI, conjugada com aquela da coisa julgada no Código de Processo Civil.

Essa opção de método visa a assegurar uma interpretação coerente e unitária do direito processual, evitando que o estudo isolado das regras especiais do subsistema de tutela coletiva conduza à fragmentação do ambiente em que este está inserido, que é o

\footnotetext{
${ }^{130}$ CAPONI, Remo. Il giudicato civile dimensionato. Rivista trimestrale de diritto e procedura civile, anno 63, n. 3, p. 941-954, set. 2009. O professor da Universidade de Florença, refletindo sobre a azioni colletiva risarcitoria do art. 140-bis do Código do Consumo italiano, defende que esse dimensionamento torna a coisa julgada variável e determinável em concreto, tese que examinaremos no último capítulo desta dissertação.
} 
próprio sistema processual ${ }^{131}$. Para lidar com a crescente complexidade advinda de leis especiais, assim, é necessário identificar os eixos de racionalidade comuns a todas as expressões do direito processual, sempre na esperança de que essa tarefa consiga proporcionar um grau mínimo de segurança quanto ao conteúdo da lei e a igualdade de tratamento aos cidadãos, sem os quais o exercício da jurisdição se tornaria política e socialmente inaceitável. WALTER PIVA RODRIGUES, a propósito dessa importante questão de método, adverte para o fato de que "a moderna visão do processo desce mais a fundo no exame comparativo e descobre a unidade processual pelo aspecto teleológico. Assim, as formas peculiares do processo convergem, todas, para a mesma finalidade, que é a de impor, no caso concreto, uma ordem correspondente à ordem estabelecida na lei"132 ${ }^{\text {. Por }}$ isso, dedicaremos o próximo capítulo à teoria da coisa julgada civil, identificando as premissas que tradicionalmente determinam o instituto, como preparação para a análise particular da coisa julgada, conformada e dimensionada pela peculiar sentença genérica coletiva.

\footnotetext{
${ }^{131}$ Em estudo dedicado à crise da lei processual em tempos recentes, MICHELLE TARUFFO afirma que uma das causas da crise da justiça deriva da crescente complexidade e confusão da legislação especial. Diz ele: "Un primo fenomeno deriva dalla scarsa possibilità diassecurarerl'ordine e l'unità della legge processuale. Prevale invece la tendenza oposta alla frammentazione e, di conseguenza, alla mancanza di ordine sistematico (...) l'unitarietà del sistema processuele si rompe tutte le volte in cui il legislatore intende sotrarre determinati soggetti o gruppi di soggeti al funzonamento inefficiente della legge processuale generale. Normalmente ciò comporta un miglioramento della protezione dei diritti di questi soggetti, però provoca effetti negativi sul sistema inteso nel suo complesso". (Razionalità e crisi della legge processuale, In: _. Sui confini: scritti sulla giustizia civile. Bologna: Il Mulino, 2002. p. 55-56).

${ }^{132}$ PIVA RODRIGUES, Walter. Coisa julgada tributária. São Paulo: Quartier Latin, 2008. p. 14.
} 


\section{A COISA JULGADA CIVIL}

\subsection{Condicionantes político-institucionais para a moderna teoria da coisa julgada: a integração da jurisdição ao Estado e o surgimento da ciência do processo como ramo do direito público}

Antes de examinarmos a teoria da coisa julgada e sua disciplina positiva no Código de Processo Civil de 1973, e diante das profundas divisões que existem na doutrina a respeito do tratamento dessa matéria, sentimos a necessidade de introduzirmos este segundo capítulo com a exposição de alguns fundamentos relacionados à posição institucional da jurisdição no moderno Estado social de direito e seus reflexos sobre a teoria geral do processo. Esses fundamentos, que estão à base do processo civil atual, devem condicionar a teoria da coisa julgada ${ }^{133}$, e por isso os tomaremos como ponto de apoio para justificar nosso posicionamento teórico nas questões em que a doutrina processual não alcançou ainda entendimento convergente.

Como se sabe, o direito processual - considerado como disciplina autônoma surgiu apenas na modernidade, especificamente após as revoluções liberais que sucederam os regimes absolutistas, estabelecendo uma técnica de limitação do poder baseada na divisão das funções estatais ${ }^{134}$, que foram atribuídas a Poderes independentes entre si. Essa

\footnotetext{
${ }^{133}$ Como anota EDUARDO COUTURE, a coisa julgada não é um fim em si mesmo. Ela é um instrumento que o Estado adota para realizar determinadas finalidades. "Entre la autoridad de cosa juzgada y la efectiva vigencia del derecho hay una relación di medio a fin. La cosa juzgada se concibe sólo como medio de despejar la incertidumbre del derecho y como forma de hacerlo coactivo en los casos de resistencia $u$ omisión de su cumplimento (...) la cosa juzgada por si misma no si justifica; su singular energia vale como medio y no como fin. El fin no es por supuesto, la inmutabilidad. Lo es la justicia, la paz, el orden, la seguridad, es decir, los valores los cuales el derecho accede y sirve (Fundamentos del derecho procesal civil. 4. ed. Montevideo-Buenos Aires: Editorial B de F, 2007. p. 33). E nesse sentido, anota ADROALDO FURTADO FABRÍCIO que as divergências doutrinárias em torno do conceito de coisa julgada remontam à justificação política do instituto, mais do que a divergências estritamente jurídicas: "A justificação do instituto continua a assentar, como ao tempo dos romanos, em bases antes políticas e sociológicas do que propriamente jurídicas. Não é por outro motivo que, ainda hoje, entre as proposições numerosas e variadas tendentes a justificar no plano jurídico o instituto, nenhuma logrou pacificar em torno de si a doutrina, ou sequer reunir soma expressiva de opiniões convergentes. Nenhuma delas dispensa, outrossim, o socorro do embasamento sociológico, fracassando as que dele quiseram prescindir" (Ação declaratória incidental. 4. ed. São Paulo: Saraiva, 2009. p. 56).

${ }^{134}$ A classificação das funções públicas não foi uma invenção do período moderno. ARISTÓTELES, em sua investigação sobre as formas ideais de governo, já havia identificado três poderes existentes em todo governo: o deliberativo, o executivo e o judiciário. Segundo de lê n'A Política, "Em todo governo existem três poderes essenciais, cada um dos quais o legislador prudente deve acomodar da maneira mais conveniente. Quando estas três partes estão bem acomodadas, necessariamente o governo vai bem, e é das diferenças entre estas partes que provêm as suas dificuldades. O primeiro destes três poderes é o que
} 
técnica trouxe a jurisdição (até então um assunto privado que interessava somente às partes em litígio) para dentro do aparelho do Estado, vinculando-a ao poder político e subordinando-a a uma nova função de fazer aplicar as leis por ele previamente instituídas, em caráter de monopólio. É a essa apropriação da jurisdição pelo Estado que nos referimos, quando falamos em sua publicização, e conseqüente ganho de autonomia frente ao direito privado.

Há consenso entre os processualistas em situar o surgimento de sua ciência na segunda metade do século XIX, ora indicando-se como seu marco inicial a sistematização pioneira da relação jurídico-processual contida na obra de OSKAR VON BULOW, que destacou o caráter público que a jurisdição então assumia ${ }^{135}$, ora se localizando essa origem um pouco alguns anos antes, na polêmica em torno ao conceito de moderno de “ação" que opôs os romanistas WINDSHEID e MUTHER ${ }^{136}$, em que essa mesma discussão era introduzida, embora de maneira mais sugerida do que explícita. Mais importante, porém, do que atribuir a qualquer de seus autores a paternidade do processo moderno, é compreender que essas obras são retratos de seu tempo, e refletiam as influências que as alterações políticas então vivenciadas irradiavam sobre a teoria do direito. $\mathrm{E}$ assim é que o direito processual, com as feições pelas quais o conhecemos e o estudamos - um ramo do direito público, autônomo em relação ao direito dito material, mas funcionalizado à tutela dos direitos que este último reconhece - somente foi concebido nesse ponto relativamente tardio da história.

Sabemos que essa constatação, feita de forma isolada, é de pouco interesse, quer para o estudo da coisa julgada, quer para os estudos de direito processual. No entanto, fazemos aqui essa digressão por acreditarmos que as causas políticas e sociais que estiveram associadas ao surgimento da ciência do processo não devem ser subestimadas

delibera sobre os negócios do Estado. O segundo compreende todas as magistraturas ou poderes constituídos, isto é, aqueles de que o Estado precisa para agir, suas atribuições e a maneira de satisfazê-las. O terceiro abrange os cargos de jurisdição" (ARISTÓTELES. A política. 3. ed. São Paulo: Martins Fontes, 2006. p. 127). A contribuição da teoria do Barão de MONTESQUIEU consistiu na idéia de isolar institucionalmente essas dimensões do poder público, como forma de prevenir o arbítrio dos governantes.

135،Desde que los derechos y las obligaciones procesales se dan entre los funcionarios del Estado y los ciudadanos, desde que se trata en el proceso de la función de los oficiales públicos y desde que, también, a las partes se les toma en cuenta únicamente en el aspecto de su vinculación y cooperación con la actividad judicial, esa relación pertenece, con toda evidencia, al derecho público y el proceso resulta, por lo tanto, una relación jurídica pública" (BULOW, Oskar. La teoría de las excepciones procesales y los presupuestos procesales. Trad. española. Buenos Aires: Europa-America, 1968. p. 1-2). BULOW registra ainda que a influência medieval limitou o processo ao estudo do procedimento, ao passo em que identifica na (desordenada) teoria das exceções dilatórias o embrião do estudo da relação jurídica processual como ramo autônomo do direito.

${ }^{136}$ WINDSCHEID, Bernhard; MUTHER, Theodor. Polemica in torno all'actio. Trad. de Giovanni Pugliese e Ernesto Heinitz. Firenze: Sansoni, 1954. 
como fontes de elementos doutrinários que nos permitirão assumir posições firmes diante das diversas polêmicas que envolvem o instituto da coisa julgada, de forma contextualizada às finalidades do processo e da jurisdição no moderno Estado de Direito.

A razão pela qual a jurisdição foi trazida ao direito público insere-se no contexto da centralização do poder político que caracterizou a formação do Estado moderno. Atualmente, estamos acostumados a identificar o direito com um corpo único e ordenado de normas postas por um ato de vontade do Estado, o direito positivo. Essa concepção é, contudo, relativamente nova. O direito europeu continental do período medieval, em razão do caráter pluralista e fragmentário de sua sociedade, em que o poder político era disperso, tinha sua origem em uma diversidade de fontes não-estatais: um direito comum tradicional, de raiz romana, mas adaptado pela leitura que dele fizeram os povos germânicos; os estatutos das diversas corporações de ofício; o direito canônico da Igreja Católica Romana; o costume; a equidade; e, acompanhando o movimento de ascensão do pensamento racionalista do Iluminismo, o direito natural vinha desde então ocupando um espaço de crescente importância até que, séculos depois, seus desenvolvimentos filosóficos e políticos viessem fornecer as bases para as revoluções liberais e no constitucionalismo moderno. Esses diversos ordenamentos de regras se interpenetravam, sem que entre eles houvesse relação de hierarquia ou coordenação ${ }^{137}$.

E embora não houvesse ainda nessa época um direito processual, no direito medieval existia a prática da jurisdição civil, em que os conflitos surgidos na vida social eram levados ao exame de um terceiro imparcial, investido pelas partes, em razão de seu prestígio perante a comunidade, nos poderes de analisar os casos e decidir a quem cabia a razão. Mas as características da atividade jurisdicional, nesse período, eram profundamente diferentes das que individualizam o processo civil moderno. Sem qualquer ligação com o poder político, a jurisdição era exercida como uma exigência prática da vida social. Nesse sentido, ela se configurava como uma extensão do direito privado, e os diversos institutos relacionados ao iudicium eram por ele assimilados: a ação, a prova, e a res iudicata, eram todos vistos com expressões do direito civil. A função do juiz era honorífica e decorria de seu prestígio perante a comunidade, ou seja, não havia uma magistratura profissional, e os

\footnotetext{
137، A sociedade medieval era uma sociedade pluralista, posto ser constituída por uma pluralidade de agrupamentos sociais cada um dos quais dispondo de um ordenamento jurídico próprio: o direito aí se apresentava como um fenômeno social, produzido não pelo Estado, mas pela sociedade civil. (...) O Estado primitivo em geral não se preocupa em produzir normas jurídicas, mas deixa sua formação a cargo do desenvolvimento da sociedade, e eventualmente aquele que deve dirimir as controvérsias, o juiz, tem a incumbência de fixar, de quando em quando, a regra a ser aplicada". (BOBBIO, Norberto. O positivismo jurídico: lições de filosofia do direito. São Paulo: Ícone, 2006. p. 27).
} 
juízes não eram investidos em sua posição pelos governantes. Prevalecia, no julgamento, um raciocínio do tipo problemático, em que as diversas regras de conduta presentes de forma fragmentada eram organizadas pelo julgador, de maneira mais pragmática do que sistemática, de modo a apoiar a solução construída para o caso concreto: tratava-se da tópica, ou ars inveniendi ${ }^{138}$, como método de decisão.

Quando se iniciou a formação dos primeiros Estados, com a organização e unificação do poder político pelas monarquias absolutistas, o príncipe chamou para si o monopólio da produção e da aplicação do direito. A jurisdição - retomando, ao menos nesse aspecto, as feições do período extra ordinem do direito romano ${ }^{139}$ - deixou de ser assunto privado e passou a se associar à autoridade do Estado, deixando a órbita da livre disponibilidade das partes em litígio ${ }^{140}$. Nesse contexto foram editadas as primeiras leis e Códigos de processo, que vieram a se sobrepor às formas do costume ${ }^{141}$. E finalmente, os escopos da jurisdição deixaram de se limitar à resolução do litígio, passando a incluir finalidades do próprio Estado, dentre as quais se destacava a de assegurar a imperatividade de sua lei. De fato, o poder de julgar era instrumento imprescindível à consolidação do monopólio da legislação e da própria centralização do poder político. Foi assim que o juiz,

\footnotetext{
${ }^{138}$ Para uma descrição do pensamento tópico, confira-se a obra de THEODOR VIEHWEG (Tópica $e$ jurisprudência: uma contribuição à investigação dos fundamentos jurídico-científicos. Porto Alegre: Sérgio Antonio Fabris, 2008), e para a devida contextualização com as instituições medievais é de utilidade a leitura do ensaio Do juízo ao processo, de NICOLA PICARDI (In: Jurisdição e processo, cit., p. 33 e ss.). O tema da contraposição entre os critérios de decisão no direito comum medieval e na modernidade é aprofundado no item 2.1.1, abaixo.

${ }^{139} \mathrm{E}$ é nesse sentido que a doutrina processual associou o surgimento do processo civil moderno às instituições romanas, propagando a idéia de que a humanidade viveu um período de obscurecimento representado pelo medievo e o direito comum-germânico, recuperado pelo Iluminismo e pela modernidade. É a idéia que se encontra, p. ex., em escritos de GIUSEPPE CHIOVENDA como Romanesimo e germanesimo nel processo civile (SAGGI di diritto processuale civile. Milano: Giuffrè, 1993, v. 1, p. 181225), L'idea romana nel processo civile moderno (In: SAGGI di diritto processuale civile. Milano: Giuffrè, 1993, v. 3, p. 77-94) ou Cosa giudicata e preclusione (SAGGI di diritto processuale civile, cit., v. 3, p. 231286). Entretanto, estudos posteriores de história do direito evidenciaram que a associação da jurisdição à autoridade estatal é apenas um ponto ocasional de contato entre o processo civil moderno e um período específico do direito romano, na medida em que aquele consiste muito mais no resultado da evolução política da sociedade na modernidade do que na intencional recuperação de uma herança tradicional romana. Nesse sentido, PICARDI, Nicola. Do juízo ao processo, cit., p. 34.

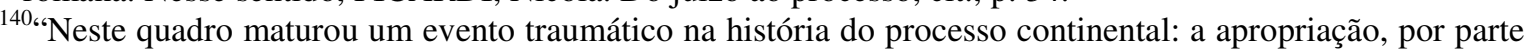
do príncipe, do ordo iudiciarius. Até a Idade Moderna o processo era considerado manifestação de uma razão prática e social, que se realizava no tempo com a colaboração da praxe e da doutrina. (...) Com a formação dos Estados modernos, mesmo com notáveis resistências, foi-se, ao contrário, afirmando o oposto princípio da estatalidade do processo: o soberano reivindicou o monopólio da legislação em matéria processual" (PICARDI, Nicola. Do juízo ao processo, cit., p. 61).

${ }^{141}$ Desse período datam a Prozess Gerichtsordnung, de 1622 e a Ordonnance civile touchant la reforme de la justice, o "Code Louis" de 1667, primeiros códigos saxão e francês (PICARDI, Nicola. Do juízo ao processo, cit., p. 61). Portugal conhece as primeiras leis gerais em 1211, mas a primeira sistematização de direito processual somente é concluída em 1446 pelo Livro $3^{\circ}$ das Ordenações Afonsinas (CRUZ E TUCCI, José Rogério; AZEVEDO, Luiz Carlos. Lições de história do processo civil lusitano. São Paulo: Ed. Revista dos Tribunais; Coimbra: Coimbra Ed., 2009. p. 32-33).
} 
em um primeiro momento, passou a ser visto como um funcionário do rei, encarregado de aplicar a lei por ele ditada. E como a partir dali havia uma única lei a se observar no julgamento, o método de raciocínio tópico-dialético cedeu espaço, progressivamente, ao método sistemático-interpretativo, que já desfrutava de grande prestígio em outros campos pela difusão da filosofia racionalista. A conseqüência que resulta de todos esses fatores é que a formação lógica da decisão perde importância como fator de legitimação da decisão, na medida em que a autoridade do Estado assume esse papel.

O caráter público do processo, em nossos dias, está intimamente associado ao constitucionalismo, que surgiu em uma segunda fase da modernidade, como reação liberal ao poder absoluto do Antigo Regime. Passava então o poder político a ser exercido em nome do povo, e seus representantes, eleitos por sufrágio, se tornariam responsáveis pela elaboração de uma lei fundada em critérios racionais e que refletisse a vontade geral. $\mathrm{O}$ juiz deixou de ser funcionário do rei e passou a gozar de independência frente ao governo, um instrumento das primeiras Cartas liberais orientado à limitação do poder. No entanto, ele se tornou vinculado à aplicação imparcial da lei, o que lhe assegurou o isolamento do sistema político e constituiu a fonte de sua autoridade. A magistratura, nesses termos, passou constituir uma burocracia, no sentido que MAX WEBER atribui a essa palavra no contexto da sociedade organizada em uma ordem de dominação do tipo racional-legal: agentes públicos profissionais e isolados do poder político, com competências e campos de ação delimitados apenas pela lei, que exercem assim uma autoridade do tipo institucional $^{142}$. A legalidade, portanto, é pressuposto da independência dos juízes na sociedade moderna ${ }^{143}$.

\footnotetext{
142، As categorias fundamentais da dominação racional são, portanto: 1 . um exercício, contínuo, vinculado a determinadas regras, de funções oficiais, dentro de 2. Determinada competência, o que significa: $a$ ) um âmbito objetivamente limitado, em virtude da distribuição de serviços, de serviços obrigatórios, $b$ ) com atribuição dos poderes de mando eventualmente requeridos e $c$ ) limitação fixa dos meios coercivos eventualmente admissíveis e das condições de sua aplicação. A um exercício organizado desta forma denominamos 'autoridade institucional" (Economia e sociedade: fundamentos da sociologia compreensiva. 4. ed. Brasília: Ed. Universidade de Brasília, 2004. v. 1, p. 141 e ss). WEBER distingue três tipos ideais de dominação legítima: a carismática, baseada nas características pessoais do soberano; a tradicional, baseada no respeito a tradições e estamentos consolidados na sociedade; e a racional-legal, típica da modernidade, baseada dos critérios impessoais estabelecido por leis genericamente aplicáveis. A finalidade dessa classificação é analítica, de modo que na realidade elas tendem a se apresentar de maneira entrelaçada em cada situação concreta.

${ }^{143}$ Nesse sentido é que CELSO FERNANDES CAMPILONGO, remetendo a BOAVENTURA DE SOUZA SANTOS, afirma que "a complexidade da politização do judiciário reside num paradoxo: 'o poder político dos tribunais assenta no caráter apolítico do seu exercício. Ou seja, um poder globalmente político tem de ser exercido apoliticamente em cada caso concreto", (Política, sistema jurídico e decisão judicial, cit., p. 108). E também segundo ARRUDA ALVIM, o princípio da legalidade, a profissionalização e o isolamento da magistratura são fenômenos indissoluvelmente ligados: "foi muito longa a caminhada do homem para conseguir um juiz que viesse aplicar imparcialmente a lei. Para que se conseguisse a realização da Justiça
} 
No entanto, a independência da magistratura, imprescindível ao desempenho de seu papel político no arranjo institucional de freios e contrapesos, foi durante muito tempo frustrada por uma série de medidas que submeteram o Poder Judiciário ao Executivo, provavelmente em razão da desconfiança com os juízes, que era declarada à época da Revolução Francesa ${ }^{144}$ e, ainda que enfraquecida, persiste até os dias atuais ${ }^{145}$. Na Europa somente veio a surgir uma magistratura dotada de garantias necessárias à sua independência política na segunda metade do século XX, quando os excessos das administrações fascista e nazista, bem como o seu trágico desfecho, despertaram a atenção do mundo para os perigos do autoritarismo.

A partir daí, a jurisdição e sua função política de limitação aos demais poderes passaram a ser vistos sob o prisma de uma garantia fundamental do cidadão. É emblemático que o direito ao processo e julgamento por juízes independentes e imparciais tenha sido inscrita na própria Declaração dos Direitos do Homem de $1948^{146}$, aprovada pela Assembléia Geral da Organização das Nações Unidas, como a sinalizar que a ausência

de forma justa, entendendo-se, neste passo, por justa, a fiel observância das leis, necessitou-se proteger o homem que a distribuía. Ainda, foi necessário especializar, no quadro das funções estatais, a função por ele exercida, com o que, impedindo-se a injunção dos outros poderes, ou mesmo de indivíduos poderosos, sobre o Judiciário, defendia-se a pessoa do juiz, como imparcial e justo aplicador da lei, não em favor do homem juiz, porém em benefício de sua função e, pois, da sociedade. A generalidade das Constituições ocidentais, expressões de nosso sistema comum de vida, consagra garantias de ordem pessoal e funcional que asseguram a liberdade do juiz: são as chamadas garantias fundamentais da magistratura" (ALVIM NETTO, José Manoel Arruda. Manual de direito processual civil. 14. ed. São Paulo: Ed. Revista dos Tribunais, 2011. p. 190-191).

${ }^{144}$ Conforme noticia JUAN MONTERO AROCA, "aunque tantas veces se haya sostenido lo contrario, em la concepción ideológica base de la Revolución Francesa la división de poderes no supuso um verdadeiro Poder Judicial, sino que los revolucionarios, partiendo de Montesquieu, sentían uma gran desconfianza frente a los tribunales (frente a los parlements). (...) El caso fue, sin embargo, que esta construción del barón de la Bréde no resistió al trasladarse al plano de la realidad (...)" (MONTERO AROCA, Juan. El derecho procesal en el siglo $X X$, cit., p. 45).

${ }^{145}$ A desconfiança do Poder Executivo frente ao Judiciário, no caso brasileiro, é retratada por BOTELHO DE MESQUITA nos artigos "A crise do judiciário e o processo" (cit., v. 1, p. 255-262) e "As novas tendências do direito processual: contribuições para seu reexame" (In: Teses, estudos e pareceres de processo civil: direito de ação - partes e terceiros - processo e política. São Paulo: Ed. Revista dos Tribunais, 2005. v. 1, p. 263-307). Neles se destaca a suspensão das garantias de estabilidade e vitaliciedade da magistratura instituída pelo Ato Institucional $\mathrm{n}^{\circ} 1$, de 1964, que perdurou por treze anos até a emenda Constitucional $\mathrm{n}^{\circ} 7$ de 1977; que, de seu turno, introduziu a representação para interpretação de lei ou ato normativo e a avocação de quais quer processos pelo Supremo Tribunal Federal, em exceção ao princípio do juiz natural. Afastados esses instrumentos pela Constituição de 1988, “dessa longa noite, sai o Poder Judiciário depauperado, moralmente abatido, arruinado economicamente, vendo comprometida assim sua eficiência, como a sua imagem perante a grande massa dos seus jurisdicionados, a cujos olhos se apresentava como um Poder omisso, inoperante e inacessível." (cit., p. 259). Medidas normativas muito mais recentes, como a proibição de liminares contra o Poder Público, a limitação dos efeitos da coisa julgada na ação civil pública refletiriam a mesma desconfiança já no regime democrático. Ou seja, a mesma situação de restrição à independência do Judiciário conhecida pelo Europa no pré-Guerra foi vivenciada em nosso país em tempos recentes, com influências que ainda se fazem sentir.

${ }^{146}$ Consta do Artigo X do documento: "Toda pessoa tem direito, em plena igualdade, a uma audiência justa e pública por parte de um tribunal independente e imparcial, para decidir de seus direitos e deveres ou do fundamento de qualquer acusação criminal contra ele". 
de uma magistratura verdadeiramente independente contribuíra de forma decisiva para os excessos autoritários que conduziram o mundo à II Grande Guerra ${ }^{147}$. Uma nova fase do publicismo no processo civil foi assim inaugurada em tempos mais recentes, pelo movimento de constitucionalização do processo, quando as garantias fundamentais do processo justo foram levadas às Constituições da segunda metade do século passado, consolidando o processo como instrumento ético e essencial aos governos democráticos. Esse movimento chegou ao nosso país de forma tardia, mas intensa, com a Constituição de 1988, que estabeleceu um amplo rol de garantias processuais, por ela diretamente tuteladas.

\subsubsection{As relações entre o juiz e a lei: a dualidade do ordenamento jurídico}

O passo seguinte em nossa aproximação do conceito de coisa julgada, na perspectiva dos condicionamentos externos que lhe são conferidos pelos atributos da função jurisdicional no Estado de direito social, consiste em estabelecer quais as relações entre o juiz e a lei no plano do processo jurisdicional, desde que no plano político - como vimos - a vinculação à legalidade se constituiu como fundamento da independência da magistratura.

A esse respeito, o reconhecimento da autonomia jurídica do processo foi seguido pelo que veio a ser conhecido como a teoria dualista do ordenamento jurídico, que se caracteriza por considerar em planos distintos o direito material e o direito processual, e por enxergar a jurisdição como uma função estatal destinada a aplicar o direito material preexistente aos casos concretos ${ }^{148}$. Essa concepção pressupõe uma função essencialmente

\footnotetext{
147،Foi em resposta aos trágicos resultados a que essas configurações da relação entre o juiz e a lei conduziram os povos submetidos ao flagelo do nazi-fascismo, que a Declaração Universal dos Direitos do Homem, inaugurando o após-guerra, se defrontou com a necessidade de reafirmar novamente a independência do juiz como condição do respeito aos direitos fundamentais" (BOTELHO DE MESQUITA, José Ignácio. As novas tendências do direito processual: contribuições para seu reexame, cit., p. 275).

${ }^{148}$ CÂNDIDO RANGEL DINAMARCO chama a atenção para a importância da dualidade do ordenamento para a dogmática do processo civil, dizendo que se trata de “(...) questão metodológica que se situa à cabeceira da teoria do processo; renunciar à tomada de consciência dessa questão significaria caminhas às escuras entre um emaranhado de institutos cuja disciplina harmoniosa depende de um preciso e decidido posicionamento a respeito de um denominador comum, de um elemento coordenador. Essa tomada de posição deve estar conscientemente presente na solução de significativos problemas angulares da ciência do processo, sendo esse o único modo de evitar graves contrastes lógicos que certamente comprometeriam qualquer doutrina científica como tal" (Direito e processo. In: moderno. 6. ed. São Paulo: Malheiros Ed., 2010. v. 1, p. 93). . Fundamentos do processo civil
} 
declarativa na função jurisdicional ${ }^{149}$, bem como uma diferença entre a incidência do direito, em abstrato, e sua aplicação pelos tribunais em concreto. Como veremos adiante, essa construção - que subordina a jurisdição à concretização do direito objetivo por meio de um comando concreto - é de grande importância para a determinação do conteúdo da demanda a ser deduzida em juízo e, portanto, para a determinação do conteúdo da coisa julgada ${ }^{150}$.

Mas a teoria dualista não é aceita de forma pacífica, e foi objeto de importantes contestações no século passado. Formou-se assim uma corrente de pensamento oposta, cujos integrantes convergem para uma concepção unitária do ordenamento. Em síntese, os defensores dessa doutrina, como SALVATORE SATTA, sustentam a teoria de que a lei é uma construção abstrata incapaz de regulamentar a conduta humana, de modo que o direito somente se realiza em concreto pela decisão judicial ${ }^{151}$. Concordando com essa premissa, FRANCESCO CARNELUTTI sustenta que a finalidade do processo não é a aplicação declarativa do direito preexistente, mas sim a composição da lide. E em tempos recentes MAURo CAPPELletti aderiu com entusiasmo a essas críticas, em seu estudo sobre os espaços de criação jurisprudencial do direito ${ }^{152}$. As conseqüências da adoção dessa segunda teoria, a propósito do tema deste trabalho, é que uma vez rompidos os vínculos de subordinação entre a jurisdição e a lei preexistente, permite-se uma liberdade de conteúdo muito maior no objeto do processo ${ }^{153}$, e diversas matérias de cunho abstrato a que a teoria dualista veda a possibilidade de constituírem objeto de um juízo autônomo, como

\footnotetext{
${ }^{149}$ Nesse sentido, PIERO CALAMANDREI afirma serem duas características que definem a jurisdição: a substitutividade à atuação espontânea das partes, e a declaratividade do direito incidente. (Limiti fra giurisdizione e amministrazione nella sentenza civile. In: CAPPELLETTI, Mauro (a cura di). Opere giuridiche. Napoli: Morano, 1965. v. 1, p. 65-93).

${ }^{150}$ Ainda DINAMARCO, op. cit., afirma que "o mais agudo sintoma de uma tomada de posição da lei brasileira em face das duas teses em exame é o instituto da coisa julgada" (Direito e processo, cit., p. 87).

${ }^{151}$ A abstração da concepção dualista é precisamente a crítica de SALVATORE SATTA, um dos mais destacados defensores da teoria unitária: "Ė, como si vede, tutto un lavoro di astrazione, cha ha i suoi pregi, specie da un punto di vista didatico, ma che dimentica una cosa sola: che il diritto vivel nel concreto, à anzi il concreto stesso, e pertanto la norma è ordinamento soltanto in quanto effetivamente un ordine si stabilisca (...). Amesso questo, riconnosciuto che il diritto, sia oggettivo che soggettivo, esiste solo nel concreto, il problema è quello di stabilire come il concreto si forma: e a questa domanda noi abbiamo già dato una risposta quando abbiamo parlato dela giurisdizione, mettendo in rilievo l'indissociabilità della legge dall'azione, nella quale la prima trova appunto la sua concretezza, e quindi la sua esistenza" (SATTA, Salvatore; PUNZI, Carmine. Diritto processuale civile. 13. ed. Padova: CEDAM, 2000. p. 130-131).

${ }^{152}$ CAPPELLETTI, Mauro. Juízes legisladores? Trad. de Carlos Alberto Alvaro de Oliveira. Porto Alegre: Sérgio Antonio Fabris, 1993.

${ }^{153} \mathrm{E}$ apenas coerente com a premissa da unicidade do ordenamento a ampla liberdade que CARNELUTTI sustenta assistir ao autor em fragmentar a lide, deduzindo-a de forma integral ou parcial no processo (CARNELUTTI, Francesco. Lezioni di diritto processuale civile. Padova: La Litotipo, 1927. v. 4).
} 
fundamentos de fato e direito, ou fragmentos de relações jurídicas, passam a ser suscetíveis de proteção pela coisa julgada ${ }^{154}$.

Para que possamos optar entre essas opiniões é necessário prosseguirmos na análise da formação política do moderno Estado de direito, para identificar os traços que por ele foram destinados à jurisdição. Com efeito, se nos limitarmos aos pólos metodológicos da ação (escola italiana) ou do objeto litigioso do processo (escola germânica), que se limitam ao tratamento politicamente neutro, formal e sistemático de seu objeto de estudo ${ }^{155} 156$ (característico da influência da ideologia positivista ${ }^{157}$ sobre a dogmática jurídica no século passado), poderemos optar por qualquer uma dessas alternativas, pois ambas são aceitáveis em abstrato, a partir das premissas que propõem a si mesmas. É por essa razão que vem se mostrando profícua a opção, própria da fase instrumental dos estudos processuais, de

\footnotetext{
${ }^{154} \mathrm{~A}$ teoria unitária do ordenamento, e a correspondente concepção substancial da coisa julgada, exercem reflexos importantes para a disciplina da limitação objetiva e subjetiva da coisa julgada, e permitem a incidência da coisa julgada sobre pontos de fato ou direito que não estão associados a uma determinada tutela jurídica. Esses reflexos podem ser sentidos nas teorias de ENRICO REDENTI e de GIOVANI PUGLIESE sobre a coisa julgada, que examinaremos no último capítulo.

${ }^{155}$ Muito interessante, a respeito, é a associação que JUAN MONTERO AROCA estabelece entre a neutralização política do direito processual e a ascensão dos governos fascista e nazista na Itália e na Alemanha. O abandono do estudo da jurisdição teria dado em um duplo sentido: "por um lado em los planes de estúdios el professor de Derecho procesal queda relevado de explicar todo lo relativo a la jurisdicción. Ejemplo destacado de ello se encuentra en Italia, donde em 1935 de Procedura civile e Ordinamento giudiziario se pasó unicamente a Procedura civile, que se convertió em 1936 em Diritto processuale civile. Los italianos han bromeado em torno al $<<$ cambio de sexo $>>$ de su disciplina, pero no creo que hayan insistido lo suficiente em lo significativo que fueron las fechas em que el legislador fascista les apartó de la explicación académica de todos los problemas relativos al Poder Judicial. Por otro lado, mucho más grave ha sido que los procesalistas abandonaran voluntariamente ese campo. (...)" (MONTERO AROCA, Juan. El derecho procesal en el siglo XX, cit., p. 34-35).

${ }^{156} \mathrm{Em}$ relação ao estudo da ação houve correntes - concretistas e ecléticas - que buscaram enfatizar os fins do processo, associando o conteúdo do direito de ação ao direito material. Entretanto, essas conceituações levam a problemas lógicos que constituíram o objeto de infindáveis polêmicas, na medida em que não se conseguia explicar a natureza de ação nas sentenças de improcedência, ao passo em que se flertava com o imanentismo da ação frente ao direito processual. Essas teorias demonstravam preocupação com um elemento de grande importância, que é o compromisso do processo com a efetividade da ordem jurídica justa. O seu problema, no entanto, era de perspectiva, porque a efetivação da ordem jurídica é uma finalidade da jurisdição, cujo estudo foi relegado a um segundo plano no contexto da "neutralização política" do processo. BOTELHO DE MESQUITA, a propósito, analisa a influência dos regimes nacional socialista e fascista sobre o processo, destacando que "no que respeita à ação, manifestou-se a tendência de reduzir o direito de ação ao direito ao processo; e do direito à proteção jurídica (Rechtschutzanspruch) a uma mera expectativa de tutela jurídica (Anrecht auf Rechtschutz)" (As novas tendências do direito processual: contribuições para seu reexame, cit., p. 272).

${ }^{157}$ A ideologia positivista não pode ser confundida com a teoria positivista do direito. A diferença que se estabelece entre essas duas manifestações do positivismo, conforme explica NORBERTO BOBBIO, está em que enquanto a teoria positivista busca descrever o direito de maneira neutra, a ideologia positivista visa a influir sobre o direito por meio da idéia de que há um dever moral de obedecer ao direito enquanto tal $(O$ positivismo jurídico: lições de filosofia do direito, cit., p. 222 e ss.). A propósito da relação estabelecida pela nota de rodapé retro, cabe acentuar que o essa ideologia positivista, em seu aspecto mais radical, orientado pela concepção de que o Estado tem uma missão histórica a realizar (estatolatria), é igualmente associada aos regimes nazista e fascista (idem. p. 229), com a ressalva de que essa mesma ideologia, em seu aspecto mais moderado - preocupado em assegurar a ordem social pelos valores da generalidade e abstração do direito - "não leva em absoluto à estatolatria ou ao totalitarismo político" (idem, p. 236).
} 
adotar como pólo metodológico o conceito de jurisdição $o^{158}$, na acepção de função estatal ${ }^{159}$ destinada a compor os conflitos com justiça. A jurisdição, segundo o arranjo institucional vigente em nosso país, visa a atender uma série de escopos de interesse público ${ }^{160}$. E para nos posicionarmos a respeito das relações que se estabelecem entre o juiz e a lei, interessa particularmente o escopo jurídico, isto é, qual a posição que a jurisdição assume no processo de produção e imposição de normas pelo Estado de Direito ${ }^{161}$. Nesse sentido, a posição do juiz em face do legislador é determinada pelo sistema de legitimação política do direito que é característico do Estado moderno.

A idéia de que a função da jurisdição consiste na aplicação de um direito preexistente deriva da idéia do primado da lei, característico do liberalismo político clássico, combinada à doutrina da divisão dos poderes. Sucedendo os regimes absolutistas,

\footnotetext{
${ }^{158} \mathrm{~A}$ ênfase na jurisdição é uma nota distintiva das Escolas de direito processual latino-americanas. HUGO ALSINA, por exemplo, define o direito processual como "el conjunto de normas que regulan la actividad jurisdiccional del Estado" (Tratado teorico practico de derecho procesal civil y comercial. 2. ed. Buenos Aires: Ediar, 1956. p. 35), sendo grande o destaquye que EDUARDO COUTURE veio dar ao tema em seus Fundamentos del derecho procesal civil, cit. No Brasil, CÂNDIDO RANGEL DINAMARCO entende que a jurisdição é o centro ao qual convergem todos os demais institutos fundamentais do processo, afirmando que "a preponderância metodológica da jurisdição, ao contrário do que se passa com a preferência pela ação ou pelo processo, corresponde à preconizada visão publicística do sistema, como instrumento do Estado, que ele usa para o cumprimento de objetivos seus" (A instrumentalidade do processo. 13. ed. São Paulo: Malheiros Ed., 2008. p. 95). Na Espanha, JUAN MONTERO AROCA vem propondo inclusive a mudança da denominação da disciplina para "direito jurisdicional", na medida em que o processo não é seu o único e nem o seu mais importante conceito; "ahora bién, si se trata de identificar uma rama jurídica atendendo a su concepto principal, que es el poder judicial o jurisdicción, y no a um concepto subordinado, que és el processo, dígase de uma vez: derecho jurisdicional”. (MONTERO AROCA, Juan. Derecho jurisdiccional. 10. ed. Valencia: Tirant lo Blanch, 2000. v. 1, p. 23).

${ }^{159} \mathrm{~A}$ jurisdição tradicionalmente é estudada sob as perspectivas: a) do poder em que é investido o órgão jurisdicional; b) da atividade por ele exercida; c) da função que desempenha. Como explicam ANTONIO CARLOS DE ARAÚJO CINTRA, ADA PELLEGRINI GRINOVER e CÂNDIDO RANGEL DINAMARCO, a jurisdição "como poder, é manifestação do poder estatal, conceituado como capacidade de decidir imperativamente e impor decisões. Como função, expressa o encargo que têm os órgãos estatais de promover a pacificação de conflitos interindividuais, mediante a realização do direito justo e através do processo. E como atividade ela é o complexo de atos do juiz no processo, exercendo o poder e cumprindo a função que a lei lhe comete" (Teoria geral do processo. 22. ed. São Paulo: Malheiros Ed., 2006. p. 145). As duas primeiras acepções estão ligadas mais à técnica processual do que aos fundamentos do processo. A última, em contraste, por dizer respeito às finalidades do direito processual e sua inserção no quadro do poder estatal, nos parece a mais complexa e a mais importante dessas acepções.

${ }^{160} \mathrm{De}$ acordo com a tese de CÂNDIDO RANGEL DINAMARCO, essas finalidades poderiam ser agrupadas em três grandes grupos: escopos políticos, escopos sociais e escopo jurídico. (A instrumentalidade do processo, cit.).

${ }^{161}$ Colocando em perspectiva as diversas finalidades do processo enumeradas pela $A$ instrumentalidade do processo, cit. de CÂNDIDO DINAMARCO, parece-nos ter razão JOSÉ ROBERTO DOS SANTOS BEDAQUE ao afirmar a preeminência do escopo jurídico frente aos demais. Diz ele que "para caracterização da jurisdição, não é insuficiente considerar apenas o escopo jurídico desse instituto. Escopos sociais e políticos são meras conseqüências da correta incidência da regra de direito material. Na medida em que a lei representa a vontade social, atuada ela no caso concreto haverá pacificação com justiça. Estará afirmada a autoridade do Estado. Além do mais, colocar a participação e a educação como escopo político e social da jurisdição significa superdimensioná-la, em detrimento das funções legislativa e executiva, a quem competem realmente tais atribuições" (Poderes instrutórios do juiz. 4. ed. São Paulo: Ed. Revista dos Tribunais, 2009. p. 31).
} 
as revoluções liberais que marcaram a primeira fase da era moderna na Europa tiveram por objetivo a limitação do poder, de modo a prevenir o ressurgimento de governos despóticos, bem como os entraves que eles causavam ao mercantilismo e à nova economia que então surgia. Inspirava a teoria política dessa época o contratualismo de HOBBES e LOCKE, segundo o qual o governo deveria ser baseado no consentimento dos indivíduos, orientado pela idéia da igualdade política entre os cidadãos, retomada do ideário clássico grecoromano. RoUSSEAU desenvolveria a tese de que esse consentimento deveria se expressar em leis, dotadas dos atributos de clareza, racionalidade, impessoalidade e generalidade, que representassem a vontade geral do povo ${ }^{162}$. Entretanto, pela inviabilidade prática da elaboração dessas leis em assembléia geral dos cidadãos, o ideal democrático se adapta à idéia de governo representativo ${ }^{163}$, em que a vontade popular é delegada a um parlamento, que dessa maneira ganha a legitimidade para deliberar em nome do povo. E o quadro veio a se completar com a doutrina da divisão dos poderes de MONTESQUIEU, segundo a qual apenas o poder teria condições de limitar o poder, de modo que seu exercício haveria de ser repartido entre ramos autônomos entre si, dotados das faculdades de instituir e de vetar uns frente aos outros. E assim se concebeu a idéia da separação entre os Poderes Legislativo, Executivo e Judiciário, entregando-se a cada um deles autonomia para desempenhar suas funções típicas. Ao primeiro caberia elaborar as leis que disciplinam a vida em sociedade; ao segundo cumpriria executar as tarefas de interesse geral cometidas pela lei, e ao judiciário caberia aplicar a lei na resolução dos conflitos entre os indivíduos. Dessa forma, a jurisdição foi definida como a função típica de aplicar o direito, concebido em caráter geral e abstrato pelo legislador, a casos concretos ${ }^{164}$. A dualidade do

\footnotetext{
162،“...) vê-se com clareza que já não é preciso perguntar a quem compete fazer as leis, visto serem atos da vontade geral, nem se o Príncipe está acima da lei, visto ser membro do Estado, nem se a lei pode ser injusta, porquanto ninguém é injusto para consigo mesmo, nem como se é livre e ao mesmo tempo submisso às leis, já que estas são meras expressões de nossa vontade" (ROUSSEAU, Jean Jacques. $O$ contrato social. 3. ed. São Paulo: Martins Fontes, 1996. p. 47).

${ }^{163}$ A doutrina do governo representativo foi defendida com particular vigor por JOHN STUART MILL, para quem "(...) nothing less can be ultimately desirable than the admission of all to share in the sovereign power of the state. But since all cannot, in a community exceeding a single small town, participate personally in any but so very minor portions of the public business, it follows that the ideal type of a perfect government must be representative (Considerations on representative government. Rockville, Maryland: Serenity Publishers, 2008. p. 49). Também a respeito vide MONTESQUIEU, para quem apenas os representantes teriam o preparo para discutir os assuntos de Estado ( $O$ espírito das leis. 2. ed. São Paulo: Martins Fontes, 2006).

${ }^{164}$ Como sintetiza CELSO NEVES, “o objeto do processo passou a transcender do simples direito subjetivo, para fazer-se instrumento de realização do direito objetivo. $\mathrm{O}$ interesse público passa à frente do interesse privado, para assegurar o poder normativo das leis, na sua função de precompor os conflitos de interesses. (...) A finalidade primordial do processo está, pois, na realização do interesse público de que se efetive o comando normativo das leis, através da qual se realiza, por via de consequiência, o interesse privado". (Contribuição ao estudo da coisa julgada civil. Tese (Cátedra). Faculdade de Direito, Universidade de São Paulo, São Paulo, 1970. p. 439-440).
} 
ordenamento jurídico, assim, está assentada sobre as bases de legitimidade da organização política de nossa sociedade, que confere uma primazia ao legislador.

Ainda assim, a constatação de que o juiz exerce poderes que são, em grande medida, discricionários, tem colocado em questão a visão dualista do ordenamento. A dinâmica da jurisdição na sociedade atual tem de fato uma complexidade muito maior do que sugere a bibliografia que visava a afirmar a autonomia do processo, e a própria evolução do direito no século passado veio a deixar isso em evidência. Nesse sentido, já fizemos referência no primeiro capítulo deste trabalho às transformações por que passou a sociedade no século XX, bem como ao modo como a atuação dos corpos intermediários e grupos de pressão sobre o legislador, combinadas com a expansão do regulamento administrativo, deram origem a uma normatividade caótica, transitória e incoerente, ao mesmo tempo conflitante e lacunosa, que em nada lembra o ideal da legislação racional dos autores iluministas. Em meio a essa "inflação legislativa", o povo perdeu contato com a lei e o conceito de representatividade se viu corroído. Ao mesmo tempo, incapaz de dar respostas às demandas conflitantes da sociedade em torno da distribuição dos riscos, o próprio legislador se valeu de técnicas como as cláusulas abertas ou conceitos-válvula, que delegaram aos juízes uma grande margem de escolha para a definição da regra concreta de decisão.

Tudo isso está na base da formação do assim chamado "direito jurisprudencial"165, movimento de alcance global pelo qual o Poder Judiciário assume de forma cada vez mais proeminente escolhas entre os valores em conflito, com uma grande ampliação de sua discricionariedade. Nessa nova realidade, tornaram-se necessários a retomada dos estudos de técnicas de interpretação do direito e da argumentação, bem como o desenvolvimento da teoria dos princípios, normas flexíveis capazes de estabelecer um eixo coerente para lidar com a fragmentação dos subsistemas normativos, por meio de técnicas como a ponderação de valores e a concretização da lei ${ }^{166}$. Cada vez mais se tornou evidente que os

\footnotetext{
${ }^{165}$ Obra de referência no assunto é o ensaio de MAURO CAPPELLETTI, Juízes legisladores?, cit., em que o autor descreve de maneira entusiasmada a expansão da criação judicial do direito, pendendo inclusive para uma visão unitária do ordenamento. Em um trabalho de teor mais descritivo, NICOLA PICARDI alude, por meio de uma paráfrase a um conhecido ensaio de SAVIGNY sobre as grandes codificações do século XIX, à "vocação de nosso tempo para a jurisdição" (A vocação de nosso tempo para a jurisdição. In: Jurisdição e processo. Rio de Janeiro: Forense, 2008. p. 1-32).

${ }^{166} \mathrm{O}$ papel dos princípios na interpretação do direito contemporâneo foi objeto de extensos desenvolvimentos recentes por autores como RONALD DWORKIN (Taking rights seriously. Cambridge, Massachussets: Harvard University Press, 1979. p. 94 e ss.) e ROBERT ALEXY (Teoría de los derechos fundamentales. 2. ed. Madrid: Centro de Estudios Políticos e Constitucionales, 2007. p. 63 e ss.). Na figura do juiz da Supre
} 
juízes estavam em uma larga medida a criar o direito, ao decidir os casos concretos que lhes chegavam às mãos.

Este cenário nos põe à frente a questão de saber se permanece válida a idéia de dualidade do ordenamento, segundo a qual o juiz tem um papel secundário de criação normativa, delimitado e conformado pelo direito legislado. A esse propósito, entendemos que MiCHELLE TARUFFO foi ao cerne do problema quando afirmou que justamente porque há uma margem de discricionariedade na interpretação da lei é que se reforça a necessidade de que a decisão seja fundada em parâmetros racionais que possam ser conduzidos ao texto da lei ${ }^{167}$, até mesmo mais por razões éticas e políticas do que propriamente jurídicas. O critério da legalidade tem um importante papel legitimador da jurisdição e do poder estatal, como bem demonstrou NIKLAS LUHMANN em sua análise do problema a partir da sua visão da teoria dos sistemas, pois é ele o parâmetro que permite ao sistema jurídico reduzir a complexidade do ambiente exterior (diferenciando-se dos sistemas da moral e da política), condicionando as expectativas das partes e induzindo a sua aceitação da decisão ${ }^{168}$. Além disso, na medida em que as diferentes Constituições, ao

Corte de Israel, AHARON BARAK, é pela interpretação - um papel secundário de produção normativa que os juízes estabelecem as pontes entre a lei e a sociedade (The judge in a democracy, cit., p. 5).

167، “...) proprio nel momento in cui si riconosce la natura creativa del ragionamento decisorio emerge con particolare evidenza la necessità - tipica dello Stato di diritto fondato sul principio di lagalità - che questa creazione avenga secondo criteri di racinalità, e sia riconducibile entro il contesto - dinamico finché si vuole, ma non privo di ordine - dell'ordinamento" (TARUFFO, Michele. Legalità e giustificazione della creazione giudiziaria del diritto. In: ___ Sui confini: scritti sulla giustizia civile. Bologna: Il Mulino, 2002. p. 216). Dessa forma, como já havia sido observado anos antes por ENRICO TULLIO LIEBMAN, o fato de existir um componente criativo na atividade do juiz não significa que a sua decisão não esteja vinculada à lei. Em comentário ao ensaio de CAPPELLETI sobre a criação judiciária do direito, afirma ele que a concepção de que a atividade do juiz é criativa é apenas parcialmente correta "Do ponto-de-vista sociológico, filosófico e político, e na visão do homem leigo, a resposta seria: sim, no ato jurisdicional há sempre qualquer coisa, mais ou menos relevante, que não está na lei, a começar pelo caráter concreto da regra enunciada conteúdo da decisão, até as escolhas mais ou menos numerosas que a tomada de decisão reclamou. Mas do ponto-de-vista jurídico as coisas ocorrem de forma absolutamente diversa, porque o ângulo jurídico não pode prescindir do elemento formal e por isso o pronunciamento do juiz consiste exclusivamente em tornar explícito, manifesto e concreto aquilo que já estava contido na formulação do preceito legislativo. E o elemento formal não consiste em algo de indesejável que por vezes o autor pretende ignorar. As sentenças decidem sobre a liberdade, sobre direitos e interesses das pessoas e a força da lei é a única defesa, a única garantia e proteção que lhes é assegurada, na medida do possível, a "certeza do direito", e que exclui, o quanto viável, o arbítrio do juiz no momento em que julga o seu semelhante em assuntos que dizem respeito à sua personalidade e aos seus bens. A lei é a lei, e o juiz a ela se submete (art. 101, alínea 2, da Constituição Italiana), não podendo completá-la ou integrá-la, mas somente aplicá-la, o que quer dizer, tornar claro, concretizar, explicitar, o que o ordenamento jurídico já contém, embora de forma abstrata." (A força criativa da jurisprudência e os limites impostos pelo texto da lei. Revista de Processo, São Paulo, n. 43, p. 57-60, jul./set. 1986).

168“"A canalização e controle das influências sociais através da legislação, portanto a positivação do direito, constitui uma condição prévia essencial da autonomia social da evolução legal da decisão. $O$ juiz retira o seu parecer do direito escrito, onde se definem quais são os fatos e qual o sentido em que são relevantes para a decisão e não já diretamente a idéia do verdadeiro e do justo que lhe foram impostas numa organização visualizada da vida social. Assim ele pode operar com um afastamento maior e não está obrigado, em todos os assuntos muito diversificados sobre os quais tem de decidir, a adivinhar os princípios 
organizarem a distribuição e a forma de exercício do poder estatal, vinculam a jurisdição à proteção contra a violação ou ameaça a direitos (como é o caso da Carta de 1988: art. $5^{\circ}$, inciso XXXV), o postulado da dualidade do ordenamento, baseado na legalidade, passa a integrar também o campo do direito político de uma maneira tal que não pode ser ignorada pelas teorias da jurisdição e do processo.

E somos assim levados a concluir que a impostação tradicional da polêmica em torno do papel dos juízes em face da lei, que opõe a livre criação do direito pelos juízes (como teoria unitária do ordenamento) à sua aplicação puramente declarativa (como teoria dualista) colocou mal os termos da questão, pois o que se verifica é que o juiz em parte exerce amplos poderes discricionários que lhe são reconhecidos pela lei, mas ao mesmo tempo deve seguir os parâmetros que ela lhe impõe ao decidir cada conflito, se não quiser comprometer sua própria independência. Como afirma EDUARDO COUTURE, nesse estreito sentido se pode dizer que a atividade jurisdicional é criativa, mas a sua finalidade é assegurar a efetividade da Constituição e das leis ${ }^{169}$. O que se tem, portanto, está situado a meio-termo das duas posições extremas: a lei estabelece limites à discricionariedade judicial, para que a jurisdição não seja exercida de forma arbitrária, mas ao mesmo tempo - por não comportar a previsão exaustiva de todas as situações de conflito que podem ocorrer na vida em sociedade - ela própria outorga, e de maneira cada vez mais freqüente e intensa conforme aumenta a complexidade da contemporânea, uma margem de escolhas discricionárias aos juízes. Tudo isso não invalida a premissa de que a decisão jurisdicional tem natureza secundária e subordinada ao direito preexistente, assumindo assim uma função eminentemente declarativa. E é a partir dessa premissa que se desenvolve a técnica processual.

morais do parecer que sejam susceptíveis de consenso. Ele pode e deve decidir como um estranho" (LUHMANN, Niklas. Legitimação pelo procedimento. Brasília: Ed. Universidade de Brasília, 1980. p. 56). Nessa linha, CELSO FERNANDES CAMPILONGO destaca que, sendo abandonado esse código próprio, o direito perderia suas referência internas e suas formas de distinção com o ambiente, deixando de se constituir em uma estrutura social diferenciada e, portanto, perderia a capacidade de lidar com a sua complexidade (Política, sistema jurídico e decisão judicial, cit., p. 127).

169“"El fin de la jurisdicción es asegurar la efectividad del derecho. En el despliegue jerárquico de preceptos, propio de la normatividad, la jurisdicción asegura la continuidad del orden jurídico. Es, en ese sentido, un medio de producción jurídica. El derecho instituído en la Constitución se desenvuelve jerárquicamente en las leyes; el derecho reconocido en las leyes, se hace efectivo en las sentencias judiciales. Esto asegura no sólo la continuidad del derecho, sino también su eficacia necesaria". (COUTURE, Eduardo. Fundamentos del derecho procesal civil, cit., p. 37). 


\subsubsection{O conceito de tutela jurisdicional e a relação jurídica como "entidade mínima estrutural" do objeto litigioso do processo}

Vimos como a jurisdição moderna, refletindo o princípio da separação das funções estatais, foi construída sobre o pressuposto de uma concepção dualista do ordenamento jurídico, em que a ação e o processo são autônomos frente ao direito material. A consciência dessa separação é de uma importância fundamental para que bem possamos distinguir institutos do direito material daqueles de direito processual, e assim compreendermos de que maneira e em quais limites se manifestam as respectivas eficácias, quais os seus regimes de invalidades, e em que medida eles podem ou não se influenciar mutuamente.

No entanto, assim que enxergamos a autonomia do processo, voltamos nossas atenções novamente para o direito material, pois é em função dele que existe e se desenvolve cada relação processual. Pois embora direito material e direito processual sejam conceitualmente separados, na realidade prática eles se apresentam sempre entrelaçados ${ }^{170}$ e em relação de estreita conexão funcional, dado o caráter instrumental que o processo assume no moderno Estado de direito. Como adverte José ROBERTO DOS SANTOS BedAQUe, "a natureza instrumental do direito processual impõe sejam seus institutos concebidos em conformidade com as necessidades do direito material. Isto é, a eficácia do sistema processual será medida em função de sua utilidade para o ordenamento jurídico material e para a pacificação social"171. Em outras palavras, a autonomia do processo não deve ser confundida com seu isolamento frente ao direito material que ele está destinado a assegurar.

A coordenação entre direito material e direito processual foi gradualmente refinada pela ciência do processo, principalmente a partir do estudo da ação e do objeto litigioso, que foram os dois pólos metodológicos de maior destaque na processualística no século

\footnotetext{
${ }^{170}$ Como assinala BOTELHO DE MESQUITA, “o que se haverá de considerar, para a compreensão do fenômeno jurídico em sua totalidade, há de ser a ordem jurídica como uma unidade incindível, em face da qual não subsistem isoladamente categorias que se pretendiam não só diversas, mas também independentes, como as de direito subjetivo, ação, processo, jurisdição, obrigação, ou de direito público e privado, material instrumental e assim por diante" (Da ação civil. In:___. Teses, estudos e pareceres de processo civil: direito de ação - partes e terceiros - processo e política. São Paulo: Ed. Revista dos Tribunais, 2005. v. 1, p. 123). A autonomia científica do processo, necessária para o correto manejo das relações jurídicas pertinentes à atividade jurisdicional, não deve levar o intérprete a considerá-lo de forma isolada do fenômeno jurídico externo em que se insere.

${ }^{171}$ BEDAQUE, José Roberto dos Santos. Direito e processo. 4. ed. São Paulo: Malheiros Ed., 2006. p. 17.
} 
$\mathrm{XX}$. Alguns dos primeiros autores que se preocuparam com a finalidade do processo, como WACH e CHIOvENDA, adotaram uma concepção que vinculava estreitamente a ação ao direito material, enxergando-a como uma decorrência deste. Essa visão da ação, que passou a ser conhecida como teoria concretista, como se sabe, foi repelida pela doutrina posterior iniciada por DEGENKOLB, que com razão veio a afirmar que o direito público da ação, assegurado a todos pelo Estado, não poderia ser condicionado a ter ou não razão o autor. A teoria abstrata do direito de ação, entretanto, em razão de seu caráter excessivamente indefinido, acaba por perder de vista a posição instrumental do processo frente aos demais direitos. Por essa razão, os processualistas que mais recentemente voltaram a examinar o problema da ação, sem incorrer no estabelecimento de uma relação direta como fizeram os concretistas, vieram a defender que o conteúdo do direito de ação deve ser a afirmação de um direito, cuja concretização é a finalidade do processo. É essa a posição que foi defendida há alguns por CELSO NEvES ao descrever a Estrutura fundamental do processo civil ${ }^{172}$ e por José IGNÁCIO Botelho DE MESQUiTA em sua tese sobre $A$ ação civil $^{173}$; e que foi recentemente retomada por LUIZ GUILHERME MARINONI, ao tratar do tema da tutela jurisdicional ${ }^{174}$.

Paralelamente, a vertente germânica do processo, que adotava o objeto do processo como elemento central de suas pesquisas, caminhava para atingir resultados semelhantes, influenciada pelo §253, II, da ZPO, que determina que a petição inicial deve expor os fundamentos da pretensão (Grundes des Anspruch) deduzida em juízo. É verdade que bem cedo WACH distinguiu esse conceito de pretensão processual - a pretensão à tutela jurídica pelo Estado - da pretensão civilística, conceito desenvolvido por WINDSCHEID e levado ao $\S 194$ do BGB, consistente no poder de exigir um comportamento alheio. Com isso, WACH

\footnotetext{
${ }^{172}$ A ação, para CELSO NEVES, "não tem vínculo elementar com o direito subjetivo material, mantendo, com este, relação de instrumentalidade mediata. Topologicamente, pertence ao Direito Público, subjetivando-se, ativamente, em quem exige a tutela jurídica processual e, passivamente, no Estado eu detém o poder dever de prestá-la. Seu elemento objetivo, portanto, é essa tutela, teleologicamente voltada, imediatamente, para a realização do direito objetivo e, mediatamente, à efetivação do direito subjetivo do litigante" (Estrutura fundamental do processo civil. Rio de Janeiro: Forense, 1997. p. 115-116).

${ }^{173}$ Nessa tese, que retoma a conexão entre direito e processo presente na teoria concretista, sem, contudo, condicionar a ação à existência do direito subjetivo, BOTELHO DE MESQUITA a define como "o direito à realização da ordem jurídica, por meio da atividade do Estado. É um direito subjetivo público, dirigido contra o Estado, a quem incumbe o dever de, pela atividade de seus órgãos jurisdicionais, tornar efetiva a ordem prevista na lei" (Da ação civil, cit., p. 121-122).

${ }^{174} \mathrm{Na}$ linha da tradição citada nas notas anteriores, MARINONI propõe que o direito à tutela jurisdicional deve estar comprometido com a efetiva proteção do direito material: “(...) deseja-se propor, nesse momento, que o direito à tutela jurisdicional, ainda que sem perder sua característica de direito de iguais oportunidades de acesso à justiça, passe a ser visto como o direito à efetiva proteção do direito material, do qual são devedores o legislador e o juiz, que então passa a ter um verdadeiro dever de se comportar de acordo com o direito fundamental à efetividade da tutela jurisdicional" (Técnica processual e tutela dos direitos, cit., p. 147).
} 
deixava claro que a pretensão à tutela jurídica não é emanação do direito privado, em face do qual ostenta uma completa independência.

Assim, o fato de a jurisdição ter como escopo jurídico a aplicação do direito material preexistente, em uma atividade que - adotemos uma simplificação - pode ser descrita como a verificação da ocorrência concreta de fatos anteriormente previstos em uma hipótese normativa geral e abstrata, para a determinação do efeito jurídico correspondente, gera uma conseqüência prática da maior importância para o regime jurídico do objeto litigioso do processo e para a coisa julgada: a de que toda pretensão processual deve ter, por unidade mínima estrutural, uma relação jurídica tutelada pelo processo $^{175}$. Trata-se de uma limitação ao princípio dispositivo, que não permite ao autor fracionar o objeto do processo em aspectos inferiores àqueles que determinam a estrutura do direito que se visa a proteger. Em outras palavras, se a função da jurisdição é a aplicação do direito ao caso concreto, a não ser que exista uma excepcional previsão legislativa, segue que ao formular sua demanda - cujo conteúdo é o pedido de tutela a um bem jurídico - o autor não pode se limitar a pedir esclarecimento sobre algum aspecto ou outro da incidência normativa, ou pedir ao juiz que determinadas questões que possam influir no juízo de incidência normativa sejam reservados para eventual discussão futura, de modo a que se obtenha um julgado hipotético. Ele é obrigado a deduzir uma relação jurídica concreta como fundamento ao postular, como pretensão, um provimento adequado à proteção do direito que se afirma ter sido violado ou ameaçado. No direito positivo, essa regra pode se depreender do artigo $4^{\circ}$, inciso I, do Código de Processo Civil, segundo o qual a ação declaratória deve ter por objeto ao menos a existência ou inexistência de

\footnotetext{
${ }^{175}$ Nesse sentido, GIOVANNI VERDE afirma que "l'attore non è libero nel determinare l'oggetto della domanda, ma tale oggetto deve necessariamente rapportare ad una sorta di $<<$ minima unità strutturale $>>$ desumibile dalla disciplina sostanziale della situazione controversa" (Sulla $<<$ minima unità sttruturale $>>$ azionabile nel processo: (a proposito di giudicato e di dottrine emergenti). Rivista di Diritto Processuale, Padova, p. 582, 1989). SÉRGIO MENCHINI sublinha que essa unidade mínima consiste em um limite ao princípio dispositivo, decorrente do fato de que o processo deve estar vinculado à tutela de um direito substancvial: "il principio dispositivo non possa essere inteso nel senso di attribuire all'attore il potere di disporre non soltanto della situazione sostanziale, ma anche dell'oggetto del processo. Il legislatore concede sì al privato la più ampia facoltà di disposizione, anche in riguardo al momento della tutela giurisdizionale, in ordine al diritto sogettivo, ma non accorda a lui alcuna facoltà circa la nozione e l'estensione della res da dedurre in giudiuzio. Il concetto e l'ampiezza dell'oggetto del processo non sono rimessi alla disponibilità delle parti e 'l'entità minima strutturale' è constituita dal diritto soggettivo, sia pure meramente affermato, nella sua totela consistenza sostanziale, per cui non si può riconoscere all'attore il potere né di scindere l'unitaria pretesa ad una prestazione pecuniaria in più domande parziali quanto al petitum, né di limitare l'oggetto del giudicato ad uno specifico titolo d'acquisto." (Il giudicato civile. Torino: UTET, 2002, grifos nossos, p. 35-36).
} 
relação jurídica ${ }^{176}$, não se admitindo a pretensão de declaração de fatos aos quais a lei não atribua consequiência alguma.

Tampouco se admite ordinariamente a fragmentação da pretensão em seus elementos constitutivos, se não constituírem tais elementos, eles próprios, pretensões autônomas ${ }^{177}$. Assim, por exemplo, não se pode admitir uma demanda em que o autor pretenda a declaração de que o réu agiu culposamente em determinada ocasião, sem que esse fato seja apurado apenas na qualidade de fundamento para a determinação de um efeito jurídico em concreto (tipicamente, a condenação na reparação de danos). As razões para isso não são difíceis de serem compreendidas. Tomemos como exemplo uma ação fundada em responsabilidade civil e consideremos em separado um dos elementos que pressupõem responsabilidade, como a culpa do agente. A culpa somente pode ser avaliada no contexto das normas de responsabilidade civil, e uma mesma conduta pode ser considerada regular ou imprudente a depender da natureza da relação entre as partes e do regime específico de responsabilidade a que elas se submetam. Sob outras regras, a culpa sequer será necessária, e o nexo causal já será suficiente à responsabilização. Em suma, as questões pertinentes a uma determinada pretensão não têm como assumir uma qualificação genericamente aplicável para todas e quaisquer finalidades, pois cada fato deverá ser sopesado e qualificado à vista da hipótese normativa pertinente a cada pedido específico de tutela $^{178}$. O processo, atualmente se tem consciência, não poderá jamais atingir a verdade sobre os fatos através de sua discussão exaustiva, de modo que sua apreciação será necessariamente instrumental e funcionalizada à investigação da existência ou inexistência da relação jurídica sustentada pelo autor.

\footnotetext{
${ }^{176} \mathrm{O}$ inciso II do mesmo artigo $4^{\circ}$ permite a ação declaratória de autenticidade ou falsidade de documento. Ao contrário do que a redação sugere, nos parece que também aqui não se trata de declaração do fato da falsidade (o que dificilmente se justificaria do ponto do interesse processual), mas antes de pretensão à declaração ou desconstituição da eficácia probante do documento, das quais a autenticidade ou a falsidade são meros fundamentos.

${ }^{177}$ Nas excepcionais hipóteses em que se permite a dedução de pedido genérico (art. 287, do Cód. de Processo Civil; art. 95, da Lei $n^{\circ}$ 8.078/90), que serão examinadas no último capítulo, essa fragmentação ocorre ao menos de forma aparente. Teremos oportunidade de verificar que a legislação processual é extremamente restritiva em admitir esse tipo de pedido e adota cautelas para que o provimento seja dado sempre à vista de um caso concreto e de uma pretensão definida.

${ }^{178}$ Por conseqüência, o princípio da ampla defesa pressupõe que o réu tenha oportunidade de se manifestar quanto à subsunção dos fatos a cada hipótese normativa pertinente à pretensão que contra ele se dirigiu, e de conhecer as possíveis repercussões de um julgamento desfavorável em torno daquela questão. Tal aspecto é bem levado em consideração por ANDREA PROTO PISANI, para quem “(...) se fosse possibile l'accertamento giudiziale dello fatto storico, oppure l'accertamento della norma giuridica, si avrebbe in concreto la limitazione del diritto di difesa del convenuto. Posto, infatti, che il fatto storico è fonte di una serie indefinita di fattispecie e come tale può essere rilevante ai fini di più e diversissimi effetti giuridici, se non viene precisato quale sia la fattispecie con riferimento alla quale si agisce, il convenuto non saprebbe qual è il bene della vita su ciui l'accertamento è destinato ad incidere" (Lezioni di diritto processuale civile. Napoli: Jovene, 1996. p. 139).
} 
Estabelecido que o elemento estrutural mínimo da pretensão processual é a relação jurídica cuja tutela é solicitada do Estado, por derivação segue que a coisa julgada também terá por elemento mínimo a manifestação sobre a existência ou inexistência do efeito jurídico derivado da afirmada incidência da lei, sobre o suporte fático concreto que define o caso. Na terminologia de CHIOVENDA, assim, o conteúdo mínimo da coisa julgada é a atribuição de um bem da vida, conceito que deve ser tratado em toda sua complexidade. Essa concepção, que se encontra nos fundamentos do processo civil moderno, penetra as mais importantes legislações disciplinaram a cosia julgada: é a idéia que vem expressa no $\S$ 322 da Zivilprozeßordnung alemã, segundo o qual a sentença só faz coisa julgada na medida em que decidir sobre a pretensão deduzida na demanda ou reconvenção ${ }^{179}$; no art. 2.909 do Código Civil italiano, que restringe à coisa julgada ao accertamento contido na sentença ${ }^{180}$; e no art. 468 de nosso Código de Processo Civil, que vincula a coisa julgada à decisão sobre a lide $e^{181}$.

\subsubsection{A natureza processual da coisa julgada}

Admitida a separação entre os planos do direito material e do direito processual, bem como a posição de instrumentalidade do processo frente à tutela do direito objetivo (teoria dualista da jurisdição), a próxima condicionante que está pressuposta na análise da disciplina da coisa julgada é a natureza processual do instituto. Vejamos o que se quer dizer com isto.

Ao longo do desenvolvimento doutrinário da teoria da coisa julgada no século passado, após a superação daquela primeira concepção do instituto como meio de prova, houve uma polarização acerca de sua natureza entre duas correntes de pensamento. Uma

\footnotetext{
${ }^{179} \mathrm{O}$ texto do $§ 322$ é o seguinte: "Urteile sind der Rechtskraft nur insoweit fähig, als über den durch die Klage oder durch die Widerklage erhobenen Anspruch entschieden ist.”. KLAUS REISCHL afirma, nesse sentido, que ao contrário do que se passava no direito comum, a coisa julgada não terá por objeto propriamente a relação jurídica, mas apenas a conseqüência jurídica (Rechtsfolge) afirmada pelo autor e veiculada pela pretensão: "Im Unterschied zur gemeinrechtlichen Anerkennung der Rechtsverletzung mu $\beta$ das über einen Anspruch ergehende Urteil die Festellung nicht auf das streitige Rechtverhaltnis erstrecken, sondern kann es bei der Frage bewenden lasse, ob die begehrte Rechtsfolge aus dem geschilderten Sachverhalt ableitet werden kann.“ (Der objektiven Grenzen der Rechtskraft im Zivilprozeß. Tubingen: Mohr Siebeck, 2002. p. 164).

${ }^{180}$ Referido dispositivo, que não por acaso está inserido no título dedicado à "tutela jurisdicional dos direitos" (Livro VI, Título IV do Código de 1942), diz o seguinte: "L'accertamento contenuto nella sentenza passata in giudicato fa stato a ogni effetto tra le parti, i loro eredi o aventi causa."

181“A sentença, que julgar total ou parcialmente a lide, tem força de lei nos limites da lide e das questões decididas"
} 
primeira corrente afirmava a natureza material da coisa julgada, identificando a autoridade do julgado com a própria sentença de mérito. Sob esse prisma, considerava-se a sentença exclusivamente como fato jurídico, de modo que a obrigatoriedade por ela gerada não tem qualquer justificação especial, na medida em que repousa nas mesmas bases dos fatos jurídicos em geral. A coisa julgada se identificaria, assim, com a própria sentença. A teoria material da coisa julgada se reflete em fórmulas que assimilam a coisa julgada à lei do caso concreto, e está na raiz da definição legal que o instituto encontra no direito italiano (onde é regulada, não por acaso, pelo Código Civil, em seu artigo 2.909). Seus defensores, ao longo do tempo, a defenderam com o argumento de que ela seria a única capaz de resolver no plano lógico o problema da sentença injusta (i.e., a sentença contrária à lei), na medida em que, constituindo a sentença a própria regra jurídica, ela sempre estaria de acordo com o direito.

Em oposição, a segunda corrente manifesta que a coisa julgada tem natureza processual, e consiste em um vínculo dirigido aos juízes, que ficam obrigados a respeitar o conteúdo do julgado anterior. Essa teoria não desconhece a sentença como ato jurídico, e tampouco a obrigatoriedade de seus efeitos no plano do direito substancial. Contudo, indo um pouco além, ela defende que há algo a mais que se agrega à sentença, no plano processual, com a finalidade de conferir estabilidade ao resultado do julgamento em futuros processos.

É necessário compreender as implicações dessa divergência doutrinária. Afirmar a natureza processual da coisa julgada significa, em primeiro lugar, reconhecer a autonomia do instituto em relação à sentença, uma decorrência da própria autonomia do processo civil $^{182}$. Contudo, se a autonomia da ação em face do direito postulado em juízo foi logo afirmada pela ciência do processo, a autonomia da coisa julgada diante dos efeitos materiais da sentença foi um desenvolvimento doutrinário que exigiu mais tempo e maiores esforços, muito possivelmente pela força das concepções em torno do assunto transmitidas até nossos dias pela tradição jurídica. Este primeiro aspecto é de interesse

\footnotetext{
${ }^{182}$ A relação é estabelecida por WALTER PIVA RODRIGUES, segundo quem "as idéias dos defensores da teoria processual refletem a posição de autonomia da ciência do direito processual sobre a qual, na época, tanto se reivindicava" (Coisa julgada tributária, cit., p. 73). No mesmo sentido, CELSO NEVES afirma que a divisão de opiniões acerca da natureza da coisa julgada "coincide, de certo modo, com a cisão conceitual entre direito e ação, originada das modernas teorias construídas ao sabor dos ensinamentos de BULOW, WACH, DEGENKOLB e PLOTZ, através da qual se demonstrou a autonomia do direito de ação, em face do direito material que, através dela, é tutelado" (Contribuição ao estudo da coisa julgada civil, cit., p. 434).
} 
principalmente teórico, mas dele derivam as mais diversas conseqüências de natureza prática.

Em segundo lugar, ao se conceber a coisa julgada como um instituto de direito processual e não de direito material, resulta a consequiência de que os vínculos dirigidos ao juiz se traduzem em regras de procedimento que permitem abreviar o curso do processo, seja na reiteração da mesma demanda já julgada, seja no seu exame como questão de que dependa a resolução de uma pretensão distinta. Além disso, eventual violação à coisa julgada, nesse contexto, representa nulidade processual, e não apenas erro de julgamento. Constituindo o respeito ao julgado anterior pressuposto formal de validade da sentença, tem-se assim um grau mais intenso de proteção à estabilidade dos julgamentos.

Em terceiro lugar, reconhecer a natureza processual da coisa julgada representa também condicionar a estabilidade da sentença à garantia do devido processo legal, restringindo a sua imutabilidade e indiscutibilidade àqueles que tiveram oportunidade de debater em juízo a respeito do bem controvertido. Como anota JAMES GoldSCHMit, a identificação da coisa julgada com a sentença, própria da teoria materialística, é incompatível com a limitação subjetiva da coisa julgada, porque a sentença vale e deve ser reconhecida por todos ${ }^{183}$. De outro lado, a opção doutrinária pela teoria processual, que está na base da separação entre os efeitos da sentença e a autoridade da coisa julgada, proporciona o efeito de assegurar a terceiros, indiretamente interessados no objeto do juízo, a oportunidade de demonstrar o equívoco da sentença e resguardarem seus próprios interesses. Essa foi, precisamente, a grande contribuição de LIEBMAN para o processo civil: a salvaguarda dos interesses dos terceiros que não participaram da relação processual que lhes causou prejuízo.

A última conseqüência da natureza pública da coisa julgada, que a vê como vínculo que o Estado impõe a seus juízes, está em que as partes não podem renunciar à coisa julgada. Embora possam elas renunciar aos efeitos materiais da sentença a qualquer tempo, transacionando sobre as obrigações que deles decorram, não lhes é dado pedir do Estado um novo julgamento da causa, mesmo que nenhuma delas tenha ficado satisfeita com a decisão transitada em julgado e que se manifestem de comum acordo a respeito desse

\footnotetext{
${ }^{183}$ GOLDSHMIDT, James. Derecho procesal civil. Trad. de Leonardo Pietro Castro. Barcelona: Editorial Labor, 1936. p. 386 e ss. Também ENRICO ALLORIO, que é defensor da corrente materialística, afirma a impossibilidade da limitação subjetiva da coisa julgada, o que seria indesejável e supérfluo, tendo em vista o perfil bilateral da relação jurídica deduzida em juízo (La cosa giudicata rispetto ai terzi. Ristampa. Milano: Giuffré, 1992. p. 49-54). Não por acaso, tal como o havia feito PAGENSTECHER ao elaborar sua teoria, ALLORIO recorre à figura da relatividade do vínculo contratual para justificar esse posicionamento.
} 
pedido $^{184}$. Além disso, ela não protege apenas o vencedor do processo, mas também o vencido, que pode invocar sua autoridade em uma segunda demanda em que se busque acrescer novas vantagens à pretensão já reconhecida no primeiro processo ${ }^{185}$.

Cabe aqui fazer o registro de que, muito embora predomine no estudo da coisa julgada o delineamento que lhe confere a teoria processual, verifica-se em grande parte da doutrina uma tendência de não tomar partido expresso por qualquer dos lados dessa polêmica. Não que ela não tenha importância: a relação direta entre as modernas teorias unitárias do ordenamento jurídico e a teoria material da coisa julgada insere a questão entre os temas fundamentais do processo ${ }^{186}$, a ponto de LIEBMAN ter afirmado que a polêmica em torno das duas concepções sobre a coisa julgada é uma questão má colocada, que na realidade remete à "questão mais geral da posição e da destinação do processo em face da lei e do ordenamento jurídico"187. Afirma ele então que a coisa julgada não é "nem material e nem processual", na tentativa de evitar um debate que já se mostrava estéril pela irredutibilidade das posições opostas ${ }^{188}$, muito embora - e isto é afirmação nossa - a própria cisão que ele traça entre a eficácia da sentença (plano material) e a sua estabilidade (plano processual) permite incluí-lo entre os defensores da teoria processualística ${ }^{189}$. No

${ }^{184}$ Nesse sentido: LIEBMAN, Enrico Tullio. Manuale di diritto processuale civile. 4. ed. Milano: Giuffrè, 1984. v. 2, p. 420; CHIOVENDA, Giuseppe. Instituições de direito processual civil. 3. ed. Trad. J. Guimarães Menegale. São Paulo: Saraiva, 1969. v. 1, p. 383.

185،Ainda esse princípio depende na natureza pública do processo. A exceção de coisa julgada não corresponde a uma ou outra parte, conforme tenha ou não vencido (secundum eventum litis): mesmo à parte vencida é lícito opô-la. Por exemplo, o autor, vencedor num primeiro processo, repropõe a demanda com modificações vantajosas para ele: o réu excepcionará a coisa julgada." (CHIOVENDA, Giuseppe. Instituições de direito processual civil, cit., v. 1, p. 383-384).

${ }^{186}$ Nesse sentido: ALLORIO, Enrico. La cosa giudicata rispetto ai terzi, cit., p. 10; DINAMARCO, Cândido Rangel. Direito e processo, cit., p. 87.

${ }^{187}$ LIEBMAN, Enrico Tullio. Eficácia e autoridade da sentença. Tradução de Alfredo Buzaid e Benvindo Aires, com notas de Ada Pellegrini Grinover. In: Eficácia e autoridade da sentença e outros escritos sobre a coisa julgada. Tradução de Alfredo Buzaid e Benvindo Aires, com notas de Ada Pellegrini Grinover. 4. ed. Rio de Janeiro: Forense, 2007. p. 44. Também SÉRGIO MENCHINI considera que a polêmica em torno do caráter material ou processual da coisa julgada é "pouco profícua", afirmando que a adesão a uma tese ou outra tem valor puramente teórico e não influencia os problemas de caráter aplicativo da coisa julgada (Il giudicato civile, cit., p. 44-45).

${ }^{188}$ A postura de LIEBMAN ao evitar essa questão, contudo, não deixou de ser criticada. ENRICO ALLORIO, por exemplo, mesmo reconhecendo ser digna de meditação a proposta de se pensar na coisa julgada como estabilidade dos efeitos da sentença, em lugar de seus próprios efeitos, afirma ser incompleta a teoria, porque isso não elimina o problema de se definir a sua natureza (La cosa giudicata rispetto ai terzi, cit., p. 38). Entre nós, CELSO NEVES critica a postura por entender que a tomada de posição a respeito é necessária para que se estabeleçam os fundamentos para a resolução dos problemas práticos associados ao instituto; assim, "embora Liebman critique a preocupação da doutrina alemã em determinar a ubiquação dos efeitos da sentença, já hoje não é possível desconhecer a importância que tem o assunto, para a elaboração sistemática da doutrina da coisa julgada, num quadro maior da teoria do processo" (Contribuição ao estudo da coisa julgada civil, cit., p. 437).

${ }^{189}$ Isso se diz embora LIEBMAN não se tenha comprometido em nenhum momento com essa afirmação. Pelo contrário, na última edição de seu Manuale di diritto processuale civile, de 1984, (v. 2, p. 425-426) ele reitera o posicionamento manifestado quarenta e nove anos antes em Efficacia e autorità della sentenza. 
entanto, sem querermos cair na mesma armadilha de nos enredarmos em discussões teóricas e perdermos de vista as aplicações práticas que elas tornam possíveis, o que nos parece importante reter dessas teorias atualmente é o fato de que se a separação entre os planos do direito material e a do direito processual não for tão clara, tampouco se conseguirá distinguir a eficácia da sentença, como ato jurídico, da estabilidade que o sistema processual atribui ao seu conteúdo decisório. De outro lado, se for reconhecida a diferença entre os planos do direito material e do direito processual, bem como a posição instrumental do processo para a aplicação da lei, será possível vislumbrar a nítida distinção entre a eficácia da sentença (que opera no plano material) e os vínculos gerados pela coisa julgada (estes limitados ao plano processual) ${ }^{190}$, com as aplicações que acabamos de repassar neste item. Se nessa distinção parece haver um grau de abstração relativamente alto, as ricas aplicações práticas da teoria, em tema de limitação objetiva e subjetiva do julgado, muito simplificam a sua compreensão.

\subsubsection{A finalidade prática do instituto no direito moderno}

A quarta condicionante da teoria da coisa julgada, também decorrente dos escopos da jurisdição no moderno Estado de Direito, é a sua finalidade prática, voltada à estabilização da decisão que foi alcançada acerca do mérito do caso julgado. E embora essa vocação prática seja reconhecida praticamente pela unanimidade da doutrina, o que é realmente notável, dadas as divergências que cercam o assunto da coisa julgada, ela tem desdobramentos importantes que nem sempre são apreendidos com a mesma clareza.

Em primeiro lugar, a doutrina freqüentemente fala em finalidade prática da coisa julgada para remeter à questão dos fundamentos políticos da coisa julgada. À estabilidade do julgado se reconhece uma grande conveniência social, na função de proporcionar

Em sentido idêntico ao de nossa avaliação, porém, a opinião de ANDRÉ NEKATSCHALOW, $A$ coisa julgada nas relações continuativas. 1995. Dissertação (Mestrado) - Faculdade de Direito da Universidade de São Paulo, São Paulo, 1995. p. 64.

190“'A coisa julgada é, pois, um fenômeno de natureza processual, com eficácia restrita, portanto, ao plano processual, sem elementos de natureza material na sua configuração, teleologicamente destinada à eliminação da incerteza subjetiva que a pretensão resistida opera na relação jurídica sobre que versa o conflito de interesses. Como dado pré-processual de caráter subjetivo, essa incerteza não afeta a essência da relação jurídica controvertida, de caráter objetivo. A ela, simplesmente, se relaciona, porque nela está o objeto do juízo das partes. Assim também a coisa julgada que apenas se relaciona à res in iudicium deducta por constituir esta o objeto do juízo estatal" (NEVES, Celso. Contribuição ao estudo da coisa julgada civil, cit., p. 442). 
segurança àquele a qual o Estado reconhece a razão ao fim do processo, bem como na de impor a pacificação do conflito pela proibição de que se eternize a discussão em torno das causas já julgadas e decididas. A isso se pode somar ainda economia dos recursos do aparato judiciário, cujo eficiente dispêndio não se compatibilizaria com a possibilidade de reiterada renovação dos pedidos de tutela àquele direito afirmado e negado ao fim do processo. Assim, se fala em função prática da coisa julgada em sentido teleológico, para remeter ao objetivo de segurança das relações jurídicas e sociais, para o qual foi concebido o instituto.

Uma importante discussão, a propósito da fundamentação política da coisa julgada, diz respeito à sua essencialidade para a caracterização da jurisdição civil. Nesse sentido, é conhecida a posição de CHIOVENDA, que a partir do exemplo de sociedade nórdica primitiva (em nada equiparável ao Estado moderno), deduz a assertiva de que a coisa julgada não é algo de essencial ao conceito de jurisdição, mas sim algo que a ela se agrega por motivos da mais pura conveniência social com a finalidade de proporcionar estabilidade ao bem da vida reconhecido em juízo ${ }^{191}$. E em extremo oposto se encontra a posição do uruguaio EDUARDO COUTURE, para quem a coisa julgada é a pedra-de-toque que individualiza a jurisdição e a distingue de outras funções do Estado, como a administração $^{192}$. Na realidade, e como vimos há pouco, o conceito de jurisdição em si mesmo não é unívoco, pois ele varia de maneira significativa de acordo com a organização política de cada sociedade. Dessa forma, a complexidade das sociedades modernas aponta para a necessidade de que o exercício do poder jurisdicional se encerre em algum momento, pelo o mecanismo de imunização da decisão, que é uma condição de sua própria aceitabilidade pelas partes. No plano do direito, essa necessidade política se traduz nas garantias constitucionais da segurança, da proteção à confiança, e mais especificamente da

\footnotetext{
191،Sono raggioni di opportunità, riguardi d'utilità sociale, che fanno porre un termine alla indagine giudiziaria, e trattare la sentenza come legge irrevocabile pel caso concreto. È importante non dimenticare mais questa semplice considerazione: la veritá della quale può confermarsi con recentissimi studi su diritti antichi, che ci rivelano, ad esempio nelle origini del diritto norvegese, completamente ignorato il principio della cosa giudicata: esecutiva la sentenza, ma sempre aperta la discussione sulla sua esatezza, or in base a nuove prove, o no". (CHIOVENDA, Giuseppe. Sulla cosa giudicata. In: SAGGI di diritto processuale civile. Milano: Giuffrè, 1993, v. 2, p. p. 400).

${ }^{192}$ A lição do processualista uruguaio é precisamente a de que a coisa julgada integra a essência da jurisdição: "la cosa juzgada pertenece a la esencia de la jurisdicción. Si el acto no adquiere real o eventualmente autoridad de cosa juzgada, no es jurisdiccional. Si un acto adquiere autoridad de cosa juzgada es jurisdiccional. No hay jurisdicción sin autoridad de cosa juzgada (...) la cosa juzgada es, en este orden de elementos, la piedra de toque del acto jurisdiccional" (Fundamentos del derecho procesal civil, cit., p. 30 e 36). Entretanto, dentro da perspectiva instrumental que caracteriza sua obra, COUTURE pontua que a estabilidade não consiste em fim da jurisdição, mas um meio para necessário ao seu exercício, definida ela como "función pública, realizada por órganos competentes del Estado, con las formas requeridas por la ley, en virtud de la cual, por ato de juicio, se determina el derecho de las partes, con el objeto de dirimir sus conflictos y controversias de relevancia jurídica, mediante decisiones con autoridad de cosa juzgada, eventualmente factibles de ejecución". (Fundamentos del derecho procesal civil, cit., p. 34).
} 
intangibilidade da coisa julgada. Isto faz com que esse instituto conte com elevada envergadura constitucional na maioria dos ordenamentos ocidentais ${ }^{193}$. Entretanto, ele não parece ser um elemento nuclear, mas antes acidental, para a caracterização da jurisdição, de modo que a lei pode flexibilizar a sua incidência com prazos mais ou menos curtos para a eventual desconstituição da decisão de mérito, ou mesmo permitir que em determinados casos, como ocorre no processo coletivo, seja facultada a reapreciação da causa mediante nova prova.

Em segundo lugar, atribuir à res judicata finalidades práticas significou limitar o objetivo da coisa julgada à tarefa mais simples de assegurar o resultado da decisão judicial, ainda que isso se faça à custa de incoerências com os argumentos ou a verdade dos fatos discutidos no processo em que a decisão se formou, ou com o que a respeito deles se decidiu em outro processo. A coisa julgada, nesse sentido, tem a função de evitar conflitos práticos entre julgados, isto é, decisões conflitantes sobre um mesmo bem da vida; sendo a ela indiferentes os eventuais conflitos lógicos entre a motivação, ou a entre a apreciação de fatos, em processos sucessivos ${ }^{194}$. Nessa diretriz encontra-se implícito o reconhecimento de que o processo civil moderno não tem a pretensão de atingir uma verdade, ou uma coerência absoluta entre a decisão judicial e seus fundamentos, como a fragmentação normativa do período do direito comum medieval impunha à legitimação das decisões. A dialética processual atual tem outros escopos: ela deseja pacificar o conflito por meio da aplicação do direito considerado como válido pelo Estado, por meio de um procedimento de formas delimitadas, que busca conciliar objetivos em conflito como a segurança jurídica e a celeridade. No balanceamento dessas necessidades, há de se admitir que o erro é uma possibilidade sempre presente na jurisdição civil (muito embora caiba à técnica processual

\footnotetext{
${ }^{193}$ Em pesquisa detalhada sobre o tema no direito processual civil brasileiro, LUIZ GUILHERME PENNACCHI DELLORE analisou oito espécies de sentenças que não fariam coisa julgada, em alguns casos até mesmo segundo a redação da lei, para chegar à conclusão de que: "não é possível falar em um sistema de sentenças que não são cobertas pela coisa julgada. Ao contrário, é possível reforçar o conceito e sistematização do próprio instituto a partir dos dispositivos que supostamente impedem que a sentença seja coberta pela res judicata, sempre tendo em mente a tríplice identidade." (Das sentenças que não são cobertas pela coisa julgada no direito processual civil brasileiro. 2006. Dissertação (Mestrado). Faculdade de Direito da Universidade de São Paulo, São Paulo, 2006.

${ }^{194}$ Nesse sentido é que se coloca a clássica lição de CHIOVENDA: "Os princípios da coisa julgada excluem, por conseqüência, por si mesmos, apenas o conflito prático dos julgados, isto é, decisões diversas relativamente à própria ação, portanto praticamente incompatíveis. Não visam eles, porém, nem prescrevem nenhum remédio ao simples conflito teórico dos julgados, quer dizer, ao caso de decisões logicamente incompatíveis, mas praticamente conciliáveis" (CHIOVENDA, Giuseppe. Instituições de direito processual civil, cit., v. 1, p. 412-413). Atente-se para a posição concretista do autor, contudo, que o faz definir o conflito prático como julgados incompatíveis sobre a mesma ação; se quisermos adequar o trecho à teoria abstrata que prevalece atualmente na doutrina, melhor seria falar em incompatibilidade julgados sobre a mesma demanda ou, melhor ainda, sobre a mesma pretensão processual.
} 
elaborar formas que confinem esse risco dentro de limites aceitáveis). É ilustrativa a metáfora de CARNELUTTI, para quem a verdade da sentença é um amálgama de erro e verdade a que se empresta curso legal por uma convenção social, de maneira similar à liga metálica da moeda, que circula como ouro embora não seja feita desse material ${ }^{195}$. A essa finalidade se proporcionar segurança, independentemente do erro ou acerto da sentença, se presta a coisa julgada.

Nesse sentido, quando CHIOvEnDA enfatizava a finalidade prática da coisa julgada no início do século XX, suas palavras tinham um grande propósito crítico ao método dialético-tópico do processo germânico medieval (enaltecido à época pela doutrina da Escola Histórica de SAVIGNY, p. ex.), caracterizado por uma excessiva preocupação com fundamentação lógica da decisão, aspecto indissociável da pluralidade normativa - e, portanto, da ausência de referenciais vinculantes para a decisão do juiz - que caracterizou o período medieval. A unificação do direito sob o monopólio do Estado, bem como a idéia de primado da lei produzida pelos parlamentos, reduziu a necessidade de justificação lógica das decisões judiciais, na medida em que elas passaram a ter apoio na lei positiva, a cuja aplicação a jurisdição do Estado moderno passou a estar funcionalizada. Essa evolução conduziu a que se passasse a distinguir, no processo e nas decisões judiciais, entre os seus elementos lógicos e o seu elemento decisório. Reduzida a complexidade lógica da atividade jurisdicional, o que se passou a destacar nela foi o seu aspecto decisório e sua imperatividade, diretamente associadas à autoridade estatal. Consoante assinala ALFREDO ROCCO ${ }^{196}$, a finalidade do processo passou a ser a de eliminar a incerteza da norma jurídica aplicável a um caso concreto.

\footnotetext{
195“Corre tra quello che il giudicato à e quello che dovrebbe essere la stessa differenza che tra l'oro puro e l'oro monetato. Il giudicato, come una moneta aurea, non è oro di ventiquattro carati; si trata di una lega, in cui la verità è amalgamata con l'errore. La verità formale non è un'altra verità; piuttosto è meno verità, un grado di veritá inferiore alla verità pura. Peraltro questa verità scadente ha un corso legale del tutto analogo a quello della moneta: se non è veritá, vale come se fosse verità: res iudicata pro veritate habetur non vuol dire soltanto che non è verità ma che vale come verità." (Diritto e processo. Napoli: Morano, 1958; p. 266, grifos nossos).

196، (...) la sentencia es el acto del juez encaminado a eliminar la incertitumbre sobre la norma aplicable al caso concreto, acreditando una relación jurídica incierta concreta" (ROCCO, Alfredo. La sentencia civil. Trad. de Mariano Ovejero. Buenos Aires: Libreria El Foro, 2003. p. 107).
} 


\subsection{Conceito de coisa julgada}

\subsubsection{Distinções necessárias: trânsito em julgado, coisa julgada formal e coisa julgada material}

Em nossa primeira aproximação da definição do conceito de coisa julgada, após a exposição das condicionantes institucionais do instituto, trataremos de distinguir da coisa julgada conceitos afins. Com isso, esperamos obter um primeiro recorte mais grosseiro do objeto de nosso estudo, para em seguida lapidá-lo com a análise detalhada de cada uma de suas características. Mas nessa primeira depuração, cuidaremos de dizer aquilo que não é a coisa julgada.

O primeiro dos conceitos a distinguir é o de trânsito em julgado. Pensamos que a menção expressa se faz oportuna diante do fato de que, ocasionalmente, a expressão se vê utilizada como sinônima de coisa julgada, e em alguns casos chega a ser confundida com ela: assim, por exemplo, o conhecido erro de definição constante do Dec.-Lei $n^{\circ}$ 4.657/42, a Lei de Introdução às Normas do Direito Brasileiro (antiga Lei de Introdução ao Código Civil), que chama "coisa julgada ou caso julgado a decisão judicial de que já não caiba recurso" ${ }^{197}$. Também se encontram manifestações de doutrina e jurisprudência que, desejando apontar a não formação da coisa julgada, manifestam que determinado tipo de sentença não transita em julgado ${ }^{198}$. Na verdade, "trânsito em julgado" e "coisa julgada"

\footnotetext{
${ }^{197}$ Em ensaio publicado originalmente em 1970 (antes do atual Código de Processo Civil, que foi mais cuidadoso na definição do instituto), BARBOSA MOREIRA dirigia a seguinte crítica à definição da lei introdutiva: "a expressão, demasiado simplificadora, permite-nos saber quando começa a existir a coisa julgada; nada nos informa, porém, sobre a essência do fenômeno e sobre o modo como ele atua para desempenhar sua função específica. Detém-se a regra legal no aspecto cronológico e deixa totalmente na sombra o aspecto ontológico da coisa julgada" (Ainda e sempre a coisa julgada, cit., p. 136). E ainda antes, em 1936, GUILHERME ESTELLITA dizia a respeito que "na cousa julgada o que sobreleva a tudo mais e lhe constitue a essência mesma, é a autoridade, é a força, é a eficácia atribuída à decisão judicial. A inadmissão de recursos é apenas um requisito à aquisição daquelle poder" (Da cousa julgada: fundamento político e extensão a terceiros. Tese. Rio de Janeiro, 1936. p. 9).

${ }^{198}$ Assim, por exemplo, AMERICANO, Jorge. Processo civil e commercial no direito brasileiro: phases probatória, decisória e executória. São Paulo: Livraria Acadêmica Saraiva, 1925. p. 217. Mais recentemente, querendo claramente se referir à formação de coisa julgada, lê-se da monografia de TERESA WAMBIER e JOSÉ MIGUEL MEDINA que "há certas sentenças, e há muito que um dos autores deste ensaio vem defendendo este ponto de vista, que não têm aptidão para transitar em julgado" ( $O$ dogma da coisa julgada: hipóteses de relativização. São Paulo: Ed. Revista dos Tribunais, 2003. p. 26), em confusão que se repete por diversas oportunidades no mesmo trabalho; no Manual de LUIZ GUILHERME MARINONI e SÉRGIO ARENHARDT, por fim, se lê que “(...) se a coisa julgada representa a imutabilidade decorrente da formação da lei do caso concreto, se ela representa a certificação dada pela jurisdição a respeito da pretensão de direito material exposta pelo autor, somente isto é que pode transitar em julgado" (Manual do processo de conhecimento. 5. ed. São Paulo: Ed. Revista dos Tribunais, 2006. p. 633). A confusão entre os conceitos, como se vê, é recorrente.
} 
são coisas muito diversas: o primeiro consiste no fato jurídico da preclusão dos recursos cabíveis contra a sentença, enquanto a coisa julgada consiste na autoridade ${ }^{199}$ - i.e., no vínculo jurídico - que torna imutável e indiscutível o comando contido na sentença de mérito, a partir do momento em que ela se torne definitiva (art. 467, CPC). O trânsito em julgado é pressuposto da formação da coisa julgada, mas a coisa julgada é algo a mais, que se agrega apenas às sentenças de mérito. Enquanto todas as sentenças transitam em julgado, apenas algumas adquirem a estabilidade própria à res judicata. Em outras palavras, a coisa julgada é um efeito do trânsito em julgado das sentenças de mérito, o que indica a relação, mas não a confusão entre as duas coisas.

O segundo instituto que queremos excluir do objeto de nossa pesquisa é a chamada coisa julgada formal. A coisa julgada formal opera no âmbito interno ao processo, e consiste na irretratabilidade da sentença por parte do juiz (artigos 463 e 471 do Código de Processo Civil) ${ }^{200}$. A imutabilidade das sentenças dentro do próprio processo em que ela foi dada é uma exigência prática para que se assegure que o processo chegue a um fim, razão apela qual a coisa julgada formal é atributo de todas as sentenças (e não apenas das de mérito). Por isso, se pode dizer que a coisa julgada formal é pressuposto da coisa julgada. À coisa julgada formal se reconhece ainda o efeito sanatório geral de nulidades ${ }^{201}$, que a diferencia da mera preclusão e pode ser visto como uma espécie de projeção interna da eficácia preclusiva da coisa julgada material, restrita às questões de procedimento. Consiste ele em que eventuais irregularidades formais nos atos do processo, mesmo

${ }^{199}$ O uso da expressão "autoridade" para designar a indiscutibilidade da sentença é de Liebman. Embora tenha sido objeto da crítica candente de CARNELUTTI (Efficacia, autorità e immutabilità dela sentenza. In: Studi di processo civile. Padova: Cedam, 1939; Bilancio di uma polemica. In: Studi di processo civile, cit.), o termo se popularizou com o sentido aqui apresentado, razão pela qual dele nos valemos ao longo desta dissertação.

${ }^{200}$ Conforme a lição de LIEBMAN, "indica, pois, a coisa julgada formal a imutabilidade da sentença como ato processual" (Eficácia e autoridade da sentença, cit., p. 55).

${ }^{201}$ SERGIO MENCHINI descreve a eficácia sanatória geral da seguinte maneira: “(...) quando la pronuncia abbia raggiunto la condizione prevista dall'art. 324 c.p.c., per mancato o infrutuoso esercizio del potere di impugnazione, i vizi della stessa, sia processuali sia di giudizio, sono considerati dall'ordinamento tamquam non essent. Il passagio in giudicato formale sana gli eventuali difetti del provvedimento giurisdizionale e rende (relativamente) estabile l'accertamento della volontà concreta di legge sostanziale in esso contenuto". (Il giudicato civile, cit., p. 30). Nesse sentido é que DANIEL AMORIM ASSUMPÇÃO NEVES, criticando posições doutrinárias que identificam preclusão com a coisa julgada formal, afirma a autonomia desta última pela circunstância de que ela encobre mesmo questões de ordem pública, insuscetíveis de preclusão. "No caso do processo chegar a seu final por meio de sentença terminativa, essas matérias, embora não tenham sofrido o efeito da preclusão, certamente não poderão mais ser rediscutidas, de forma a ser claramente outro instituto que impede a apreciação por parte do juiz. Esse instituto é justamente a coisa julgada formal, que impede a discussão de qualquer matéria - inclusive as que não são sujeitas a preclusão - dentro daquela relação jurídica processual, que inclusive chegou a seu fim em razão da sentença" (Preclusões para o juiz: preclusão pro judicato e preclusão judicial no processo civil. São Paulo: Método, 2004. p. 54). 
quando tenham por objeto matéria de ordem pública, sejam absorvidas pela sentença e não possam ser invocadas após o seu trânsito em julgado.

Dessa forma, quando falamos de coisa julgada não queremos remeter nem ao trânsito em julgado e nem à coisa julgada formal, institutos esses que, embora sejam afins e constituam seus pressupostos, não se confundem com o objeto de nosso estudo. Por coisa julgada, de maneira elíptica, queremos nos referir sim à coisa julgada material, isto é, os vínculos gerados pelo julgado de mérito que operam no âmbito externo ao processo em que foi dada a sentença.

\subsubsection{O desenvolvimento da doutrina em torno da natureza da coisa julgada}

Ao proferir, no início do século XX, uma conferência ${ }^{202}$ de propósito crítico à teoria da coisa julgada como ficção de verdade, GIUSEPPE CHIOVENDA iniciava suas palavras com a afirmação - que viria a se tornar célebre - de que muito pouco restava a dizer a respeito desse instituto que não fosse inútil, quando a doutrina àquela altura já havia amadurecido as concepções modernas do processo e surgiam as primeiras legislações que incorporavam os correspondentes princípios. No entanto, não se pode ignorar que àquela altura o debate sobre a natureza da coisa julgada estava em seu auge (basta tomar em consideração que a teoria da coisa julgada como presunção de verdade, desenvolvida a partir das premissas da Escola Histórica, havia, apenas alguns anos antes, encontrado a acolhida da comissão que elaborou o influente Código Napoleônico), de modo que aquilo parece ter sido dito muito mais com propósito retórico do que propriamente analítico.

E assim se percebe com naturalidade que os posteriores desenvolvimentos da doutrina vieram a demonstrar que a frase estava duplamente equivocada ${ }^{203}$ : nem os valores políticos que CHIOvenda dizia consolidados haviam se assentado em bases absolutamente firmes para os anos seguintes, e nem o trabalho doutrinário sobre o instituto era obra acabada, na medida em que suas idéias foram objeto de significativos aperfeiçoamentos. $\mathrm{O}$

\footnotetext{
${ }^{202}$ Essa conferência, proferida em Napoli no ano de 1905, foi publicada nos ensaios reunidos do autor sob o título de "Sobre a coisa julgada" (CHIOVENDA, Giuseppe. Sulla cosa giudicata, cit., v. 2, p.399-409).

${ }^{203}$ Refletindo sobre essa conhecida frase anos depois, BARBOSA MOREIRA viria a dizer que “(...) poucos temas jurídicos têm merecido dos estudiosos atenção maior que o da coisa julgada. Quem se detiver, porém, no exame do material acumulado, chegará à paradoxal conclusão de que os problemas crescem de vulto na mesma proporção em que os juristas se afadigam na procura de soluções" (Ainda e sempre a coisa julgada, cit., p. 133).
} 
vaticínio certamente indicava uma direção a ser seguida, porém, e o que se pode afirmar com segurança ao fazermos um balanço da doutrina produzida no último século é que, da mesma forma como ocorreu com outros institutos como a ação e a prova, a teoria da coisa julgada se desenvolveu no sentido de uma crescente publicização do conceito, ou seja, de uma progressiva migração de seu estudo do plano do direito civil em direção ao direito processual, com a identificação de perfis próprios ao instituto. Não foi sem resistências, no entanto, que se chegou a esse resultado.

Quando do início do estudo sistemático da ciência processual, no século XIX, ainda se fazia muito presente a força do elemento lógico na formação dos julgados, um traço do caráter dialético e problemático do iudicium medieval, em sua preocupação legitimadora de se aproximar da verdade por meio da argumentação. Confiante da capacidade do processo em atingir essa finalidade, se dizia da coisa julgada - na conhecida e exagerada expressão utilizada por SIGISMONDO SCACCIA - que ela era capaz de "fazer do branco, negro, originar e criar as coisas, transformar o quadrado em redondo, alterar os laços de sangue e converter o falso em verdadeiro"204. Seguindo essa influência, o alemão FRIEDRICH KARL VON SAVIGNY, que foi o maior expoente da Escola Histórica do direito e um admirador do caráter fluído e adaptável do direito comum medieval, viria a elaborar em seu Sistema do Direito Romano Atual (1840) a teoria da coisa julgada como ficção de verdade (Fiktion der Warheit), incluindo o instituto entre os meios de prova. Destinado o julgado a fazer prova das relações jurídicas, nessa teoria os elementos do raciocínio do juiz também adquirem acentuada relevância, razão pela qual SAVIGNY defendia que não apenas a decisão, mas também seus "motivos objetivos" deveriam fazer a mesma prova que o resultado do julgamento. Essa concepção haveria de se difundir entre os civilistas, entre eles POTHIER, cujo tratado de direito civil viria a ter marcada influência sobre a comissão presidida por PORTALIS - que elaborou o projeto do Código Napoleônico ${ }^{205}$. A teoria do tratadista francês consistia em uma derivação da teoria da ficção de verdade, e encarava a coisa julgada como uma presunção. No Brasil, em fins do século XIX e início do século passado, essa linha de pensamento contou com a acolhida de PAULA BATISTA e de

\footnotetext{
${ }^{204}$ apud ESTELLITA, Guilherme. Da cousa julgada: fundamento político e extensão a terceiros, cit., p. 26. Acrescenta este último o papel do supremo tribunal eclesiástico na difusão dos exageros dessa teoria, dada a larga influência do Direito Canônico naquele ambiente de fragmentação política. No mesmo sentido, CHIOVENDA, Giuseppe. Cosa giudicata e preclusione, cit., v. 3, p. 256 e ss.

${ }^{205} \mathrm{O}$ artigo 1305 do Código Civil francês viria, dessa forma, a incluir a coisa julgada entre as presunções de direito: "La présomption légale est celle qui est attachée par une loi spéciale à certains actes ou à certains faits ; tels sont: (...) $3^{\circ}$ L'autorité que la loi attribue à la chose jugée".
} 
AURELIANO GUSMÃO ${ }^{206}$, e veio por integrar nosso direito positivo por meio da regra do art. 185 do regulamento $\mathrm{n}^{\mathrm{o}} 737$, de $1850^{207}$.

A obra de GiUSEPPE CHIOvEndA, elaborada nos anos seguintes, viria a superar as teorias que definiam a coisa julgada como presunções ou ficções. Para ele, a coisa julgada tinha a função prática de tornar estável o resultado do processo, assegurando à parte vencedora a fruição do bem da vida, a cujo direito lhe houvesse sido reconhecido pela sentença de mérito ${ }^{208}$. E tampouco o processo tinha qualquer preocupação em atingir a verdade das coisas: tratava-se de uma função pública, pela qual o Estado exercia seu poder de império e buscava aplicar a vontade concreta da lei para solucionar os conflitos. Como nessa atividade sempre haveria a possibilidade do erro, os elementos lógicos que compõem o raciocínio do juiz, por regra, não deveriam adquirir qualquer relevância externa. Dada a irrelevância dos motivos, a coisa julgada não haveria de se preocupar com motivações conflitantes em processos distintos, sendo sua função apenas a de evitar que, incorrendo em conflito prático, dois julgados dispusessem de modo contrário sobre um mesmo bem da vida. Esses aspectos da teoria da coisa julgada, aceitos até os presentes dias, viriam a constituir o marco pelo qual se inicia a moderna compreensão do instituto.

Nos anos seguintes, o debate doutrinário viria a se encaminhar para a polêmica em torno da natureza material ou da natureza processual da coisa julgada, o que foi um reflexo da hesitação doutrinária em torno da autonomia do processo frente ao direito material. De fato, a teoria material foi inicialmente formulada por MAX PAGENSTECHER, que equiparava o processo a um contrato entre os litigantes (Feststellungsvertrag), e via na sentença uma fonte constitutiva do direito ${ }^{209}$. A coisa julgada se confundiria, assim, com a

\footnotetext{
206،As palavras cousa julgada indicão uma decisão, que não pende mais dos recursos ordinários; ou porque a lei não os concede (...); ou porque a parte não usou delles nos termos fataes e peremptórios da lei, ou porque já forão esgotados. O effeito d'uma tal decisão, é ser tida por verdade; assim, todas as nullidades e injustiças relativas, que porventura se comettessem contra o direito das partes, já não são susceptíveis de revogação" (PAULA BAPTISTA, Francisco de. Compendio de theoria e prática do processo civil comparado com o comercial e de hermenêutica jurídica. 4. ed. Rio de Janeiro: Garnier Editor, 1890. p. 426); no mesmo sentido, falando na "mais sublime das presunções legaes", AURELIANO DE GUSMÃO, Manoel. Cousa julgada. São Paulo: Duprat, 1914. p. 20 e ss.

${ }^{207} \mathrm{O}$ Regulamento 737 definia a coisa julgada como presunção absoluta, que não cedia nem mesmo à prova em sentido contrário. O texto da lei era o seguinte: "são presumpções legaes absolutas os factos, ou actos que a lei expressamente estabelece como verdade, ainda que haja prova em contrario, como - a cousa julgada".

208،(...) a coisa julgada não é senão o bem julgado, o bem reconhecido ou desconhecido pelo juiz" CHIOVENDA, Giuseppe. Instituições de direito processual civil, cit., v. 1, p. 369.

${ }^{209}$ PAGENSTECHER, Max. Zur lehre von der materiellen rechtkraft. Berlim: Franz Vahlen, 1904. Na crítica de JOSE IGNÀCIO BOTELHO DE MESQUITA, "Pagenstecher entreviu na sentença uma função constitutiva de direito comparável á de um contrato declaratório que, diferenciando a declaração judicial de um mero parecer, torná-la-ia obrigatória para o futuro"; entretanto, "a possibilidade de vir a sentença a declarar qualquer coisa falsa, que conduziu aqueles mestres a considerarem como verdade o conteúdo da
} 
nova e obrigatória situação criada pela sentença. Logo se percebe que, na raiz da teoria se encontra como pressuposto a equiparação do processo a uma categoria de direito civil, negando a autonomia da relação processual como ramo do direito público ${ }^{210}$, ou ao menos a sua capacidade de decidir de forma imperativa sobre a aplicação do direito. De uma maneira geral, para os seguidores dessa corrente, sempre se conceberá o processo como instrumento para a criação de novas situações substanciais, em contraste com a idéia de que a função da jurisdição é a aplicação da lei. A teoria materialística da coisa julgada contaria no futuro com destacados seguidores, como ENRICO ALLORIO, que se destacaria pela oposição a qualquer limitação da extensão do julgado a terceiros ${ }^{211}$, MARIO VELLANI $^{212}$ e REMO CAPONI ${ }^{213}$ em tempos mais recentes. No Brasil, a tese de RONALDO CUNHA CAMPOS pressupõe a teoria material ${ }^{214}$, e a ela se declara filiado ADROALDO FURTADO FABRÍCIO ${ }^{215}$.

sentença errônea, levou Pagenstecher a percorrer o caminho inverso, fazendo com que a sentença certa fosse equiparada à errada" (BOTELHO DE MESQUITA, José Ignácio. A autoridade da coisa julgada e a imutabilidade da motivação da sentença. In: ___. Teses, estudos e pareceres de processo civil: jurisdição e competência - sentença e coisa julgada - recursos e processos de competência originária dos tribunais. São Paulo: Ed. Revista dos Tribunais, 2005. v. 2, p. 107).

${ }^{210}$ Esse traço da teoria materialística da coisa julgada é bem evidente da construção e ENRICO ALLORIO, para quem o julgado constitui um novo fato jurídico cujo suporte fático ou confirma ou modifica a relação de direito material preexistente, na tentativa de superar o problema da sentença injusta. Assim, "l'efficacia di conferma della regola preesistente, che emana dalla sentenza giusta, configura precisamente una ipotesi di concorso di fattispecie", enquanto "la sentenza ingiusta ha, secondo la teoria sostanziale, efficacia costitutiva: vale a dire efficacia modificatrice dello stato di diritto preesistente" (La cosa giudicata rispetto ai terzi, cit., p. 24 e 27). A observação de ALLORIO parece muito pertinente no que diz respeito à eficácia da sentença, que de fato opera no plano material, como fato jurídico que é. Entretanto, nos parece, essas observações não são suficientes para justificarem a sua estabilidade.

${ }^{211}$ ALLORIO, Enrico. La cosa giudicata rispetto ai terzi, cit., p. 50 e ss.

${ }^{212}$ VELLANI, Mario. Naturaleza de la cosa juzgada. Traducción de Santiago Sentís Melendo. Buenos Aires: Edicciones Juridícas Europa-America, 1963. p. 124-125.

${ }^{213}$ CAPONI, Remo. L'efficacia del giudicato civile nel tempo. Milano: Giuffrè, 1991.

${ }^{214}$ Em seu Limites objetivos da coisa julgada (2. ed. Rio de Janeiro: Aide, 1988), RONALDO CUNHA CAMPOS constrói a teoria de que a decisão do mérito da lide deve se assentar na concatenação das eficácias das questões prejudiciais, que assim também se consideram decididas. Identifica assim a formação lógica da sentença com o direito externo ao processo, razão pela qual, ainda que não se declare o autor como partidário da teoria material, ele nos parece adotar seus postulados.

${ }^{215} \mathrm{Na}$ realidade, é com reticência que incluímos o autor como expoente da teoria material em nosso país. Pois embora ADROALDO FABRÍCIO se declare adepto dessa vertente, com o argumento de que a sentença assume a condição de lei do caso concreto, de maneira bastante contraditória ele defende a separação entre o instituto da coisa julgada e a teoria dos efeitos da sentença, chegando inclusive a criticar LIEBMAN por não ter levado a separação mais adiante (Ação declaratória incidental, cit., p. 52-53). Ora, essa separação conceitual é típica da teoria processual da coisa julgada e da visão dualista do ordenamento, traços que podem ser encontrados com toda clareza no pensamento do autor. Essa vacilação deriva, provavelmente, da dificuldade em delimitar os efeitos da sentença, que efetivamente operam no plano material (uma realidade que não é negada pela teoria processualística, muito antes pelo contrário), do juízo conclusivo de mérito que é objeto da coisa julgada e se circunscreve ao plano do processo. 
Pouco antes da obra de PAGENSTECHER, a doutrina germânica também havia desenvolvido a doutrina processualística da coisa julgada, buscando melhor definir os contornos do instituto de acordo com a premissa da autonomia do direito processual $^{216}$. Por essa vertente, obteve destaque a teoria de Hellwig, que definia a coisa julgada como a eficácia da declaração (Festellungswirkung) contida na sentença. E assim, na Alemanha, a doutrina - que "seguiu-lhe em peso"217 - tendeu a considerar que a coisa julgada se localizava sobre o elemento declaratório comum a todas as sentenças. Essa linha de pensamento que veio a encontrar ampla acolhida também na Itália, com ERNESTo HEINITZ ${ }^{218}$, na Espanha com JAIME GUASP ${ }^{219}$, e também entre diversos processualistas brasileiros, dentre os quais podem se citar GUILHERME Estellita $^{220}$, Pontes de Miranda ${ }^{221}$, Ovídio Baptista da Silva ${ }^{222}$, Celso Neves ${ }^{223}$,

${ }^{216}$ A esse respeito, GIOVANNI PUGLIESE sublinha que a autonomia do processo não se reflete apenas em uma precisa distinção e contraposição entre os institutos de direito material e de direito processual, mas também na atribuição a este último de institutos de ligação entre um e o outro, como a ação e a coisa julgada (Giudicato civile: diritto vigente. In: Enciclopedia del diritto. Milano: Giuffrè, 1969. v. 18, p. 791).

${ }^{217}$ LIEBMAN, Enrico Tullio. Eficácia e autoridade da sentença, cit., p. 21.

${ }^{218}$ HEINITZ, Ernesto. Limitti oggettivi della cosa giudicata. Padova: CEDAM, 1937. p. 101.

${ }^{219}$ GUASP, Jaime; ARAGONESES, Pedro. Derecho procesal civil: introducción y parte general. 7. ed. Cizur Menor (Navarra): Thompson-Civitas, 2005. t. 1, p. 587.

220، “....) o que predomina no conceito de coisa julgada é a idéia do poder atribuído à sentença no declarar a existência ou a inexistência da relação jurídica no processo agitada" (ESTELLITA, Guilherme. Da cousa julgada: fundamento político e extensão a terceiros, cit., p. 10).

${ }^{221}$ A respeito de PONTES DE MIRANDA, sua filiação à teoria da eficácia da declaração é devida em razão da definição que ele dá à coisa julgada, afirmando que "o que se há de entender por eficácia de coisa julgada material é a eficácia que o elemento declarativo da sentença produz, chamada força (se prepondera) ou efeito (se se junta à força da sentença). Consiste em vincular as partes à declaração." (Comentários ao Código de Processo Civil: arts 444 a 475. 3.ed. Rio de Janeiro: Forense, 1997. t. 5, p. 157). Contudo, há um aspecto importante em que sua teoria se aproxima da teoria material da coisa julgada: a concepção de que a coisa julgada se dirige às partes, em todas as circunstâncias da vida, e não apenas aos juízes de futuros processos. Assim, escreve ele: "a coisa julgada material produz-se como criação de indiscutibilidade entre as partes. Mas, ¿que é indiscutibilidade entre as partes? É o não mais poder ser, entre as pares, posta em dúvida questões, que foram julgadas no processo. Entre as partes e em quaisquer que sejam as circunstâncias, excetuado apenas o caso da lei nova que viesse a alcançar, no passado, a coisa julgada, portanto a sentença; a sentença, portanto a lei processual vigente ao tempo em que a sentença foi proferida. Em quaisquer circunstâncias, portanto também noutro processo. Quando os juristas definiam a coisa julgada como vínculo entre as partes para o juiz de futuro processo sobre o mesmo caso, não erravam; apenas a sua definição era, como se diz em Lógica, fraca, isto e, insuficiente; a coisa julgada também vincula as partes, para que a 'respeitem' mesmo outras pessoas que o juiz. Vincula as partes, eis tudo" (idem, p. 158-159). Essa aproximação da teoria material se dá de forma inconsciente, na medida em que ele se diz, e na maior parte do tempo se mostra coerente com essa opção, filiado à teoria processual (p. 109-110).

${ }^{222}$ Cabe desde já consignar a observação de que OVÍDIO BAPTISTA DA SILVA viria ainda a desenvolver de forma significativa seu pensamento a respeito do tema para passar a distinguir os conceitos de efeito declaratório - o juízo sobre o mérito contido na sentença - da eficácia declaratória que atua no plano do direito material, e situar apenas sobre o primeiro deles a estabilidade característica da coisa julgada (vide item. 2.3.2, infra).

${ }^{223}$ CELSO NEVES adere à teoria processual tal como classicamente foi formulada, afirmando que "a coisa julgada, essa é restrita ao processo de conhecimento e, pois, ao elemento declaratório da sentença, se objetivamente complexa" (Contribuição ao estudo da coisa julgada civil, cit., p. 468). Observe-se que nessa definição está presente a idéia de que todas as sentenças contêm um elemento declaratório, podendo eventualmente a ele se somar elementos declaratórios e constitutivos; a coisa julgada incide apenas sobre o 
Paulo Roberto de Oliveira Lima ${ }^{224}$, Marinoni-Arenhardt ${ }^{225}$ e SÉrgio Gilberto PORTO $^{226}$.

Na Itália, a corrente processualista viria ainda a ter desenvolvimentos importantes pelo trabalho de ENRICO TUlLIO LIEBMAN, aluno de CHIOvENDA que mais tarde imigraria para o Brasil, e que publicou em 1935 o ensaio "Eficácia e Autoridade da Sentença". Em seu trabalho, LIEBMAN buscou inicialmente diminuir a importância do debate instaurado entre a teoria material e a teoria processual da coisa julgada ("uma questão mal colocada"), embora se inclinasse implicitamente em direção à segunda, pela separação de conceitos que constitui o cerne de seu ensaio. Também dirigiu críticas à teoria de HellwiG, afirmando que a coisa julgada não se dirigia unicamente ao efeito declaratório das sentenças, antes se aplicando, igualmente, aos efeitos constitutivos e condenatórios ${ }^{227}$. E finalmente, formulou sua teoria, que se baseava na separação nítida entre a eficácia natural da sentença e sua autoridade de coisa julgada. A eficácia da sentença, entendida como aplicação da vontade concreta da lei ao caso decidido, tem a propriedade de subordinar imediatamente os interesses por força do império estatal. A autoridade da coisa julgada, de outro lado, consistiria em algo mais, externo à sentença e que foi disposto pelo legislador por motivos de conveniência social. Tratar-se-ia de uma qualidade que se agrega à sentença e, particularmente, a seus efeitos, tornando-os imutáveis e indiscutíveis. Entre a eficácia da sentença e a sua autoridade existiriam, na teoria de LIEBMAN, diferenças quanto à extensão. Os efeitos da sentença, por decorrerem de ato de império estatal ao exercer sua função jurisdicional, se estendem a todos que vivam sob suas leis, assumindo naturalmente uma projeção erga omnes. Já a autoridade da coisa julgada, que visa a impedir a renovação da discussão sobre a sentença por meio dos mecanismos da imutabilidade e da indiscutibilidade, seria restrita às partes entre as quais a decisão foi dada. Dessa forma, os terceiros indiretamente interessados na causa estariam sujeitos aos efeitos da sentença, que a eles se aplicariam imediatamente. A eles seria resguardado, contudo, o direito de

\footnotetext{
elemento declaratório. A insuficiência da teoria reside em não se distinguir o efeito material declaratório que caracteriza as ações declaratórias desse elemento declaratório, comum a todas as sentenças, relativo ao juízo de mérito formulado pelo juiz ao fim do processo. Confira-se a respeito item 2.3.2, adiante.

${ }^{224}$ NEVES, Celso. Contribuição ao estudo da coisa julgada civil, cit., p. 23.

${ }^{225}$ MARINONI, Luiz Guilherme; ARENHARDT, Sérgio. Manual do processo de conhecimento, cit., 2006.

${ }^{226}$ PORTO, Sérgio Gilberto. Coisa julgada civil. 3. ed. São Paulo: Ed. Revista dos Tribunais, 2006. p. 76.

${ }^{227}$ Endossam essa crítica de LIEBMAN na doutrina mais recente JOSÉ CARLOS BARBOSA MOREIRA, que afirma que todo o conteúdo da sentença é objeto da coisa julgada (Ainda e sempre a coisa julgada, cit., passim) e ELIO FAZZALARI, que afirma que a coisa julgada engloba o comando da sentença, independentemente de seu caráter declarativo, constitutivo ou condenatório (Il cammino della sentenza e della "cosa giudicata". Rivista di Diritto Processuale, Padova, v. 43, n. 3, p. 592-593, 1988).
} 
demonstrarem em juízo a injustiça da decisão ${ }^{228}$ em proteção às suas próprias esferas jurídicas, voltando a discutir a causa decidida, porque a coisa julgada ficaria sempre restrita às partes.

$\mathrm{Na}$ Itália, em que pese ter se perdido a ênfase em torno da polêmica, os pressupostos da teoria processual vieram a se difundir em tempos mais recentes, não apenas em razão do trabalho de LIEBMAN, mas também em razão do aprofundamento do estudo das relações entre direito e processo, por meio do conceito-chave de tutela jurisdicional, por autores mais recentes como Elio FAZZALARI ${ }^{229}$ e ANDREA PROTO PISANI $^{230}$. Ao mesmo tempo, teoria de LIEBMAN, tanto em razão de seus inegáveis méritos, como também pela influência do autor com sua vinda a nosso país, encontrou ampla aceitação perante a doutrina nacional. Adotaram sua definição, sem ressalvas, FREDERICO Marques $^{231}$, Moacyr Amaral Santos ${ }^{232}$, Vicente Greco Filho ${ }^{233}$, CÂNDido Rangel DINAMARCO $^{234}$, entre outros. Sua definição da coisa julgada, contudo, embora houvesse constado do anteprojeto do Min. da Justiça ALFREDo BUZAID, acabou por ser modificada no Congresso Nacional e não chegou a ser totalmente encampada pelo Código de Processo Civil de 1973, que se afasta da teoria do mestre em dois pontos: ao definir instituto como eficácia, e não como qualidade; e ao mencionar como objeto da imutabilidade e indiscutibilidade a sentença, e não seus efeitos. É importante observar que o artigo 467 do Código de Processo Civil definiu a coisa julgada como eficácia, mas não atribuiu essa eficácia à própria sentença, de modo que tampouco se pode dizer que nossa lei tenha se filiado à teoria da eficácia da declaração. Na realidade, tendo o legislador associado as duas propriedades da coisa julgada (imutabilidade e indiscutibilidade) a não estar mais sujeita, a sentença, aos recursos ordinários ou extraordinários, parece mais correto dizer que, segundo a lei brasileira, a coisa julgada é efeito do trânsito em julgado. Quanto a dizer incidir a coisa julgada sobre a sentença (causa), e não sobre os efeitos por ela produzidos

\footnotetext{
${ }^{228}$ A expressão "injustiça da decisão", na obra de LIEBMAN, diz respeito à contrariedade ao direito no conteúdo da sentença, e não se estende à sentença inválida por vício de forma (Eficácia e autoridade da sentença, cit., p. 139). Assim, os terceiros prejudicados podem vir a juízo para discutirem o mérito da decisão que prejudicou seus interesses conexos, com a finalidade de se subtraírem a seus efeitos, mas não para discutirem nulidades no processo em que ela foi dada.

${ }^{229}$ FAZZALARI, Elio. Note in tema di diritto e processo. Milano: Giuffrè, 1957.

${ }^{230}$ PROTO PISANI, Andrea. Le tutele giurisdizionali dei diritti: studi. Napoli: Jovene, 2003.

${ }^{231}$ MARQUES, José Frederico. Instituições de direito processual civil. 3. ed. Rio de Janeiro: Forense, 1966. v. 4 , p. 323.

${ }^{232}$ SANTOS, Moacyr Amaral. Primeiras linhas de direito processual civil. 3. ed. São Paulo: Saraiva, 1979. v. 3 , p. 39 e 47.

${ }^{233}$ GRECO FILHO, Vicente. Direito processual civil brasileiro. 20. ed. São Paulo: Saraiva, 2009. v. 2, p. 274.

${ }^{234}$ DINAMARCO, Cândido Rangel. Instituições de direito processual civil, cit., v. 3, p. 309-311.
} 
(conseqüências), a lei também parece ter adotado postura mais acertada, conforme a evolução da doutrina - a começar pelos reparos que o próprio LIEBMAN acrescentou à sua definição - viria a evidenciar.

A teoria da coisa julgada, no Brasil, que já contava com as profundas monografias de Guilherme Estellita e Celso Neves, ainda viria a se beneficiar da profícua polêmica instaurada entre José Carlos Barbosa Moreira e Ovídio Baptista da Silva, em que foram dissecados não apenas o conceito de coisa julgada, como também a teoria da sentença e de seus efeitos, que constituem pressuposto fundamental para a adequada compreensão do tema, sem, contudo, resolver o problema de definir o núcleo sobre o qual incide a estabilidade da coisa julgada. O passo definitivo para que se atingisse essa definição foi dado por José IGNÁCIO BotElHO DE MESQUITA, ao delinear os contornos da eficácia declaratória das sentenças e distingui-la do elemento declaratório contido no dispositivo, e situar apenas sobre este último a coisa julgada.

Para além do enfoque dogmático processual, a teoria da coisa julgada também se beneficiou dos aportes interdisciplinares de processualistas brasileiros que trouxeram elementos de outros campos do conhecimento. Nesse sentido, por exemplo, CÂNDIDO RANGEL DINAMARCO analisa a coisa julgada sob o enfoque da teoria política e a classifica como um mecanismo de imunização do ato de poder, indispensável para a afirmação da autoridade do Estado ${ }^{235}$. Outros processualistas ainda buscaram definir a coisa julgada a partir de investigações que aproximam a ciência do direito dos campos de investigação da teoria da comunicação, seja pelas vertentes da semiótica ou da retórica. Seguindo a primeira linha, WiLlis SANTIAgo GUERRA FilHo define a coisa julgada como um instituto tipicamente processual, consistente em um signo funcionalizado à organização do discurso comunicativo dentro do processo. Operando em um ambiente abstrato e formal, a sua função é apenas sintática ou operativa, de modo que o conceito não se refere a uma realidade concreta. Nesse prisma, a coisa julgada é indissociável do conceito de sentença, a que se reporta, e em relação à qual exerce também funções de legitimação ${ }^{236}$. A linha lingüística de conceituação contou com seguidores, dentre eles ELícIO DE CRESCI SobRINHO, que acrescenta a idéia de que a coisa julgada se erige como um topos

\footnotetext{
${ }^{235 ،(. . .) ~ o ~ q u e ~ i m p o r t a ~ s a l i e n t a r ~ e ́ ~ q u e ~ a ~ i m u n i z a c ̧ a ̃ o ~ d a s ~ d e c i s o ̃ e s ~ f u n d a d a s ~ n o ~ p o d e r ~ c o n s t i t u i ~ e n e ́ r g i c a ~}$ afirmação do poder mesmo, o qual sem isso ficaria sujeito a tantas impugnações que afinal terminaria por não prevalecer sobre as pessoas (então, supostamente) sujeitas a ele" (DINAMARCO, Cândido Rangel. A instrumentalidade do processo, cit., p. 112). Também do mesmo autor, Instituições de direito processual civil, cit., v. 3, p. 300-302.

${ }^{236}$ GUERRA FILHO, Willis Santiago. Reflexões a respeito da natureza da coisa julgada como problema filosófico. Revista de Processo, São Paulo, n. 58, p. 244 e ss., abr./jun. 1990.
} 
$\operatorname{argumentativo~}^{237}$, e LUIZ GUILHERME MARINONI, que, em uma linha mais aproximada da retórica, afirma que a coisa julgada é uma regra-condição para que o discurso jurídico possa ser institucionalizado de forma limitada no tempo, e imprescindível, por isso, para caracterização como um discurso prático ${ }^{238}$.

\subsubsection{Distinção entre a eficácia da sentença e a coisa julgada}

O avanço mais notável da teoria da coisa julgada, nesse percurso de cerca de um século de investigações sob a concepção publicística, foi resultado de um curto ensaio publicado em 1935 por ENRICO TUlLIO LIEBMAN, o já referido Efficacia ed autorità della sentenza. A originalidade desse trabalho, ao mesmo tempo simples e revolucionário, está na premissa que o seu autor enuncia logo nas primeiras páginas: a de que a coisa julgada não se confunde com os efeitos da sentença, em geral, e nem tampouco com o seu efeito declaratório, como propunha a doutrina dominante. Segundo essa concepção, que permanece válida para praticamente $\operatorname{toda}^{239}$ a doutrina que se seguiu, a coisa julgada se constitui em algo diferente, externo à sentença, que a ela se agrega pela conveniência social de que o julgado se torne estável. $\mathrm{Na}$ sistematização proposta posteriormente por JAIME GUASP, pode se dizer que essa distinção se refere a duas ordens de efeitos irradiados pelo processo: efeitos jurídico-materiais (alterações produzidas pela sentença, considerada como fato jurídico) e efeitos jurídico-processuais (a coisa julgada) ${ }^{240}$.

Afirmava LiEBMAN, pois, que "todos os efeitos possíveis da sentença (declaratório, constitutivo, executório) podem, de igual modo, imaginar-se, pelo menos em sentido

\footnotetext{
${ }^{237} \mathrm{O}$ autor nega, em razão da função sintática que ela assume no argumento, que haja uma substância na coisa julgada que permita lhe atribuir uma natureza autônoma, independente da sentença, que é o objeto sobre o qual ela incide; "a máxima, enquanto Tō $\pi$ o (tópos), pode ser utilizada ainda hoje, desde que se aceite sua flexibilidade, já por ser um ponto de vista e, dessarte, discutível” (CRESCI SOBRINHO, Elício de. Coisa julgada. Revista de Processo, São Paulo, n. 65, p. 243, jan./mar. 1992).

${ }^{238}$ MARINONI desenvolve sua concepção da coisa julgada a partir de conceitos da Teoria da argumentação jurídica de ROBERT ALEXY, e curiosamente chega a resultados que são bastante afins àqueles que CÂNDIDO DINAMARCO atingiu na Instrumentalidade do processo, cit. Afirma ele, nesse sentido, que "a coisa julgada é uma condição para o discurso jurídico. Um discurso revisável não é um discurso jurídico, mas um discurso prático-geral. A coisa julgada não integra o discurso propriamente dito, mas a parte formal da argumentação. Ela é uma regra indispensável à existência do discurso jurídico mesmo." (MARINONI, Luiz Guilherme. Coisa julgada inconstitucional. São Paulo: Ed. Revista dos Tribunais, 2008. p. 184).

${ }^{239} \mathrm{~A}$ exceção a ser feita concerne apenas aos autores, já mencionados no item anterior, que continuaram fiéis da teoria da eficácia da declaração.

${ }^{240}$ GUASP, Jaime; ARAGONESES, Pedro. Derecho procesal civil: introducción y parte general, cit., t. 1, p. 571-588.
} 
puramente hipotético, produzidos independentemente da autoridade da coisa julgada, sem que por isso se lhe desnature a essência". ${ }^{241}$ A maior prova disso está em que a sentença pode irradiar seus efeitos antes mesmo do trânsito em julgado, quando a lei o permitir: o exemplo cogitado é o da hipoteca judiciária. A teoria se aplica de forma ainda mais clara no direito brasileiro, em que se constata a existência de toda uma classe de sentenças cujos efeitos se sentem de forma imediata, independentemente do trânsito em julgado (que é pressuposto de formação da coisa julgada: art. 467, CPC), pelo fato de o recurso de apelação ser desprovido de aptidão para suspender seus efeitos: assim ocorre com as sentenças que homologam a divisão ou a demarcação, com as que condenam à prestação de alimentos, com as que decidem o processo cautelar ou rejeitam os embargos à execução, com as que julgam procedente o pedido de instituição de arbitragem, com as que confirmam a antecipação dos efeitos da tutela, bem como com aquelas proferidas em mandado de segurança e ação civil pública.

Prosseguindo pela linha que vimos adotando no presente trabalho, no sentido de identificar o campo de atuação de cada um dos fenômenos relacionados à sentença e à coisa julgada, podemos também identificar que as eficácias ou efeitos da sentença, ao contrário da coisa julgada, destinam-se a incidir sobre o plano das relações jurídicas materiais, ou seja, elas são preordenadas a adquirirem relevância externa ao processo. Como anota SÉrgio GiLberto Porto, pois, "a eficácia é atributo da sentença, e não da coisa julgada, pois esta não produz efeitos e, sim, apenas torna o ato imutável e indiscutível, na medida em que é a sentença, através de seus comandos, que se mostra capaz de produzir os resultados almejados pela demanda, os quais são representados pela composição das eficácias que habitam o conteúdo da decisão"242. De fato, as diferentes eficácias da sentença se destinam a incidir sobre a crise de direito material estabelecida entre as partes, constituindo uma nova relação ou situação jurídica, vinculando seu comportamento a uma declaração de certeza, ou sujeitando o devedor a medidas interventivas por parte do Estado enquanto não satisfizer a obrigação.

A coisa julgada, de seu turno, é algo de substancialmente diferente que consiste, mais exatamente, em "um modo de manifestar-se e produzir-se dos efeitos da própria sentença da própria sentença, algo que a esses efeitos se ajunta para qualificá-los e reforçá-

\footnotetext{
${ }^{241}$ LIEBMAN, Enrico Tullio. Eficácia e autoridade da sentença, cit., p. 23.

${ }^{242}$ PORTO, Sérgio Gilberto. Coisa julgada civil, cit., p. 56-57 (destaque nosso).
} 
los em sentido bem determinado" ${ }^{\text {243 }}$. Isto ocorre não por um imperativo imanente, mas por motivos de conveniência social que recomendam a estabilidade das decisões. Ela se definiria assim como "uma qualidade, mais intensa e mais profunda, que reveste o ato também em seu conteúdo e torna assim imutáveis, além do ato em sua existência formal, também os efeitos, quaisquer que sejam, do próprio ato" ${ }^{244}$. Definida como qualidade dos efeitos da sentença, que os tornam imutáveis e indiscutíveis, a coisa julgada se qualifica para LIEBMAN como instituto de direito público, e mais exatamente, do direito constitucional.

\subsubsection{A evolução da formulação original de Liebman: as contribuições de Ovídio Batista e de Barbosa Moreira}

Embora tenha alcançado grande projeção, especialmente no Brasil, a definição de coisa julgada trazida por LIEBMAN no ensaio "Eficácia e autoridade da sentença" parecia produzir algum incômodo, ao localizar a estabilidade da coisa julgada nos efeitos da sentença. Afinal, a experiência mostra que estes são ordinariamente transitórios, de modo que "a quem observe com atenção a realidade da vida jurídica, não se pode deixar de impor uma verdade muito simples: se alguma coisa (...) escapa ao sêlo da imutabilidade, são justamente os efeitos da sentença" ${ }^{245}$, como observou BARBOSA MOREIRA, aprofundando e desenvolvendo a crítica à definição liebmaniana que já havia sido feita anos antes por ENRICO ALLORIO. ${ }^{246}$ De fato, a eficácia executória se exaure com a satisfação da pretensão, a eficácia constitutiva se exaure imediatamente com a modificação da situação jurídica, enquanto a eficácia declaratória persiste somente enquanto não houver circunstâncias supervenientes que influam sobre o direito declarado.

\footnotetext{
${ }^{243}$ LIEBMAN, Enrico Tullio. Eficácia e autoridade da sentença, cit., p. 41.

${ }^{244}$ LIEBMAN, Enrico Tullio. Eficácia e autoridade da sentença, cit., p. 51.

${ }^{245}$ BARBOSA MOREIRA, José Carlos. Ainda e sempre a coisa julgada, cit., p. 139. Na doutrina estrangeira recente, essa também é a opinião comum, como expõe ANDREA PROTO PISANI: "il diritto o rapporto accertato dalla sentenza passata in giudicato continua però a vivere, a svolgersi anche dopo il giudicato. Di chi la pacifica operatività su di esso dei fatti estintivi o modificativi dei fatti sopravvenuti" (Lezioni di diritto processuale civile, cit., p. 64).

246“'Ad opera delle parti, poi, gli effetti giuridici, quali che siano, prodotti dalla sentenza, non sono affatto sottrati a futuri mutamenti; essi soggiacciono anzi, in toto, al libero potere di dizposizione delle parti, con l'unico limite che può derivare dalla natura degli stessi rapporti. Il vero è che immutabili non sono gli effetti della sentenza; immutabile è la stessa sentenza" (ALLORIO, Enrico. La cosa giudicata rispetto ai terzi, cit., p. 40). Na doutrina brasileira, também PONTES DE MIRANDA havia feito o mesmo reparo à teoria liebmaniana. (Comentários ao Código de Processo Civil: arts. 444 a 475, cit., t. 5, p. 109).
} 
A transitoriedade dos efeitos da sentença, concebidos para se exaurirem como os atos jurídicos em geral, foi explicada pela teoria de LIEBMAN com a figura da cláusula rebus sic stantibus ${ }^{247}$. Evidentemente, ao tentarmos aplicar esse conceito à teoria da coisa julgada, incorremos em uma tautologia, porque estamos a dizer que os efeitos da sentença são imutáveis, mas apenas enquanto não se modificarem... Tinha toda a razão EDUARDO COUTURE ao afirmar que a construção é, no mínimo, paradoxal ${ }^{248}$.

Na realidade, pensamos que neste aspecto a formulação original de LIEBMAN pode ser considerada parcialmente superada, especialmente pelo fato de que o próprio autor veio a reconhecer a pertinência da crítica aqui analisada (mantendo, porém, a sua definição) ${ }^{249}$. Voltando a analisar a definição proposta em seu ensaio após quarenta e três anos de sua publicação na Itália ${ }^{250}$, o fundador da Escola de Direito Processual de São Paulo reconheceu a necessidade de "esclarecer melhor o que se entende por imutabilidade (ou incontestabilidade) dos efeitos da sentença" "251, dizendo que a expressão "não significa, naturalmente que fatos sucessivos não possam modificar a situação e a relação entre as partes". O que a coisa julgada impediria, na realidade, seria "um novo juízo sobre o que foi validamente decidido por intermédio da sentença que representa a disciplina concreta da relação jurídica controvertida". Essas observações, indo além do simples esclarecimento, consistem substancialmente em uma parcial revisão de sua clássica definição, na parte em que situava a imutabilidade nos efeitos da sentença. Por elas se reconhece que é no juízo sobre a disciplina concreta da relação controvertida que se situa a autoridade da coisa julgada, e não nos efeitos da sentença, transitórios que são como todas as situações jurídicas substanciais.

À parte esses temperamentos que lhe foram postos pelo próprio autor, a definição de coisa julgada em LiEBMAN foi objeto de profícua discussão ao longo da extensa polêmica que envolveu os processualistas OvíDIo BATISTA DA SILVA e José CARLOS BARBOSA MOREIRA, a partir da publicação do artigo Ainda e sempre a coisa julgada pelo

\footnotetext{
${ }^{247}$ LIEBMAN, Enrico Tullio. Eficácia e autoridade da sentença, cit., p. 27.

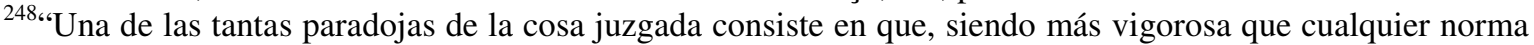
del orden jurídico, es al mismo tiempo tan frágil que puede modificarla un simple acuerdo de los particulares, en cuanto a los derechos y obligaciones en ella atribuídos". (COUTURE, Eduardo. Fundamentos del derecho procesal civil, cit., p. 328).

${ }^{249} \mathrm{O}$ mesmo registro é feito por JOSÉ ROGÉRIO CRUZ E TUCCI (Limites subjetivos da eficácia da sentença e da coisa julgada civil, cit., p. 92).

${ }^{250}$ LIEBMAN, Enrico Tullio. Efeitos da sentença e coisa julgada. In: Eficácia e autoridade da sentença e outros escritos sobre a coisa julgada. Tradução de Alfredo Buzaid e Benvindo Aires, com notas de Ada Pellegrini Grinover. 4. ed. Rio de Janeiro: Forense, 2007. p. 274-284. O texto foi originalmente publicado em alemão no periódico Zeitschrift für Zivilprozess, v. 91, n. 4, de out./1978.

${ }^{251}$ LIEBMAN, Enrico Tullio. Efeitos da sentença e coisa julgada, cit., p. 281.
} 
último $^{252}$. As objeções levantadas por OvíDIO, ao longo da controvérsia, são feitas a partir da teoria da eficácia da declaração, tal como encampada em nosso país por PONTES DE MIRANDA, de forma conjugada à sua teoria das cargas de eficácia comuns à sentença de mérito (que somariam sempre uma "constante quinze"). O processualista gaúcho se manteve fiel aos postulados dessa teoria em seus escritos, introduzindo, porém, uma importante distinção entre o que se deva entender por efeito e eficácia da sentença (infra, neste mesmo item).

Já o processualista fluminense, no artigo citado e nos demais que se seguiram na polêmica, formula uma dupla crítica às correntes predominantes em torno da coisa julgada. De um lado, afirma ele que não é possível restringir a coisa julgada ao efeito declaratório contido na sentença, já que a condenação e a constituição recebem igualmente o mesmo tipo de estabilidade que as sentenças declaratórias. Assim, todo o seu conteúdo decisório de fundo declaratório, condenatório e constitutivo - seria destinatário da proteção oferecida pela coisa julgada material. De outro lado, ele critica a definição da coisa julgada como qualidade dos efeitos da sentença, crítica essa que, como vimos, foi assimilada implicitamente pelo próprio criador da teoria. BARBOSA MOREIRA vem a definir a coisa julgada como uma situação jurídica, que se forma a partir do trânsito em julgado, quando o conteúdo da sentença se transforma em imutável e indiscutível ${ }^{253}$. Essa definição é acolhida por AleXANDre Freitas CÂMARA ${ }^{254}$, José MARIA Rosa TESHEINER ${ }^{255}$, ANDRÉ NEKATSCHALOW $^{256}$ e JOSÉ ROGÉRIO CRUZ E TUCCI ${ }^{257}$, na bibliografia mais recente. Contudo, muito embora se deva conceder que as críticas de BARBOSA MoreIRA representaram uma grande contribuição para que se pudesse melhor compreender o modo de se manifestar da res judicata, verificamos que a sua própria proposta de definição para o

\footnotetext{
${ }^{252}$ A série de textos é composta, do lado de BARBOSA MOREIRA, pelos textos BARBOSA MOREIRA, José Carlos. Ainda e sempre a coisa julgada, cit.; Coisa julgada e declaração. In: Temas de direito processual: $1^{\text {a }}$ série. 2. ed. São Paulo: Saraiva, 1988. p. 81-89; Eficácia da sentença e autoridade da coisa julgada. In: _. Temas de direito processual: $3^{a}$ série. São Paulo: Saraiva, 1994. p. 99-113 e Conteúdo e efeitos da sentença: variações sobre o tema. In: ___ . Temas de direito processual: $4^{a}$ série. São Paulo: Saraiva, 1989. p. 175-183. Por OVÍDIO BAPTISTA, foram produzidos os artigos Eficácias da sentença e coisa julgada, Conteúdo da sentença e mérito da causa, e, finalmente, Conteúdo da sentença e coisa julgada. Todos eles estão referidos ao final desta dissertação.

${ }^{253 . " M a i s ~ e x a t o ~ p a r e c e ~ d i z e r ~ q u e ~ a ~ c o i s a ~ j u l g a d a ~ e ́ ~ u m a ~ s i t u a c ̧ a ̃ o ~ j u r i ́ d i c a: ~ p r e c i s a m e n t e ~ a ~ s i t u a c ̧ a ̃ o ~ q u e ~ s e ~}$ forma no momento em que sentença se converte de instável em estável. É a essa estabilidade, característica da nova situação jurídica, que a linguagem jurídica se refere, segundo pensamos, quando fala da "autoridade da coisa julgada"” (BARBOSA MOREIRA, José Carlos. Eficácia da sentença e autoridade da coisa julgada, cit., p. 113).

${ }^{254}$ CÂMARA, Alexandre Freitas. Lições de direito processual civil. Rio de Janeiro: Lumen Iuris, 2005. v. 1, p. 472.

${ }^{255}$ TESHEINER, José Maria Rosa. Eficácia da sentença e coisa julgada no processo civil. São Paulo: Ed. Revista dos Tribunais, 2002. p. 72-78.

${ }^{256}$ NEKATSCHALOW, André. A coisa julgada nas relações continuativas, cit., p. 58-66.

${ }^{257}$ CRUZ E TUCCI, José Rogério. Limites subjetivos da eficácia da sentença e da coisa julgada civil, cit., p. 91-92.
} 
instituto acabou por se mostrar um tanto imprecisa ao afirmar que é o conteúdo da sentença que se torna imutável e indiscutível. Ora, a sentença contém muitos elementos, mesmo em sua parte dispositiva (o dispositivo contém a enunciação de um juízo conclusivo a respeito da lide, a manifestação da vontade do Estado associada a essa conclusão, e as eficácias que lhe seguem), e não se pode dizer que todos sejam imutáveis.

Segundo nos parece, essa imprecisão decorreu da dificuldade que o autor teve em distinguir, dentre as possíveis acepções do vocábulo "declaração" (Festellung), os fenômenos da eficácia declaratória (como imperium) e do elemento declaratório (como decisum). De fato, uma dificuldade que sempre se colocou como obstáculo à teoria processual da coisa julgada, em sua empresa de separar as noções de eficácia da sentença e da coisa julgada, foi a de se distinguir uma eficácia declaratória na sentença, destinada a operar no ambiente externo ao processo, que não se confundisse com a declaração conclusiva do juiz acerca da procedência ou improcedência da pretensão processual $^{258}$. E no que diz respeito especificamente à declaração, BARBOSA MOREIRA, que declaradamente se propunha o objetivo de levar a fundo a separação iniciada por LIEBMAN ${ }^{259}$, não chegou realmente a estabelecer tal distinção.

Pois se é verdade que nos escritos trocados com OvíDIO BAPTISTA o professor fluminense demonstrou que existe um elemento declaratório contido em toda sentença de mérito $^{260}$, ele não chegou a distingui-lo do efeito declaratório da sentença, destinado a operar no plano material. A própria idéia de uma eficácia declaratória material parece ser

\footnotetext{
${ }^{258}$ O problema foi lançado por PONTES DE MIRANDA, que, criticando a afirmação de LIEBMAN de que se pode conceber uma eficácia declaratória anterior ao trânsito em julgado, se pergunta: “¿É concebível a eficácia da declaração sem a eficácia da coisa julgada material? (...) A prova teria de consistir em se apontar força ou efeito declarativo que não fosse a força ou efeito de coisa julgada" (Comentários ao Código de Processo Civil, cit., t. 4, p. 157) É corrente na doutrina a tendência de se identificar o juízo de subsunção do caso à norma jurídica, isto é, o juízo de mérito com a eficácia declaratória, derivando-se daí que toda sentença tem efeito declaratório, a ele podendo se acrescentar também os constitutivos ou condenatórios. Por todos, MOACYR AMARAL SANTOS afirma que "toda sentença, assim, se traduz numa declaração de direito, compondo a lide. De um modo geral, poder-se-á dizer que toda sentença tem efeito declaratório. E há sentenças que se esgotam com a simples declaração; outras, entretanto, à declaração acrescentam alguma coisa, pela qual se distinguem" (Primeiras linhas de direito processual civil, cit., v. 3, p. 27).

${ }^{259}$ De fato, o autor formulava crítica no sentido de ter faltado "a Liebman dar o passo decisivo no sentido de libertar da problemática relativa à eficácia da sentença a teoria da coisa julgada. Atrevemo-nos a pensar que a doutrina tanto mais se habilitará a lidar proveitosamente com as complexíssimas questões que aí palpitam, quanto maior for a clareza com que se lhe deparar a visão dessa fundamental autonomia" (Ainda e sempre a coisa julgada, cit., p. 146).

260“'A sentença - toda sentença - contém uma declaração, podendo conter ou não, junto dela, um aliud. Falarse-á, pois, do conteúdo declaratório da sentença, ou do elemento declaratório presente neste conteúdo. No particular, é incensurável a dicção da lei italiana: 'L'accertamento contenuto nella sentenza..."” (BARBOSA MOREIRA, José Carlos. Coisa julgada e declaração, cit., p. 86).
} 
negada pelo autor ${ }^{261}$. Tudo o que haveria na sentença, em seu modo de entender, seria a declaração sobre o juízo de mérito alcançado, que se poderia chamar indistintamente de conteúdo declaratório ou elemento declaratório. E o conceito de eficácia declaratória se confundiria com o de juízo de mérito, fundidas ambas essas acepções do vocábulo “declaração" no conceito único de "conteúdo declaratório".

Talvez OvíDIO BAPTISTA DA SILVA tenha chegado mais perto de enxergar essa distinção ao separar os conceitos de efeito declaratório (como "potência" contida na sentença) de eficácia declaratória (como "resultado" por ela produzido na realidade externa ao processo) ${ }^{262}$. Dando esse passo, OvíDIo se afastou da concepção de coisa julgada de PONTES DE MiRANDA, a que se alinhava no início da polêmica, e alcançou resultados muito interessantes, prejudicados em certa medida por ter se mantido ainda preso à terminologia da obra do processualista alagoano ao sistematizar a sua teoria. $\mathrm{O}$ interessante de se observar é que, ao afirmar que a coisa julgada se localiza sobre a eficácia declaratória, o autor gaúcho a definiu como “o juízo de subsunção praticado pelo legislador, ao considerar incidente no caso concreto a regra normativa constante da lei"263, e não como qualquer alteração ou potência de alteração na realidade jurídica. Note-se assim que a eficácia declaratória em que OvíDIO BAPTISTA situa a estabilidade da coisa julgada não é realmente uma eficácia, pelo menos no sentido que ele próprio dá à palavra: ela não consiste em potência de alteração da realidade externa à sentença (que, a rigor, seria nula nas sentenças de improcedência), mas em um juízo. É por isso que, apesar de considerarmos sua teoria insuficiente para explicar a coisa julgada, nela reconhecemos uma intuição que bem apreende o fenômeno.

\footnotetext{
${ }^{261}$ Isso se depreende do seguinte trecho: "aludir (...) ao efeito declaratório da sentença, a rigor, c'est parler pour ne rien dire. Quando a uma declaração se atribui efeito declaratório, ou se está embutindo a priori neste conceito uma significação que a fórmula mal exprime, ou se está pura e simplesmente perpetrando uma tautologia: a declaração produz o efeito... de declarar!" (BARBOSA MOREIRA, José Carlos. Coisa julgada e declaração, cit., p. 87).

${ }^{262} \mathrm{~A}$ interessante e sutil distinção introduzida pelo processualista gaúcho foi assim formulada: "levando em conta o que acaba de ser visto, cremos chegado o momento de estabelecer uma distinção fundamental, nem sempre levada em conta pelos processualistas, entre eficácias e efeitos da sentença. A primeira categoria - a das eficácias - faz parte do conteúdo da sentença, que com virtualidade operativa capaz da produção de efeitos, ao passo que estes, quer se produzam no mundo jurídico, quer no mundo dos fatos, hão de ter-se como atualizações, no sentido aristotélico, das eficácias" (Conteúdo da sentença e coisa julgada. In: SILVA, Ovídio Baptista. Sentença e coisa julgada: ensaios e pareceres, cit., p. 176). Na bibliografia mais recente, a ela prestam adesão LUIZ GUILHERME MARINONI-SÉRGIO CRUZ ARENHARDT (MARINONI, Luiz Guilherme; ARENHARDT, Sérgio. Manual do processo de conhecimento, cit., p. 362) e SĖRGIO GILBERTO PORTO (Coisa julgada civil, cit., p. 76).

${ }^{263}$ SILVA, Ovídio Baptista. Conteúdo da sentença e coisa julgada, cit., p. 172.
} 


\subsubsection{A elaboração de Botelho de Mesquita: eficácia declaratória e elemento declaratório}

Publicada alguns anos mais tarde, a contribuição doutrinária que trouxe clareza para a definitiva separação dos planos do direito material e do direito processual na teoria da coisa julgada foi a do professor do Largo de São Francisco José IGNÁcio Botelho DE MESQUITA. Para esse processualista, a adequada compreensão do conceito de coisa julgada exige exatamente a distinção entre o elemento declaratório, que se faz presente em todas as sentenças de mérito; e o efeito declaratório, que é irradiado apenas pelas sentenças que julguem procedente a pretensão declaratória deduzida em juízo.

Conforme explica Botelho de Mesquita, o efeito declaratório "consiste num vínculo imposto pela sentença, não só às partes como também a terceiros, e especialmente aos órgãos estatais, que os sujeita a tomar como norma para seus atos jurídicos a declaração pronunciada pelo juiz" ${ }^{264}$. De fato, o que torna relevante a tutela declaratória não é o juízo lógico de subsunção feito pelo juiz, ou a mera afirmação da certeza do direito controvertido. $\mathrm{O}$ que lhe confere o status de um bem jurídico, que se constitui no objeto autônomo de uma pretensão jurisdicional, é o seu caráter imperativo, a sua capacidade de impor a adequação do comportamento das partes (e também de terceiros) àquilo que foi declarado. Por exemplo, declarada a nulidade do contrato de mútuo, é vedado ao credor protestar o título representativo da dívida. Declarada a aquisição da propriedade do imóvel por usucapião, é vedado ao antigo dono, vencido, celebrar contrato alienando o bem a um terceiro. É exatamente nesse sentido que ALFREDO BUZAID fala no "valor normativo do juízo declaratório" ${ }^{265}$. Esse vínculo tem natureza material, e a sentença jurisdicional não é a sua fonte exclusiva. Atos jurídicos de natureza negocial, como a confissão de dívida, a quitação, a proposta de contrato, vinculam de maneira similar o comportamento dos indivíduos que declaram sua vontade neste ou naquele sentido.

De outro lado, o elemento declaratório da sentença, em que se concentra a estabilidade proporcionada pela coisa julgada, não se confunde com a eficácia declaratória, pois aquele consiste na conclusão de um raciocínio sobre a pretensão deduzida em juízo.

\footnotetext{
${ }^{264}$ BOTELHO DE MESQUITA, José Ignácio. A coisa julgada. In: . A coisa julgada. Rio de Janeiro: Forense, 2006. p. 9.

265،A sentença passada em julgado valerá como 'preceito'. Qual o sentido do vocábulo preceito? A nosso ver, quer ele dizer que o juízo declaratório será um juízo normativo, isto é, regulador da situação das partes”. BUZAID, Alfredo. Ação declaratória. São Paulo: Livraria acadêmica Saraiva e Cia., 1943. p. 182.
} 
Ocorre que este raciocínio conclusivo pode muito bem dizer respeito às pretensões constitutiva e condenatória; assim, em face da elaboração de BOTELHO DE MESQUTTA, revela-se improcedente a crítica liebmaniana que sustenta que a localização da res judicata no elemento declaratório deixaria desprotegidas a condenação e a constituição.

Como esclarece WALter PIVA Rodrigues, substancialmente, “a imutabilidade alcança a proteção à disciplina da relação que entre as partes ficou estabelecida na sentença"266. Na mesma linha de pensamento, JOÃO DE CASTRO MENDES sustenta que "aquilo que primariamente recebe força de caso julgado é o conteúdo de pensamento, ou afirmação, contido na parte dispositiva material da sentença: é o thema decisum" ${ }^{267}$. Em outras palavras, a coisa julgada se forma sobre o elemento declaratório da sentença, e esta expressão deve ser entendida como um juízo: a conclusão última do raciocínio do juiz sobre o mérito da causa ${ }^{268}$. Na imutabilidade e indiscutibilidade dessa conclusão, precisamente, é que reside a essência do instituto.

O elemento declaratório passível de aquisição de estabilidade para fora do processo tem por objeto necessário o mérito da causa. É por tal razão que o art. 268 do Código de Processo Civil ressalva da autoridade da coisa julgada as sentenças que extingam o processo sem resolver-lhe o mérito, por vícios formais no desenvolvimento da relação processual (ausência de pressupostos processuais) ou por ausência de pressupostos de admissibilidade de julgamento do mérito (carência de ação) ${ }^{269}$. E nem seria necessário ou

\footnotetext{
${ }^{266}$ PIVA RODRIGUES, Walter. Coisa julgada tributária, cit., p. 69.

${ }^{267}$ MENDES, João de Castro. Limites objectivos do caso julgado em processo civil. Lisboa: Ática, 1968. p. 254.

${ }^{268}$ A expressão é de CHIOVENDA: “(...) objeto do julgado é a conclusão última do raciocínio do juiz, e não as premissas; o último e imediato resultado da decisão, e não a série dos fatos, das relações e dos estados jurídicos que, no espírito do juiz, constituíram os pressupostos de tal resultado" (Instituições de direito processual civil, cit., v. 1, p. 411).

${ }^{269}$ Deve se registrar, no entanto, que parte da doutrina considera que as condições da ação, na realidade, constituem questões de mérito que são passíveis de receberem a autoridade da coisa julgada material. É o que defendem, entre outros, GALENO LACERDA (Despacho saneador. 3. ed. Porto Alegre: Sérgio Antonio Fabris, 1990. p. 88-89) e SUSANA HENRIQUES DA COSTA (Condições da ação. São Paulo: Quartier Latin, 2005). Em uma linha intermediária, outros autores manifestam o entendimento de que a decisão a respeito das condições da ação se tornaria imutável por efeito da coisa julgada formal, em outros processos em que a mesma lide fosse reiterada. É a posição defendida por LUIZ EDUARDO RIBEIRO MOURÃO (Coisa julgada. Belo Horizonte: Editora Fórum, 2008. p. 141-151) e por JOSÉ IGNÁCIO BOTELHO DE MESQUITA, MARIANA CAPELA LOMBARDI, RODOLFO COSTA MANSO AMADEO, LUIZ GUILHERME PENNACCHI DELLORE E DANIEL GUIMARÃES ZVEIBIL (O colapso das condições da ação? um breve ensaio sobre os efeitos da carência de ação. Revista do Advogado, São Paulo, v. 88, p. 109-127, 2006). Tal enfoque descortina uma realidade interessantíssima e pouco explorada pela doutrina, de que nos ocuparemos no capítulo conclusivo desta dissertação: a estabilidade extraprocessual de decisões sobre questões ligadas ao mérito, circunscrita ao âmbito de processos voltados à solução da mesma lide. Sem entrar em maiores detalhes pelo momento, limitamo-nos a dizer que esse tipo de vínculo processual que tem por objeto parte da resolução da lide não se amolda às características tradicionalmente reconhecidas à coisa julgada formal, e nem tampouco àquelas que definem a coisa julgada material, o que sugere a existência de uma terceira forma de expressão da coisa julgada.
} 
adequado que a coisa julgada os abrangesse: os vícios de forma dizem respeito, obrigatoriamente, àquele processo específico, e podem ser sanados futuramente sem que haja óbice à análise do mérito. Quanto às condições da ação, cuja presença ou ausência deve ser possível em uma análise abstrata e ainda superficial da demanda, a desnecessidade da formação de coisa julgada parte da pressuposição da simplicidade dessa aferição.

Pois bem. Essa elaboração sofisticada, que leva até o final a separação entre os planos do direito material e processo, tem importantes repercussões práticas que justificam o trabalho de abstração empreendido. A mais evidente delas, fornecida pelo próprio autor, é a de explicar por que razões a sentença que julga improcedente a pretensão declaratória faz coisa julgada apenas nos limites da lide por ela resolvida, e não se estende sobre a declaração inversa da pretendida pelo autor, nem no plano dos efeitos, e nem no plano do juízo formulado pelo juiz. A teoria fornece assim bases firmes para rejeitar o caráter dúplice que parte da doutrina processual atribui à ação declaratória ${ }^{270}$.

Tomemos como exemplo o contribuinte do imposto predial que postule a declaração de inexistência de relação jurídica tributária, fundada na inconstitucionalidade da fórmula de progressividade de alíquotas prevista pela lei municipal. A tutela pretendida consiste em uma eficácia declarativa material, que vincule o Fisco à declaração de inexistência da relação tributária. Sendo julgada improcedente essa pretensão, a sentença conterá em seu elemento declaratório um juízo conclusivo sobre a impertinência do pedido à luz do fundamento invocado. O vínculo externo, contudo, não se produz: a sentença de improcedência não tem o efeito declaratório que vincule o comportamento das partes nem à inexistência da relação tributária e nem à sua existência, porque o julgamento não poderia ultrapassar os limites da pretensão processual ${ }^{271}$. Sendo o elemento declaratório

\footnotetext{
${ }^{270}$ MARQUES, José Frederico. Instituições de direito processual civil, cit., v. 4, p. 306; PONTES DE MIRANDA, Francisco Cavalcanti. Comentários ao Código de Processo Civil, cit., t. 4, p. 111-112. CÂNDIDO RANGEL DINAMARCO, após expor essa tradicional doutrina de origem germânica, em cujo contexto pode se admitir a tese do caráter dúplice da declaratória desde que se adote também o critério da individuação da causa de pedir, vem manifestar a sua contrariedade à solução proposta para o processo civil brasileiro, afirmando que o "elegantíssimo tema" está a merecer maiores desenvolvimentos por nossa doutrina. "É mais do que razoável" - afirma - a ressalva que a doutrina vem fazendo, referente às sentenças que julgam improcedente a ação declaratória negativa. Sustenta-se que é um exagero equiparar a eficácia dessa sentença à das que julgam procedente a ação declaratória positiva ou condenatória, dado que aquela se atém aos limites da lide proposta. Ou seja, a sentença que julga improcedente a ação declaratória negativa limita-se a declarar que, pelos fundamentos expostos pelo autor, não há razão para reputar-se inexistente a relação jurídica impugnada (CPC, art. 128) - sem se pronunciar a propósito de algum outro eventual fundamento para a inexistência" (Sentença meramente declaratória, sentença condenatória e coisa julgada. In: . Fundamentos do processo civil moderno. 6. ed. São Paulo: Malheiros Ed., 2010. v. 1, p. 978).

${ }^{27} \overline{1}$ Segundo WALTER PIVA RODRIGUES, "o que Botelho de Mesquita não aceita em relação à teoria de Liebman é o fato de que essa concepção parte do pressuposto de que todas as sentenças produzem efeitos (...) na sentença de improcedência, afirmou o expositor, há a recusa à produção de efeitos pretendidos pelo
} 
circunscrito à lide analisada, de outro lado, a coisa julgada somente impede que o contribuinte questione o tributo pelo mesmo fundamento de inconstitucionalidade, mas não haverá obstáculo a que o mesmo pedido seja renovado por fundamento diverso, como erro na aferição da área ou no valor venal do imóvel tributado. A se admitir o caráter dúplice das ações declaratórias, o resultado seria oposto: a segunda demanda, embora substanciada ${ }^{272}$ em causa de pedir distinta, ficaria também excluída da apreciação do Poder Judiciário. Dessa maneira a coisa julgada, que fique bem percebido, acabaria por transcender os limites do processo e daquilo que, nele, foi efetivamente discutido e decidido.

Em suma, pois, a coisa julgada pode ser definida como o efeito do trânsito em julgado, que torna imutável e indiscutível o elemento declaratório contido nas sentenças de mérito, sejam elas de procedência ou de improcedência. Deve-se essa definição à elaboração de José IGNÁcio BotelHo DE MESQuita, que embora apenas recentemente tenha sido publicada em forma de livro ${ }^{273}$, conta com adesão de WALTER PIVA Rodrigues $^{274}$, Luiz Guilherme Pennacchi Dellore ${ }^{275}$ e Mariana Capela LOMBARDI $^{276}$. Seu grande mérito consiste em ter identificado a natureza da eficácia correspondente às pretensões declaratórias, distinguindo e isolando seu conceito do juízo conclusivo de mérito que constitui o elemento declaratório de todas as sentenças de mérito. Com isso se superou a crítica dirigida à situação da coisa julgada sobre os efeitos sentenciais, e ao mesmo tempo se resguardou, da teoria de LIEBMAN, aquilo que ela tem de mais valioso: a separação da coisa julgada, instituto de direito processual que vincula as

autor, nada projetando em relação a terceiros" (Coisa julgada tributária, cit., p. 81). A interpretação examinada é de todo coerente com a regra do artigo 128 do Código de Processo Civil, segundo a qual "o juiz decidirá a lide nos limites em que foi proposta, sendo-lhe defeso conhecer de questões, não suscitadas, a cujo respeito a lei exige a iniciativa da parte", e é coerente com o princípio de que não pode o processo exercer efeitos em favor do réu sem que este manifestasse a iniciativa de requerê-los, por meio de reconvenção ou ação declaratória incidental.

${ }^{272}$ Fazemos aqui referência à substanciação da demanda, para anotar que muito embora a doutrina germânica entenda que, em alguns casos, a depender das especificidades da pretensão declaratória deduzida em juízo, a sentença de improcedência pode equivaler a uma declaração em sentido inverso (ROSENBERG, Leo. Tratado de derecho procesal civil. Buenos Aires: Ediciones Jurídicas Europa-América, 1955. t. 2, p. 471), naquele país existe a fundamental diferença de que a causa de pedir se identifica com a relação jurídica, em razão da adoção do critério da individuação da causa de pedir (Individualiserungsthese), que pode conduzir a uma maior extensão na coisa julgada. A respeito da teoria da individuação, confira-se JOSÉ ROGÉRIO CRUZ E TUCCI, A causa petendi no processo civil (3. ed. São Paulo: Ed. Revista dos Tribunais, 2009), e as considerações que mais adiante se fazem neste mesmo trabalho.

${ }^{273}$ BOTELHO DE MESQUITA, José Ignácio. A coisa julgada. Rio de Janeiro: Forense, 2006. Anteriormente à publicação do volume já havia referências à teoria feitas a partir de notas de aula do professor, como na tese de WALTER PIVA RODRIGUES (Coisa julgada tributária, cit.).

${ }^{274}$ PIVA RODRIGUES, Walter. Coisa julgada tributária, cit., p. 79-81.

${ }^{275}$ DELLORE, Luiz Guilherme Pennacchi. Das sentenças que não são cobertas pela coisa julgada no direito processual civil brasileiro, cit., p. 64-66.

${ }^{276}$ LOMBARDI, Mariana Capela. Da coisa julgada civil: limites subjetivos e extensão a terceiros. 2008. Dissertação (Mestrado) - Faculdade de Direito da Universidade de São Paulo, 2008. p. 18-20. 
partes ao resultado do processo, dos efeitos da sentença, que incidem diretamente sobre o plano material para vincular o comportamento das partes e também dos terceiros juridicamente interessados na causa.

\subsubsection{Efeito negativo da coisa julgada}

Estabelecidas a natureza processual da coisa julgada, e sua autonomia em relação à sentença e seus efeitos materiais, o passo seguinte consiste em determinar como se manifesta o vínculo que ela gera para os juízes em processos futuros. A doutrina atribui ao romanista LUDWIG KELLER ter diferenciado pela primeira vez o efeito ativo e o efeito negativo da exceção de coisa julgada ${ }^{277}$, tendo descrito pela primeira vez o modo em que se manifesta o primeiro. Não que o efeito ativo e o efeito negativo sejam entidades ontologicamente distintas: na realidade, trata-se de diferentes dimensões do mesmo fenômeno da intangibilidade do julgado, que se apresentam de maneira diferenciada a depender do ambiente em que seja colocada em risco a autoridade do julgado. Essa dupla configuração da coisa julgada foi reconhecida por nosso direito positivo, que define a coisa julgada como imutabilidade e indiscutibilidade da sentença (art. 467, Código de Processo Civil), correspondendo essas duas propriedades, respectivamente, ao efeito negativo e ao efeito positivo.

O efeito negativo, portanto, importa da vedação de modificação da sentença que tenha julgado a lide, tanto no mesmo processo (função que já é cumprida pela coisa julgada formal), como também em futuros processos em que se reitere a mesma causa que já tenha sido decidida. Tradicionalmente, desde o direito romano a coisa julgada era vista como a exclusão da possibilidade de que fosse proposta uma nova demanda sobre a mesma res. $\mathrm{O}$ fundamento para essa vedação era encontrado no efeito consumptivo da litiscontestatio, que extinguia o direito de ação e impedia assim que ele fosse novamente exercitado.

\footnotetext{
${ }^{277}$ Cf. HEINITZ, Ernesto. Limitti oggettivi della cosa giudicata, cit., p. 88, PUGLIESE, Giovanni. Giudicato civile: diritto vigente, cit., p. 735 e REISCHL, Klaus. Die objektiven Grenzen der Rechtskraft im Zivilproze $\beta$, cit., p. 48-53. GIOVANNI PUGLIESE registra que, entre os romanistas, a tese de KELLER foi objeto de severas críticas, firmando-se o consenso de que os romanos conheciam tão somente o efeito consumptivo, ou negativo, da coisa julgada (Giudicato civile (storia). In: Enciclopedia del diritto. Milano: Giuffrè, 1969. v. 18, p. 735). A teoria encontrou grande ressonância e aceitação, contudo, no estudo da coisa julgada sob o direito moderno.
} 
Sob esta forma, a coisa julgada tem as feições de um pressuposto processual negativo, que exclui a possibilidade de um segundo julgamento do mérito e, por isso mesmo, impede que seja validamente instaurada outra relação processual com o mesmo objeto sobre o qual se decidiu na primeira oportunidade. O Código de Processo Civil trata da coisa julgada, sob o prisma do efeito negativo, em seu artigo 301, inciso VI, incluindo-a entre as questões prévias que o cumpre ao réu alegar, sob a forma de exceção, como matéria antecedente ao julgamento de mérito. A imutabilidade somente irá operar quando se reproduzir a mesma causa cujo mérito já tenha sido julgado em um processo anterior, remetendo o Código à tradicional regra dos três eadem para a finalidade da identificação das causas (art. $301, \S 2^{\circ}$, do Código de Processo Civil).

Se os elementos da ação não coincidirem, ainda que se aproximem, como em casos de conexão, por regra o processo poderá se instalar e se desenvolver regulamente, e inclusive ter seu mérito julgado por sentença (em que poderá se manifestar, eventualmente, a outra faceta da coisa julgada, que é a indiscutibilidade do que restou anteriormente decidido). Mas é necessário tomar em conta que a coisa julgada deve ser interpretada de modo substancial, pelo que - a despeito da restrição da fórmula utilizada pela lei - ela se estende para outras pretensões que, embora distintas, com ela tenham relações caracterizadas pela incompatibilidade, implicação ou inclusão. Esse aspecto do tema será examinado mais adiante, quando tratarmos do objeto da coisa julgada.

\subsubsection{Efeito ativo da coisa julgada}

A importância da contribuição de LUDWIG KELLER, ao descrever o efeito ativo da coisa julgada, esteve em perceber que a completa proteção da disciplina estabelecida pela sentença não seria alcançada tão somente pela idéia de consunção da actio. Isto porque a coisa julgada é instituto prático, que visa a assegurar estabilidade na fruição de um bem da vida, ou seja, uma utilidade material que foi consubstanciada em uma pretensão processual reconhecida ou rejeitada por uma sentença de mérito.

Essa estabilidade, contudo, pode ser parcial ou integralmente despida de qualquer relevância prática se no futuro, em um processo distinto entre as mesmas partes, no qual se discutam questões dependentes do resultado do primeiro processo, o segundo juiz puder lhe dar interpretação distinta daquela que foi alcançada na primeira sentença. Para que se 
preserve a autoridade do julgamento não basta que a mesma pretensão não possa ser julgada uma segunda vez; é necessário que, toda vez em que ela se evidencie como pertinente ao contexto de uma segunda disputa entre as partes, o resultado do julgamento não possa ser novamente discutido. É necessário que os juízes de futuros processos entre as mesmas partes, seja qual for seu objeto, estejam vinculados e não possam desconhecer aquilo que ficou decidido pela sentença ${ }^{278}$. A indiscutibilidade, ou efeito ativo da coisa julgada, consiste precisamente nesse vínculo.

A situação em que o efeito ativo da coisa julgada se mostrará relevante é aquela em que existir um nexo de dependência e prejudicialidade entre o objeto das duas causas, ou seja: a questão que constituiu o mérito do primeiro processo deverá ser um dos elementos constitutivos da segunda pretensão deduzida em juízo ${ }^{279}$. Um exemplo constantemente citado desse tipo de relação é o da ação de reconhecimento de paternidade e a ação de alimentos fundada na relação de direito de família. Se houver coisa julgada entre as partes em um primeiro processo, negando a paternidade, o juiz do segundo processo não poderá adotar como pressuposto de sua decisão na ação de alimentos o entendimento de que autor e réu são pai e filho. Se lhe fosse dado agir de forma contrária, estaria ele a privar de utilidade prática o primeiro julgamento, convertendo-o em uma declaração vazia de interesse. E pouca seria a autoridade do Estado ao aplicar o direito pelos seus órgãos de jurisdição, se em um segundo processo a mesma questão pudesse ser objeto de um entendimento diverso.

\footnotetext{
${ }^{278}$ Segundo a formulação de JAIME GUASP, "la antigua y mera función negativa de la cosa juzgada: imposibilidad general de abrir nuevos procesos: non bis in idem, ha sido completada en los procesos modernos, por la llamada función positiva de la cosa juzgada, que lo impide es que en ningún nuevo proceso se decida de modo contrario a como antes fue fallado. De este modo, se afina y se potencia mucho más la eficacia jurídica procesal de una decisión, que pasa de un mero obstáculo o bloqueo tosco de las actuaciones judiciales futuras, con resultado contrario a la justicia muchas veces, a ser un factor fundamental que debe componer afirmativamente tales actuaciones" (Derecho procesal civil: introducción y parte general, cit., t. 1, p. 578-579). E de fato, como observa BOTELHO DE MESQUITA, em "seu aspecto prático mais relevante, a autoridade da coisa julgada consiste pois na indiscutibilidade do elemento declaratório da sentença transitada em julgado. A hipótese de simples reiteração de ação idêntica a outra já decidida por sentença transitada em julgado é extremamente remota e só se pode atribuir à ignorância ou má-fé" (A coisa julgada, cit., p. 13).

${ }^{279}$ Segundo ANDREA PROTO PISANI, pode-se falar então que a coisa julgada não exerce apenas eficácia direta sobre a relação jurídica que foi objeto do processo, mas também eficácia reflexa sobre outras relações jurídicas dela dependentes (Lezioni di diritto processuale civile, cit., p. 63).
} 


\subsubsection{A eficácia preclusiva da coisa julgada}

O instrumento técnico que sustenta o instituto da coisa julgada, tanto em seu aspecto ativo (indiscutibilidade), como em seu aspecto negativo (imutabilidade), é a preclusão das questões pertinentes à causa ${ }^{280}$. Tal preclusão abrange as questões que tenham sido efetivamente deduzidas no processo, bem como daquelas que embora pudessem ter sido discutidas, não foram levantadas pelas partes. Por tal razão a coisa julgada, diz a doutrina, cobre "o deduzido e o dedutível".

Nessa linha, o artigo 474 do Código de Processo Civil afirma que "passada em julgado a sentença de mérito, reputar-se-ão deduzidas e repelidas todas as alegações e defesas, que a parte poderia opor assim ao acolhimento como à rejeição do pedido". O texto da lei, no particular, não seguiu a melhor técnica, e deve ser objeto de algumas observações para que possa ser compreendido em seu exato alcance e sentido.

De início, há que se registrar uma crítica à fórmula utilizada: não se trata de "reputar deduzidas e repelidas" questões que não foram discutidas no processo, expressão que remete à idéia de ficção de julgamento, ou de julgamento implícito, com o qual a doutrina buscava explicar a imutabilidade e a indiscutibilidade da sentença transitada em julgado $^{281}$. A eficácia preclusiva não chega a tanto, pela simples razão de que o expediente é desnecessário para assegurar estabilidade à decisão. Os fundamentos da sentença, a que se dirige a preclusão, em nenhuma hipótese integram a coisa julgada. As alegações de fato e de direito têm natureza apenas instrumental no processo: sua função é a de formar o raciocínio do juiz, auxiliando na construção lógica da decisão de mérito, mas é apenas esta última adquire relevância externa para processos futuros.

\footnotetext{
${ }^{280}$ Já identificando na eficácia preclusiva a técnica que possibilita a estabilidade da coisa julgada, CHIOVENDA escrevia em suas Instituições que "a coisa julgada é um bem da vida reconhecido ou negado pelo juiz; a preclusão de questões é o expediente de que se serve o direito para garantir o vencedor no gozo do resultado do processo" (Instituições de direito processual civil, cit., v. 1, p. 374).

${ }^{281}$ Essa mesma crítica é levantada por BARBOSA MOREIRA: “Todavia, embora denote considerável progresso em confronto com o texto anterior, a técnica do novo código, no particular, ainda se mantém presa à inútil ficção do 'julgamento implícito'. Trata-se menos, com efeito, de 'reputar deduzidas e repelidas' as 'alegações e defesas' capazes de influir no resultado do processo do que de proibir que tais 'alegações e defesas', deduzidas ou não, se venham a usar como instrumentos de ataque àquele resultado." (A eficácia preclusiva da coisa julgada material no sistema do processo civil brasileiro. In: . Temas de direito processual: $1^{\mathrm{a}}$ série. 2. ed. São Paulo: Saraiva, 1988. p. 102). Sobre a inadmissibilidade do julgamento implícito, ainda que no curso do processo, confira-se também ALLORIO, Enrico. Critica alla teoria del giudicato implicito. Rivista di Diritto Processuale, Padova, v. 13, n. 2, 1938.
} 
Se os argumentos efetivamente discutidos não integram o julgado, portanto, com muito mais razão não haveria porque elevar a tal condição os argumentos que por omissão das partes deixaram de ser discutidos. A preclusão explica o fenômeno de modo satisfatório, e não há porque se recorrer à idéia de julgado implícito. Aliás, o raciocínio é mesmo perigoso: não se mostraria compatível com a garantia do devido processo legal que exige o procedimento em contraditório como fonte de legitimação dos provimentos estatais de jurisdição - que a lei processual pudesse admitir julgamentos virtuais, fictícios, em prejuízo de qualquer indivíduo.

Na realidade, o sentido da norma deve ser buscado na vinculação dessa proibição de serem deduzidas novas alegações ou defesas à finalidade de se evitar uma segunda apreciação do pedido acolhido ou rejeitado. Com isso, resta bem delineado pelo texto da lei que aquilo se torna firme pela coisa julgada é o acolhimento ou a rejeição do pedido; e que apenas para assegurar a estabilidade desse juízo conclusivo de mérito é que a lei, como medida de apoio, exclui a possibilidade de deduzir novas alegações que busquem infirmar o decidido.

Tal exclusão de argumentos alternativos ${ }^{282}$, que é a substância da chamada eficácia preclusiva, não é mais do que um expediente prático sem o qual não se poderia falar em coisa julgada ${ }^{283}$. Pois é certo que se as partes pudessem a qualquer tempo reabrir a qualquer tempo a discussão em torno da justiça da decisão, sob um ângulo não apreciado no processo - e sempre haverá vários deles, relevantes ou não, que não foram levados em consideração no momento de decidir - a estabilidade desejada pela coisa julgada jamais seria alcançada, e o instituto teria um alcance tão limitado que seu valor seria mínimo para o direito processual.

\footnotetext{
${ }^{282}$ JOÃO DE CASTRO MENDES se vale da fórmula "exclusão de alternativas" para remeter à idéia de preclusão. Essa terminologia se justifica na medida em que "a atribuição dessa característica de indiscutibilidade destina-se à resolução de uma situação de incerteza. Tal resolução, como se tem dito, traduz-se na exclusão de afirmações alternativas: entre todas, o tribunal fixa-se numa e a ela atribui a característica de conteúdo ou de suporte primário do caso julgado" (Limites objectivos do caso julgado em processo civil, cit., p. 281).

${ }^{283}$ A fim de justificar a necessidade da preclusão de questões, BARBOSA MOREIRA expõe que "perfeitamente se concebe, em tese, que depois de findo o processo se viesse a pôr em dúvida o resultado atingido, acenando-se com tal ou qual questão que haja ficado na sombra e que, se porventura trazida à luz, teria sido capaz de levar o órgão judicial a conclusão diferente da corporificada na sentença”. Nessa hipótese, "sem dificuldade se entende, porém, que admitir a reabertura da discussão judicial, só porque alegue o interessado ter razões ainda não apreciadas, seria reduzir a bem pouco a garantia da coisa julgada, frustrando em larga medida a finalidade prática do instituto." (A eficácia preclusiva da coisa julgada material no sistema do processo civil brasileiro, cit., p. 98-99). Por isso, BOTELHO DE MESQUITA - que utilizava terminologia diversa ("imutabilidade da motivação"), escrevendo ainda sob o Código de 1939 afirma que "a imutabilidade da motivação se distingue da imutabilidade do dispositivo por ser de natureza meramente instrumental. A primeira é subordinada à segunda, que dela se utiliza como meio para sua realização na prática" (A autoridade da coisa julgada e a imutabilidade da motivação da sentença, cit., p. 143).
} 
A subordinação da eficácia preclusiva à finalidade de assegurar a estabilidade da decisão tem uma conseqüência da maior importância: ela em nada amplia os limites objetivos da coisa julgada ${ }^{284}$, em cujas fronteiras se mantém circunscrita a regra da preclusão. Assim, os mesmos fatos e argumentos rejeitados no primeiro processo podem ser novamente deduzidos em juízo como fundamento ou defesa, como elementos lógicos da decisão que não são alcançados pela coisa julgada, desde que se esteja diante de pretensão distinta, caracterizada por outro pedido ou por outra causa de pedir. Isto significa que se não estiver em jogo o resultado prático da sentença protegida pela coisa julgada, o instrumento em que ela se apóia não se faz necessário e, por isso, não haverá preclusão alguma que impeça a rediscussão de questões de fato ou direito resolvidas pela sentença transitada em julgado de um processo anterior.

\subsubsection{A "coisa julgada inconstitucional"}

Nos últimos anos, a partir da influência de ensaio do constitucionalista português PAULO OTERO ${ }^{285}$, a doutrina brasileira passou a discutir a possibilidade de se afastar a estabilidade da sentença de mérito transitada em julgado, quando seus fundamentos hajam sido, de alguma forma, incompatíveis com norma constitucional e tenham dessa forma provocado grave injustiça no julgamento. Defendendo essa tese, escreveram

\footnotetext{
${ }^{284}$ Como a coisa julgada não tem o efeito de exclusão sobre outras demandas conexas, e como a preclusão de questões é mero instrumento técnico para assegurar a estabilidade da res judicata, segue a conclusão de que ela não pode em nenhuma hipótese operar para fora dos limites objetivos da coisa julgada. Assim, "a preclusão das questões logicamente subordinantes apenas prevalece nos feitos onde a lide seja a mesma já decidida ou tenha solução dependente da que se deu à lide já decidida. Fora dessas raias, ficam abertas à livre discussão e apreciação as mencionadas questões, independentemente da circunstância de havê-las de fato examinado, ou não, o primeiro juiz, ao assentar as premissas de sua conclusão." (BARBOSA MOREIRA, José Carlos. A eficácia preclusiva da coisa julgada material no sistema do processo civil brasileiro, cit., p. 102). Não assiste razão, portanto, a GUSTAVO FILIPE BARBOSA GARCIA quando afirma que "a importância da eficácia preclusiva da coisa julgada acentua-se quando fatos (principais) e fundamentos jurídicos diferentes, aptos a formarem causa petendi, sejam alegados em nova demanda, entre as mesmas partes e com o mesmo pedido de ação anterior, cuja sentença de mérito transitou em julgado. Diante da inexistência de tríplice identidade de elementos, pode parecer inexistir o efeito negativo da coisa julgada, o que possibilitaria a decisão meritória desta segunda demanda. Mesmo assim, caso tais alegações fáticas e jurídicas pudessem ter sido opostas pelo demandante, no processo anterior, para o acolhimento da pretensão, preclusa estará a possibilidade de apresentá-las em processo posterior". (Coisa julgada: novos enfoques no direito processual, na jurisdição metaindividual e nos dissídios coletivos. São Paulo: Método, 2007, p. 28-29).

${ }^{285}$ Partindo de regra do art. $3^{\circ}$ da Constituição portuguesa de 1976 , que condiciona a validade dos atos do poder público à sua conformidade com o texto constitucional ("A validade das leis e dos demais actos do Estado, das regiões autónomas, do poder local e de quaisquer outras entidades públicas depende da sua conformidade com a Constituição"), PAULO OTERO defende "a possibilidade de interposição de um recurso extraordinário atípico de todas as decisões directa e imediatamente inconstitucionais, sempre que se tenham esgotado os respectivos recursos ordinários" (Ensaio sobre o caso julgado inconstitucional. Lisboa: Lex, 1993. p. 121).
} 
processualistas de destaque como CÂNDIDO RANGEl DinAmarco ${ }^{286}$, Humberto THEODORO Junior (em co-autoria com JULIANA CORDEIRo DE FARIA) ${ }^{287}$, TEREZA WAmbier e José Miguel MedinA ${ }^{288}$, com fundamentos heterogêneos, é verdade, mas convergindo para a conclusão de que em casos excepcionais seria possível desconsiderar o julgado. Para isso, se sustenta em linhas gerais que a garantia constitucional da proteção à coisa julgada é dirigida apenas ao legislador e não aos juízes ${ }^{289}$, e que a sua proteção no plano infraconstitucional decorreria de um princípio que deve ser sopesado caso a caso com outros valores conflitantes ${ }^{290}$.

Na realidade, a idéia de que graves vícios na sentença não permitiriam a formação da coisa julgada não é nova; no período do direito comum medieval, em que vigia a concepção da coisa julgada como ficção de verdade, a sentença nula era considerada inexistente e incapaz de fazer coisa julgada ${ }^{291}$. Essa concepção, no entanto, foi há muito tempo superada, desde que a coisa julgada se firmou como função pública de finalidades práticas: as nulidades se converteram em motivos de impugnação, tornaram-se sujeitas a preclusões e passaram a ser definitivamente sanadas com o trânsito em julgado. Perderam assim elas qualquer valor externo, juntamente com o restante do material lógico que leva à formação do dispositivo do julgamento. Ignorando esses desenvolvimentos, a doutrina da relativização representa um ataque direto ao núcleo essencial da coisa julgada no direito moderno. Por isso, denunciando os perigos e o retrocesso ínsito dessa tendência de relativização, levantaram-se as vozes autorizadas dos processualistas que mais se aprofundaram na teoria da coisa julgada em nosso país, como OvíDIo BAPTISTA DA SILVA, BARbosa Moreira e JosÉ IGNÁcio BotelHo de MESQuita, entre outros ${ }^{292}$.

\footnotetext{
${ }^{286}$ DINAMARCO, Cândido Rangel. Relativizar a coisa julgada material. Revista Forense, Rio de Janeiro, v. 358, n. 97, nov./dez. 2001, sob o mote de que "o processo deve ser realizado e produzir resultados estáveis tão logo quanto possível, sem que com isso se impeça ou prejudique a justiça dos resultados que ele produzirá".

${ }^{287}$ THEODORO JÚNIOR, Humberto; FARIA, Juliana Cordeiro de. A coisa julgada inconstitucional e os instrumentos processuais para seu controle. Revista dos Tribunais, São Paulo, n. 795, jan. 2002.

${ }^{288}$ WAMBIER, Teresa Arruda Alvim; MEDINA, José Miguel. O dogma da coisa julgada: hipóteses de relativização, cit., p. 39-78.

${ }^{289}$ Trata-se da interpretação literal e reducionista do art. $5^{\circ}$, inc. XXXVI da Constituição, segundo o qual "a lei não prejudicará o direito adquirido, o ato jurídico perfeito e a coisa julgada".

${ }^{290}$ Essa vertente, que a partir de uma argumentação mais sofisticada sugere uma "relativização" e não simples "desconsideração" da coisa julgada, foi explorada principalmente por DINAMARCO, no já mencionado ensaio Relativizar a coisa julgada material, cit.

${ }^{291}$ No direito lusitano, por exemplo, previa o título LXXV do Livro III das Ordenações Filipinas que "a sentença, que he per direito nenhuma, nunca em tempo algum passa em cousa julgada, mas em todo o tempo se pode oppor contra ella, que he nenhuma e de nenhum effeito, e portanto não he necessario ser della apellado".

${ }^{292}$ SILVA, Ovídio Baptista. Coisa julgada relativa? Revista dos Tribunais, São Paulo, v. 93, n. 821, p. 29-38, mar. 2004; BARBOSA MOREIRA, José Carlos. Considerações sobre a chamada "relativização" da coisa julgada material. Revista Síntese de Direito Civil e Processual Civil, Porto Alegre, v. 6, n. 33, p. 5-28,
} 
Como se pode perceber, a construção busca excepcionar a regra da eficácia preclusiva da coisa julgada, permitindo que os fundamentos deduzidos ou dedutíveis, desde que de natureza constitucional, sejam invocados para se discutir novamente a justiça da decisão. Para isso, essa corrente doutrinária tem necessariamente de contornar o fato de que a coisa julgada foi consagrada como garantia constitucional, o que se busca por dois argumentos: o de que a garantia se dirige apenas contra o legislador, o que facultaria a um juiz rediscutir a causa; ou o de que a coisa julgada não é uma garantia, mas um princípio que deve ser ponderado frente a outros valores da constituição. E desde logo se deve observar que, na medida em que atualmente se reconhece a penetração do direito constitucional em todos os demais ramos do direito, e considerando também que suas normas apresentam conteúdo aberto a um largo espectro de interpretações que é informado por critérios muitas vezes subjetivos, essa "excepcional" relativização pode se tornar freqüente a ponto de se converter em regra.

Não é nosso propósito aqui discutir em profundidade a tese da relativização da coisa julgada inconstitucional, tema complexo que estaria além do permitido pelas limitações de tempo e espaço deste trabalho. Como estamos descrevendo a disciplina da coisa julgada de um ponto de vista dogmático, nos limitamos a apontar o mecanismo pelo qual ela opera, que é a atenuação ou eliminação da eficácia preclusiva prevista pelo artigo 474 do Código de Processo Civil.

Tendo sido demonstrado que esse é o pilar sobre o qual se sustentam a imutabilidade e a indiscutibilidade, e bem assim a amplitude que a relativização pode atingir, o apontamento visa a demonstrar que a aceitação ampla da tese pode representar uma fragilização significativa da estabilidade proporcionada pela coisa julgada. A observação que se pode desde logo fazer é que a tese representa uma perigosa revalorização do elemento lógico da sentença, atenuando a finalidade prática que a jurisdição assumiu no Estado moderno, e trazendo assim de volta o risco, bem conhecido pelo processo comum medieval, da eternização dos litígios na busca da decisão que mais se aproxime à verdade, ou no caso, da "justiça" tal como vista por aquele que foi vencido na primeira demanda. Com isso se tem o sacrifício de um bem que o direito pode assegurar - a segurança representada pela coisa julgada - em troca de uma pretensão provavelmente

jan./fev. 2005; BOTELHO DE MESQUITA, José Ignácio. Conflito entre a intangibilidade da coisa julgada e outro princípio constitucional: um falso problema. In: A coisa julgada. Rio de Janeiro: Forense, 2006. São dignos de nota, ainda, a sólida tese de EDUARDO TALAMINI (Coisa julgada e sua revisão. São Paulo: Ed. Revista dos Tribunais, 2005) e o já citado ensaio de LUIZ GUILHERME MARINONI (Coisa julgada inconstitucional, cit.). 
inatingível, que é a eliminação da possibilidade do erro no exercício da jurisdição ${ }^{293}$. Se o diagnóstico, por outro lado, é que esses erros tenham se tornado tão graves e freqüentes a ponto de colocar em xeque o instituto da coisa julgada, melhor seria adotar regras, claras e conhecidas por todos de antemão, tais como o aumento do prazo para a rescisão do julgado sugerido por WALTER PIVA RODRIGUES ${ }^{294}$. Ou seja, o conflito de princípios entre segurança e justiça deveria ser reequilibrado pelo legislador segundo uma diferente regra, de conteúdo mais adequado a uma realidade social modificada, caso se faça o juízo político de que é este mesmo o caso.

Ao fim e ao cabo, o maior risco gerado pela doutrina aqui exposta é o afastamento casuístico da estabilidade da sentença, o que depõe não apenas contra a segurança, mas também contra a igualdade de tratamento dos cidadãos pela Justiça de seu país, com as gravíssimas implicações políticas a que esse tratamento seletivo abre as portas. Ao contrário do defendido por parte da doutrina relativista, a proteção à coisa julgada não é um princípio e não se dirige apenas contra o legislador ${ }^{295}$ : ultrapassado o prazo da ação rescisória, que é o meio predisposto pela lei para o balanceamento entre a segurança e outros valores especialmente caros ao ordenamento, passa a constituir ela uma regra jurídica e uma garantia constitucional do indivíduo, um direito fundamental de conteúdo negativo que impõe a abstenção de qualquer conduta estatal que a coloque em risco ${ }^{296}$. Por

\footnotetext{
${ }^{293}$ Com acuidade, observa OVÍDIO BAPTISTA DA SILVA que, sendo permitido a uma sentença judicial declarar a injustiça de outra precedente, nada a coloca a salvo de futuramente sofrer o mesmo questionamento, em um ciclo que perpetuaria o conflito: “a 'injustiça da sentença' nunca foi e, a meu ver, jamais poderá ser, fundamento para afastar o império da coisa julgada. De todos os argumentos concebidos pela doutrina, através dos séculos, para sustentar a necessidade de que os litígios não se eternizem, parece-me que o mais consistente reside, justamente, na eventualidade de que a própria sentença que houver reformado a anterior, sob o pressuposto de conter injustiça, venha a ser mais uma vez questionada como injusta; e assim ad aeternum, sabido, como é, que a justiça, não sendo um valor absoluto, pode variar, não apenas no tempo, mas entre pessoas ligadas a diferentes crenças políticas, morais e religiosas, numa sociedade democrática que se vangloria de ser tolerante e 'pluralista' quanto a valores". (Coisa julgada relativa?, cit., p. 36).

${ }^{294}$ PIVA RODRIGUES, Walter. Coisa julgada tributária, cit., p. 122. No mesmo sentido, SÉRGIO GILBERTO PORTO (Coisa julgada civil, cit., p. 125-138).

${ }^{295}$ BOTELHO DE MESQUITA levanta um interessante argumento para afastar a interpretação restritiva da garantia constitucional da coisa julgada. Diz ele que "a liberdade conferida ao legislador ordinário para ampliar, restringir ou abolir a coisa julgada incluiria a liberdade de tornar ineficaz o preceito do art. $5^{\circ}$, XXXVI na parte em que alude à intangibilidade da coisa julgada. De fato, abolida a coisa julgada por lei ordinária, deixaria de haver coisa julgada que pudesse desfrutar da intangibilidade constitucional. $\mathrm{O}$ preceito cairia no vazio, por obra e graça da lei ordinária, invertendo-se a hierarquia das normas jurídicas". (Conflito entre a intangibilidade da coisa julgada e outro princípio constitucional: um falso problema, cit., p. 100). Em suma, a fórmula da Constituição, ao vedar ao legislador a modificação da coisa julgada, pressupõe logicamente essa garantia individual frente aos demais poderes do Estado.

${ }^{296} \mathrm{~A}$ diferença entre princípios e regras, segundo a teoria de RONALD DWORKIN, está na estrutura da norma jurídica. Enquanto as regras estipulam uma conseqüência jurídica determinada, a ser aplicada de uma maneira "tudo ou nada", os princípios são normas que habitualmente se interseccionam, hipótese em que é necessário aferir o peso relativo de um frente ao outro mediante uma operação de balanceamento. Enquanto a incompatibilidade entre duas regras implica a invalidade de uma delas perante o ordenamento,
} 
isso, não nos parece ter sido acertado o recente posicionamento adotado pelo Supremo Tribunal Federal ao julgar o recurso extraordinário $\mathrm{n}^{\mathrm{o}} 363.889$, ocasião em que a corte constitucional deu à regra da coisa julgada o tratamento próprio dos princípios e admitiu sua ponderação frente a valores protegidos pela Constituição, afastando-a no caso concreto de investigação de paternidade em que não havia sido produzida a prova técnica de DNA ${ }^{297}$.

Para além das pretensões de desconsideração da coisa julgada mediante alegação de grave injustiça praticada em casos concretos, há que se tomar em exame também a hipótese de desconsideração genérica da coisa julgada. Esse fenômeno ingressou em nosso direito processual sob a roupagem da inexigibilidade do título judicial incompatível com o entendimento firmado pelo Supremo Tribunal Federal em controle de constitucionalidade, por efeito das regras dos arts. 475-L, $\$ 1^{\circ}$, e 741, parágrafo único, do Código de Processo Civil (introduzidas pela Lei n. 11.232/2005). Ambos os artigos veiculam o seguinte texto: "considera-se também inexigível o título judicial fundado em lei ou ato normativo declarados inconstitucionais pelo Supremo Tribunal Federal, ou fundado em aplicação ou interpretação da lei ou ato normativo tidas pelo Supremo Tribunal Federal como incompatíveis com a Constituição Federal". Nesse caso, a ofensa à garantia da coisa julgada presente no art. $5^{\circ}$, inc. XXXVI, da Constituição de 1988 parece evidente. Isto porque, ainda que se queira interpretar a regra no sentido de que se veda apenas ao legislador desconsiderar a coisa julgada, é certo que o entendimento firmado pelo Supremo Tribunal Federal acerca da inconstitucionalidade das leis, em razão dos atributos de generalidade $e$ abstração que lhe são peculiares298, se apresenta como ela própria como uma nova lei em sentido substancial e, portanto, certamente incide na proibição constitucional.

os princípios conflitantes podem conviver no ordenamento como normas igualmente válidas (Taking rights seriously, cit., especialmente p. 22-28).

${ }^{297}$ Rel. Min. DIAS TOFFOLI, Plenário, maioria, j. 02.06.2011, p. DJe 16.12.2011.

${ }^{298}$ Trata-se da concepção de que ao declarar a inconstitucionalidade das leis, substancialmente, a Corte Constitucional age como legislador negativo e contra-majoritário. "When the Supreme Court declares unconstitutional a legislative act or the action of an elected executive, it thwarts the will of representatives of the actual people here and now; it exercises control, not on behalf of the prevailing majority, but against it. That, without mystic overtones, is what actually happens" (BICKEL, Alexander. The least dangerous branch. 2. ed. Yale University Press: New Haven and London, 1986. p. 17). Comentando o mesmo dispositivo e sua "facilidade autoritária", LUIZ GUILHERME MARINONI afirma tratar-se "não apenas de mecanismo que viola a garantia da coisa julgada material, porém, mais precisamente, de um gigantesco aparato repressivo voltado à nulificação de todo e qualquer juízo (legítimo) de constitucionalidade que não esteja de acordo com o pronunciamento ulterior do Supremo Tribunal Federal" (Coisa julgada inconstitucional, cit., p. 130). 


\subsection{Amplitude objetiva da coisa julgada}

\subsubsection{Limitação à lide e às questões decididas}

O objeto da coisa julgada deve corresponder ao objeto do que foi substancialmente decidido pela sentença. Nesse sentido, ao estabelecer amplitude da coisa julgada no direito brasileiro, o artigo 468 do Código de Processo Civil dispõe que "a sentença, que julgar total ou parcialmente a lide, tem força de lei nos limites da lide e das questões decididas". A regra reproduziu quase que fielmente o caput do artigo 287 do Código de Processo Civil de 1939, com uma importante e decisiva alteração: a circunscrição do julgado à lide.

O conceito de lide, muito embora tenha contornos por vezes imprecisos em razão de sua inerente complexidade ${ }^{299}$, constitui um dos elementos centrais da codificação de $1973^{300}$. Devemos atentar para que o Código de Processo Civil, evitando a concepção "sociológica" de CARNELUTTI, adotou um conceito formal da lide, que se traduz no conflito

${ }^{299} \mathrm{O}$ conceito de lide foi desenvolvido por CARNELUTTI, que a definiu - em linhas gerais, já que o conceito variou ao longo de sua obra - como o conflito de interesses caracterizado por uma pretensão resistida. A polêmica em torno do conceito de lide se deveu ao fato de que na sua concepção original se tratava de fenômeno externo ao processo, que nele poderia ser parcial ou totalmente introduzido, segundo a vontade das partes. PIERO CALAMANDREI dirigiu severa crítica ao conceito, que considerava inútil do ponto de vista científico, na medida em que os elementos externos ao processo nunca poderiam ser totalmente apreendidos ou considerados para qualquer finalidade. O sentido que a palavra lide assume, no Código de Processo Civil, é aquele que LIEBMAN lhe emprestou: "pedido e contestação representam os pedidos em conflito e a função do juiz consiste, justamente, em julgar qual dos dois é conforme ao direito, concedendo ou negando, em conseqüência, a medida requerida pelo autor. Esse conflito de pedidos forma a matéria lógica do processo e o elemento formal de seu objeto, ao passo que o conflito de interesses, na medida em que foi deduzido em juízo, representa seu substrato material. Este conflito de interesses, qualificado pelos pedidos correspondentes, representa a lide, ou seja o mérito da causa. A lide é aquele conflito, depois de moldado pelas partes, e vazado nos pedidos formulados ao juiz" (LIEBMAN, Enrico Tullio. O despacho saneador e o julgamento do mérito. In: _. Estudos sobre o processo civil brasileiro. 2. ed. São Paulo: Bushatsky, 1976. p. 121).

${ }^{300} \mathrm{~A}$ exposição de motivos elaborada pelo então Ministro da Justiça ALFREDO BUZAID para o projeto do Código de Processo Civil de 1973 afirma que a lide tem o sentido de mérito, de modo que no vocábulo não deve ser compreendido nenhum dado externo ao processo: "o projeto só usa a palavra "lide" para designar o mérito da causa. Lide é, consoante a lição de Carnelutti, o conflito de interesses qualificado pela pretensão de um dos litigantes e pela resistência do outro. O julgamento desse conflito de pretensões, mediante o qual o juiz, acolhendo ou rejeitando o pedido, dá razão a uma das partes e nega-a à outra, constitui uma sentença definitiva de mérito. A lide é, portanto, o objeto principal do processo e nela se exprimem as aspirações em conflito de ambos os litigantes". CÂNDIDO RANGEL DINAMARCO obtempera essa afirmação com a observação de que "a identificação entre lide e mérito jamais foi feita assim, em termos tão claros e radicais, pelo próprio Carnelutti. È notório que este conceitua o mérito a partir da lide, mas não diz que ele seja a lide.” (O conceito de mérito em processo civil. In: Fundamentos do processo civil moderno. 6. ed. São Paulo: Malheiros Ed., 2010. v. 1, p. 320). De fato, a relação que se estabelece entre o processo e a lide, para CARNELUTTI, é de continente e conteúdo, ponto que é afirmado em diversos momentos de sua obra. A lide penetra no processo, integral ou parcialmente, de acordo com a demanda proposta pelo autor (Lite e processo. In: Studi di processo civile. Padova: Cedam, 1939. v. 3). Por isso, não há como se estabelecer uma correspondência necessária entre os conceitos, em seu pensamento. O texto da Exposição de Motivos de BUZAID parece incorporar, em razão dessas observações, o conceito formal de lide proposto por LIEBMAN (vide nota supra). 
de interesses caracterizado por uma pretensão resistida, não da maneira como experimentado na realidade da vida, mas tal como representado no processo pela demanda do autor e pela resposta do réu. Ela corresponde à idéia de objeto do processo, o Streitgegestand da doutrina alemã, que nada mais representa do que o mérito da causa em cujas fronteiras se desenvolvem o contraditório e a cognição. Dessa forma, "apenas a lide é julgada; e, como a lide se submete à apreciação do órgão judicial por meio do pedido, não podendo ele decidi-la senão 'nos limites em que foi proposta' (art. 128), segue-se que a área sujeita à autoridade da coisa julgada não pode jamais exceder os contornos do petitum ${ }^{\text {,301 }}$.

A identificação do objeto do processo com a lide, isto é, com a contraposição de interesses entre as partes em torno da fruição de um bem da vida, tal como levada ao processo pelas partes, revela a complexidade do conceito de objeto do processo $^{302}$, e é de especial importância para justificar aquilo que JOÃO DE CASTRO MENDES chamou de casos de extensão da coisa julgada por motivos de coerência lógica jurídica ou por motivos de coerência prática. Como bem observa em sua monografia sobre os limites objetivos do caso julgado em processo civil, a coisa julgada não se limita estritamente pelos elementos formais de identificação da ação, mas se estende para impedir a discussão de demanda em sentido inverso, por incompatibilidade; ou para impedir que sejam discutidas demandas incluídas ou implicadas naquela que foi objeto da decisão.

Assim, se a sentença houver concluído que o réu deve uma quantia certa ao autor, a coisa julgada impedirá a propositura de demanda inversa que vise à declaração de inexistência do crédito (incompatibilidade), ou a que vise à declaração de que o crédito consiste em uma prestação inferior (inclusão) ou diversa (implicação) daquela que se decidiu caber ao autor. De igual maneira, a coisa julgada também tem o efeito de vedar nova decisão que se coloque como obstáculo prático ao resultado do processo, ainda que os elementos de identificação da ação não $\operatorname{coincidam}^{303}$ : assim, por exemplo, seria obstado pela coisa julgada o interdito proibitório ajuizado pelo proprietário, previamente derrotado na ação confessória em que se instituiu servidão de passagem. O que se observa, de todas essas hipóteses, é que a amplitude da coisa julgada não se determina exclusivamente por

\footnotetext{
${ }^{301}$ BARBOSA MOREIRA, José Carlos. Os limites objetivos da coisa julgada no sistema do novo Código de Processo Civil. In: Temas de direito processual: $1^{\text {a }}$ série. 2. ed. São Paulo: Saraiva, 1988. p. 91.

${ }^{302}$ CHIOVENDA, Giuseppe. Instituições de direito processual civil, cit., v. 1, p. 357.

${ }^{303}$ MENDES, João de Castro. Limites objectivos do caso julgado em processo civil, cit., p. 330-348. Também entre nós, ARRUDA ALVIM chama atenção para o fato de que "a teoria das três identidades não pode, pois, ser entendida, literalmente, devendo-se fazer certas aparentes concessões, tendo em vista que o sistema jurídico define um objeto ("conseqüência jurídica') como equivalente ao outro". (Manual de direito processual civil, cit., p. 440).
} 
critérios formais, mas principalmente pela finalidade de assegurar o resultado prático de impedir que um bem da vida reconhecido ao autor seja desconhecido ou negado em processos ulteriores, seja qual for o meio pelo qual se busque exercer essa intenção ${ }^{304}$. Dessa forma, a coisa julgada deve ser interpretada à vista dos casos concretos em que a autoridade sentença anterior possa estar em jogo ${ }^{305}$; há que se ter em vista sempre a finalidade prática do instituto. Embora o assunto seja rico em sutilezas, é grande a importância de serem assim estabelecidos os limites da coisa julgada, porque dificilmente o autor inconformado com uma coisa julgada anterior tentará a reiteração de uma demanda tal e qual foi julgada na primeira oportunidade: muito mais provável é que se busque um ataque indireto à sentença, com o objetivo de tolher suas conseqüências práticas. De igual maneira, a parte já vencida em um primeiro processo, certamente buscará fazer crer que uma segunda pretensão, conexa ao fundamento da primeira sentença, estará compreendida na eficácia preclusiva associada à coisa julgada, muito embora a rigor se tratem de pretensões diversas.

A idéia de que a coisa julgada se determina por aquilo que foi objeto de efetivo julgamento tem outras implicações, que convém deixar bem explicitadas. A primeira delas é que a coisa julgada, em nosso sistema, não tem eficácia de exclusão sobre outras pretensões conexas. Em outras palavras, no direito brasileiro a extensão da coisa julgada não vai a ponto de exercer efeitos limitativos ou excludentes de demandas autônomas derivadas da mesma causa de pedir. Se a conduta do réu for fundamento para que o autor peça a remoção do ilícito e a indenização dos prejuízos causados, por exemplo, o fato de ele ter movido apenas a primeira dessas duas pretensões isoladamente não impedirá que a segunda seja ajuizada, após o trânsito em julgado da sentença de mérito que declare a procedência ou improcedência da pretensão. O que lhe seria vedado seria deduzir uma

\footnotetext{
${ }^{304}$ A casuística do Superior Tribunal de Justiça apresenta julgado em que se afirma que, apesar de não coincidirem os elementos de identificação da ação, estando em curso ação de execução por benfeitorias feitas pelo autor em imóvel alheio, é vedado ao réu ajuizar nova demanda em que pretende lhe seja reconhecida a propriedade por usucapião desses mesmos bens, pois isso implicaria substancialmente na desconsideração do primeiro julgado. "Não pode o juiz, em ação distinta, proferir decisões que impliquem em verdadeira desconstituição ou desconhecimento da "res judicata"' (Superior Tribunal de Justiça, REsp 5.115/BA, rel. Min. ATHOS CARNEIRO, Quarta Turma, j. 28.05.1991, p. DJ 24.06.1991)

${ }^{305}$ Também EDUARDO TALAMINI sustenta a extensão da coisa julgada para além dos limites do objeto do processo, afirmando que: "Mais do que a identidade dos pedidos, estão abrangidos nos limites objetivos da coisa julgada: (i) o novo pedido que, embora não idêntico ao anterior já julgado, nele esteja contido (...); (ii) o pedido de um resultado que seja prática e objetivamente incompatível com o resultado estabelecido no decisum anterior (...); (iii) o pedido que esteja prejudicado pelo decisum de um processo anterior" (TALAMINI, Eduardo. Coisa julgada e sua revisão, cit., p. 70-71). Trata-se substancialmente, portanto, das mesmas hipóteses de extensão por motivos de coerência lógica ou jurídica identificados por JOÃO DE CASTRO MENDES.
} 
mesma pretensão de modo fracionado, ou seja, exigir o pagamento de uma indenização estimada em um valor certo e determinado em um primeiro processo, e voltar posteriormente a juízo para pedir a complementação da mesma obrigação. Isto é assim porque, como vimos anteriormente, o núcleo mínimo da demanda deve conter a integralidade da pretensão (item 3.1.2, supra).

Exemplo do efeito de exclusão da coisa julgada sobre demandas conexas se obtém pela regra do art. 400 da Ley de Enjuiciamento Civil $\mathrm{n}^{\circ}$ 01/2000 espanhola ${ }^{306}$, que impõe sob pena de preclusão para processos futuros - que todas as possíveis causas de pedir sejam deduzidas na demanda. Diante disso, e como foi percebido por ANDRÉS DE LA OLIVA SANTOS, para todos os efeitos práticos o processo passa a ter não apenas um "objeto real", composto pelo pedido e causa de pedir deduzidos em juiz, mas também um "objeto virtual" integrado pelas causas de pedir conexas que tenham sido omitidas ${ }^{307}$, sobre as quais também se estenderão os vínculos da coisa julgada e da litispendência. Trata-se de diretriz cuja compatibilidade com a idéia de inafastabilidade da jurisdição nos parece duvidosa, trazendo à vida a figura do julgado implícito que a doutrina tanto condenou no passado $^{308}$. É certo, assim, que a disciplina espanhola se distancia da regra do direito

\footnotetext{
${ }^{306}$ A regra constante do art. 400 da LEC 01/2000 é a seguinte: “Artículo 400. Preclusión de la alegación de hechos y fundamentos jurídicos. 1. Cuando lo que se pida en la demanda pueda fundarse en diferentes hechos o en distintos fundamentos o títulos jurídicos, habrán de aducirse en ella cuantos resulten conocidos o puedan invocarse al tiempo de interponerla, sin que sea admisible reservar su alegación para un proceso ulterior. La carga de la alegación a que se refiere el párrafo anterior se entenderá sin perjuicio de las alegaciones complementarias o de hechos nuevos o de nueva noticia permitidas en esta Ley en momentos posteriores a la demanda y a la contestación. 2. De conformidad con lo dispuesto en al apartado anterior, a efectos de litispendencia y de cosa juzgada, los hechos y los fundamentos jurídicos aducidos en un litigio se considerarán los mismos que los alegados en otro juicio anterior si hubiesen podido alegarse en éste." (grifos nossos)

307،Se propone aquí una dualidad que, a nuestro entender, viene abonada por la realidad de esos dos planos, mientras que, por el contrario, problemas relativos al objeto del proceso no se resolverán con construcciones conceptuales que no asuman esa realidad. Está, por un lado, lo que es objeto de un proceso, a los efectos de ese mismo proceso. Y, por otro, lo que vale como objeto procesal o ha de considerarse objeto de un proceso para resolver distintos problemas" (SANTOS, Andrés de la Oliva. Objeto del proceso y cosa juzgada en el proceso civil. Cizur Menor, Navarra: Thomson Civitas, 2005. p. 76 e ss., grifos nossos).

${ }^{308} \mathrm{Em}$ que nos pareça claro o retrocesso técnico da legislação espanhola, cabe aqui o registro de que HUMBERTO THEODORO JUNIOR publicou artigo elogioso a essa técnica que, nas próprias palavras do autor, visa a "abortar" processos ainda não nascidos, na esperança de que isso possa contribuir para a redução da litigiosidade (Redimensionamento da coisa julgada. Revista Síntese de Direito Civil e Processual Civil, Porto Alegre, n. 58, p. 63, mar./abr. 2009). Com a vênia devida ao respeitável professor, parece difícil enxergar como a simples recusa do Estado em solucionar uma pretensão autônoma - a que subjaz um conflito da vida concreta, como é recomendável nunca perder de vista - poderia contribuir para a redução da litigiosidade. A eventual impressão de pacificação assim gerada, em nosso modo de entender, pode ser comparada à aparente limpeza do cômodo cuja sujeira foi varrida para debaixo do tapete: ela é afastada de nossos olhos, mas permanece no ambiente, até que o seu inevitável acúmulo um dia não permita mais esconder o problema que nunca se tentou verdadeiramente solucionar. Como demonstra o professor RODOLFO DE CAMARGO MANCUSO, em recente tese, a pacificação social pode passar pela adoção de técnicas alternativas de solução de conflitos, inclusive a eventual remissão obrigatória a meios
} 
brasileiro, que limita a coisa julgada à lide efetivamente decidida (art. 468 do Código de Processo Civil).

Por outro lado, deve se considerar a circunstância de que aquilo que se torna coberto pela coisa julgada é o que foi decidido pela sentença, e não o que se pediu que fosse julgado quando da propositura da demanda. Assim, na eventualidade de incongruência entre o objeto da sentença e os limites objetivos da lide, como são os chamados julgamentos "extra petita" ou "infra petita" (art. 460, CPC), o que será coberto pela coisa julgada é o resultado da conclusão contida na sentença, e não as questões que foram submetidas a juízo pelas partes. Não se quer afirmar aqui que o juiz tenha liberdade para decidir aquilo que lhe aprouver. A lei processual determina que haja correspondência entre o objeto do processo e o objeto da sentença, pois a decisão deve se amoldar à discussão em contraditório desenvolvida entre as partes. Se a sentença julgar fora dos limites do pedido e de seu fundamento, concedendo ou negando ao autor coisa diversa da que foi pedida, ela será inválida e passível de anulação, inclusive de ofício, pois a correlação entre pedido e sentença é regra de ordem pública. Poderá ela ainda ser rescindida, dada a gravidade do vício. O que se quer sublinhar é que, tendo a sentença de mérito transitado em julgado apesar desses defeitos, por graves que sejam, a coisa julgada ainda assim se fixará sobre o que foi decidido, e os atos de postulação perderão toda importância para o futuro, em companhia do restante do material lógico que conduziu à decisão. Embora o natural seja que haja uma correspondência entre a res in iudicium deducta e a res judicata, pode ocorrer de haver incongruências entre uma e outra, e então o que terá relevância externa ao processo é apenas aquilo que foi julgado.

Entretanto, não poucas vezes a doutrina pretendeu buscar fora da sentença elementos que definissem os contornos da coisa julgada. CARnEluTTI, por exemplo, defendeu que omissão de pronúncia sobre algum dos pedidos teria o efeito de manter a litispendência, impedindo a repropositura da demanda, em um efeito semelhante ao da coisa julgada $^{309}$. Isto porque com o trânsito em julgado da sentença infra petita, ficaria

extrajudiciais mais aderentes à peculiaridade do conflito (A resolução dos conflitos e a função judicial no contemporâneo Estado de Direito. São Paulo: Ed. Revista dos Tribunais, 2009). O que a lei não pode fazer é simplesmente vedar o acesso à jurisdição e não oferecer meio algum para a solução dos conflitos conexos à primeira demanda.

${ }^{309} \mathrm{~A}$ impossibilidade de repropositura da demanda, para CARNELUTTI, não se deveria diretamente à coisa julgada, mas ao fato de que ela manteria estável o efeito de litispendência do processo parcialmente não julgado: “vi si opporrebbe l'ostaccolo della litispendenza, poichè l'effetto preclusivo della domanda precedente continua a valere fino a che sulla domanda stessa non si formi il giudicato, il quale, viceversa, è escluso dalla pronuncia mancata" (Casi clinici. Effetti della cassazione per omessa pronunzia. Rivista di Diritto Processuale, Padova, v. 15, p. 68-69, 1938). 
excluída definitivamente a possibilidade de renovação do processo, o que - na prática acaba por consagrar a indiscutibilidade do que não foi sequer julgado. Essa tese foi objeto da crítica certeira de CALvOSA, que demonstrou que ao proferir sentença definitiva, ainda que deficiente, o Estado cumpre sua obrigação e a litispendência se resolve ${ }^{310}$. De outro lado, a formação de coisa julgada exige um provimento concreto, ou seja, o efetivo julgamento da lide $\mathrm{l}^{311}$.

Assim como se pretendeu ver incluído na coisa julgada algo que não foi julgado por vício de incongruência da sentença, a doutrina também quis excluir de seu objeto pretensões que tenham sido objeto de julgamento expresso. Nesse sentido, TeRESA Wambier e José Miguel Medina manifestaram o entendimento de que as sentenças que decidam fora dos limites do pedido não podem se constituir em objeto da coisa julgada. Essa posição se funda no pressuposto de que o pedido seria pressuposto de existência da sentença $^{312}$, premissa esta que - com a devida vênia - nos parece ser inaceitável diante da regra do art. 460 do Cód. de Processo Civil, que trata a adstrição ao pedido como requisito formal do ato judicial; cujos requisitos essenciais, de outro lado, são enumerados no art. 458 desse diploma. Parece claro, assim, que na hipótese de julgamento extra ou citra petita, as partes têm o ônus de recorrer ou de ajuizar a ação rescisória, sob pena de verem convalidado um julgamento proferido fora dos limites da demanda, que lhes será

\footnotetext{
310“A coisa julgada formal" - diz FREDERICO MARQUES - "marca a prestação entregue pelo Estado, através da jurisdição" (Instituições de direito processual civil, cit., v. 4, p. 327). Assim sendo, má prestada ou deficiente que tenha sido a tutela jurisdicional, ela foi entregue pelo Estado: "decidendo parzialmente le questioni proposte al suo esame, con una sentenza che, peraltro, vuol essere ed è definitiva, il giudice estingue il suo obbligo verso la parte, sia pure in maniera non completamente satisfattoria. La litispendenza cessa in quanto è stata pronunciata sentenza definitiva e la parte potrà ripropore lazione, relativamente alla domanda non deisa, sia avanti lo stesso giudice suia avanti altro giudice" (CALVOSA, Carlo. Omisione di pronuncia e cosa giudicata. Rivista di Diritto Processuale Civile, Padova, 1950. v. 5, p. 247-248. No mesmo sentido, WAMBIER, Teresa Arruda Alvim; MEDINA, José Miguel. O dogma da coisa julgada: hipóteses de relativização, cit., p. 83).

${ }^{311}$ De fato, CALVOSA parte do pressuposto de que "il provvedimento è condizione necessaria e indispensabile per la formazione della cosa giudicata" (Omisione di pronuncia e cosa giudicata, cit., $p$. 237), pelo que se torna inaceitável que ela dê eficácia panprocessual a uma preclusão interna do processo. Examinando o mesmo problema no direito espanhol, a que aludimos há pouco, MARIA TERESA PADURA BALLESTEROS conclui que sob o sistema da Ley de Enjuiciamiento Civil de 2000 não há, tampouco, coisa julgada. Entretanto, ficaria ainda assim excluída a possibilidade de novo ajuizamento da pretensão não julgada, por efeito da preclusão de causas conexas (Fundamentación de la sentencia, preclusión y cosa juzgada: su régimen en la LEC 1/2000. Valencia: Tirant lo Blanch, 2002. p. 53-63). Este nos parece mais um exemplo dos resultados imprevisíveis e indesejáveis do novo direito processual espanhol.

${ }^{312} \mathrm{~A}$ tese é assim formulada pelos seus autores: “(...) na hipótese de se ter decidido pedido que não tenha sido formulado, cremos que a solução se liga à idéia de que o que foi apreciado é que transita em julgado, desde que tenha sido pedido. (...) se o autor formula os pedidos $\mathrm{X}$ e $\mathrm{Y}$ e o juiz decide $\mathrm{X}, \mathrm{Y}$ e $\mathrm{Z}$, quanto a $\mathrm{Z}$ o que se terá é uma sentença inexistente, que, pois, não transita em julgado, já que não corresponde a pedido algum. (WAMBIER, Teresa Arruda Alvim; MEDINA, José Miguel. O dogma da coisa julgada: hipóteses de relativização, cit., p. 84-85). Anote-se aqui que, onde se lê "transitar em julgado", deve-se entender "fazer coisa julgada".
} 
plenamente oponível. Nesse sentido, BARBOSA MoreIRA é peremptório: "como em geral acontece com as nulidades da sentença, também esta, após o trânsito em julgado, se o vício não tiver sido corrigido se converte em mera rescindibilidade. Por conseguinte, não é possível, por exemplo, alegar em embargos a uma execução que a sentença exeqüenda é nula porque condenou além do pedido",313.

Em suma, a coisa julgada sempre abarca aquilo que foi efetivamente decidido, e não aquilo que deveria ter sido decidido, conforme princípio defendido, entre outros, por ERNESTO HEINITZ $^{314}$ e JOÃo DE CASTRO MENDES ${ }^{315}$. Por tal razão, seria um erro buscar os elementos para identificação da coisa julgada em atos externos à sentença, como a petição inicial ou a resposta do réu: é necessário recorrer à sua motivação, e nesse sentido é que se fala da importância dos fundamentos para determinar o alcance da coisa julgada ${ }^{316}$.

\subsubsection{O objeto do processo e seus elementos de identificação}

A identificação do campo de incidência da coisa julgada, em razão da sua vinculação à lide (art. 468 do Código de Processo Civil), se insere no delicado campo da identificação das ações e do objeto do processo. De início, deve-se atentar para que o

${ }^{313}$ BARBOSA MOREIRA, José Carlos. Correlação entre o pedido e a sentença. Revista de Processo, São Paulo, n. 83, jul./set. 1996.

${ }^{314}$ “Non v'è alcun dubbio in questo caso che i limiti del giudicato derivino dal contenuto effettivo della sentenza, non dal contenuto che la sentenza avrebbe dovuto avere, se non fosse caduta nel vizio ultra ed extra petita" (I limitti oggettivi del giudicato civile, p. 129)

${ }^{315}$ JOÃO DE CASTRO MENDES afirma que "se o caso julgado tem como conteúdo primário a afirmação judicial que forma o conteúdo da sentença, thema decisum, daqui decorre que em rigor não tem como conteúdo primário o objecto da ação ou do pedido, ou da defesa, ou do processo"; em lugar disso, “(...) o objecto da sentença é a versão oficial do objecto do processo, e a equiparação entre os dois objectos, transitada a mesma sentença (e sanados em princípio os seus vícios), torna-se indiscutível também. Transitada em julgado a sentença, entende-se juris et de jure que o efeito jurídico pretendido era o efeito jurídico que a sentença concedeu ou recursou". (Limites objectivos do caso julgado em processo civil, cit., p. 255 e 258 , g.n.).

${ }^{316}$ Nesse sentido, LIEBMAN chama a atenção para o fato de que o dispositivo da sentença deve ser entendido "em sentido substancial, e não apenas formalístico, de modo que compreenda não apenas a frase final da sentença, mas também tudo o quanto o juiz haja porventura considerado e resolvido do pedido feito pelas partes. Os motivos são, pois, excluídos, por essa razão da coisa julgada, mas constituem amiúde indispensável elemento para determinar com exatidão o significado e alcance do dispositivo" (LIEBMAN, Enrico Tullio. Limites objetivos da coisa julgada. In: Estudos sobre o processo civil brasileiro. 2. ed. São Paulo: Bushatsky, 1976. p. 164. Em igual sentido, chamando atenção para a "complexidade" do conceito de bem da vida, CHIOVENDA, Giuseppe. Instituições de direito processual civil, cit., v. 1, p. 410). E EDUARDO COUTURE observa que nas sentenças de improcedência, que não irradiam quaisquer efeitos, somente a partir dos fundamentos é possível conhecer o conteúdo da cosia julgada: "hasta deve admitirse que la necesidad de acudir a los motivos es absoluta en ciertas circunstancias. Así, por ejemplo, en las sentencias que absuelven pura y simplesmente de la demanda, nunca será posible determinar el alcance exacto de la cosa juzgada, y, en especial, el objeto y la causa petendi, sin acudir a la motivación de la sentencia" (Fundamentos del derecho procesal civil, cit., p. 349). 
objeto do processo não se confunde com o mais amplo objeto de cognição do juiz ${ }^{317}$, que envolve todos os pontos e questões por que deverá passar o juiz ao preparar sua decisão. Objeto do processo significa o bem da vida pretendido, sobre o qual versa o pedido de tutela jurisdicional e em cujos limites se exerce a jurisdição. O núcleo da coisa julgada corresponde assim ao mérito da causa. Se a coisa julgada viesse a assumir uma extensão mais ampla do que a do objeto do processo, isto se deveria a algum artifício criado pela lei, destinado especificamente a ampliar os seus limites naturais.

Ainda no período medieval, foi concebido pelos glosadores o critério de identificação da ação consistente no chamado tria eadem: partes, pedido e causa de pedir, que o Código de Processo Civil estabelece como parâmetro para distinguir as ações no artigo 301, $\S 2^{\circ}$. Dentre esses elementos, as partes dariam a dimensão subjetiva da ação, enquanto a causa de pedir e o pedido comporiam sua dimensão objetiva.

A dúvida que se levantou nos últimos anos, em tema dos contornos objetivos do processo, diz respeito à relevância da causa de pedir em sua determinação. Ao longo do desenvolvimento da teoria do objeto do processo litigioso (Streitgegenstand), obra da doutrina alemã, o conceito progrediu rumo a uma crescente abstração do estado de coisas em que se funda a pretensão (Anspruch), necessário à identificação do objeto litigioso segundo as teorias de ROSENBERG e LENT, até que se chegasse ao entendimento de que apenas o pedido já basta à identificação dos processos. Essa é precisamente a doutrina de KARL HEINZ SCHWAB, para quem o estado de coisas serve para fundamentar, mas não para individuar o objeto do processo. Em uma perspectiva diversa, que parte do direito material, ARTHUR NIKISCH chega a conclusões afins ${ }^{318}$. Muito embora essa corrente pareça ter sido abandonada pela doutrina posterior ${ }^{319}$, ela encontrou ressonância em autores brasileiros como CÂNDIDo DinAmarco e Ovídio BAPTISTA DA SILVA.

\footnotetext{
${ }^{317}$ É o alerta que faz SIDNEY SANCHES (Objeto do processo e objeto litigioso do processo. Revista de Processo, São Paulo, n. 13, jan./mar. 1979).

${ }^{318}$ Duas revisões da evolução da doutrina alemã sobre o conceito do objeto litigioso do processo se encontram nos ensaios de ALFREDO BUZAID (Da lide: estudo sobre o objeto litigioso (1980). In: Estudos e pareceres de direito processual civil, São Paulo: Ed. Revista dos Tribunais, 2002. p. 72-132) e de CÂNDIDO RANGEL DINAMARCO (O conceito de mérito em processo civil, cit., p. 299-348). Também a obra de KARL HEINZ SCHWAB (El objeto litigioso en el proceso civil. Buenos Aires: Ejea, 1968) contém, em sua primeira parte, amplo comentário da bibliografia precedente.

${ }^{319} \mathrm{Em}$ um movimento pendular da doutrina, a HABSCHEID se atribui o retorno da defesa da compreensão dos fundamentos no objeto do processo (cf. BUZAID, Alfredo. Da lide: estudo sobre o objeto litigioso (1980), cit., p. 108). Nessa linha, PETTER GOTTWALD, que atualiza o atualmente tratado de ROSENBERG, abandonou a concepção de SCHWAB para incluir no conceito de objeto do processo o "fato da vida" a respeito do qual se pede a decisão ("Streitgegenstand ist somit das Begehren der durch Klageantrag und Lebensachverhalt bestimmten Entscheidung". GOTTWALD, Petter; SCHWAB, Karl; ROSENBERG, Leo. Zivilprozessrecht. 17. ed. Munique: C.H. Beck Editor, 2010. p. 508).
} 
Essa discussão tem relevância para o tema da res judicata porque, a depender da concepção mais ou menos ampla que se tenha a respeito do que constitua o objeto do processo, irá variar a extensão da coisa julgada. A se adotar a teoria de SCHWAB, para quem o objeto litigioso do processo civil é composto apenas pelo pedido, a coisa julgada assumiria contornos mais amplos para abranger também causas não deduzidas expressamente $^{320}$. Entre os autores brasileiros, OvíDIO BAPTISTA DA SILVA demonstrou simpatia pela concepção do objeto litigioso desse autor alemão, e veio a defender que os limites objetivos da coisa julgada abrangem não apenas os fatos constitutivos descritos pelo autor em sua demanda, mas também todos os outros que sejam com ele compatíveis, com abertura inclusive ao julgamento implícito ${ }^{321}$.

É verdade que essa implicação leva o próprio SCHWAB a considerar sua concepção inadmissível para a finalidade de delimitação coisa julgada, afirmando que para esse efeito o objeto do processo deve incluir o estado de coisas em que se substancia a pretensão ${ }^{322}$. E CÂNDIDO RANGEl DinAmARCO, que sustenta que o objeto do processo consiste tão somente no pedido do autor, muito embora critique a exceção que SCHWAB abre em sua definição ${ }^{323}$, ao tratar dos limites objetivos da coisa julgada, afirma também cingirem-se

\footnotetext{
${ }^{320}$ SCHWAB, Karl Heinz. El objeto litigioso en el proceso civil, cit., p. 203 e ss.

${ }^{321}$ O pensamento de OVÍDIO BAPTISTA DA SILVA pode ser sintetizado nas seguintes linhas: “(...) as questões que hão de ficar decididas, na forma da concepção do art. 468, serão as pertinentes à lide proposta, ficando estabelecido que cada demanda terá uma configuração peculiar, com a estrutura que o autor lhe emprestou, de modo que a sentença há de abrangê-la integralmente, sejam ou não deduzidas as alegações e defesas pertinentes. Se o fundamento exposto na inicial foram 'os danos culposamente causados à colheita', ter-se-á de identificar nessa demanda, como seu verdadeiro fundamento (causa petendi), além do fato descrito ('sucessos históricos'), todos os outros que com ele sejam compatíveis, de modo que a reapreciação dessa mesma cadeia de fatos numa futura demanda resultasse numa decisão discrepante (Schwab). Ter-se-ão, pois, como decididas (implicitamente) - porque são, na verdade, questão da lide submetida ao autor pelo juiz todas as possíveis causas que possam dar lugar à rescisão do contrato sob alegação de inadimplemento culposo do demandado." (Os limites objetivos da coisa julgada no atual direito brasileiro atual. In.

Sentença e coisa julgada: ensaios e pareceres. 4. ed. Rio de Janeiro: Forense, 2003. p. 136-137). Observe-se que, a partir da teoria de SCHWAB, o autor chega à conclusão de que a lide, em cujos contornos o artigo 468 do CPC circunscreve a coisa julgada, seria mais ampla do que aquela introduzida no processo por demanda do autor, abandonando o conceito formal proposto por LIEBMAN e acolhido por BUZAID na Exposição de Motivos do Código de 1973. Embora, ao responder à objeção de que essa construção legitima uma margem excessiva de insegurança e imprecisão, admita o autor uma dose de subjetivismo na caracterização da demanda, afirma que "não se pode dizer que a solução alvitrada seja novidade, pois outra coisa não recomendavam os textos romanos" (Idem, p. 137). Em nossa opinião, essa teoria introduz uma margem de insegurança inaceitável em torno dos limites da coisa julgada e destoa do direito positivo, que vincula explicitamente a lide à causa petendi pelo artigo $301, \S 2^{\circ}$ do Código de Processo Civil.

${ }^{322}$ SCHWAB, Karl Heinz. El objeto litigioso en el proceso civil, cit., p. 251.

${ }^{323}$ De início, DINAMARCO critica a teoria de SCHWAB pela falta de unitariedade do conceito por ele proposto: "em síntese: na opinião de Schwab objeto do processo seria (a) em relação ao cúmulo de demandas, à alteração da demanda e á litispendência, somente o pedido, mas (b) em relação à coisa julgada, o pedido mais a causa de pedir. É manifesta a arbitrária incoerência dessa distinção." (O conceito de mérito em processo civil, cit., p. 344) A seguir, afirma que "na própria teoria e disciplina legal da auctoritas rei judicatae há resposta capaz de eliminar a causa da indecisão daquele monografista e por à calva seu
} 
eles à causa de pedir ${ }^{324}$.

E assim tem necessariamente de ser, porque a exclusão de qualquer consideração em torno dos fundamentos do pedido comum, na comparação entre as duas pretensões, acabaria por privar de tutela jurídica conflitos disciplinados pelo direito de maneira essencialmente autônoma, pela circunstância acidental de convergirem elas para um pedido único. Os problemas a serem administrados pela delimitação objetiva da coisa julgada não estão apenas em evitar o conflito prático de julgados, mas também em de evitar o efeito de exclusão sobre pretensões não deduzidas e, por via de conseqüência, o julgamento implícito.

Sob essa perspectiva, a limitação do conceito de objeto do processo ao objeto do pedido acaba por esvaziar o valor científico do conceito, na medida em que ele fica despido de funções práticas e tem de ser reiteradamente deformado, pela inclusão da causa de pedir, para resolver os problemas em que se torna mais relevante a identificação das demandas, tais como a coisa julgada e, eventualmente, a litispendência. Dessa forma, o objeto do processo - a que corresponderão os limites da res judicata na dimensão objetiva - é dado pelo pedido, tal como qualificado pela causa de pedir ${ }^{325}$. Tem-se aí um primeiro delineamento do âmbito em que o julgado será imutável e indiscutível, que, no entanto, deve ser aprofundado no que diz respeito à caracterização da causa petendi.

equívoco final. Segundo entendimento generalizado, essa garantia constitucional tem o escopo único de afastar conflitos práticos entre julgados, não conflitos meramente teóricos. (...) Nenhum impasse prático cria eventual divergência entre duas sentenças quanto aos fatos em que se apóiam ou quanto à interpretação da mesma norma jurídica, desde que se refiram a objetos ou pedidos diferentes. Uma delas pode até ser injusta ou mesmo errada (e não há porque dizer que seja sempre a segunda), mas ambas são exeqüíveis e podem conviver, sem se excluírem, porque não projetam preceitos conflitantes na vida comum dos litigantes. Ocorrem, nesses casos, meros conflitos teóricos de julgados" (Idem, p. 345-346). A preocupação de SCHWAB, no entanto, não parece ter sido a de estender a coisa julgada a questões compreendidas na fundamentação da sentença, mas o de evitar o efeito de exclusão sobre pretensões autônomas; nesse sentido, o princípio da finalidade prática da coisa julgada não parece dar resposta convincente às inquietações por ele manifestadas.

${ }^{324}$ "Negar o direito a um objeto não significa necessariamente que o mesmo sujeito não tenha direito a outro objeto; nem a negativa da existência de determinado fundamento para que ele tenha direito ao bem da vida constitui negativa de que por outro fundamento ele o tenha" (DINAMARCO, Cândido Rangel. Instituições de direito processual civil, cit., v. 3, p. 322); No mesmo sentido e do mesmo autor, O conceito de mérito em processo civil, cit., p. 346-347.

${ }^{325}$ Outra não é a conclusão de BOTELHO DE MESQUITA: “(...) causa petendi e petitum, intimamente ligados, qual verso e reverso da mesma medalha, ou alicerces e paredes do mesmo edifício, são por excelência os elementos identificadores do objeto do processo, pois o petitum é condição de existência da causa petendi e esta, por sua vez, não se limita a qualificá-lo ou restringi-lo, mas o individua plenamente." (A causa petendi nas ações reivindicatórias. In: Teses, estudos e pareceres de processo civil: direito de ação - partes e terceiros - processo e política. São Paulo: Ed. Revista dos Tribunais, 2005. v. 1, p. 140). 


\subsubsection{Os problemas relacionados à determinação da causa petendi}

Dentre os elementos da demanda, em sua função de distinguir ou de caracterizar a identidade de dois processos em comparação, certamente o de mais difícil definição é o da causa de pedir, isto é, dos fundamentos do pedido ${ }^{326}$. Essa dificuldade provém de uma intensa polêmica processual, que remonta à distinção que os glosadores medievais fizeram entra a causa petendi remota e causa petendi proxima ${ }^{327}$, em torno da questão de se devem ser considerados como fundamentos da pretensão os fatos ou a relação jurídica de que deriva o pedido.

A partir da entrada em vigor da Zivilprozeßordnung alemã de 1877, a doutrina se dividiu em duas correntes em torno da obrigação que o $\$ 253$ estabelecia no sentido de que a inicial expusesse os fundamentos da pretensão que sustenta o pedido. A primeira dessas teorias, a da substanciação da causa de pedir, defendeu que tais fundamentos consistiam nos fatos jurídicos, isto é, no estado de coisas disciplinado pela lei, a respeito da qual se buscava a tutela jurisdicional. A segunda delas, a teoria da individuação, partindo da idéia de que a finalidade do processo é a tutela do direito objetivo, sustentou que os fundamentos da pretensão nada mais eram do que a relação jurídica em si mesma, sem que os fatos tivessem maior importância para a sua configuração. Os papéis da causa petendi proxima e da causa petendi remota na identificação do objeto do processo progrediram, assim, de uma relação complementaridade para uma relação de oposição e exclusão.

Tradicionalmente, a ampla maioria da doutrina brasileira entende que nosso Código de Processo Civil adotou a teoria da substanciação da causa de pedir, mesmo diante de ter ele estabelecido serem requisitos da inicial a "indicação do fato e dos fundamentos jurídico do pedido" (art. 282, inciso III). Isto se explica pelas circunstâncias de que os fatos devem ser expostos de maneira concentrada na inicial e na contestação (princípio da eventualidade: artigos 282, inciso III, e 300) e de que o juiz tem liberdade em dar aos fatos

\footnotetext{
326“Na verdade, não surgem verdadeiramente problemas sobre o que se deva entender por personae e por petitum. A causa petendi, contudo, pela dificuldade que oferece à determinação do seu conteúdo, tornou-se um dos pontos mais delicados do direito processual, e isto por se achar no âmago do tema comumente designado por identificação das ações, do qual dependem decisivamente vários institutos processuais" (BOTELHO DE MESQUITA, José Ignácio. A causa petendi nas ações reivindicatórias, cit., p. 141).

327، “Apesar de já ter sido intuída por Neracio, no fragmento (D. 44.2.27) por nós examinado em momento adequado, Petrus de Ferrariis, ao que parece, é que teria constatado pela primeira vez a distinção entre causa petendi remota e causa petendi proxima, depois repetida ininterruptamente pelas subseqüentes gerações de juristas" (CRUZ E TUCCI, José Rogério. A causa petendi no processo civil, cit., p. 61).
} 
qualificação diversa daquela que lhes foi atribuída pelas partes ("iuria novit curia": art. 126).

As posições extremas em torno da tese da individuação e da substanciação, ao que indica, foram influenciadas pelas idéias que os seus defensores tinham em relação a uma questão mais afeta à técnica processual, perdendo de vista a finalidade primordial do instituto, que é a identificação do conteúdo dos processos. Partindo da pressuposição de que os contornos da lide devem ser integralmente dados a conhecer já no ato introdutivo do processo, a substanciação de amolda a um processo rígido, em que os fatos principais devem ser alegados na primeira oportunidade segundo a regra da eventualidade ${ }^{328}$; e a individuação, em contrapartida, é consentânea a um processo flexível em que os fatos podem ser gradualmente introduzidos em juízo de acordo com a evolução do debate entre as partes, de forma que o contraditório pode ser apenas preparado pela enunciação da pretensão que se quer fazer valer. Segundo os defensores de cada qual, se teria assim a oposição de um modelo mais célere a um modelo que propicia uma solução mais perfeita do conflito. Entretanto, muito embora o sistema de preclusões e estabilização do processo seja, sem dúvidas, relacionado ao tema da causa de pedir (o ideal é que os fundamentos do pedido não variem, ou variem ao mínimo no curso do procedimento), não é a partir dele que se podem deduzir os critérios de identificação de uma pretensão frente a outra ${ }^{329}$.

E dessa forma, a partir do momento em que a doutrina passou a analisar o tema da causa petendi a partir do direito material tutelado, segundo o movimento de reaproximação entre direito e processo de que tratamos no item 3.1.2, o que se verificou foi uma tendência rumo à relativização das duas teorias. De início, autores italianos - país onde era amplamente aceita a tese da individuação da causa de pedir - constataram que

\footnotetext{
328“"A eventualidade, impondo um sistema rígido de preclusões, constitui, como já procuramos patentear, pressuposto da teoria da substanciação, ao exigir a exposição simultânea, na petição inicial, dos fatos que fazem emergir a pretensão do demandante (causa petendi remota) e do enquadramento da situação concreta, narrada in statu assertionis, à previsão abstrata, contida no ordenamento de direito positivo, e do qual decorre a juridicidade daquela (causa petendi próxima). Compreende-se, pois, o determinismo imanente pelo qual, historicamente, os ordenamentos caracterizados por tal sistema preclusivo sempre adotaram um modelo processual polarizado mais sobre o fato do que sobre o direito, levando, por isso, a idéia de substanciação às últimas consequiências" (CRUZ E TUCCI, José Rogério. A causa petendi no processo civil, cit., p. 161).

${ }^{329}$ De fato, há razões para se duvidar da validade do pressuposto que estabelece a relação entre o conteúdo da causa de pedir e o regime ideal de preclusões. A flexibilidade na introdução de fatos durante uma fase do processo não é incompatível com a teoria da substanciação da causa de pedir, desde que se admita que nesse período foi permitida a livre variação da causa petendi. A individuação da causa de pedir, de igual maneira, poderia ser compatibilizada com um sistema de preclusão na alegação de fatos, desde que isso seja enxergado exclusivamente sob o ângulo da preclusão preocupada com a ordenação do procedimento e nada mais. Dessa forma, embora haja relação entre os dois modelos de procedimento e as teorias da individuação e substanciação, não há uma relação de determinação necessária entre eles.
} 
determinados direitos de caráter absoluto, como a propriedade, somente poderiam subsistir uma vez com o mesmo conteúdo entre as mesmas pessoas: são direitos autodeterminados, em que a menção à relação jurídica basta para identificar a pretensão (talvez se possa dizer, com maior exatidão, que nesses casos é "tênue" a substanciação exigida ${ }^{330}$ ). Outros direitos podem existir diversas vezes, com o mesmo conteúdo, entre as mesmas pessoas, como é o caso das obrigações: são direitos heterodeterminados, que não podem ser distinguidos um do outro se não se fizer também menção ao fato que lhes deu origem. Essa atenuação do critério da individuação, posteriormente, viria a se desenvolver rumo a uma concepção da causa de pedir orientada pela fattispecie abstrata da norma jurídica ${ }^{331}$ que constitui o fundamento da pretensão, deduzida no estado de asserção $^{332}$, determinando-se a causa de pedir pelos fatos constitutivos abstratamente previstos na norma de direito material aplicável.

De igual maneira, os desenvolvimentos mais recentes da doutrina vieram a atenuar grandes rigores na aplicação do critério da substanciação, na medida em que em determinadas ocasiões - especialmente quando o suporte fático da regra invocada remeter a conceitos jurídicos e não a fatos da vida - a simples narração dos fatos não será suficiente para a identificação da causa, e preponderará na identificação da demanda o fundamento jurídico da pretensão. Nesse sentido, BoTELHO DE MESQUITA aponta que o Código de Processo Civil adotou solução de grande equilíbrio entre as teorias da individuação e da substanciação ${ }^{333}$, de modo que tanto fato como relação jurídica mostramse importantes para a identificação da pretensão, de maneira mais ou menos acentuada a depender da circunstância. Essa interpretação nos parece adequada como a única capaz de resolver determinadas situações-limite (por exemplo, a identificação de demandas nas ações rescisórias por violação à lei), embora se perceba uma inclinação mais acentuada de nossa lei processual pela tese da substanciação da causa petendi. Mas mesmo isto é uma conseqüência da premissa de que a causa de pedir é determinada pela regra de direito

\footnotetext{
${ }^{330}$ LEONEL, Ricardo de Barros. Causa de pedir e pedido: o direito superveniente. São Paulo: Método, 2006. p. 96.

${ }^{331}$ PROTO PISANI, Andrea. Lezioni di diritto processuale civile. 5. ed. Napoli: Jovene, 2006. p. 57.

${ }^{332}$ ELIO FAZZALARI, precisamente, sublinha que a causa de pedir marca o ingresso do direito substancial no processo, funcionando como o elo de coordenação entre direito e processo. Assim, "preme, invece, di sottolineare subito che la allegazione della causa petendi alle soglie del processo, e comunque necessariamente prima che esso si addentri nella trattazione di merito, segna l'ingresso del diritto soggetivo (sostanziale) nel giudizio di cognizione" (FAZZALARI, Elio. Note in tema di diritto e processo, cit., p. 122).

${ }^{333}$ BOTELHO DE MESQUITA, José Ignácio. A causa petendi nas ações reivindicatórias, cit., p.154-155. Compartilham do mesmo entendimento grande parte dos autores que se ocuparam mais detidamente do tema da causa de pedir em nosso país, a exemplo de MILTON PAULO DE CARVALHO (Do pedido no processo civil. Porto Alegre: Sérgio Antonio Fabris Editor, 1992. p. 92-93), JOSÈ ROGÉRIO CRUZ E TUCCI (CRUZ E TUCCI, José Rogério. A causa petendi no processo civil, cit., p. 125-127) e RICARDO DE BARROS LEONEL (Causa de pedir e pedido: o direito superveniente, cit., p. 93-96).
} 
material que disciplina a relação litigiosa, na medida em que a lei, na grande maioria das vezes, se ocupa de fatos da vida ao escolher seus pressupostos normativos, raramente remetendo a outros conceitos jurídicos para essa finalidade.

Assim, dessa convergência resulta que, sob o aspecto dos fundamentos fáticos, a causa petendi é determinada apenas pelos fatos jurídicos, isto é, ela se centra naqueles fatos qualificados por lei, mediante sua previsão em uma fattispecie abstrata encontrada no direito objetivo. Já os fatos simples, que entram no processo como ponto de apoio da argumentação e instrumento de convencimento do juiz, não têm relevância para a delimitação da lide. De outro lado, no que toca ao fundamento jurídico, a causa de pedir não é determinada pelo texto de lei específico, mas pelo efeito jurídico pretendido pelo autor. Basta ao autor assim narrar os fatos essenciais e a pretensão, que isso bastará para que se depreenda o fundamento jurídico do pedido ${ }^{334}$.

A causa de pedir exercerá, assim, grande influência sobre o regime da coisa julgada. Demonstração disso foi dada por WALTER PIVA RODRIGUES no campo do direito processual tributário. Como se sabe, há tradicional orientação no sentido de que a coisa julgada se limita à desconstituição de um lançamento específico ${ }^{335}$, permanecendo a impossibilidade de tributação no campo dos fundamentos que não adquirem relevância para fora do processo. Entretanto, toda tributação se funda em uma relação jurídica de sujeição tributária, cuja inexistência pode ser objeto de uma pretensão declaratória, inclusive pela via da declaração incidental. E assim se os elementos que impedem o estabelecimento dessa relação permanecem os mesmos, sem que haja variação na causa de pedir $^{336}$, a coisa julgada formada nessa ação declaratória se estenderá para quaisquer lançamentos futuros ${ }^{337}$.

\footnotetext{
${ }^{334}$ CARVALHO, Milton Paulo de. Do pedido no processo civil, cit., p. 93-95.

${ }^{335}$ Orientação que é sintetizada por LIEBMAN no sentido de que "no executivo proposto para cobrar o imposto correspondente a determinado exercício financeiro, a questão da tributabilidade de certa verba patrimonial representa, se for objeto da controvérsia, justamente uma questão prejudicial" (LIEBMAN, Enrico Tullio. Limites da coisa julgada em matéria de imposto. In:___. Estudos sobre o processo civil brasileiro. 2. ed. São Paulo: Bushatsky, 1976. p. 173), que não é alcançada pela coisa julgada.

336،Essa assertiva revela a repercussão na área tributária dos prefalados limites mediante incidência do conhecido binômio - o pedido referido a uma certa causa de pedir - que pela petição inicial introduz a 'lide tributária' no devido processo legal” (PIVA RODRIGUES, Walter. A crise no conceito da coisa julgada, em especial em matéria tributária. Revista do Advogado, São Paulo, ano 26, n. 88, p. 176, 2006).

${ }^{337}$ PIVA RODRIGUES, Walter. Coisa julgada tributária, cit., p. 104 e ss. Cabe destacar que a tese, polêmica à época, veio a encontrar acolhida na jurisprudência do Superior Tribunal de Justiça, a partir do julgamento do Recurso Especial 731.250/PE, que posteriormente foi confirmado pela Corte Especial em embargos de Divergência. Ali se decidiu que "1. A Súmula 239/STF, segundo a qual 'decisão que declara indevida a cobrança do imposto em determinado exercício, não faz coisa julgada em relação aos posteriores', aplica-se tão-somente no plano do direito tributário formal porque são independentes os lançamentos em cada
} 
Mas os elementos da causa de pedir podem variar, hipótese em que não se aplicará essa conclusão. De fato, como a causa de pedir é aberta à influência de fatos subseqüentes, que podem ter eficácia modificativa sobre o efeito jurídico existente quando da prolação da sentença de mérito, a vinculação da coisa julgada aos limites da lide se reflete nos chamados limites cronológicos da coisa julgada ${ }^{338}$. A expressão remete à transitoriedade dos efeitos da sentença e à possibilidade de que eles sejam, exatamente como quaisquer outros atos jurídicos, modificados ou extintos por fatos supervenientes. Dada a limitação da coisa julgada ao estado de fato existente quando do julgamento, a coisa julgada não inibirá uma segunda demanda sobre a relação jurídica modificada, porque se tratará de lide diversa $^{339}$. De fato, para algumas situações, relações continuativas em que caiba ao juiz determinar o conteúdo da obrigação, como é o caso das ações de alimentos ou a renovação de locação comercial, o Código prevê expressamente a ação revisional (art. 471, inc. I, do Código de Processo Civil $)^{340}$. Em outros casos, que não digam respeito a pretensões determinativas, as alterações introduzidas por disciplina jurídica posterior se aplicarão de imediato, sem necessidade de ação de revisão (por exemplo, a alteração do padrão monetário em que se expressa a condenação líquida).

exercício financeiro. Não se aplica, entretanto, se a decisão tratou da relação de direito material, declarando a inexistência de relação jurídico-tributária. 2. A coisa julgada afastando a cobrança do tributo produz efeitos até que sobrevenha legislação a estabelecer nova relação jurídico-tributária. (Segunda Turma, rel. Min. ELIANA CALMON, j. 17.04.2007, p. DJ 30.04.2007). Com argumento fundado em política legislativa, isto é, a possibilidade de tratamento privilegiado para contribuinte em caso de alteração de entendimento jurisprudencial, JOSÉ MARIA ROSA TESHEINER defende a limitação peremptória da coisa julgada a lançamentos tributários específicos (Eficácia da sentença e coisa julgada no processo civil, cit., p. 169). Entretanto, esse entendimento carece de fundamento legal no plano do direito processual civil e somente seria admissível mediante a restrição do direito de ação, que eventualmente proibisse a propositura da ação declaratória de inexistência da relação de sujeição tributária.

${ }^{338}$ Como afirma JOSÉ MARIA ROSA TESHEINER, "os chamados limites temporais do caso julgado reconduzem-se aos limites objetivos decorrentes da causa de pedir" (Eficácia da sentença e coisa julgada no processo civil, cit., p. 163).

${ }^{339}$ Nos termos da explicação de SÉRGIO GILBERTO PORTO, “(...) a decisão jurisdicional regula a relação jurídica somente nos limites da situação substancial posta sub judice e não para todo o sempre, ou, dito de outro modo, nos limites temporais da causa petendi. Dessa forma, pois, possível afirmar que a autoridade da coisa julgada tem sua capacidade eficacial também limitada pela equação tempo da decisão/fatos apreciados, ou, ainda, mais precisamente, quer as conseqüências jurídicas estejam sujeitas a adequações em face da natureza da relação jurídica de direito material ou não, a verdade é que a decisão tem seus limites também determinados pelo tempo dos fatos que foram considerados ou que deveriam ter sido considerados pela decisão, portanto pré-existentes a esta." (Coisa julgada civil, cit., p. 81-82).

${ }^{340}$ Buscando responder se esse dispositivo veicularia regra de mitigação da coisa julgada, EDUARDO TALAMINI afirma que "a peculiaridade não reside na coisa julgada, mas na natureza da relação jurídica 'continuativa', que, em vista de seu caráter dinâmico e sua duração continuada no tempo, dá ensejo à constituição de novas causas de pedir no seu próprio curso" (A coisa julgada no tempo: os "limites temporais" da coisa julgada. Revista do Advogado, São Paulo, n. 88, p. 58, nov. 2006). No mesmo sentido, o clássico ensaio de ADROALDO FURTADO FABRÍCIO sobre o assunto se encerra com a conclusão de que "a sentença de alimentos em nada se singulariza na comparação com quaisquer outras e na perspectiva da coisa julgada material, sendo perfeitamente dispensável qualquer disposição legal específica sobre o tema" (A coisa julgada nas ações de alimentos, cit., p. 27). 


\subsubsection{Os elementos lógicos da sentença não são cobertos pela coisa julgada}

Prosseguindo na linha de análise que adotamos, a teoria da coisa julgada no direito brasileiro é condicionada por determinadas condições institucionais que conformam a jurisdição no Estado de Direito. Segundo o modo como a Constituição a moldou, trata-se de função do Estado que visa à finalidade prática de compor os conflitos por meio da aplicação do direito. Essa concepção coloca em primeiro plano a decisão do caso, como ato de vontade do Estado dirigido à situação em concreto, e relega a um papel secundário a sua formação lógica, pois em última instância a legitimidade do ato não reside propriamente na sentença, mas na lei que por meio dela foi aplicada. Do ponto de vista da técnica processual, tal configuração levou a doutrina a dividir a estrutura da sentença em dois grupos de elementos, a partir da finalidade por eles desempenhada: o elemento lógico e o elemento decisório.

Como já expusemos anteriormente, a concepção publicística do processo colocou em segundo plano a formação lógica da decisão, para privilegiar na teoria da coisa julgada o resultado prático do processo. Isso leva CHIOVENDA à afirmação, sem dúvidas exagerada (pois é um direito das partes exigirem a fundamentação da decisão), de que o juiz "enquanto razoa, não representa o Estado; representa-o quando lhe afirma a vontade"341. Com base nesse princípio, muito cedo a doutrina brasileira passou a afirmar a limitação da coisa julgada ao dispositivo da decisão ${ }^{342}$, em uma linha de princípio que se manteve firme ao longo dos tempos, e que, como veremos na seqüência, apenas recentemente veio a ser posta em questão.

Mas no panorama da doutrina européia o assunto sempre foi dos mais controvertidos. Uma influente defesa da inclusão dos motivos no âmbito de incidência da

\footnotetext{
${ }^{341}$ CHIOVENDA, Giuseppe. Instituições de direito processual civil, cit., v. 1, p. 372.

${ }^{342}$ Nesse sentido, PAULA BATISTA afirmava ainda no século XIX que "a coisa julgada é restrita à parte dispositiva do julgamento e aos pontos aí decididos e fielmente compreendidos em relação aos seus motivos objetivos" (PAULA BAPTISTA, Francisco de. Compendio de theoria e prática do processo civil comparado com o comercial e de hermenêutica jurídica, cit.); enquanto, no início do século passado, JORGE AMERICANO ensinava que "aos motivos, pois, só deve ser atribuída a autoridade de coisa julgada quando fazem corpo com o dispositivo da sentença, são parte integrantes deste, fundamentam n'o de tal forma que nelles esteja a própria razão de ser do dispositivo, de maneira que, abstrahido o dispositivo, a controvérsia não teria ficado dirimida só pelo dispositivo da sentença, digamos, desapareceria o próprio dispositivo, e, portanto, a sentença. Numa palavra, deve se procurar a cousa julgada em qualquer parte da sentença onde esteja resolvida a relação de direito controvertida na demanda e, conseguintemente, no motivo, quando neste estiver expressa tal relação como causa imediata do dispositivo da sentença" (Processo Civil e comercial no direito brasileiro: phases probatória, decisória e executória. São Paulo: Livraria Acadêmica Saraiva e cia, 1925. p. 237).
} 
coisa julgada foi feita no século XIX por FrIEDERICH KARL vON SAVIGNY, expoente da Escola Histórica que buscava inspiração nos princípios do processo comum romanogermânico do período medieval. Se por um lado o iudicium medieval tinha a virtude de se apresentar maleável ao costume e às mudanças da sociedade, valores que SAVIGNY entendia ameaçados pelo movimento da codificação do direito ${ }^{343}$, por outro lado ele apresentava os inconvenientes associados à excessiva valorização do elemento lógico que foram tão bem expostos por CHIOVENDA no início do século passado. O autor alemão distinguia entre os motivos subjetivos da decisão e os motivos objetivos, ligando os primeiros à formação da convicção do juiz e o segundo às relações jurídicas que são pressupostos do dispositivo. A estes, mas não àqueles, se estenderia a autoridade da coisa julgada. ${ }^{344}$ Sua construção é plenamente coerente com a sua teoria da coisa julgada como ficção de verdade (Fiktion der Warheit), a que já nos referimos no item 3.2.2 supra, que não se preocupava apenas com a função prática da coisa julgada, mas também com sua integridade no plano do argumento, já que este era responsável pela função de legitimação dos critérios de decisão judicial que na modernidade viria a ser assumida pela lei. Uma conclusão verdadeira obrigatoriamente deve se apoiar em premissas verdadeiras, de modo que o dispositivo protegido pela res judicata somente poderia se apoiar em "motivos objetivos" igualmente inatacáveis.

Também nesse aspecto, a doutrina de SAVIGNY foi objeto da crítica de CHIOVENDA, para quem a teoria da coisa julgada somente deveria se preocupar com os conflitos práticos entre julgados, de modo que não haveria qualquer inconveniente em que as questões resolvidas pelo juiz ao longo da formação lógica da decisão da causa não transcendessem os limites do processo. Na realidade, como a análise de todo o material lógica da sentença tem natureza instrumental, ou seja, é feito sempre à vista da finalidade pretendida pelo autor, o ideal mesmo é que a resolução das questões de fato e direito fiquem confinadas à causa onde se deu a decisão ${ }^{345}$.

\footnotetext{
${ }^{343}$ SAVIGNY, Friedrich Karl. Vocazione del nostro secolo per la legislazione e la giurisprudenza. Bologna: Forni, 1968.

344“De todo esto resulta que la autoridad de la cosa juzgada se extiende a los motivos de la sentencia; en otros términos la autoridad de cosa juzgada que pertenece a la sentencia es inseparable de las relaciones de derecho afirmadas o negadas por el juez; pues la parte puramente práctica de la sentencia; el acto imposto al demandado, o la absolución de la demanda, no es más que la consecuencia de estas relaciones de derecho". SAVIGNY, Friedrich Karl. Sistema del derecho romano actual. Madrid: F. Góngora e Compañia, 1879. t. 5, p. 227-228.

${ }^{345}$ Comenta DINAMARCO que "é muito cara à doutrina dos processualistas a assertiva de que a jurisdição se exerce sempre em face de casos concretos e que ela não tem o escopo institucional de dar solução a questões. No exercício da atividade jurisdicional o juiz dá, sim, solução a questões, mas ele o faz apenas em
} 
Afinado com essas idéias, o artigo 469 do Código de Processo Civil de 1973 dispõe que não fazem coisa julgada: os motivos, ainda que importantes para determinar o alcance da parte dispositiva da sentença; a verdade dos fatos, estabelecida como fundamento da sentença; e a apreciação da questão prejudicial, decidida incidentemente no processo. Aliás, o código de Processo Civil de 1973 tratou com uma clareza ser par a disciplina dos limites objetivos da coisa julgada, pelo sistema dos artigos 468, 469 e 470. O primeiro deles circunscreve a coisa julgada à lide (conforme vimos no item 3.3.1, supra); o segundo limita-a, por exclusão, ao dispositivo da sentença; e o último condiciona a eficácia panprocessual da resolução de questão incidental ao pedido de declaração incidente. Desse conjunto, resulta claro que os elementos lógicos do raciocínio do juiz não estão compreendidos em nenhuma hipótese na coisa julgada, sob a lei brasileira.

Somente se torna imutável e indiscutível o dispositivo, isto é, a conclusão última do raciocínio do juiz sobre o mérito da causa. O dispositivo, portanto, não se determina por sua localização topológica no texto da sentença, mas pelo critério substancial do conteúdo decisório que o ato judicial exprime. A expressão "deve ser entendida em sentido substancial e não apenas formalístico, de modo que compreenda não apenas a frase final da sentença, mas também tudo quanto o juiz haja considerado e resolvido acerca do pedido feito pelas partes" 346 .

Mas de outro lado é certo que a motivação, embora não integre a coisa julgada, adquire uma importante função prática na identificação dos seus limites. Isto porque, de acordo com o princípio de que os elementos para identificação da coisa julgada devem ser buscados na sentença e não em elementos externos, é justamente através dos motivos que se pode identificar a causa de pedir sob a qual foi debatido o pedido. É esse o contexto em que LIEBMAN afirma que os motivos "constituem a miúde indispensável elemento para determinar com exatidão o significado e o alcance do dispositivo"347. Já EDUARDO COUTURE observa que no caso das sentenças de improcedência, que negam o efeito

um segmento do item lógico de sua atividade, ao colocar os pilares sobre os quais se assentará depois o serviço acabado, que é a solução da causa. A jurisdição não tem vocação às generalizações" (O conceito de mérito em processo civil, cit., p. 310).

${ }^{346}$ LIEBMAN, Enrico Tullio. Limites objetivos da coisa julgada, cit., p. 164. Adotando essa mesma abordagem substancial do dispositivo, JOSÉ IGNÀCIO BOTELHO DE MESQUITA sintetiza a interpretação do art. 469 do CPC com a afirmação de que "transitada a sentença em julgado, tornar-se-ão imutáveis e indiscutíveis os elementos restantes, a saber: o elemento declaratório, a que já nos referimos, a manifestação de vontade (sentenças de procedência) e o juízo de rejeição do pedido (sentenças de improcedência)." (A coisa julgada. In:___. A coisa julgada, cit., p. 7).

${ }^{347}$ A coisa julgada. In: __ A coisa julgada, cit. 
pretendido pelo autor e nada alteram na realidade externa ao processo, é apenas a partir da consulta dos fundamentos que se pode determinar qual foi a lide julgada ${ }^{348}$.

\subsubsection{Em particular: as questões prejudiciais}

O ponto em que o debate relativo à extensão da coisa julgada aos fundamentos da sentença realmente ganha relevância é aquele que diz respeito às questões prejudiciais. As dificuldades se iniciam já na conceituação do que seja a questão prejudicial: durante muito tempo a doutrina adotou um critério puramente cronológico para definir a prejudicialidade, assimilando ao conceito as diversas questões prévias resolvidas pelo juiz, das mais diversas naturezas, no curso da formação da decisão ${ }^{349}$. De fato, o raciocínio do juiz ao decidir consiste em uma cadeia de questões de diversa natureza (questões processuais, questões sobre os fatos demonstrados pela prova e sua qualificação jurídica, questões relacionadas ao mérito e, finalmente, o mérito em si), que ele resolve de forma ordenada, de maneira tal que cada uma delas subordina a resposta que há de ser dada a seguinte. Do ponto de vista cronológico, todas elas subordinam a questão seguinte na cadeia silogística desenvolvida na motivação: são questões prévias, ou preliminares.

Mas a prejudicialidade que tem relevância para o direito, na lição de FRANCESCO MENESTRINA, é apenas a prejudicialidade jurídica, ou seja, o vinculo de subordinação necessária que se encontra na própria estrutura do direito a cuja tutela se dirige o processo. A questão prejudicial, assim, ingressa como um dos elementos do suporte fático da lide subordinada, de modo que a decisão que se tome a respeito dela influirá de modo decisivo na procedência ou improcedência da pretensão dependente ${ }^{350}$. Dentre as matérias contidas na fundamentação da sentença, a decisão sobre fatos e fundamentos jurídicos é intrinsecamente instrumental e não teria nenhuma aptidão a adquirir projeção externa, pois a definição dos fatos representados pela prova produzida na fase instrutória, e bem assim a definição da norma aplicável, consistem tão somente em premissas lógicas que não teriam

\footnotetext{
${ }^{348}$ Diz ele: "deve admitirse que la necesidad de acudir a los motivos es absoluta en ciertas circunstancias. Así, por ejemplo, en las sentencias que absuelven pura y simplesmente de la demanda, nunca será posible determinar el alcance exacto de la cosa juzgada, y, en especial, el objeto y la causa petendi, sin acudir a la motivación de la sentencia". (COUTURE, Eduardo. Fundamentos del derecho procesal civil, cit., p. 349).

${ }^{349}$ MENESTRINA, Francesco. La pregiudiciale nel processo civile. Milano: Giuffrè, 1963. p. 99.

350،A denominação de prejudiciais é, pois, a que histórica e logicamente mais convém às questões de cuja solução dependa o teor da solução de outras." (BARBOSA MOREIRA, José Carlos. Questões prejudiciais e questões preliminares. In: Direito processual civil: ensaios e pareceres. Rio de Janeiro: Editor Borsói, 1971. p. 86).
} 
condições de se impor em um processo futuro, em razão de sua elevada abstração. A situação das questões prejudiciais é distinta, porém, porque ao resolvê-las, o juiz faz um juízo parcial de subsunção do caso concreto à hipótese normativa. Ou seja, na resolução da prejudicial não há apenas o estabelecimento de premissas lógicas, mas também a aplicação do direito ao caso concreto ${ }^{351}$.

Apesar disso, uma primeira circunstância que recomenda a sua exclusão do campo de incidência da coisa julgada é que, por não constituírem o objeto da pretensão, o juiz delas conhece de maneira normalmente superficial, resolvendo-as em caráter incider tantum, como uma das etapas de formação do raciocínio que está teleologicamente voltado para a finalidade de decidir a pretensão. Ou seja, embora também haja aplicação da lei ao caso concreto na resolução a questão prejudicial, isso é feito de maneira instrumental à decisão da lide que constitui o mérito do processo, razão pela qual ela também acaba por se inserir no material lógico - e não no dispositivo decisório - da sentença. Por isso se diz que o juiz resolve a questão prejudicial na construção lógica do dispositivo, mas não a decide.

Além disso, uma mesma questão prejudicial pode ter repercussões muito mais amplas do que aquelas relacionadas ao objeto do pedido. Um mesmo fato pode ter relevância para diversas fattispecie concretas, de modo que sua qualificação sob determinada figura jurídica pode gerar conseqüência imprevistas pelas partes quando da elaboração da demanda ou da defesa. Se elas viessem a se tornar indiscutíveis em processos futuros, essa circunstância não apenas exigiria das partes um esforço desproporcional aos limites da causa na identificação das prejudiciais potencialmente lesivas sugeridas pela demanda ${ }^{352}$, como poderia gerar efetivo prejuízo aos direitos de defesa e de acesso à justiça ${ }^{353}$.

\footnotetext{
${ }^{351}$ Nesses termos MENESTRINA afirma que a resolução das questões prejudiciais (prejudicialidade jurídica) se diferencia da resolução das questões prévias (prejudicialidade lógica) por ser da mesma natureza que a decisão final sobre o mérito da causa. "La pregiudicialità giuridica nasce dell'unirsi di un novo elemento alla pregiudicialità logica: e il nuovo elemento è l'eguale natura del giudizio pregiudiciale e del finale. Da ciò segue che tutto quello che è giuridicamente pregiudiciale è tale anche logicamente, ma non viceversa". (La pregiudiciale nel processo civile, cit., p. 92).

352 "Do ponto de vista prático, deve-se observar que o estender-se a coisa julgada a tôdas as questões decididas poderia encerrar alguma vantagem, porque evitaria algum processo futuro e decisões contraditórias. Seriam, porém, muito mais graves os inconvenientes de semelhante extensão. As partes, ao proporem uma ação ou se defenderem, não teriam nenhuma certeza sôbre os limites e o alcance da lide; e seriam forçadas a preparar um esforço de ataque e de defesa efetivamente desproporcionado à sua intenção" (CHIOVENDA, Giuseppe. Instituições de direito processual civil, cit., v. 1, p. 394).

${ }^{353}$ Nessa perspectiva, ANDREA PROTO PISANI afirma que há fundamento constitucional para a impossibilidade de extensão da coisa julgada a questões prejudiciais: "posto, infatti, che il fatto storico è fonte di una seria indefinita di fattispecie e come tale può essere rilevante ai fini di più e diversissimi effetti giuridici, se non viene precisato quale sia la fattispecie con riferimento alla quale si agisce, il convenuto non sapprebe qual è il bene della vita cu cui l'accertamento è destinato ad incidere" (Lezioni di diritto processuale civile. 5. ed., cit., p. 139).
} 
O caráter restritivo do Código vigente se deve à circunstância de que a abrangência dos fundamentos da decisão pela coisa julgada foi objeto de intensa polêmica e grande insegurança sob a lei anterior, cuja disciplina previa - no parágrafo único do artigo 287 que "considerar-se-ão decididas todas as questões que constituam premissa necessária da decisão". Parece ser correto afirmar que a lei, então, realmente pretendia incluir as questões prejudiciais no âmbito de indiscutibilidade proporcionado pela res judicata, na medida em que o projeto elaborado por PEDRO BATISTA MARTINS para o antigo código fora colher inspiração no texto do projeto apresentado em 1926 por LODOVICO MORTARA para a reforma da lei italiana. Este autor, em seu Commentario ${ }^{354}$, manifestava aberta simpatia pela tese de SAVIGNY acerca da formação de coisa julgada sobre os "motivos objetivos" da decisão. Ainda assim, havia um forte movimento doutrinário que sustentava a interpretação de que na realidade a regra do parágrafo único do art. 287 dizia respeito à eficácia preclusiva da coisa julgada, imperfeitamente formulada no texto da lei sob a ótica do “julgamento implícito”. Nesse primeiro grupo se encontravam ENRICO TULLIO LIEBMAN ${ }^{355}$, José IGNÁCIO BotelHo de MESQUitA ${ }^{356}$ e BARBosA MoreIRA ${ }^{357}$. E havia também os que, aceitando a extensão da coisa julgada aos motivos, apontavam a inconveniência da norma, diante dos termos amplos e vagos em que foi formulada ${ }^{358}$. De qualquer forma, tem-se que eram amplas as críticas ao artigo 287, e isso provavelmente foi o que levou o legislador de 1973 a ser tão cuidadoso com o assunto.

Sob o Código de 1973, que atendeu às manifestações da doutrina e regulamentou de maneira clara os limites objetivos da coisa julgada, se verificou movimento inverso àquele que existia sob o regime da lei anterior, e passaram a surgir teses a defender a extensão da coisa julgada aos motivos da decisão. De lege lata, assim, a monografia RONALDO CUNHA CAMPOS defendeu a extensão da coisa julgada à decisão das questões prejudiciais em sentido técnico (que em sua definição aproxima-se do conceito de "prejudicialidade

\footnotetext{
${ }^{354}$ Com efeito, MORTARA deixa clara sua simpatia pela extensão da coisa julgada aos motivos, consoante se pode perceber do seguinte trecho: "i motivi di accoglimento di uma domanda o di uma eccezione, ovvero del suo rigetto, possano valere a dar ragione rispettivamente del rigetto o dell'accoglimento di altra domanda o eccezione, quando il nesso logico e giuridico sai tale che per implicito necessário non si potesse accogliere l'uma senza rigettare l'altra, o viceversa". (Commentario del codice e dele leggi di procedura civile. 4. ed. Milano: Francesco Vallardi Editor, 1923. v. 4, p. 1923).

${ }^{355}$ LIEBMAN, Enrico Tullio. Limites objetivos da coisa julgada, cit., p. 162, com a recomendação de que fosse aplicado "com muita prudência o disposto no parágrafo único do art. 287".

${ }^{356}$ BOTELHO DE MESQUITA, José Ignácio. A autoridade da coisa julgada e a imutabilidade da motivação da sentença, cit., p. 127-129.

${ }^{357}$ BARBOSA MOREIRA, José Carlos. Questões prejudiciais e coisa julgada. Rio de Janeiro: Editor Borsói, 1967. [Apresentada como Tese de Concurso para a docência livre de Direito Judiciário Civil, apresentada à Congregação da Faculdade de Direito da Universidade Federal do Rio de Janeiro].

${ }^{358}$ SANTOS, Moacyr Amaral. Primeiras linhas de direito processual civil, cit., v. 3.
} 
jurídica" formulado por MENESTRINA), independentemente do pedido de declaração incidental. À base de seu raciocínio se encontra o argumento de que a eficácia do julgamento final decorre da concatenação das eficácias das diversas questões prejudiciais de que ele depende, em um raciocínio que põe no mesmo plano a realidade externa à sentença e a sua estrutura interna. A construção, portanto, só é coerente dentro de uma concepção material da coisa julgada que, como vimos mais cedo, não se adapta ao processo civil moderno, e tampouco ao modo como o instituto é regulamentado pelo direito positivo brasileiro. CARMEN AZAMBUJA, de maneira menos elaborada, defende que "os fatos" decididos devem fazer coisa julgada, com fundamento em uma concepção

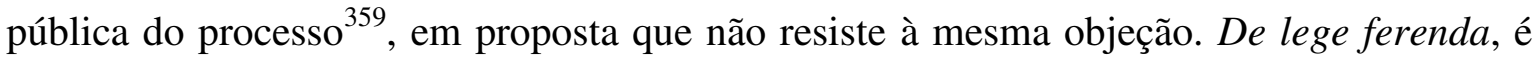
ainda de se registrar a tese de PAUlo RoBERTo DE Oliveira LimA, que defendeu a alteração da lei para que as questões prejudiciais passassem a ser incluídas na coisa julgada, em prol da uniformidade de julgados ${ }^{360}$.

Humberto TheOdoro Junior, em recente artigo, defende tanto a extensão da coisa julgada às questões prejudiciais como a sua ampliação para fora dos limites do objeto do processo $^{361}$, segundo o que seria a diretriz adotada pelo modelo italiano. Mas na realidade, no que diz respeito à Itália, o regime da coisa julgada sobre as prejudiciais não se afasta de maneira significativa daquele que conhecemos no Brasil. É verdade que doutrina e jurisprudência afirmam admitir a formação de coisa julgada sobre algumas prejudiciais, a partir de sua classificação em uma segunda dicotomia: a prejudicialidade técnica (que opera no âmbito de uma mesma relação jurídica) e a prejudicialidade lógica (que existe entre relações jurídicas distintas) $^{362}$. A prejudicialidade técnica, em que se admite a formação de coisa julgada, se constataria naqueles casos em que uma mesma pretensão complexa é deduzida de modo fracionado em juízo; por exemplo, julgada

\footnotetext{
${ }^{359}$ AZAMBUJA, Carmen Luiza Dias de. Rumo a uma nova coisa julgada. Porto Alegre: Livraria do Advogado, 1994. p 162 e ss.

${ }^{360}$ Segundo sustenta o juiz do Tribunal Regional Federal da $5^{\text {a }}$ Região, "restringir a eficácia da coisa julgada ao dispositivo significa abandonar parte do resultado útil do processo, desprezar significativo trabalho produzido pelo Judiciário e multiplicar as possibilidades de decisões conflitantes, militando em desfavor da isonomia e ampliando as oportunidades de gerar perplexidades e desconfianças na atuação do Judiciário" (OLIVEIRA LIMA, Paulo Roberto. Contribuição à teoria da coisa julgada, cit., p. 133). Na realidade, o autor vai além e defende a extensão da coisa julgada a todos os motivos, i.e., a apreciação dos fatos e o raciocínio jurídico desenvolvido, aspecto em que a defesa se aproxima das antigas concepções da coisa julgada como fiç̧ão de verdade. Essa linha de pensamento, como já vimos, é incompatível com os fundamentos da jurisdição moderna, caracterizada pela tutela aos direitos e pelo dualismo do ordenamento, e não pode ser aceita em tão ampla extensão.

${ }^{361}$ THEODORO JÚNIOR, Humberto. Redimensionamento da coisa julgada, cit.

${ }^{362}$ Para uma exposição sistemática do tema, PROTO PISANI, Andrea. Lezioni di diritto processuale civile. 5. ed., cit., p. 332-334; com ampla resenha da jurisprudência peninsular, MENCHINI, Sergio. Il giudicato civile, cit., p. 73-80.
} 
procedente uma demanda de cobrança da prestação principal de um contrato, no segundo processo em que se cobrassem os juros, ou as prestações vincendas, não seria possível discutir a validade da avença. Entretanto, embora se fale em formação de coisa julgada sobre prejudiciais, os casos indicados como de prejudicialidade lógica consistem geralmente em relações estreitas de acessoriedade, traçadas pelo direito material, que em nosso sistema gerariam aquilo que se reconhece como casos de extensão da coisa julgada por implicação lógica (item 3.3.1, retro). A alguns desses casos a nossa lei inclusive faz estender a coisa julgada expressamente, pela técnica do pedido implícito ${ }^{363}$. Já àquilo que se designa de prejudicialidade lógica, que é a prejudicialidade como a estudamos no Brasil, não se reconhece a aptidão de gerar coisa julgada frente às demais relações dependentes. Por isso, a quase cerebrina elaboração doutrinária peninsular parece conduzir a resultados rigorosamente idênticos àqueles que a disciplina mais clara e objetiva da lei brasileira assegura.

Dando eco às manifestações doutrinárias, porém, o Projeto de Lei do Senado no 166, que visa a introduzir um novo Código de Processo Civil, traz em seu art. 490 a regra da extensão da coisa julgada às questões prejudiciais "expressamente decididas",364, com o propósito, declarado na exposição de Motivos, de que o processo "tenha maior rendimento possível". A aptidão do instrumento para lograr esse objetivo parece bastante discutível. A maioria das legislações que optaram pela extensão da coisa julgada às prejudiciais definiu de maneira taxativa as matérias em que isso seria possível (validade do contrato, extinção do crédito por compensação, prescrição, etc.), para que a possível extensão do julgado fosse previamente conhecida pelas partes. O Projeto vai por caminho distinto e admite, de forma ampla e independente da vontade do autor ou do réu, a formação de coisa julgada

\footnotetext{
${ }^{363}$ As situações mais freqüentemente citadas pela doutrina italiana como exemplos de extensão da coisa julgada sobre "prejudiciais em sentido técnico", que são os juros em relação à sentença que reconheceu a obrigação principal e as prestações futuras frente à sentença que reconheceu a relação de trato sucessivo, não representam um problema prático em nosso país, na medida em que o legislador se valeu da técnica do pedido implícito em ambas as matérias. Assim, esses dois efeitos integram o objeto do processo em que se pede o principal, independentemente de demanda da parte (artigos 290 e 293 do Código de Processo Civil). Sobre essa técnica, esclarece MILTON PAULO DE CARVALHO que "pedidos implícitos são os que, embora por sua natureza pudessem constituir pedidos autônomos, a lei considera compreendidos no pedido simples ou qualificado, ou presume neles compreendidos como decorrência objetiva da sucumbência processual"; e exemplifica: "são pedidos implícitos porque a lei os considera compreendidos no pedido simples ou qualificado, por exemplo, as prestações vincendas à época da propositura da demanda, nas obrigações de trato sucessivo, ou execução continuada, como prescreve o artigo 290 do Código de Processo Civil, referindo-se tanto à mora accipiendi quanto à mora solvendi, eis que determina a inclusão, na condenação final, de tais prestações se o devedor não as consignar, no primeiro caso (conf. Art. 892 do mesmo Código), ou as não pagar, no segundo. São ainda pedidos implícitos dessa segunda espécie os juros legais, como vem posto pelo art. 293, $2^{\text {a }}$ parte, do diploma processual" (CARVALHO, Milton Paulo de. Do pedido no processo civil, cit., p. 101-102).

${ }^{364} \mathrm{O}$ texto do projeto artigo 490 é o seguinte: "A sentença que julgar total ou parcialmente a lide tem força de lei nos limites dos pedidos e das questões prejudiciais expressamente decididas"
} 
sobre questões prejudiciais. O inconveniente dessa opção é, justamente, o perigo associado com a adoção da técnica do pedido implícito em larga escala em qualquer matéria: a exceção ao princípio dispositivo gera o risco de perda da previsibilidade e do controle do objeto do processo pelas partes. E isto dá ensejo, de um lado, à formação de coisa julgada sobre questões não suficientemente debatidas, em potencial violação à cláusula do devido processo legal $^{365}$; e de outro lado, estimula o aprofundamento do debate sobre questões acessórias e menos importantes para a solução da causa, justificando mesmo a interposição de recursos pelo vencedor com a finalidade de discutir pontos desfavoráveis da fundamentação cuja conclusão considerou procedente sua pretensão. Tudo isso ocorre, como nem é necessário dizer, em prejuízo à celeridade e à instrumentalidade do processo, objetivos declarados do Projeto.

\subsubsection{A declaração incidental da questão prejudicial}

A exclusão das questões prejudiciais resolvidas pelo juiz do campo de imutabilidade e indiscutibilidade proporcionadas pela coisa julgada material, entretanto, não é absoluta. Isto porque, nos termos do artigo 470 do Código de Processo Civil, se as partes assim o requererem, a resolução dessa questão pode vir a se tornar coberta pela coisa julgada, por meio da chamada ação declaratória incidental. Para isso, a lei estabelece dois outros requisitos: que o juiz seja competente em razão da matéria e que haja relação necessária de prejudicialidade entre a questão incidental e o mérito da causa.

\footnotetext{
${ }^{365}$ Analisando a proposta de alteração, LUIZ GUILHERME PENNACCHI DELLORE pontua que "independentemente da complexidade da causa, muitas vezes há diversos argumentos levantados pelas partes no decorrer do processo que podem ser classificados como questão prejudicial, mas a respeito dos quais pouco ou nenhum debate existe”. E demonstra que “(...) pela proposta de redação do NCPC, se quaisquer dessas questões forem brevemente mencionadas, seja na inicial seja na contestação, e forem apreciadas na sentença, poderão ser cobertas pela coisa julgada, ainda que não haja maior discussão no bojo do processo." (Da ampliação dos limites objetivos da coisa julgada no novo Código de Processo Civil: quieta non movere. Revista de Informação Legislativa, Brasília, ano 48, n. 190, p. 37-38, abr./jun. 2011). O autor ainda registra preocupação com a dificuldade de interpretação da extensão da coisa julgada, pelo fato de permanecer a resolução das questões na motivação da sentença; e com o efeito prático de declaração de inconstitucionalidade com eficácia erga omnes quando a questão da conformidade de lei à Constituição for suscitada em ação civil pública, quando o juiz de primeiro grau se equipararia ao Supremo Tribunal Federal em seu poder de declarar a nulidade da lei. Esta última crítica, de todo pertinente, pode ainda ser estendida a todos os casos em que a questão prejudicial, quando deduzida pela via principal, devesse ser decidida por juiz competente pela matéria. São hipóteses em que atualmente não se admite sequer a ação declaratória incidental, pela inadmissibilidade do cúmulo de pedidos, e que passariam a se servir para subverter a regra de que determinadas questões (como as de família, por exemplo) devam ser conhecidas por um juízo especializado.
} 
O pedido de declaração incidental na realidade é uma ação declaratória, e amplia o objeto da relação processual pela cumulação de uma nova demanda àquela inicialmente proposta $^{366}$ (prejudicial, mas ainda assim uma demanda autônoma). Assim, o artigo 470 não diz respeito a qualquer questão prejudicial, mas somente àquelas que possam constituir causas prejudiciais autônomas, e para isso é necessário que o objeto da declaração pretendida se constitua também, ao menos, em uma relação jurídica ${ }^{367}$. A razão para isso, como se viu, é que a função jurisdicional consiste na aplicação do direito ao caso concreto, de modo que a relação jurídica é a unidade mínima estrutural do processo (item 3.1.2, supra). Dessa forma, as regras do artigo $4^{\mathrm{o}}$ do Código de Processo Civil se aplicam ao pedido de declaração incidente: não é possível pedir a declaração de fatos ou do raciocínio jurídico desenvolvido pelo juiz na formação da decisão, tendo em vista que esses elementos não têm aptidão para adquirir relevância externa ao processo. Para que haja possibilidade jurídica da declaração incidental, é necessário que o pedido comporte efetivo pedido de tutela jurisdicional a uma relação controvertida, ou seja, a questão prejudicial passível de declaração incidente é aquela que seria passível de ser deduzida em juízo como pretensão autônoma, caso em que se estabeleceria relação de prejudicialidade externa entre os processos (art. 265, inciso IV, al. a, do Cód. de Processo Civil).

Dessa forma, o réu em uma ação de cobrança pode pedir a declaração de nulidade do contrato, na medida em que essa segunda pretensão poderia ser objeto de ação autônoma, bem como de influir em outros aspectos da relação jurídica entre as partes: eventual repetição de indébito de parcelas já pagas, anulação de protesto extrajudicial, etc. O que ele não poderia pedir seria a declaração de que o autor foi negligente no curso da relação contratual, pois essa é uma avaliação de fato que somente pode ser feita pelo juiz à vista da conseqüência jurídica pretendida e, principalmente, da norma que lhe serve de fundamento (tomem-se em consideração os diferentes matizes da responsabilidade contratual sob o direito civil, o direito do consumidor, o direito administrativo, etc.). Assim, meros pontos ou questões prejudiciais não podem ser objeto do pedido de declaração incidental. Também o pedido de declaração incidente deve ter por conteúdo

\footnotetext{
${ }^{366}$ BARBOSA MOREIRA, José Carlos. Os limites objetivos da coisa julgada no sistema do novo Código de Processo Civil, cit., p. 95; FABRÍCIO, Adroaldo Furtado. Ação declaratória incidental, cit., p. 66-67.

${ }^{367}$ Conforme assinala WALTER PIVA RODRIGUES, "não cabe o pedido de declaração incidente pelo só fato de existir contestação a uma relação prejudicial. É preciso que essa impugnação corresponda a uma nova pretensão, construindo então uma lide" (Coisa julgada tributária, cit., p. 95). ADROALDO FURTADO FABRÍCIO, no mesmo tom, afirma que "como o da ação declaratória autônoma, o objeto da declaratória incidental é sempre uma relação jurídica. Não o fato simples, ou mesmo o fato jurídico, ou a norma abstrata, mas a relação mesma" (Ação declaratória incidental, cit., p. 73). No mesmo sentido, DINAMARCO, Cândido Rangel. Instituições de direito processual civil, cit., v. 3, p. 233.
} 
estrutural mínimo a relação jurídica, portanto, que lhe proporcione a aptidão de se constituir em causa prejudicial.

Ao pedido de declaração incidental, igualmente, se aplicam os demais requisitos de admissibilidade do cúmulo de demandas em um mesmo processo: os pedidos devem ser compatíveis entre si, o juízo deve ser competente para julgar as duas causas, e também o procedimento deve ser adequado para ambas (artigo 292, $\S 1^{\circ}$, do Código de Processo Civil). Assim, por exemplo, em ação civil pública não é possível pedir a declaração incidental da inconstitucionalidade da lei, porque o Supremo Tribunal Federal tem competência privativa para decidir essa matéria pela via principal, em procedimento específico para essa finalidade. Em ação que visa à percepção de benefício previdenciário deixado pelo de cujus, não é dado pedir a declaração incidental da relação de direito de família, porque a competência material do juízo de família e sucessões não pode ser prorrogada.

\subsection{Amplitude subjetiva da coisa julgada}

A delimitação subjetiva da coisa julgada, isto é, a determinação de quem são os sujeitos perante os quais a sentença se torna imutável e indiscutível, é das aplicações mais importantes da teoria da coisa julgada. Como neste trabalho estamos nos ocupando primordialmente dos aspectos objetivos do instituto, nos limitaremos aqui a traçar uma breve resenha dessa temática ${ }^{368}$, que foi resolvida pelo Código de Processo Civil pela regra do artigo 472 do CPC ("a sentença faz coisa julgada às partes entre as quais é dada, não beneficiando, nem prejudicando terceiros"). De nítida inspiração liebmaniana, a norma não quer dizer que a sentença não irradie efeitos em face de terceiros, o que ela reconhecidamente pode fazer, mas apenas que estes não podem ser juridicamente

\footnotetext{
${ }^{368}$ Para aprofundamento na questão, são valiosos os textos de LIEBMAN - não apenas "Eficácia e autoridade", mas também os seus estudos sobre as ações concorrentes ("Ações concorrentes" e "Pluralidade de partes legítimas à impugnação de um único ato", contidos no mesmo volume de Eficácia e autoridade da sentença e outros escritos sobre a coisa julgada, cit.). Da doutrina nacional recente, valem ser citados a meticulosa tese de JOSÉ ROGÉRIO CRUZ e TUCCI sobre os Limites subjetivos da eficácia da sentença e da coisa julgada civil, cit., o ensaio de EDUARDO TALAMINI a respeito de Partes, terceiros e coisa julgada: os limites subjetivos da coisa julgada. In: DIDIER JR., Fredie; WAMBIER, Teresa Arruda Alvim (Coords.). Aspectos polêmicos e atuais sobre os terceiros no processo civil e assuntos afins. São Paulo: Revista dos Tribunais, 2004, e a dissertação de MARIANA CAPELLA LOMBARDI, ambas apresentadas à Faculdade de Direito da Universidade de São Paulo.
} 
prejudicados pela coisa julgada pela proibição de discutir o conteúdo da sentença em processo futuro.

Historicamente, a admissibilidade da oposição da coisa julgada a terceiros foi objeto de um movimento pendular. No período do processo comum medieval, como vimos anteriormente, a fonte de legitimidade da iudicium não era de origem estatal: a autoridade do julgado provinha da argumentação tópica que o juiz desenvolvia a partir do contraditório que havia se desenvolvido entre as partes. Por essa razão, durante esse período teve larga aplicação a Lex Saepe romana ${ }^{369}$, que limitava a autoridade da coisa julgada às partes, segundo a fórmula "Saepe constitutum est, res inter alios iudicatas aliis non paeiudicare" (Digesto, 42.1.63).

A partir do momento em que se inicia a fase publicística do estudo do processo, porém, o que se coloca em destaque inicialmente é a força de império do Estado ao decidir a lide. A partir da teoria civilista dos atos jurídicos reflexos, ADOLF WACH formula assim a teoria da eficácia reflexa da decisão, segundo a qual os terceiros se submetem irrestritamente à cosia julgada formada em processo alheio, na medida em que a decisão irradie efeitos reflexos sobre seus interesses conexos, ou de forma involuntária ou por ondulação. Nesse ponto tem origem uma corrente de pensamento que é contrária a qualquer limitação subjetiva da coisa julgada, e que viria mais tarde se ajustar à teoria material da coisa julgada, nos moldes da doutrina de ENRICO ALLORIO ${ }^{370}$ ou de GIOVANNI PUGLIESE ${ }^{371}$.

GIUSEPPE CHIOVENDA segue a doutrina de WACH, manifestando o entendimento de que todos devem reconhecer o julgado entre terceiros enquanto tal, sofrendo os efeitos reflexos da decisão. Mas ele faz um importante acréscimo, que suaviza o rigor da tese: os terceiros deveriam reconhecer o julgado entre as partes, mas não poderiam sofrer prejuízo jurídico. A partir desse princípio, ele distingue os terceiros totalmente indiferentes, que não podem impedir a formação da sentença ou a ela se opor, devendo simplesmente reconhecer o julgado; os terceiros que não têm de reconhecer o julgado por serem titulares de relação incompatível e estarem sujeitos a prejuízo jurídico, que podem intervir no processo ou se

\footnotetext{
${ }^{369}$ No tocante à delimitação subjetiva da coisa julgada, os glosadores e comentadores, consoante assere Pugliese, reconheceram o mérito das proposições dos juristas romanos. Na glosa de Acúrsio à lex Saepe, é reafirmado o princípio segundo o qual a sentença não prejudica e tampouco beneficia terceiros; e, outrossim, vêm catalogadas, ao lado daquelas enumeradas por Macro, várias outras situações nas quais tal disposição não prevalecia" (CRUZ E TUCCI, José Rogério. Limites subjetivos da eficácia da sentença e da coisa julgada civil, cit., p. 50).

${ }^{370}$ ALLORIO, Enrico. La cosa giudicata rispetto ai terzi, cit., p. 60 e ss.

${ }^{371}$ PUGLIESE, Giovanni. Giudicato civile: diritto vigente, cit., p. 884.
} 
oporem à sentença; e os terceiros que têm de reconhecer o julgado por serem titulares de relação compatível e dependente, que podem assim intervir como assistentes e se opor limitadamente à sentença ${ }^{372}$.

Em 1935, vem a lume a teoria de Liebman, que distingue pela primeira vez a eficácia natural da sentença e a autoridade da coisa julgada que proporciona a sua estabilidade (item 3.2.3 retro). O valor dessa sistematização, mais do que no notável resultado da apuração de conceitos, está no restabelecimento do tratamento equitativo que ela permitiu dos terceiros frente aos resultados do processo. Uma vez que tenha ficado estabelecido que a coisa julgada e a eficácia da sentença eram fenômenos de natureza distinta, não havia obstáculo para que se admitisse que eles pudessem variar em extensão, ou seja: a extensão subjetiva da eficácia da sentença não coincide com a extensão da coisa julgada.

Assim, desde que se reconhece a jurisdição como função pública, e "uma vez que o juiz é o órgão ao qual atribui o Estado o mister de fazer atuar a vontade concreta da lei no caso concreto, apresenta-se sua sentença como eficaz exercício dessa função perante todo o ordenamento jurídico e todos os sujeitos que nele operam"373. Dessa forma, os efeitos da sentença têm projeção erga omnes, subordinando a todos que vivem sob as leis do Estado. É claro, no entanto, que o modo como essa eficácia se fará sentir sobre cada um variará a depender da natureza de seu interesse frente ao objeto da causa. "Enquanto, abstratamente, estão todas as pessoas submetidas à eficácia da sentença, praticamente lhe sofrem os efeitos aqueles em cuja esfera jurídica entra mais ou menos diretamente o objeto da sentença: assim, antes de tudo e necessariamente, as partes, titulares da relação afirmada e deduzida em juízo, e, depois, gradativamente, todos os outros cujos direitos estejam de certo modo com ela em relação de conexão, dependência ou interferência jurídica ou prática, quer quanto a sua existência, quer quanto à possibilidade de sua efetiva realização. A natureza dessa sujeição é para todos, partes ou terceiros, a mesma; a medida da sujeição determina-se, ao revés, pela relação de cada um com o objeto da decisão. Entre as partes e terceiros só há esta grande diferença: que para as partes, quando a sentença passa em julgado, os seus efeitos se tornam imutáveis, ao passo que para os terceiros isso não acontece $^{, 374}$.

\footnotetext{
${ }^{372}$ CHIOVENDA, Giuseppe. Instituições de direito processual civil, cit., v. 1, p. 421-422.

${ }^{373}$ LIEBMAN, Enrico Tullio. Eficácia e autoridade da sentença, cit., p. 123.

${ }^{374}$ LIEBMAN, Enrico Tullio. Eficácia e autoridade da sentença, cit., p. 125.
} 
Dessa forma, a teoria formulada por LIEBMAN permitiu um tratamento equitativo aos terceiros que, sendo titulares de relações que dependam do julgado alheio, sofram prejuízo jurídico com o resultado do processo. Pois embora estejam eles sujeitos à eficácia da sentença, a coisa julgada não lhes pode ser oposta, e assim é resguardado a qualquer tempo o direito de, em processo autônomo, demonstrarem a injustiça da decisão ${ }^{375}$. Essa faculdade não é aberta, entretanto, a todos os terceiros praticamente prejudicados pela sentença, mas apenas àqueles que, por serem titulares de direitos ligados ao objeto da demanda alheia por nexo de prejudicialidade e dependência, se qualifiquem como nela juridicamente interessados ${ }^{376}$. A limitação da coisa julgada às partes, assim, afirma-se como decorrência do princípio do contraditório, a "alma mesma do processo", pois aqueles que não tiveram oportunidade de deduzir suas razões em juízo não poderiam ser prejudicados em suas esferas jurídicas pela estabilidade da sentença ${ }^{377}$.

Outro problema tormentoso, em que a teoria de LIEBMAN se mostrou de grande valor prático foi a definição da abrangência da coisa julgada nas ações concorrentes, mais precisamente o caso do concurso subjetivo, caracterizado por pluralidade de partes legitimadas - por direito próprio - a impugnar um único ato. É a situação que se tem quando o sócio pretende anular uma deliberação da sociedade, ou quando o cidadão pretende questionar um ato administrativo como um edital de licitação ou de concurso público. Aplicando-se a sua teoria, que confere ampla extensão aos efeitos da sentença restringindo a imutabilidade às partes, segue a consequiência de que a pretensão movida por qualquer um dos legitimados poderia ser julgada improcedente sem prejudicar as ações de outros sócios, pois a coisa julgada se restringe às partes do primeiro processo. De outro lado, sendo ela julgada procedente, os efeitos da sentença obtida contra a sociedade se irradiarão sobre todos os demais sócios. Aí haverá prejuízo às demais pretensões concorrentes, não porque a coisa julgada se estenda sobre elas, mas porque, convergindo para um único ponto todas as pretensões individuais, a eficácia da primeira sentença comprometerá o interesse processual nos pedidos posteriores.

Como se sabe, BARBOSA MOREIRA levantou crítica a essa orientação de LIEBMAN, chamando atenção para a situação dos sócios interessados na manutenção da decisão, que a seu ver poderiam posteriormente mover ação pretendendo a declaração de validade da deliberação anulada. Para evitar o conflito prático de julgados, a única solução que a lei

\footnotetext{
${ }^{375}$ LIEBMAN, Enrico Tullio. Eficácia e autoridade da sentença, cit., p. 139-140.

${ }^{376}$ LIEBMAN, Enrico Tullio. Eficácia e autoridade da sentença, cit., p. 143.

${ }^{377}$ MOTELEONE, Girolamo. I limitti soggettivi del giudicato civile. Padova: CEDAM, 1978. p. 150-151.
} 
poderia adotar seria a extensão da coisa julgada da primeira demanda a todos os demais sócios $^{378}$. Também AdA PELlEgRINI GRINOver adere a essa crítica ${ }^{379}$. O equívoco da crítica, em nosso modo de pensar, está em que o interesse em manter a deliberação social é de titularidade da sociedade, de modo que qualquer sócio somente pode ter eventual interesse indireto em sua manutenção. Por isso, a legitimidade para defender a manutenção da deliberação é da própria sociedade e apenas dela, podendo os sócios com interesse jurídico caracterizado eventualmente intervirem na ação anulatória como assistentes. Ou seja: os sócios insatisfeitos não têm a legitimidade para promover essa ação declaratória de validade da deliberação, o que pressuporia uma capacidade de substituir em juízo a sociedade que eles não detêm. Sua posição é diferente, do ponto de vista material, em relação àquela do sócio que sustenta que teve direito violado pela deliberação social. O que lhes seria resguardado, no entanto, seria promover demanda que visasse a proteger interesse próprio ligado por nexo de dependência jurídica à deliberação anulada, em que poderiam demonstrar - de forma incidental - a injustiça daquela primeira sentença.

Em recente tese, o professor JosÉ ROGÉRIO CRUZ E TUCCI sustenta que, ao contrário do que sugere a redação do art. 472 do CPC, a coisa julgada pode sim beneficiar terceiros. Isto não decorre, contudo, de um vínculo direto imposto pela coisa julgada, mas sim da falta de interesse processual do terceiro em impugnar a decisão que lhe tenha sido favorável. Como se retira da própria argumentação do autor, assim, a extensão da coisa julgada benéfica a terceiros não parece ser mais do que aparente. De qualquer forma, justamente pela ausência de interesse dos indivíduos em contestar algo que lhes é favorável, salvo melhor juízo, a questão não apresenta maior interesse prático.

Há poucos anos, foi formulada por JosÉ MARIA TESHEINER uma crítica à teoria de LiEBMAN, no aspecto em que defende existir uma diferença de extensão entre a coisa julgada, restrita às partes; e a eficácia da sentença, oponível contra todos ${ }^{380}$. Parte o professor gaúcho do pressuposto de que antes dessa construção prevaleceria a orientação de que os terceiros em nenhuma hipótese poderiam ser prejudicados pela sentença, e diz que a construção contida em "Eficácia e autoridade", na prática, teria sido responsável por estender a coisa julgada aos terceiros indiretamente interessados, dada a dificuldade de

\footnotetext{
${ }^{378}$ BARBOSA MOREIRA, José Carlos. Litisconsórcio unitário, cit., p. 143-145.

${ }^{379}$ GRINOVER, Ada Pellegrini. Notas a "Ações concorrentes" e "Pluralidade de partes legítimas à impugnação de um único ato", cit., p. 229-239.

${ }^{380}$ A crítica foi publicada na monografia Eficácia da sentença e coisa julgada no processo civil, cit. e no artigo Autoridade e eficácia da sentença: crítica à teoria de Liebman. Revista dos Tribunais, São Paulo, n. 744, abr. 2000.
} 
prova da "injustiça da decisão" pelo prejudicado. De forma complementar, analisa diversas situações de titularidade de direitos dependentes daquele discutido na demanda, para defender sua presença obrigatória no processo por litisconsórcio necessário. EDUARDO TALAMINI endossou parcialmente essa proposta, sugerindo de lege ferenda a citação de todos os legitimados concorrentes para, em o querendo, ingressarem em um dos pólos da relação processual e assim se submeterem à coisa julgada ${ }^{381}$.

A crítica não procede, contudo. TESHEINER parte já de um erro ao estabelecer suas premissas, ao afirmar que antes da teoria de LIEBMAN não era aceito que os efeitos da sentença em hipótese nenhuma poderiam atingir terceiros. Ao contrário, a teoria da eficácia reflexa admitia normalmente que terceiros indiretamente interessados na causa fossem prejudicados, sem que qualquer meio lhes fosse aberto para defender seus interesses de forma autônoma: tais são as posições de ADOLF WACH, de ENRICO ALLORIO e de Giovani Pugliese, que passamos em revista mais cedo. Tanto os efeitos da sentença como a coisa julgada, na realidade almagamados em um único conceito, impunham-se aos terceiros. Por isso, ao contrário de agravar a situação dos terceiros, a contribuição de LIEBMAN veio a lhes resguardar com a possibilidade de demonstrar a injustiça do julgamento da causa a que se encontravam subordinados seus interesses. Mas o que resulta claro de sua crítica, na realidade, é o entendimento de que aqueles que possam ser potencialmente prejudicados pela sentença devem figurar sempre como partes no processo, independentemente de serem titulares da relação que constitui objeto do processo. $\mathrm{O}$ problema aí é outro: TESHEINER deseja desvincular a legitimidade ad causam da titularidade da relação jurídica sobre a qual versa o processo, para estendê-la também às situações dependentes, em uma ampla expansão da legitimidade extraordinária fundada na titularidade de interesse dependente. A dificuldade está em que as relações de dependência e prejudicialidade que se estabelecem entre direitos subjetivos variam imensamente tanto em intensidade como em número, constituindo um catálogo infindável e de impossível sistematização. Ainda que vá gradualmente diminuindo essa intensidade, fato é que as repercussões de cada pretensão sobre as relações conexas tendem ao infinito. Nesse contexto, seria impossível determinar a extensão desse litisconsórcio necessário. A ser levada para a prática, de resto, a proposta poderia gerar os maiores inconvenientes. Basta imaginar que, no processo em que se discuta a nulidade de determinada cláusula de edital em concurso público, a repercussão da procedência obtida contra a administração pública

\footnotetext{
${ }^{381}$ TALAMINI, Eduardo. Partes, terceiros e coisa julgada: os limites subjetivos da coisa julgada, cit., p. 211.
} 
(única legitimada passiva pela regra atual) pode repercutir na esfera de milhares de candidatos interessados na manutenção daquela regra. E se é certo que alguns deles podem intervir como assistentes do ente público, seria um exagero, verdadeiramente inviabilizador do processo, pretender que todos eles figurassem como litisconsortes necessários.

\subsubsection{Os adquirentes do bem litigioso e a coisa julgada}

Há alguns terceiros, diretamente interessados no objeto do processo, que excepcionalmente se submetem à coisa julgada da mesma maneira que as partes, tanto em benefício como em prejuízo de seus interesses. Trata-se dos adquirentes do direito litigioso, ou aventi causa, que sucedem as partes na titularidade da relação jurídica que constituiu objeto do processo. Como esclarece EDUARDO TALAMINI, “com a sucessão, são transferidas todas as posições jurídicas relativas ao objeto da sucessão (universal ou singular), inclusive as de caráter processual, como é a coisa julgada. Nesse sentido, o sucessor não detém a qualidade de terceiro. Ele assume as próprias posições materiais e processuais do sucedido, nos limites da sucessão" ${ }^{382}$. O adquirente de um imóvel sobre o qual foi constituída uma servidão por decisão judicial, por exemplo, não poderá rediscutir no futuro a sentença formada contra o alienante. A sucessão, quando ocorrida após a formação da coisa julgada, não dá margem para dúvidas quanto à sua extensão ao sucessor $^{383}$.

Os problemas se dão quanto à sucessão do direito litigioso enquanto o processo estiver em curso. Na sucessão a título universal, que ocorre quando da extinção da personalidade pela morte do indivíduo ou pela liqüidação da pessoa jurídica, o espólio ou a massa assumirão o pólo do processo em que se encontrava o sucedido, tornando-se partes que se sujeitarão normalmente à coisa julgada. Mas na sucessão a título singular, a lei prevê que por regra se manterá no processo o alienante (artigo 42 do Código de Processo Civil), que atuará então como substituto processual do novo titular do direito controvertido, que por sua vez ficará vinculado à sentença e à coisa julgada (artigo 42, $\S 3^{\circ}$ ). O adquirente tem a oportunidade de intervir no processo, assumindo a qualidade de

\footnotetext{
${ }^{382}$ TALAMINI, Eduardo. Partes, terceiros e coisa julgada: os limites subjetivos da coisa julgada, cit., p. 219.

${ }^{383}$ CRUZ E TUCCI, José Rogério. Limites subjetivos da eficácia da sentença e da coisa julgada civil, cit., p. 225-226.
} 
parte se houver a concordância da parte contrária $\left(\S 1^{\circ}\right)$ ou, caso contrário, intervindo como assistente litisconsorcial $\left(\$ 2^{\circ}\right)^{384}$.

Nesse caso, a doutrina e a jurisprudência vêm temperando o rigor da lei para somente autorizar a extensão da coisa julgada ao adquirente nos casos em que for presumível que ele tivesse conhecimento de que a coisa era litigiosa ${ }^{385}$, em tendência análoga àquela que se verifica nos demais casos de substituição processual.

\subsubsection{A substituição processual e a coisa julgada}

Para mais além dos terceiros juridicamente interessados, a questão da extensão subjetiva do julgado se coloca de maneira mais sensível para os terceiros diretamente interessados no objeto da sentença. Ou seja, trata-se da delicada temática que concerne à vinculação do titular do direito material, que não participou do processo porque seus interesses foram defendidos em juízo por um substituto processual legitimado pela lei de forma extraordinária, ao eventual resultado desfavorável do julgamento.

Tradicionalmente, a doutrina defende que a coisa julgada se estende ao substituído, seja por se considerar que este, como titular da relação de direito material, é "parte" para os efeitos do art. 472 do CPC, seja por se entender que a substituição exige segurança quanto à vinculação do interesse nela discutido aos resultados do processo. É a posição sustentada, entre outros, por DONALDO ARMELIN ${ }^{386}$,

\footnotetext{
${ }^{384}$ Contra, CARLOS ALBERTO ALVARO DE OLIVEIRA, para quem a intervenção adesiva do adquirente se dá também na qualidade de parte. (Alienação da coisa litigiosa. 2. ed. Rio de Janeiro: Forense, 1984). A discussão a respeito da qualidade em que os intervenientes atuam no processo dependerá do conceito que se tiver de parte processual, conceito controvertido na doutrina, que se polariza entre defini-las como os sujeitos que moldaram o processo no momento de sua formação (CHIOVENDA) e aqueles que nele atuam, a qualquer tempo, como sujeitos do contraditório (LIEBMAN).

${ }^{385}$ TALAMINI, Eduardo. Partes, terceiros e coisa julgada: os limites subjetivos da coisa julgada, cit., p. 220221; CRUZ E TUCCI, José Rogério. Limites subjetivos da eficácia da sentença e da coisa julgada civil, cit., p. 225-226. No âmbito do Superior Tribunal de Justiça, a partir do julgamento do recurso especial $\mathrm{n}^{\circ}$ 53.480/SP firmou-se orientação jurisprudencial no sentido de que "o terceiro adquirente de imóvel, a título oneroso e de boa fé, não é alcançável por decisão em processo em que não fora parte" (Quarta Turma, rel. Min. FONTES DE ALENCAR, j. 26.02.1996, p. DJ 06.05.1996). Especificamente no que diz respeito ao processo executivo, a Lei $\mathrm{n}^{\circ} 11.232 / 2006$ veio a resguardar a boa fé do terceiro adquirente com a previsão de que a fraude à execução somente se presumirá se houver averbação da distribuição da execução em curso averbada junto à matrícula, previamente à alienação (at. 615-A do Código de Processo Civil). No que diz respeito à alienação no curso de processo de conhecimento, a orientação persiste a ser a da investigação da boa fé a partir do exame das circunstâncias do caso concreto.

${ }^{386}$ ARMELIN, Donaldo. A legitimidade para agir no direito processual civil brasileiro, cit., p. 134.
} 
EPhraim de CAMpos JR. ${ }^{387}$, ARAKen de Assis ${ }^{388}$, MARA Síllia GaZzi ${ }^{389}$, Edson FERreira DA Silva ${ }^{390}$, José Augusto Delgado ${ }^{391}$, entre outros. Mas essa posição vem sendo atenuada, à vista da influência do princípio constitucional do devido processo legal e do contraditório. EDUARDO TALAMINI prefere adotar uma situação intermediária, aceitando em princípio que a coisa julgada se estenda ao substituído, mas condenando a "afirmação generalizada" dessa orientação ${ }^{392}$, pois isso somente poderia ocorrer desde que o substituto houvesse tido a oportunidade de figurar como parte no processo, que tivesse ciência (ou devesse ter, sob critérios de diligência média) da existência do processo, e que lhe fosse aberta oportunidade de nele intervir como assistente em o querendo. JOSÉ ROGÉRIO CRUZ E TUCCI segue a mesma trilha, afirmando que onde não concorrerem esses requisitos mínimos, "deve-se vedar a comunicação da coisa julgada ao substituído"393

O que se verifica nessa questão é que as relações entre substituto e substituído, isto é, as situações legitimantes que estão na base de cada um desses variados casos de legitimação extraordinária diferem de forma significativa no que diz respeito à intensidade do nexo que existe entre um e outro. Assim, por exemplo, parece adequado que o adquirente do direito litigioso, que segue representado até o final do processo pelo alienante (art. 42, CPC), fique vinculado à coisa julgada do processo, mesmo que opte por nele não intervir como assistente litisconsorcial. A intensidade do vínculo negocial, que pressupõe negociação entre as com plena informação e esclarecimento sobre os riscos que pesam sobre o bem, de regra fornece um substrato material que torna razoável essa extensão da coisa julgada ao terceiro (entretanto, como visto no item anterior, onde não se

\footnotetext{
387، “....) o substituído permanece concretamente sujeito aos poderes do órgão jurisdicional, e é na sua esfera jurídica que se produzirão os efeitos do exercício de tal poder, e em particular, a sujeição à coisa julgada" (CAMPOS, Ephraim de. Substituição processual. São Paulo: Ed. Revista dos Tribunais, 1985).

388،o substituído somente revela-se terceiro formalmente; na verdade, é parte no sentido material (rectius: sujeito da lide), porque titular do objeto litigioso e, em virtude dessa inconcussa qualidade, atingido pela eficácia própria do provimento" (Substituição processual. Revista Síntese de Direito Civil e Processual Civil. Porto Alegre, v. 5, n. 26, p. 61, nov./dez. 2003).

389، A primeira parte do art. 472 do CPC fala em 'partes'. Não adjetiva-as. Ora o substituído é, ainda que em sentido material, “'parte”. E é como parte (em sentido material) que ele vem a ser atingido pela coisa julgada. Logo, continua consagrada a regra do valor inter partes da coisa julgada ainda na hipótese de substituição processual” (GAZZI, Mara Silvia. Os limites subjetivos da coisa julgada. Revista de Processo, São Paulo, n. 36, p. 110, out./dez. 1984).

${ }^{390}$ SILVA, Edson Ferreira da. Da legitimação extraordinária, inclusive na Constituição de 1988. Revista de Processo, São Paulo, n. 64, p. 80-91, out./dez. 1991.

391،Em torno da substituição processual não há lugar para se entender que a coisa julgada material sofra qualquer restrição. A sentença dada ao substituto vale também para o substituído. Os seus efeitos ficam dentro dos limites subjetivos da coisa julgada, pois não haveria segurança jurídica se o substituído tivesse liberdade para rediscutir a coisa julgada material" (DELGADO, José Augusto. Aspectos controvertidos da substituição processual. Revista de Processo, São Paulo, n. 47, p. 13, jul./set. 1987).

${ }^{392}$ TALAMINI, Eduardo. Partes, terceiros e coisa julgada: os limites subjetivos da coisa julgada, cit., p. 223.

${ }^{393}$ CRUZ E TUCCI, José Rogério. Limites subjetivos da eficácia da sentença e da coisa julgada civil, cit., p. 232.
} 
puder presumir razoavelmente o conhecimento do adquirente, a coisa julgada não lhe será aplicável). O mesmo raciocínio aplica-se aos condôminos de bem indivisível (art. 1.314, Cód. Civil) ${ }^{394}$; também aí se pressupõe que a defesa em juízo do bem comum, quando levada a efeito por apenas um dos condôminos, tenha sido feita de comum acordo e com o conhecimento dos demais. No caso específico do processo coletivo, em que os critérios formais que asseguram a legitimação não fornecem indicação sobre a intensidade do nexo que liga o legitimado à classe substituída (art. 82 da Lei $n^{\circ}$ 8.078/90), não é possível presumir que o autor coletivo conte com o conhecimento ou anuência dos substituídos, de maneira que não se mostra adequada a extensão da coisa julgada a suas esferas jurídicas.

Em conclusão, parece difícil dar resposta peremptória à questão de se os substituídos se vinculam à coisa julgada formada no processo movido pelo substituto. Dada a heterogeneidade das situações legitimantes, e a diversidade na intensidade do vínculo pelo qual a lei autoriza o substituto agir em juízo para defender o interesse do substituído, essa resposta somente pode ser dada à vista de cada hipótese de substituição processual.

\subsection{Conseqüências da violação à coisa julgada}

Neste último tópico, trataremos brevemente das consequiências da violação à coisa julgada. Esse tema é bem regulamentado pelo direito processual positivo, que foi estruturado de acordo com a natureza processual do instituto.

No que diz respeito ao tema da violação da coisa julgada pela conduta extraprocessual das partes, não abordaremos a questão neste capítulo porque esse

\footnotetext{
${ }^{394}$ Registre-se que EDUARDO TALAMINI entende não haver substituição processual em diversas das hipóteses usualmente apontadas desse instituto no direito brasileiro, como nas ações movidas por um dos co-credores para exigir a obrigação indivisível, naquelas movidas pelos credores solidários para exigir a obrigação por inteiro, naquelas em que condômino para promove a defesa do bem comum, ou o herdeiro para defende a herança, naquelas em que o co-titular do direito ameaçado ou violado impetra mandado de segurança, ou naquelas em que os sócios promovem a ação de responsabilidade do administrador da sociedade anônima. Isso seria assim por não existir "regra que preveja haver substituição processual nos casos acima citados (...); as normas em questão limitam-se a afirmar que cada um dos co-titulares está legitimado a isoladamente promover a defesa judicial do direito comum" (Partes, terceiros e coisa julgada: os limites subjetivos da coisa julgada, cit., p. 211). O raciocínio é verdadeiramente paradoxal, na medida em que o que define a substituição processual (conferindo-lhe especialidade em relação à legitimação extraordinária em sentido amplo, cf. anota BARBOSA MOREIRA no ensaio Apontamentos para um estudo sistemático da legitimação extraordinária. In: Direito processual civil: ensaios e pareceres. Rio de Janeiro: Editor Borsói, 1971. p. 58-72) é justamente a defesa isolada do direito alheio - e o direito comum é ao mesmo tempo direito próprio $e$ direito alheio - em nome próprio.
} 
fenômeno não é compatível com a teoria processual da coisa julgada, que a define como vínculo dirigido aos juízes em futuros processos em que se apresente a mesma lide que uma vez foi decidida. Isso não quer dizer que as partes não possam contrariar os efeitos da sentença, praticando atos jurídicos certamente ilícitos e passíveis de anulação sob as regras do direito civil, ou mesmo de responsabilização civil de natureza indenizatória ou punitiva. Por exemplo, alguém que venha a protestar documento de crédito derivado de cláusula contratual cuja nulidade foi declarada em juízo, desconsiderando o vínculo que lhe foi imposto pela eficácia declaratória da sentença, terá praticado ilícito civil para o qual há pena específica: a de ficar obrigado a pagar multa equivalente àquilo tiver exigido do segundo indivíduo (art. 940, Cód. Civil). De um modo geral, os atos que contrariarem os efeitos das sentenças, sejam eles declaratórios, constitutivos ou condenatórios, incorrerão em ilicitude de objeto, e serão assim nulos (art. 166, inc. II, Cód. Civil). Mas não haverá violação à coisa julgada, propriamente dita, na medida em que esta consiste em um instituto direcionado aos juízes e funcionalizado à estabilidade da prestação jurisdicional. O que se deve ressalvar é que, caso a contrariedade aos efeitos da sentença por uma das partes dê origem a um novo processo, a mesma questão já decidida não poderá ser invocada pelo infrator a fim de justificar sua conduta. Aí sim se manifestarão os efeitos ativo e negativo da coisa julgada.

\subsubsection{Na apreciação de questão prejudicial}

A violação à coisa julgada na apreciação de coisa julgada se dá pela desconsideração do efeito ativo da coisa julgada, que consiste na indiscutibilidade da questão já decidida sempre que ela surgir como um dos elementos a serem considerados na resolução do mérito de uma demanda distinta daquela que deu origem à coisa julgada. Tratando-se de demanda distinta, ou seja, de relação processual caracterizada por pedido e causa de pedir distintos, a coisa julgada anterior não se colocará como óbice à válida instauração da relação processual. O processo poderá prosseguir até a decisão de mérito, mas nesse momento, o juiz estará vinculado por uma regra de procedimento que lhe impede de reabrir a discussão em torno da questão prejudicial que constituiu objeto autônomo do primeiro processo. 
A sentença que contrariar essa prescrição será nula, em razão da violação ao artigo 467 do Código de Processo Civil. Percebe-se que, com isso, o vencedor do primeiro processo goza de um nível de proteção mais intenso que o de que se considerasse a coisa julgada um instituto qualquer de direito material, que levasse a discussão a respeito do processo já decidido para o âmbito das questões de mérito. Essa nulidade processual não será pronunciada, contudo, se o mérito da causa ainda assim tiver sido decidido em favor da parte a quem aproveitava o julgado anterior (art. $249, \S 2^{\circ}$, do CPC).

\subsubsection{No novo julgamento de demanda reiterada}

A contrariedade à coisa julgada também pode ocorrer pelo novo julgamento de uma demanda reiterada, ou seja, em desrespeito ao efeito negativo da coisa julgada, que se irradia como um pressuposto impeditivo à validade da instauração e desenvolvimento da nova relação de direito processual (artigos 331, inciso VI, e 267, inciso V, do Código de Processo Civil). A eventual a sentença que julgue novamente a demanda idêntica será contaminada pela nulidade do processo, de modo que o tribunal, ao julgar o recurso, pode determinar de pronto a extinção do processo sem resolução de mérito, independentemente de alegação das partes, por se tratar de norma de ordem pública.

As nulidades processuais, contudo, estão sujeitas ao efeito sanatório geral da coisa julgada formal após o trânsito em julgado da decisão, de modo que se essa nulidade não vier a ser pronunciada em sede de recurso, também ela ficará sujeita à preclusão sobre o deduzido e o dedutível (Art. 474 do Código de Processo Civil). Isto significa que, na hipótese de serem proferidas duas sentenças de mérito sobre uma mesma pretensão, em razão de ter sido ela reiterada, irá prevalecer a segunda sentença. Coerente com esses princípios, o artigo 485, inciso IV, do Código de Processo Civil submete à rescisão a sentença que houver violado a coisa julgada, estando nisso implícito que, esgotado o respectivo prazo decadencial, será ela que regulamentará em definitivo o mérito da lide ${ }^{395}$.

\footnotetext{
${ }^{395}$ Conforme argumenta CÂNDIDO RANGEL DINAMARCO, “a oferta do caminho da ação rescisória significa que o sistema processual não pretendeu que a segunda sentença passada em julgado fosse simplesmente desconsiderada, instável ou ineficaz" (Instituições de direito processual civil, cit., v. 3, p. 335-336). Em sentido contrário, TEREZA ARRUDA ALVIM WAMBIER sustenta que "o manejo da ação rescisória, neste caso, apesar da letra fria da lei, é prescindível. Na verdade, já que se trata de sentença juridicamente inexistente, que não tem aptidão para transitar em julgado, nada há a desconstituir. Há, isto sim, única e exclusivamente, uma situação de inexistência jurídica a se declarar, por meio da ação que não
} 


\subsection{Transição}

Neste capítulo, buscamos fazer uma revisão da teoria da coisa julgada no processo civil tradicional. E tendo em conta que o propósito final desta dissertação é analisar a maneira pela qual a sentença genérica coletiva dimensiona a coisa julgada, optamos por analisar inicialmente os condicionamentos que a organização política do Estado constitucional impõe à teoria do processo. Esses condicionamentos, de fato, representam um limite à elasticidade conformativa do instituto, que será igualmente aplicável à coisa julgada tal como regulamentada pelo Código de Processo Civil, ou por qualquer outra lei especial. Vimos que o processo moderno é ramo do direito público, que se volta à aplicação do direito, em uma atividade eminentemente declarativa. Ele é preordenado à tutela de direitos, razão pela qual sua entidade mínima estrutural é a relação jurídica concreta, que não pode ser fracionada em seus elementos, em um limite material ao princípio dispositivo. Por congruência, o objeto mínimo da coisa julgada também deve corresponder à decisão sobre a pretensão, à vista dessa mesma relação jurídica. E assim, como pode o instituto da coisa julgada se adaptar à sentença proferida em um procedimento no qual a cognição não exaure esse objeto mínimo, se é que ele pode, é a questão que será reservada ao capítulo final deste trabalho.

fica sujeita a um lapso pré-definido para ser movida" (Nulidades do processo e da sentença. 6. ed. São Paulo: Ed. Revista dos Tribunais, 2007. p. 380). Essa posição não nos parece sustentável. A autora parte da premissa de que a reiteração de demanda consiste em hipótese de carência de ação, por falta de interesse processual, e deduz daí a inexistência da sentença, confundindo os elementos essenciais do ato judicial com os seus elementos acidentais. Não considera, ainda, a hipótese de que a violação da coisa julgada se dê na apreciação da questão prejudicial já decidida em outro processo, situação em que é evidente o interesse processual do autor em pedir coisa diversa, bem como a inexistência de qualquer óbice à formação da relação processual: tudo o que existe é uma regra de julgamento imposta pela regra da indiscutibilidade. De resto, a indevida ampliação da categoria da inexistência jurídica da sentença, presente na obra da processualista paulista, resulta como um artifício que produz o resultado prático de possibilitar a reabertura do processo mediante a rediscussão de aspectos formais do procedimento, em clara violação à regra da preclusão do deduzido e do dedutível, que fomenta a insegurança das partes na fruição do bem jurídico que lhe foi reconhecido pela sentença. 


\section{A COISA JULGAdA SOBRE A SENTENÇA GENÉRICA COLETIVA}

\subsection{Enquadramento dogmático da sentença genérica coletiva}

Se a coisa julgada não tem dimensões próprias, mas as dimensões dos efeitos da sentença ${ }^{396}$, o próximo passo na análise da coisa julgada sobre a sentença genérica coletiva criada pelo artigo 95 do Código de Defesa do Consumidor deve ser a análise da estrutura que a distingue de outras decisões judiciais. De fato, na linha do que fala RODOLFO DE CAMARgo MANCUSO, "a coisa julgada nas ações coletivas apresenta-se como um posterius, em relação ao binômio formado pela natureza do interesse e pelo contingente de sujeitos aí subjacente", de modo que "não tem sentido lógico proceder a contrariu sensu, primeiro indagando sobre a coisa julgada, para depois aferir sua aplicabilidade ao objeto litigioso e aos sujeitos",397.

A compreensão da maneira pela qual se manifesta essa coisa julgada "dimensionada" pelo objeto coletivo exige, assim, o prévio estabelecimento daquilo que poderíamos chamar de um "estudo anatômico" da sentença genérica coletiva, em que se identifique precisamente qual o seu conteúdo e seu objeto de decisão, a ser posteriormente ser analisado sob as óticas dos condicionamentos estruturais que a jurisdição moderna impõe à teoria da coisa julgada e das regras de direito positivo pertinentes ao instituto.

Dessa forma, nas próximas linhas estudaremos a características da sentença genérica coletiva, buscando encontrar o seu enquadramento dogmático. Examinaremos então em que medida ela se distancia de uma sentença de mérito comum, para que aí possamos tratar, propriamente, da coisa julgada coletiva.

\footnotetext{
${ }^{396} \mathrm{Cf}$. DINAMARCO, Cândido Rangel. Instituições de direito processual civil. Instituições de direito processual civil, cit., v. 1, p. 310.

${ }^{397}$ Ação civil pública: em defesa do meio ambiente, do patrimônio cultural e do consumidor. $12^{\mathrm{a}}$ ed., São Paulo: Revista dos Tribunais, 2011, p. 351.
} 


\subsubsection{Processo parcial e sentença parcial}

No primeiro capítulo desta dissertação, examinamos a fragmentação da atividade cognitiva que caracteriza o procedimento especial da ação civil coletiva, técnica pela qual se divide a análise das questões pertinentes à tutela dos direitos individuais em causa em dois momentos distintos: um primeiro processo em que se abordam coletivamente as questões comuns à classe, que culmina em uma sentença genérica coletiva; e um segundo, em que se abordam de forma particularizada as questões individuais pertinentes a cada indivíduo substituído.

A sentença coletiva tem seu objeto restrito à parcela homogênea, compartilhada por uma coletividade de indivíduos, de interesses individuais gerados por uma lesão "de massa”. Ela se restringe ao núcleo de homogeneidade desses direitos individuais, sem examinar a margem de heterogeneidade que deve ser objeto de conhecimento em processos complementares de habilitação e liqüidação. Dessa forma, o que se tem na sentença genérica coletiva é uma decisão de mérito, definitiva, mas que não se estende sobre todo o direito deduzido em juízo. E de maneira muito particular, ela deixa de determinar o efeito jurídico dos fatos discutidos (i.e., a procedência ou não da pretensão processual), porque lhe faltam elementos para que o juiz possa emitir um juízo conclusivo sobre as relações jurídicas originadas na parcela da fattispecie ali analisada. Trata-se de sentença incompleta, que não prescinde de processos complementares para que seja levada a termo a entrega da tutela jurisdicional. Como é bem observado por TEORI ZAVASCKI, "o que interessa ter presente é que se trata de uma sentença que faz juízo de certeza sobre parte apenas, e não sobre o todo, das relações jurídicas controvertidas, e que tal cognição parcial decorre, justamente, da opção, de natureza político legislativa, de formatar um procedimento especial com atividade cognitiva partilhada" ${ }^{398}$.

A técnica de separar a atividade cognitiva necessária à decisão de uma única causa não é algo de novo na história do direito processo. Ao estudar as relações entre a lide e o processo, e particularmente a diferença de extensão do último frente à primeira, FRANCESCO CARNELUTTI aludiu ao chamado "processo parcial", entendido como aquele que surge nas situações em que há uma pluralidade de processos que contêm uma mesma lide, e que culmina - portanto - com uma sentença também parcial.

\footnotetext{
${ }^{398}$ ZAVASCKI, Teori. Processo coletivo: tutela de direitos coletivos e tutela coletiva de direitos, cit., p. 157.
} 
O aspecto peculiar da sentença parcial - que irá gerar todas as dificuldades para seu enquadramento no regime da coisa julgada - está em que a sua estrutura difere daquela que consta do artigo 458 do Código de Processo Civil. O processo e a sentença parciais se definem, na feliz expressão de ALFREDo BUZAID, como o fenômeno "da unidade da lide discutida e julgada sucessivamente numa pluralidade de relações jurídicas processuais"399. Por isso, por sentença parcial deve se entender aquela sentença de mérito que se limita a analisar determinados aspectos da pretensão, sem exauri-la. Seu conteúdo fica aquém daquele conteúdo mínimo estrutural da pretensão processual. É uma sentença cindida em seus elementos essenciais, e dessa forma ela representa para o processo civil da era moderna - destinado à tutela dos direitos e não à resolução de questões, segundo o postulado da dualidade do ordenamento - aquilo que a fissão do átomo representou para a física. Trata-se de decisão incompleta, que contém em si menos do que aquilo que deveria ser o seu conteúdo mínimo.

Entretanto, há um ponto de especial importância que deve aqui ser considerado. Mesmo nos casos em que excepcionalmente se admite que a sentença contenha menos elementos do que aqueles que formariam a estrutura mínima necessária do processo, por exigências de utilidade prática a tutela jurisdicional continua a exigir esse núcleo, de maneira que as sentenças parciais sempre necessitam de integração por uma posterior sentença que lhes venham a complementar em seus elementos faltantes. E a coisa julgada sobre tais sentenças, dessa maneira, adquire uma nova função de articulação entre as decisões complementares, estranha à coisa julgada tradicional cuja finalidade é apenas a de assegurar o gozo de um bem da vida já reconhecido de forma definitiva.

A sentença genérica coletiva é inequivocamente uma sentença parcial, no sentido que CARNELUTTI reserva a essa expressão. E a nota distintiva que a inclui nessa categoria é o fato de que seu objeto não pode ser bem autônomo de tutela jurídica. Ela é admitida de forma excepcional no sistema, como um instrumento para racionalização do processo, que não teria como abarcar em um único procedimento as inúmeras questões de ordem geral e individual que emergem da lesão de massa ${ }^{400}$. Como observou CAMILO ZuFELATO, “a ação

\footnotetext{
${ }^{399}$ BUZAID, Alfredo. Da liqüidação por artigos em ação de ressarcimento de perdas e danos. Revista de Processo, São Paulo, n. 43, p. 9-13, jul./set. 1986.

${ }^{400}$ A divisão da atividade cognitiva em processos distintos e sucessivos é uma das técnicas de que se vale o sistema processual coletivo para reduzir a complexidade das questões de massa. A doutrina norteamericana estuda as abordagens ao contencioso de complexidade (complex litigation) a partir de diversas maneiras de administração da forma de resolução de questões (narrowing of issues), por vezes reunindo-as em um único processo (consolidated trials), por vezes distribuindo-as por julgamentos sucessivos e parciais (separated trials). É interessante a observação que FRANCESCO MENESTRINA faz a respeito dos casos
} 
coletiva em defesa de direitos individuais homogêneos não guarda um objetivo final em si, ao contrário das ações em defesa dos interesses difusos e coletivos. Será sempre necessária uma 'continuidade', uma segunda etapa do processo coletivo constituída pela liqüidação e execução individuais." ${ }^{401}$. Dessa forma, a sentença é caracterizada por "um grau de abstração ímpar" ${ }^{\circ 02}$, que não atinge a certeza necessária quanto à aplicação da vontade da lei ao caso concreto.

Essa limitação de escopo da ação civil coletivo repercute de maneira incisiva sobre a estrutura da sua sentença de mérito. Na sentença genérica coletiva, o juiz parte da identificação da pretensão deduzida em juízo, tipicamente um cúmulo de pretensões ressarcitórias comum a uma massa de indivíduos ainda não determinados, e a descreve no relatório. Já na fundamentação, a primeira classe de questões a serem resolvidas consiste no exame da regularidade formal do processo, isto é, a aferição da presença dos pressupostos processuais. A seguir, se procede ao juízo de admissibilidade do exame de mérito, pelo examine das condições da ação genéricas e específicas do procedimento especial. Para que se admita a tutela coletiva, ela deve ter contornos específicos: o autor deve alegar uma lesão de massa, causada pelo réu, da qual decorre uma pluralidade de direitos individuais. E mais, ainda: ela deve ter um núcleo de questões comuns suficientes a qualificarem esses direitos como homogêneos, sendo que a homogeneidade pressupõe a predominância das questões comuns e a superioridade da tutela coletiva para a sua resolução ${ }^{403}$. Identificadas essas questões, de fato ou de direito, o juiz passará a resolvê-las gradualmente, apurando os fatos representados na instrução da causa, qualificando-os juridicamente, e finalmente procedendo ao juizo de sua subsunção aos elementos do suporte fático consubstanciado na causa de pedir. Mas ele somente vai até esse ponto.

A partir daí, podem ocorrer duas situações distintas. Caso o juiz reconheça a insubsistência de um dos elementos que devem concorrer para a incidência da lei, ele poderá desde logo julgar integralmente a causa, declarando a improcedência das pretensões homogêneas. Isso ocorre porque a parcela homogênea é prejudicial à integralidade das pretensões, de modo que ao reconhecer a insubsistência, isso já será suficiente para rejeitar

em que se faz conveniente o processo parcial, no sentido de que nada mais se trata do que a aplicação ao processo civil de um velho princípio da tática e da política: "divide e governa" (La pregiudiciale nel processo civile, cit., p. 61).

${ }^{401}$ ZUFELATO, Camilo. Coisa julgada coletiva, cit., p. 398.

${ }^{402}$ ARAÚJO FILHO, Luiz Paulo da Silva. Ações coletivas: a tutela jurisdicional dos direitos individuais homogêneos, cit., p. 134.

${ }^{403}$ GRINOVER, Ada Pellegrini. Da class action for damages à ação de classe brasileira: os requisitos de admissibilidade, cit. 
totalmente a tutela final pretendida em favor dos membros da classe. Esse julgamento, contudo, somente será feito indiscutível para os indivíduos que tenham participado do processo, nela intervindo como litisconsortes, em razão da oponibilidade secundum eventum litis que a lei brasileira atribui a essa modalidade da coisa julgada (art. 103, inc. III e $\S 2^{\circ}$, da Lei $\left.{ }^{\circ} 8.078 / 90\right)$.

Mas ele poderá também considerar que os aspectos homogêneos da causa são compatíveis com as pretensões individuais, caso em que, em lugar de reconhecer a procedência das pretensões, ele fixará a responsabilidade genérica do réu (art. 95, CDC). Ao fazê-lo, ele não chega a concluir o raciocínio sobre a incidência da norma jurídica e, logo, não determina o efeito jurídico a ela ligado. Para isso ele precisaria decidir também questões particulares dos indivíduos que compõem a classe representada pelo autor coletivo. Por isso, a sentença genérica é estruturalmente diferente da sentença comum, pois a rigor ela é desprovida de dispositivo, entendido este como o elemento volitivo pelo qual o juiz formula o juízo de incidência do direito no caso concreto e determina a conseqüência correspondente. Ela não contém um juízo conclusivo sobre a pertinência das pretensões, mas apenas um juízo de probabilidade. E ela não determina a irradiação de eficácia correspondente à tutela pretendida, nada alterando no mundo externo. Trata-se de sentença puramente instrumental, que se limita a preparar o terreno para que os processos complementares, preferencialmente individuais e apenas subsidiariamente coletivos, se desenvolvam de maneira mais célere e uniforme. Por essas razões, sua estrutura interna não ser conduzida ao esquema do artigo 458 do Código de Processo Civil.

Este, pois, os traços gerais da sentença genérica coletiva, que se constitui em sentença parcial sobre o núcleo comum dos direitos individuais homogêneos. Antes de encerramos este item, cabe ainda fazer um esclarecimento quanto à abrangência do conceito de sentença parcial, que nos parece vir sendo indevidamente alargado em tempos recentes.

Isto porque, a partir da edição da Lei $\mathrm{n}^{\circ} 11.232 / 05$, que modificou o conceito da sentença constante do artigo 162 do Código de Processo Civil para defini-la pelo seu conteúdo decisório e não mais pelo efeito de extinguir o processo de conhecimento, parte da doutrina vem defendendo a possibilidade de decisão fracionada das demandas cumuladas em um processo, e chamando a cada uma dessas decisões "sentenças 
parciais" ${ }^{404}$. Na realidade, como nesses casos o que ocorre é o julgamento integral de pretensões processuais autônomas ${ }^{405}$, deduzidas em cúmulo objetivo, seria melhor falar em julgamento parcial do processo, porque a rigor sentença parcial não existe nessas hipóteses. O fenômeno descrito por esses autores diz respeito apenas ao momento em que a sentença é dada, mas, ao contrário daquilo que ocorre nas situações a que nos referimos acima, essa alteração no momento em que profere a sentença não altera de maneira alguma a estrutura da decisão, que é perfeitamente assimilável ao art. 458 do Código de Processo Civil. A existência de mais de uma sentença no mesmo processo, desde que tenham elas objetos autônomos, não parece trazer nada de extraordinário no sistema. Não se enquadra no conceito de sentença parcial, portanto, o fenômeno pelo qual se julga antecipadamente uma ou mais das pretensões cumuladas em um mesmo processo.

\subsubsection{Sentenças parciais no Código de Processo Civil de 1973}

O Código de Processo Civil de 1973 foi bastante restritivo em admitir a possibilidade de sentenças parciais de mérito, mesmo dentro de um mesmo processo, a ponto de se falar em um "dogma da unidade da sentença"406. As origens dessa orientação podem ser creditadas ao princípio da oralidade propugnado por CHIOVENDA, que defendia um único julgamento concentrado de todas as questões do processo como reação às grandes delongas que eram geradas pelo fracionamento da decisão do processo em inúmeras sentenças interlocutórias sujeitas a recurso de apelação, outra característica do processo comum medieval contra a qual se voltou aquele autor.

\footnotetext{
${ }^{404}$ Essa terminologia, que se afasta da conceituação clássica de CARNELUTTI, pode ser encontrada na monografia de SIDNEY PEREIRA DE SOUZA JUNIOR, para quem "tendo esse pronunciamento judicial decidido sobre uma das demandas cumuladas no processo, implicando referida decisão uma das hipóteses previstas nos arts. 267 e 269 do CPC, parece-nos não haver como negar que se trata de uma sentença, a teor do art. $162, \S 1^{\circ}$, do CPC. No entanto, será uma sentença parcial, porque existem outras demandas presentes no processo que ainda aguardam a apreciação" (Sentenças parciais no direito processual civil: conseqüências no âmbito recursal. São Paulo: Método, 2010. p. 55).

${ }^{405}$ Embora nos oponhamos a utilização do termo "sentença parcial" nessa circunstância, é cabível o registro de que o $\$ 301$ da Zivilprozessordnung tedesca utiliza essa nomenclatura (Teilurteil) para se referir ao julgamento antecipado de parte das pretensões cumuladas no mesmo processo. Para se referir à sentença ilíquida, a ZPO utiliza a expressão sentença provisória sobre o fundamento (Swischenurteil, cf. §304).

${ }^{406}$ Como expõe LUIZ GUILHEME MARINONI, o Código de Processo Civil de 1973 "não permitia o fracionamento do julgado do pedido ou de um dos pedidos cumulados. É que a sua originária feição é marcada pelo princípio da unidade e da unicidade do julgamento. Esse princípio quer expressar que o mérito não deve ser resolvido pelo juiz em partes, pois seria mais adequado considerar toda a sua extensão quando do julgamento. Como conseqüência lógica, o processo deveria viabilizar somente uma oportunidade - uma sentença - para sua solução." (Técnica processual e tutela dos direitos, cit., p. 109-110).
} 
E assim, a possibilidade de fracionamento na análise do mérito de uma mesma pretensão foi confinada em poucas hipóteses, cuidadosamente escolhidas de forma que a cisão do mérito se convertesse em fator de celeridade, em lugar de fonte de atrasos na marcha processual. O exemplo onde a sentença parcial encontra mais larga aplicação no direito processual brasileiro é a sentença condenatória ilíquida ou sentença genérica, pela qual se admite a cisão da pretensão condenatória em dois processos diferentes: um primeiro destinado à aferição da responsabilidade, em abstrato, do réu (an debeatur); e outro destinado à apuração do conteúdo da obrigação (quantum debeatur). A norma jurídica de direito material que está à base desses casos é a mesma que se encontra em qualquer demanda de indenização: um primeiro indivíduo age de maneira culposa, provocando prejuízos a um segundo, e torna-se obrigado a reparar o dano, incluindo as perdas e o que se deixou razoavelmente de lucrar em razão do ilícito. Em um processo comum, todos os elementos deveriam ser alegados e provados, e a sentença de procedência condenaria o réu a pagar uma quantia certa ou reconheceria a improcedência da demanda, seja por afastar a responsabilidade, seja por aferir a inexistência de qualquer dano. A sentença genérica separa a questão da responsabilidade da questão da quantificação dos danos, partindo do pressuposto de que se trata de aspectos da causa com razoável grau de autonomia, e que podem assim ser excepcionalmente considerados separadamente. Outros procedimentos especiais, como a ação de prestação de $\operatorname{contas}^{407}$, ou a ação de desapropriação por utilidade pública ${ }^{408}$, permitem igualmente o fracionamento do mérito em sentenças sucessivas e complementares.

\footnotetext{
${ }^{407}$ Trata-se de ação que veicula pretensão condenatória cujo procedimento se desdobra em fases sucessivas, de maneira que uma primeira sentença decide acerca da questão prejudicial relativa ao dever de prestar contas, e a segunda - que somente terá lugar caso seja resolvida de modo favorável a primeira questão determina o valor do saldo devido, conforme artigos 915, §2 , e 918 do Código de Processo Civil.

${ }^{408} \mathrm{~A}$ ação de desapropriação por utilidade pública tem sua cognição disposta, de certo modo, em sentido inverso daquele encontrado na condenação genérica. Com efeito, a primeira fase do processo é dedicada à aferição do quantum debeatur (o "justo preço"); e apenas em um segundo momento é aberto contraditório para a prova da propriedade do bem expropriado, ou seja, para a definição do an debeatur, no qual concorrem aqueles que têm pretensão real sobre o bem (art. 34, Dec.-Lei $n^{\circ} 3.365 / 41$ ). È claro que se não houver controvérsia anterior sobre a propriedade, o processo se resolve com a execução do valor do preço definido, e a segunda fase não chegará sequer a se instalar. As características do direito material permitem que a cisão da atividade cognitiva seja feita de forma racional, sem gerar atrasos para o processo.
} 


\subsubsection{Natureza das sentenças genéricas e das sentenças de liquiidação: divergências da doutrina}

É um tema bastante controvertido, em doutrina, a natureza das sentenças parciais de condenação genérica e de liqüidação. PIERo CALAMANDREI, em um dos primeiros estudos sobre o tema, escreveu que a sentença genérica teria natureza cautelar, porque como o título executivo somente se aperfeiçoaria com a sentença de liqüidação, essa espécie de condenação seria fundada tão somente em um juízo de probabilidade ${ }^{409}$. A doutrina brasileira, contudo, geralmente não questiona a natureza condenatória da sentença genérica, muito embora se reconheça nela a ausência da eficácia executiva própria a essa categoria. Em artigo que dissona levemente desse padrão, HeITOR MENDONÇA SiCA veio a distinguir a sentença genérica da ilíquida, segundo o seu grau de indeterminação: no entendimento do autor, se deixar ela de determinar o objeto da condenação, trata-se de sentença genérica; se deixar de afirmar o valor da obrigação, trata-se de sentença ilíquida. Afirma então que, enquanto esta é de fato condenatória, a primeira seria apenas declaratória $^{410}$.

As divergências se estabelecem com maior intensidade, porém, no estudo da natureza da sentença de liqüidação, em torno de duas correntes. A primeira delas, que se formou na esteira das lições de ENRICO TULLIO LIEBMAN ${ }^{411}$, no particular seguidas por CARlos Alberto CARMonA ${ }^{412}$, CÂNDIDO RANGEl DinAMARCo ${ }^{413}$, i.a., tal sentença teria natureza declaratória, na medida em que se destinaria a tornar certo o valor da obrigação já reconhecida em anterior sentença condenatória. É interessante observar desde logo, no entanto, que o objeto dessa declaração não recai sobre uma relação jurídica de direito

\footnotetext{
${ }^{409}$ CALAMANDREI, Piero. La condanna <<gennerica $>$ ai danni. In: CAPPELLETTI, Mauro (a cura di). Opere giuridiche. Napoli: Morano, 1965. v. 5, p. 503-530. Na doutrina mais recente, ANDREA PROTO PISANI também vê nela um caráter cautelar, em sentido amplo (Lezioni di diritto processuale civile. 5. ed., cit., p. 167).

${ }^{410}$ SICA, Heitor Vitor Mendonça. A nova liqüidação de sentença e suas velhas questões. In: BUENO, Cássio Scarpinella; WAMBIER, Teresa Arruda Alvim (Coords.). Aspectos polêmicos da nova execução. São Paulo: Revista dos Tribunais, 2008. v. 4, p. 210-239.

${ }^{411}$ LIEBMAN, Enrico Tullio. Processo de execução, 3. ed. São Paulo: Saraiva, 1968. p. 1 e ss.

412، 'O processo de liqüidação, não há dúvida, tem caráter declaratório. Julgado procedente o pedido ilíquido, profere o magistrado sentença condenatória genérica, e por isso mesmo, incompleta: declara-se o an debeatur mas não o quantum debeatur, tornando-se necessária nova atividade para declarar, ou melhor, revelar, o valor que basicamente já estaria contido na sentença condenatória” CARMONA, Carlos Alberto. O processo de liqüidação de sentença. Revista de Processo, São Paulo, n. 60, p. 44-55, out./dez. 1990.

${ }^{413}$ DINAMARCO, Cândido Rangel. As três figuras da liqüidação de sentença. In: processo civil moderno. 6. ed. São Paulo: Malheiros Ed., 2010. v. 2, p. 1382-1383. Fundamentos do
} 
material (como exigiria o artigo $4^{\circ}$, do Código de Processo Civil), mas sobre uma questão prejudicial ao seu reconhecimento.

Por outro lado, PONTES DE MIRANDA sustentou que a sentença de liqüidação tem natureza constitutiva-integrativa, pois seria destinada a integrar o título executivo com os elementos que lhe faltem para permitir a execução ${ }^{414}$, em entendimento que é compartilhado por AlCIDES DE MENDONÇA LIMA ${ }^{415}$ e por ARAKEN DE Assis ${ }^{416}$. De igual maneira com o que se afirmou no parágrafo anterior, o critério adotado para se enquadrar as sentenças de liqüidação na categoria das sentenças constitutivas difere também aqui, observe-se, daquele que é tradicionalmente adotado para classificar uma sentença como tal. O que se constitui não é uma relação jurídica de direito material, externa ao processo; o objeto a ser constituído é um pressuposto processual para a atividade executiva, seja a sentença condenatória ou título extrajudicial. Refere-se ele, pois, à constituição de uma situação processual, e não material. Não há propriamente uma tutela constitutiva que seja prestada pela sentença de liqüidação.

Tratando especificamente da sentença genérica coletiva, TEORI ZAVASCKI afirma que ela não irradia a eficácia executiva, por necessitar de complementação ${ }^{417}$; buscando enquadrar a decisão em uma das categorias da tradicional classificação das sentenças, conclui ele também - "por exclusão", em suas palavras - que se trata ela de sentença declaratória $^{418}$. Já em relação à sentença da ação individual complementar, adota ele uma solução de compromisso entre as teorias que definem a sentença de liqüidação como declaratória ou constitutivo-integrativa: elas seriam funcionalmente integrativas, mas preponderantemente declaratórias do ponto de vista substancial ${ }^{419}$. CÂNDIDO RANGEL DinAMARCO, de seu turno, oferece um interessante ângulo de análise: em seu entendimento, a sentença genérica se caracteriza por enunciar tão somente uma

\footnotetext{
414،“(...) a liqüidação faz-se para integrar o título executivo, de modo que não se declara, constitui-se. É constitutiva integrativa a sentença.” (Comentários ao Código de Processo Civil. Rio de Janeiro: Forense, 1997. t. 9, p. 405).

${ }^{415}$ MENDONÇA LIMA, Alcides de. Liqüidação de sentença. In: FRANÇA, Rubens Limongi (Org.). Enciclopédia Saraiva do Direito. São Paulo: Saraiva, 1980.v. 50.

${ }^{416}$ ASSIS, Araken de. Cumprimento de sentença. 3. ed. Rio de Janeiro: Forense, 2010. p. 80.

417،Para alcançar eficácia executiva, ela deverá ser complementada por outra, da qual resultem identificados os elementos faltantes da norma jurídica individualizada" (ZAVASCKI, Teori. Processo coletivo: tutela de direitos coletivos e tutela coletiva de direitos, cit., p. 148).

${ }^{418}$ ZAVASCKI, Teori. Processo coletivo: tutela de direitos coletivos e tutela coletiva de direitos, cit., p. 157.

${ }^{419}$ ZAVASCKI, Teori. Processo coletivo: tutela de direitos coletivos e tutela coletiva de direitos, cit., p. 182.
} 
potencialidade danosa ${ }^{420}$, que somente irá se confirmar se a sentença complementar de liquidação aferir a presença dos elementos constitutivos da obrigação faltantes.

\subsubsection{Crítica ao enquadramento das sentenças parciais nas categorias de classificação da sentença que contém a tutela jurídica integral}

Em que pese a autoridade dos defensores da natureza declaratória da sentença de liqüidação, que parece predominar na doutrina atual, ou daqueles que enxergam nela uma natureza constitutiva, ambas as posições nos parecem inaceitáveis sob os critérios que definem a natureza das duas classes de tutela jurisdicional.

Com efeito, se adotarmos - na esteira da doutrina de Botelho DE MEsquitA, examinada no item 3.2.3.2, no capítulo anterior - como definição de eficácia da sentença as modificações que ela produz nas relações jurídicas externas ao processo; e se identificarmos o efeito declaratório como o vínculo que a sentença impõe à conduta das partes, a partir do reconhecimento de uma determinada relação jurídica, caminharemos para a conclusão de que nem a sentença genérica e nem a sentença de liqüidação irradiam esse tipo de eficácia. E exatamente por isso, o conteúdo de nenhuma delas poderia se constituir em objeto autônomo de tutela jurídica, se não houvesse a excepcional permissão para divisão da causa em dois processos, que se ligam - no entanto - por uma relação de conexão instrumental voltada à tutela de uma única pretensão.

Partindo desses pressupostos, pensamos que não é possível concordar com a tese de que "não há razão alguma para diferenciar a determinação da declaração, eis que aquela não deixa de representar uma forma de accertamento" 421 , pois a determinação de objeto ou quantia contida na sentença de liqüidação não tem a autonomia que a declaração, considerada como bem jurídico, possui. O mesmo pode ser dito a respeito da eficácia constitutiva, que é predisposta sempre à constituição, modificação ou extinção de uma

\footnotetext{
${ }^{420} \mathrm{~A}$ análise de CÂNDIDO RANGEL DINAMARCO nos é de grande interesse, pois apesar de buscar o enquadramento da sentença genérica na categoria tradicional da ação declaratória, postura da qual discordamos pelos motivos expostos no texto, ela vai a fundo na análise da substância do fenômeno: "a nova condenação genérica prevista no art. 95 do Código de Defesa do Consumidor, no entanto, por força de lei e pelo modo como se enquadra no sistema, contém um momento declaratório que não vai mesmo além da afirmação dessa potencialidade danosa. Não reconhece nem declara a existência de concretos e identificados direitos individuais lesados, e muito menos identifica titulares. Deixando esse vazio de declaração, permite toda a amplitude de exame e declaração no processo liquiidatório que cada um dos pretendentes vier a instaurar" (As três figuras da liqüidação de sentença, cit., p. 1.398).

${ }^{421}$ CARMONA, Carlos Alberto. O processo de liqüidação de sentença, cit., p. 44-45.
} 
relação jurídica de direito material, externa ao processo. A diferença está em que embora na sentença de liqüidação se encontre um elemento declaratório parcial, e ela muito embora ela possibilite a constituição de uma nova situação processual pela integração de elementos faltantes do título executivo, são esses efeitos meramente instrumentais e internos ao processo, que não correspondem às tutelas (e eficácias com projeção externa) declaratória ou constitutiva.

$\mathrm{Na}$ realidade, parece-nos que tanto a sentença genérica como a sentença de liqüidação possuem natureza condenatória, embora sejam incompletas e incapazes de irradiar a correspondente eficácia. Falta à sua estrutura o elemento volitivo, que somente é possível após a integração da cognição por sobre todos os elementos que compõem o suporte fático do direito cuja tutela se pede. Em razão dessa incompletude, queira a conclusão do juiz sobre o mérito, queira a irradiação da eficácia jurídica correspondente à pretensão condenatória, somente se aperfeiçoarão pela combinação dos dois fragmentos de sentença em que consistem as decisões parciais. Pois como assinala ANDREA PROTO PISANI, nelas são julgados apenas segmentos de um mesmo direito, e não o direito mesmo $^{422}$. As sentenças parciais estão indissoluvelmente ligadas pela finalidade da tutela jurídica comum a que estão direcionadas, de modo que parece enganoso tentar definir seus conteúdos de forma isolada. À vista da eficácia de direito material pretendida, a sentença genérica e a sentença de liqüidação, complementares que são, devem ser analisadas como um único conjunto ${ }^{423}$.

Dessa forma, não se podem considerar as sentenças de condenação genérica ou de liqüidação como sentenças declaratórias, no sentido de sentenças que irradiem eficácia material para fora do processo, vinculando o comportamento das partes. Elas contêm ambas, é certo, um juízo parcial sobre o mérito da pretensão que se faz valer em juízo, de modo que a condenação genérica gera uma expectativa de condenação (ou potencialidade

\footnotetext{
${ }^{422} \mathrm{E}$ a idéia que o autor claramente expõe no seguinte trecho: "questo fenomeno consente di porre in evidenza come la condanna generica abbia ad oggetto non una situazione giuridica, un diritto in senso stretto $m a$ solo - come si è già detto - un segmento di una situazione giuridica esistente tra le parti: un segmento, un frammento di diritto che solo $1^{\prime}$ 'esplicita disposizione dell'art. $278,1^{\circ}$ comma, consente, eccezionalmente, di divenire oggetto (autonomo) di sentenza allo scopo (lato sensu cautelare) di antecipare la messa a disposizione dell'attore di un titolo per l'iscrizione di ipoteca giudiziale; in base a tale assunto la sentenza in esame può e deve, per definizione, essere posta nel nulla dalla sucessiva sentenza sulla liquidazione, che accerti l'insussiztenza quantitativa del diritto. Un diritto quantitativamente inesistente è infatti un non diritto". (PROTO PISANI, Andrea. Lezioni di diritto processuale civile. 5. ed., cit., p. 166-167, g.n.).

${ }^{423}$ Nesse sentido, LUIZ GUILHERME MARINONI e SĖRGIO ARENHARDT afirmam que "quando se constata que a tutela do direito é apenas uma (a tutela ressarcitória pelo equivalente), torna-se fácil perceber que há apenas uma ação e um processo, ainda que a tutela jurisdicional do direito exija a fase de conhecimento e possa depender das fases de liqüidação e execução" (Execução. 2. ed. São Paulo: Ed. Revista dos Tribunais, 2008. p. 125).
} 
lesiva, como diz DinAMARCo) que está subordinada à apuração do dano na fase de liqüidação. Nesse sentido é que ALFREDO BUZAID, autor daquela que provavelmente é a mais profunda monografia escrita em nosso país sobre a ação declaratória, viria a afirmar que a sentença de liqüidação não pode ser definida a partir de nenhuma das classes tradicionalmente aceitas. Não se trata de sentença declaratória, demonstra BUZAID, porque estas devem ter por objeto necessário uma relação jurídica ${ }^{424}$. E a mesma linha de argumentação afasta a tese de PONTES DE MIRANDA, que via na liqüidação um caráter constitutivo-integrativo: também a constituição que caracteriza essa classe de sentenças deve ter por objeto a modificação de uma relação jurídica ${ }^{425}$. Conclui o autor afirmando que a sentença de liqüidação deve ser classificada em critério próprio, que chama de sentença determinativa.

Na esteira dessas lições de Buzaid, realmente nos parece que nem a sentença genérica e nem a sentença de liqüidação devem ter sua natureza investigada de modo apartado uma da outra, pois elas na realidade constituem partes integrantes de um mesmo ato jurisdicional fragmentado em processos distintos. Mais importante do que buscar a classificação isolada das sentenças parciais sob as categorias tradicionais, portanto, é perceber o nexo indissolúvel que as liga, e que as funcionalizam à tutela de uma mesma pretensão.

Pois a verdade que há nessa matéria, como expõe CÂNDIDO DinAmARco, é que “quando na liqüidação da sentença genérica o juiz fixa o quantum debeatur, outra coisa não está a fazer senão a cumprir depois uma função que não realizara antes, ao condenar. Ou seja, ele realiza a integração do momento declaratório da sentença de condenação, ao acrescentar à declaração da existência do crédito a declaração do valor deste. A determinação do quantum debeatur ficara diferida no tempo e agora sobrevém. Conhece-se agora, por inteiro, a vontade concreta do direito a atuar ${ }^{\prime 426}$.

\footnotetext{
424، $\mathrm{Na}$ verdade, a sentença que determina o quantum da condenação não tem caráter declaratório. A sentença é declaratória quando se limita a declarar a existência ou a inexistência de relação jurídica. Ela é, de sua própria natureza, aquela que não visa a nada mais do que à pura declaração, nem pode procurar outro objetivo além da pura declaração.” (BUZAID, Alfredo. Da liqüidação por artigos em ação de ressarcimento de perdas e danos, cit.).

425، (...) na liqüidação não há constituição, modificação ou extinção de relação jurídica. A relação jurídica continua a mesma, embora incompleta, por lhe faltar a determinação do quantum, sem sofrer integração de qualquer elemento novo. A determinação do quantum não é elemento integrativo da sentença; é elemento revelador que está imanente e ainda não foi determinado" (Op. cit., idem).

${ }^{426}$ DINAMARCO, Cândido Rangel. As três figuras da liqüidação de sentença, cit., p.1382.
} 
Assim, do ponto de vista substancial, da combinação da sentença genérica e da sentença de liqüidação se obtém uma única sentença ${ }^{427}$, cujo conteúdo é tipicamente condenatório. Por isso, a classificação dessas duas sentenças parciais, à luz da tutela por elas prestada, somente pode ser a de sentenças condenatórias, muito embora não sejam elas auto-suficientes e devam, assim, ser combinadas para que a eficácia característica da tutela condenatória possa se desencadear.

\subsection{Teorias sobre a coisa julgada na sentença parcial de mérito}

Tendo em vista o caráter residual das sentenças parciais de mérito em nosso processo civil, é natural que a doutrina não tenha se aprofundado no estudo da coisa julgada parcial, muito embora - como teremos oportunidade de verificar mais adiante, no item 4.3.1 - os problemas relacionados a esse tipo de decisão sejam algumas vezes enfrentados pela figura do "princípio da fidelidade da liqüidação ao título", sugerindo um tratamento específico, ainda que não sistematizado, para as peculiaridades desse tipo de situação.

O maior desenvolvimento na teorização da coisa julgada sobre a sentença parcial veio da doutrina italiana. Para isso, pesa a circunstância de que a lei processual daquele país permite a fragmentação da cognição da causa em hipóteses muito mais amplas do que em outros ordenamentos: a par da já mencionada condenação genérica, é admitida de modo amplo a possibilidade do julgamento antecipado de questão prejudicial que possa definir o litígio, e a eventual provimento do recurso de cassação de sentença dá origem a um novo processo, em que se manifesta o vínculo do "princípio de direito" firmado pela Corte. Em todas essas hipóteses, existe em comum o julgamento definitivo de mérito de uma parte

\footnotetext{
${ }^{427}$ É o que sustenta ATHOS GUSMÃO CARNEIRO, à luz da reforma introduzida pela Lei n. 11.232/2005, que eliminou a citação para o processo de liqüidação, convertendo-o em fase que se inicia após o trânsito em julgado da sentença genérica: "A ação é, pois, uma e única, decorrente de pretensões já predeterminadas e destarte abrangentes de todas as sucessivas fases em que se desenrola o processo. (...) Cremos, destarte, superados os antigos questionamentos sobre a natureza jurídica da antiga 'ação' de liqüidação de sentença: se declaratória, constitutiva ou condenatória (...). Ao fixar o quantum debeatur, a decisão integra-se na sentença que afirmara o an debeatur, e destarte a sua natureza será a mesma da sentença integrada" (Cumprimento da sentença civil e procedimentos executivos. 2. ed. Rio de Janeiro: Forense, 2011. p. 23). O que se pode acrescentar a esse posicionamento, essencialmente correto, do antigo Ministro do Superior Tribunal de Justiça é que, independente da mudança procedimental introduzida pela reforma de 2005, sob o regime anterior já se tratava de uma única pretensão processual dividida em processos distintos, razão pela qual essas mesmas conclusões já seriam perfeitamente válidas. E por essa mesma razão, ao processo de cumprimento da sentença coletiva, que exige uma citação para a fase de habilitação e cumprimento, também se aplica o mesmo raciocínio.
} 
das questões que interessam à tutela jurídica pretendida, restando ainda uma margem aberta à cognição das demais questões necessárias para a decisão da causa, o que pode eventualmente ser feito em um segundo processo. Dessa forma, em nossa análise adotaremos como parâmetro diferentes enquadramentos que a doutrina peninsular deu à questão, que lhes é mais familiar pelas características de sua lei processual.

\subsubsection{Dificuldades para aplicação da disciplina da coisa julgada à sentença parcial: a incerteza (o problema da "liqüidação zero") e a ausência de elemento volitivo}

O mais importante problema com o qual a teoria da coisa julgada deve lidar, ao tratar com as sentenças parciais definitivas de mérito, é o da incerteza residual que essas sentenças, em maior ou menor grau ${ }^{428}$, sempre carregam consigo. Esse problema é habitualmente referido como a possibilidade de "liqüidação zero" 429 . A doutrina sempre teve resistências em admitir que um processo, cuja sentença de procedência transitou em julgado, pudesse se revelar desprovido de efeitos práticos por ocasião de sua liqüidação ${ }^{430}$, embora durante muito tempo essa questão tivesse mais interesse acadêmico do que prático. A doutrina brasileira mais recente chega a distinguir a sentença simplesmente ilíquida da genérica $^{431}$, segundo deixe ela de especificar o valor ou o objeto sobre o qual recaia a

\footnotetext{
${ }^{428}$ CARNELUTTI afirma que sem a certeza não chega a haver verdadeira condenação, mas apenas uma probabilidade de condenação a que a lei pode eventualmente até atribuir eficácia executiva. Ainda assim, "ognuno vede que in questo modo na condanna perde il suo vero carattere, che consiste nell' accertamento, prima di tutto, dell'obbligo; la condanna diferisce dal mero accertamento non perché non sia un accertamento, ma perchè il contenuto dell'accertamento si estende, come fu ormai detto più volte, dall'obbligo alla responsabilità; ora quando è riservato l'esame di questioni, dalla cui soluzione può risultare l'inesistenza dell'obbligo, è chiaro che un accertamento di questo non esiste; non si può dare certezza ove rimane qualcosa di incerto intorno al rapporto da accertare" (Diritto e processo, cit., p. 308). O grau de incerteza das sentenças genéricas, contudo, é variável. Pode se dizer que as sentenças que deixam de especificar o objeto da condenação tenham um maior grau de indeterminação, e de maior incerteza do que aquelas que apenas deixam de especificar apenas o valor da obrigação. Do ponto de vista estrutural, contudo, são sentenças similares; são ambas fundadas em um juízo de verossimilhança que pode não se confirmar no momento da liqüidação.

${ }^{429}$ Como sublinha ARAKEN DE ASSIS, “nem sempre a liqüidação se mostrará frutífera. Às vezes, nada apurará a favor do vitorioso aparente. $\mathrm{O}$ fenômeno se prende, fundamentalmente, às deficiências na produção e na avaliação da prova dos ilícitos, a cargo do autor, iludindo o órgão judiciário quanto à real existência do dano. Configura-se, assim, a chamada condenação aparente" (Cumprimento de sentença, cit., p. 99).

${ }^{430}$ Para um relato da controvérsia que existiu na jurisprudência do Supremo Tribunal Federal a respeito da admissibilidade da liqüidação zero, ainda sob a vigência do art. 915 do Código de Processo Civil de 1939, que admitia nova liqüidação caso a primeira restasse infrutífera (em autêntico caso de coisa julgada secundum eventum litis), EGAS MONIZ DE ARAGÂO, Notas sobre liqüidação de sentença. Revista de Processo, São Paulo, n. 44, p. 21-30, out./dez. 1986, especialmente p. 27-28. Na doutrina italiana: ROGNONI, Virginio. Carattere della pronuncia di condanna generica. Rivista di Diritto Processuale, Padova, v. 7, p. 105-116, 1952.

${ }^{431}$ SICA, Heitor Vitor Mendonça. A nova liqüidação de sentença e suas velhas questões, cit., passim.
} 
condenação, o que indica que o grau de indeterminação permitido às sentenças parciais em nosso sistema é tão residual, que o problema raramente se apresentava. Mas essas elaborações mais recentes indicam também que com o alargamento que a prática e a jurisprudência vêm impondo à admissibilidade do pedido genérico ${ }^{432}$, bem como com o surgimento de instrumentos como o da ação civil coletiva do artigo 91 e seguintes da Lei $\mathrm{n}^{\mathrm{o}} 8.078 / 90$, o tema tem passado a despertar maior interesse entre nós.

A admissão da possibilidade da "liqüidação zero" coloca em questão a estabilidade da coisa julgada sobre a sentença parcial que reconheceu a responsabilidade. Para ilustrar essa afirmação, imaginemos uma condenação genérica fundada no artigo 286, segunda parte, do Código de Processo Civil. Um ulterior processo de liqüidação, por si só, já é prova da submissão da condenação a discussão posterior, e a eventual demonstração pelo réu de que não houve realmente dano a ser reparado leva essa discussão ao extremo de esvaziar de qualquer eficácia o primeiro julgamento, de onde se poderia eventualmente deduzir a modificação do juízo condenatório caso se considerasse desde logo presente a eficácia condenatória na sentença genérica. Surge assim o problema de saber se o juiz do segundo processo, em que se apura a inexistência de danos, está vinculado a determinar alguma condenação em razão do que ficou decidido no processo anterior, assegurando seu resultado prático, ou se tem ele liberdade de julgar improcedente a liqüidação, na medida em que a questão sobre a existência de danos não havia, realmente, sido decidida em profundidade pela sentença genérica. De qualquer forma, se verifica que a estabilidade da sentença parcial acaba por ser relativa e mais sujeita a contestações do que se passa com o processo ordinário. Além disso, essa incerteza residual que sempre se faz presente nas sentenças genéricas, em razão das questões deixadas em aberto para serem resolvidas em futuros processos complementares, evidencia que nelas não se chega a decidir a lide de maneira definitiva, o que gera perplexidades, porque justamente o elemento decisório (ou

\footnotetext{
${ }^{432}$ De modo crítico, ARAKEN DE ASSIS registra que "aponta a experiência o progressivo e intencional alargamento da bitola legislativa, tolerando-se o pedido genérico, por igual, quando o autor estima trabalhoso, ou taticamente inconveniente, quantificar desde logo a sua petição". E precisamente em razão desse alargamento das estreitas hipóteses de admissibilidade do pedido genérico, também para o autor gaúcho, a questão da "liqüidação zero" adquire uma relevância até então inexistente: "a indiscriminada formulação de pedidos genéricos, à margem dos permissivos do art. 286, I a III, implica o lastimável descaso probatório do demandante, na maioria dos casos, quanto à configuração do dano. Concebe-se que, ao fim e ao cabo, a condenação seja mais aparente do que real, nada apurando a condenação" (ASSIS, Araken de. Comentários ao Código de Processo Civil. Rio de Janeiro: Forense, 2000. v. 6, p. 274 e 277). No mesmo sentido e do mesmo autor, já sob o regime introduzido pela Lei n. 11.232/2005, Cumprimento de sentença, cit., p. 76.
} 
dispositivo) é a única parte da sentença que normalmente se considera protegido pela coisa julgada $^{433}$.

Esse não é o único ponto em que a aplicação da disciplina da coisa julgada sobre as questões decididas no processo parcial gera incongruências. Tendo em vista que os elementos do suporte fático da pretensão deduzida em juízo podem, simultaneamente, integrar o suporte fático de outras pretensões que não foram objeto de demanda das partes, a eficácia panprocessual do vínculo gerado pela coisa julgada, abrangendo todos e quaisquer processos em que esses pontos de fato ou direito sejam discutidos, é capaz de gerar resultados inesperados e para os quais as partes não tiveram condições de se preparar ao exporem suas alegações e defesas no processo parcial. Trata-se de problema de idêntica natureza daquele relacionado à extensão da coisa julgada aos fatos e fundamentos jurídicos contidos na motivação da sentença.

Dessa forma, a aplicação do regramento geral da coisa julgada sobre a sentença parcial, sem maiores considerações para a peculiaridade dessa espécie de decisão, cria inconvenientes que vão de encontro aos objetivos que essa mesma disciplina quer evitar. Se a coisa julgada quer precisamente assegurar a estabilidade da decisão, esse objetivo é de difícil compatibilização com o fenômeno da "liqüidação zero", que anula o resultado prático da primeira sentença. De outro lado, se o regime dos limites objetivos pretende justamente circunscrever a coisa julgada aos limites da lide, a fim de evitar conseqüências inesperadas do julgado, torna-se problemático admitir a formação da coisa julgada sobre decisões que não chegam a exaurir a sua solução. Em razão desses paradoxos, a coisa julgada parcial mereceu atenção específica da doutrina processual italiana, país em que o legislador recorreu mais habitualmente à técnica da fragmentação da análise do mérito ${ }^{434}, \mathrm{e}$ ela desenvolveu diferentes explicações para o instituto: desde a negação peremptória da formação da coisa julgada, até a aceitação irrestrita de sua formação no extremo oposto. No meio do caminho, há quem defenda que se trata de um instituto autônomo, sui generis.

\footnotetext{
${ }^{433}$ Para CÂNDIDO RANGEL DINAMARCO, seria "um absurdo lógico a afirmação de uma suposta estabilização dos efeitos externos de uma sentença que não os tem" (Instituições de direito processual civil. Instituições de direito processual civil, cit., v. 1, p. 311). E, no entanto, é precisamente esta a situação das sentenças genéricas, desprovidas que são de efeitos que se irradiem sobre o plano das relações materiais externas ao processo.

${ }^{434}$ Os estudos a respeito se desenvolveram, na Itália, a partir das regras do art. 393 do c.p.c., que prevê expressamente eficácia externa às questões de direito resolvidas ela Corte de cassação e do art. 187 do c.p.c., pelo qual o juiz instrutor pode remeter o processo antecipadamente ao colegiado competente para julgar a causa em primeiro grau, para que este órgão aprecie uma questão de mérito que possa definir desde logo o processo; nos dois casos, assim, têm-se sentenças parciais definitivas sobre questões de mérito.
} 


\subsubsection{Teoria da preclusão extraprocessual}

A primeira linha de explicação para os vínculos gerados pelas sentenças parciais de mérito não se deteve na análise da natureza desse fenômeno, mas antes, adotou um método de exclusão. Ao se verificar que as sentenças parciais não definem o mérito da lide em caráter definitivo (em razão da inerente incerteza residual por elas permitida, cf. item 4.2.1 supra), da sua incapacidade de atribuir ou negar um bem da vida, e em suma, de concluir pela incidência ou não do direito ao caso concreto, as primeiras análises se preocuparam mais em afirmar que a sentença parcial não faz coisa julgada do que em examinar de maneira mais detida quais são as suas eficácias (no plano material ou processual) e em como elas se manifestam.

Nessa linha, em um ensaio tardio de sua produção (Cosa giudicata e preclusione, de 1933$)^{435}$, Chiovenda viria a definir o fenômeno como uma espécie de preclusão. O conceito de preclusão, que teve uma importância central em sua obra, tinha a significação original da perda, extinção ou consumação de uma faculdade processual, explicada pela necessidade de que o processo se desenvolvesse de maneira rápida e ordenada ${ }^{436}$. Nesta acepção o conceito é bem aceito pela doutrina, bem assim como sua divisão nas três categorias de preclusão temporal, preclusão lógica e preclusão consumativa, que o mesmo autor propôs. Posteriormente, CHIOVENDA viria a agregar ao conceito também as preclusões para o juiz, que consistiriam na firmeza das decisões interlocutórias tomadas no curso do processo.

$\mathrm{Na}$ oportunidade do ensaio aqui discutido, o autor viria a introduzir uma quinta modalidade de preclusão: a preclusão de questões, com projeções interna e externa ao processo. ChIOvEnda considerou em seu argumento as decisões interlocutórias tomadas no curso do processo, e também diversas hipóteses em que o direito processual italiano da época permitia que o julgamento de uma causa fosse fracionado em mais de uma sentença de mérito parcial, como a sentença de condenação com reserva de exceções, o juízo de reenvio que se seguia ao julgamento de ponto de direito pela Corte de Cassação, entre outros. E passou a examinar qual a eficácia externa que as sentenças alcançadas nesses processos irradiariam sobre outros processos que lhes seguissem.

\footnotetext{
${ }^{435}$ Publicado posteriormente em seus SAGGI di diritto processuale civile, cit., v.3, p. 231 e ss.

${ }^{436}$ SAGGI di diritto processuale civile, cit., v.3, p. 232.
} 
Afirmava ele que essas questões passariam a ser eliminadas do objeto de conhecimento do juiz, na medida em que fossem decididas, e a constituir elementos para a decisão final do processo. Por um lado, poderiam elas constituir material lógico ou fragmentos da futura decisão de acolhimento ou rejeição da demanda, conforme fossem combinadas as distintas e sucessivas sentenças; mas por outro, elas poderiam igualmente perder qualquer importância e se revelar como matéria inútil se posteriormente fosse declarada a insubsistência de alguma das condições para acolhimento do pedido, ou acaso fosse aceita alguma das exceções do réu. Por isso, todas essas decisões preclusas, embora dizendo respeito ao mérito, não seriam mais que material coletado ao longo do caminho que só eventualmente se mostraria útil para o processo em curso. Não reuniriam elas as condições, portanto, para alcançar uma estabilidade mais perene, como aquela que o instituto da coisa julgada visa a assegurar. CHIOvENDA foi assim expresso em afastar esse tipo de preclusão do conceito de coisa julgada; "questa preclusione" - escreveu - "non abbia nulla che fare colla cosa giudicata" ${ }^{\star 437}$, pois enquanto esta última tem por finalidade garantir a intangibilidade do resultado do processo, a preclusão de questões, inclusive quando elas digam respeito ao mérito, quer apenas eliminar obstáculos, por razões de utilidade prática. A coisa julgada, ademais, consistiria sempre em um bem da vida reconhecido ou negado ao autor, outro elemento-chave de sua teoria da coisa julgada, que decorre da concepção que o mesmo autor desenvolve da jurisdição. E de fato, toda a seção final do ensaio se dedica a expor a sua concepção da jurisdição moderna, em que enxergava uma inspiração romanística oposta ao germanismo do período medieval, para firmar que apenas essa classe de decisões poderia se tornar objeto da res judicata.

Infelizmente, o ponto que se deixa de aprofundar, em Cosa giudicata e preclusione, está em quais seriam os elementos que conduziriam a estabilidade de tais decisões parciais de mérito com eficácia extraprocessual ao conceito de preclusão, ao qual elas não parecem se adaptar com facilidade. Tudo leva a crer que, na realidade, nesse texto o autor tenha se servido do instituto da preclusão como um conceito residual que pudesse comportar, sem maiores rigores, quaisquer fenômenos de estabilidade processual que não pudessem se enquadrar em sua concepção, mais rígida, da coisa julgada. Essa opção metodológica, entretanto, não é desprovida de problemas. De início, ela gera um grave dano para o conceito de preclusão desenvolvido anteriormente pelo próprio CHIOVENDA, pois para que ela se adaptasse à estabilidade das decisões tomadas pelo juiz no mesmo ou em outros

${ }^{437}$ SAGGI di diritto processuale civile, cit., v.3, p. 237. 
processos, essa categoria processual teve de ter suas definições alargadas e até mesmo desnaturadas, ao ponto de - consoante a crítica que já havia sido feita por PAOLO D'ONOFRIO $^{438}$, e que ele responde de modo pouco convincente - se tornar tão ampla a ponto de não mais definir coisa alguma.

Os vínculos que a sentença dada em um processo parcial irradia sobre processos futuros, com efeito, não consistem em "perdas de faculdades processuais", nem mesmo por aproximação. Isto porque a preclusão é fenômeno endoprocessual ${ }^{439}$, voltado à ordenação e racionalização do procedimento pela eliminação de questões e fases já ultrapassadas, que não se confunde nem com a coisa julgada formal (que se distingue por sua característica eficácia sanatória de nulidades) e nem com a coisa julgada material (que se distingue pela eficácia panprocessual, destinada a operar em processos futuros). Assim, a tentativa de enquadrar os vínculos externos gerados pela sentença parcial de mérito no conceito de preclusão se mostrou insatisfatória, na medida em que exigiu a deformação dessa categoria processual $^{440}$.

Por fim, neste tópico, como estamos a falar de preclusão, há que se fazer uma breve menção à figura da preclusão pro iudicato, concebida por ENRICO REDENTI para justificar a estabilidade de resultados do processo em que não tenha havido cognição aprofundada sobre o mérito, como o caso da execução de título extrajudicial que não tenha sido impugnada. A preclusão pro iudicato não se dirige às sentenças parciais, mas busca conferir projeção extraprocessual às modalidades clássicas da preclusão, que consistem em perdas de faculdades processuais ${ }^{441}$. Ela se aproxima da coisa julgada do ponto de vista

\footnotetext{
${ }^{438}$ D'ONOFRIO, Paolo. Sul concetto di preclusione. In: Studi di diritto processuale in onore di Giuseppe Chiovenda nel venticinquesimo anno del suo insegnamento. Padova: CEDAM, 1927. p. 427-437. p. 427-437.

${ }^{439}$ DANIEL AMORIM ASSUMPÇÃO NEVES parte desse mesmo pressuposto para recusar o conceito de preclusão pro judicato: "tal fato se verifica em razão da preclusão também ser, a exemplo da coisa julgada formal, fenômeno endoprocessual, gerando seus efeitos tão-somente nos processos em que se derem" (Preclusões para o juiz: preclusão pro judicato e preclusão judicial no processo civil. cit., p. 53). No mesmo sentido, HUMBERTO THEODORO JUNIOR distingue os conceitos de preclusão e coisa julgada segundo o critério do âmbito de eficácia de cada qual, afirmando que "enquanto a coisa julgada em seus moldes materiais se projeta para o exterior do processo, assumindo a força de lei entre as partes, com eficácia para o processo encerrado e para qualquer outro em que entre as mesmas partes se venha a debater a mesma lide (CPC, art. 468), a preclusão se exaure dentro do processo e nunca irradia seus efeitos para fora dele" (THEODORO JÚNIOR, Humberto. A preclusão no processo civil. Revista dos Tribunais, São Paulo, n. 784, fev. 2001).

${ }^{440}$ Comentando esse mesmo artigo de CHIOVENDA no contexto de um diferente objeto de estudo, e convergindo com a opinião aqui manifestada, HEITOR VITOR MENDONÇA SICA afirma "o autor não ter enfrentado adequadamente a imutabilidade de determinadas questões incidentais para fora do processo" (Preclusão processual civil. 2. ed. São Paulo: Atlas, 2008. p. 83).

${ }^{441}$ Nessas hipóteses, afirmou REDENTI, “(...) si può procedere ad esecuzione forzata processuale anche in virtù di titolo esecutivi stragiudiziali, senza che si accerti giudizialmenet si el crédito in realtà existe. Soltanto se i soggetti passivi insorgano, opponendosi ala esecuzione prima che sai compiuta, potrà sorgerne
} 
prático, mas dela se distingue por não conter decisão judicial sobre as questões relativas ao mérito da causa ${ }^{442}$. Para os casos em que existe a declaração judicial, ainda que ela se circunscreva apenas a um ponto de fato ou direito da causa, esse autor entendia que se formava autêntica coisa julgada. É essa sua posição que examinaremos a seguir.

\subsubsection{Teoria da coisa julgada sobre questões}

Durante muito tempo, preponderou na doutrina o entendimento CHIOVENDA, no sentido de que somente seriam passíveis de serem acobertadas pela coisa julgada as sentenças dos juízes que negassem ou reconhecessem um "bem da vida" a uma das partes. Por essa influência, a interpretação que se fazia do artigo 2.909 do Código Civil italiano, no sentido de que a coisa julgada era uma propriedade do accertamento contido na sentença, tornava o instituto dirigido apenas as sentenças que definiam o mérito do direito controvertido com o atributo da certeza, julgando - portanto - integralmente a pretensão.

Foi apenas na metade do século passado, passados já quase vinte anos do ensaio chiovendiano que comentamos no item anterior, que veio a luz um trabalho doutrinário que sustentou a idéia de que não existe qualquer obstáculo, de ordem prática ou conceitual, que impeça a aplicação dos princípios e regras da coisa julgada material para as sentenças que decidem apenas questões de fato ou direito; assim, a tradicional exigência de que a coisa julgada se forme sobre uma sentença que contenha a atribuição definitiva de um bem da vida incorreria em petição de princípio. Essa teoria foi formulada pela primeira vez por ENRICO REDENTI no artigo Il giudicato sul punto di diritto, de 1949, que VITTORIO DENTI responsável por posteriores desenvolvimentos na teoria a respeito do assunto, que

um giudizio di gognizione e sbocare in um accertamento. Ma se opposizione non vi sia e l'esecuzione giunga indisturbata fino al suo termine, questo rappresenterà igualmente qualche cosa di irrevocabile e di irreparabile. Da questo momento nessuno potrà più insorgere contro il fato compiuto per distruggerlo o infirmarlo. E in questi limiti si avrà um risultato prático, símile a quello che si avrebe, se fosse copperto dal giudicato. Si puòparlare pertanto in questi casi di preclusione pro iudicato". (Diritto processuale civile. Milano: Giuffrè, 1957. v. 3, p. 71, g.n.)

${ }^{442}$ Deve-se observar que a doutrina brasileira, ocasionalmente, se utiliza da expressão preclusão pro iudicato para referir à preclusão sobre questões no curso do processo, emprestando-lhe um significado diverso daquele que o termo assume na obra de REDENTI. Essa confusão foi objeto da crítica de DANIEL AMORIM ASSUMPÇÃO NEVES, que na busca de maior apuro conceitual, propõe a utilização da expressão "preclusões para o juiz" para esse fenômeno (Preclusões para o juiz: preclusão pro judicato e preclusão judicial no processo civil. cit., p. 25). 
examinaremos na seqüência de nosso trabalho - viria a chamar de "iluminador"443, justamente por romper com uma concepção que já se impunha como dogma, abrindo as portas para que se passasse a estudar outras formas de expressão da coisa julgada que não aquela que cobria as sentenças definitivas.

A partir desse artigo, porém, em que analisa a situação particular da decisão sobre o ponto de direito resolvido pela Corte de Cassação, REDENTI passa a defender a formação de coisa julgada sobre as questões de direito ou fato ${ }^{444}$ que se resolvam no curso do processo. O raciocínio defendido por esse autor é o de que, diante de uma sentença parcial de mérito, muito embora o juiz não tenha decidido de forma definitiva a pretensão, as questões prejudiciais de fato ou de direito resolvidas desde logo se tornam imutáveis. Portanto, a sentença já irradiaria uma eficácia externa, no plano do direito material, que vincula o comportamento das partes ${ }^{445}$.

É importante observar que a teoria da coisa julgada sobre questões, nessa formulação inicial, é estreitamente vinculada a uma concepção substancial da coisa julgada. Como fonte da criação do direito no caso concreto (e não de mera declaração do direito que incidiu), a eficácia da sentença que julga a pretensão deve necessariamente estar apoiada na resolução de questões prejudiciais que sejam igualmente eficazes no plano externo. É uma visão muito próxima da que RonALDO CunHA CAMPOS expõe a fim de defender a extensão a coisa julgada às questões prejudiciais, no direito brasileiro ${ }^{446}$. Sob esse ângulo, as questões prejudiciais não são apenas elementos lógicos compreendidos no iter de formação da decisão sobre o direito aplicável no caso concreto, constituindo-se em pressupostos da formação do direito em si mesmo. Nesse contexto, a exigência de coerência da decisão final do processo com os seus antecedentes lógicos, no plano externo, é tão premente como em concepções mais antigas, que associavam a coisa julgada a uma

\footnotetext{
${ }^{443}$ DENTI, Vittorio. Sentenze non definitive su questione preliminare di merito e cosa giudicata. Rivista di Diritto Processuale, Padova, p. 392, 1969.

${ }^{444}$ Muito embora REDENTI desenvolva suas idéias tendo em consideração a definição do principio di diritto (questão de direito) pela Corte de Cassação, e a despeito de seu artigo se referir no título a julgado sobre o "ponto de direito", ao fim do texto é afirmado que as mesmas considerações aplicam-se irrestritamente também a sentenças que resolvam questões de fato. O que importa é que se tratem de sentenças parciais, que não definam o mérito de uma pretensão específica, ou - para nos valermos da linguagem de CHIOVENDA - que não atribuam um bem da vida às partes.

${ }^{445}$ Para REDENTI, nessa hipótese, as partes:“ (...) sano e devono sapere che se i fatti siano per resultare in un determinado modo o in un determinado senso, la norma applicabile è quella dettata dal giudice $e$ non può essere altra; e se non vi si uniformino il loro comportamento sarà eo ipso antigiuridico e le esporrà ai relativi provvedimenti di sanzione o di tutela giurisdizionale a favore altrui. $\mathrm{E}$ allora, se così è, non può esservi che non veda che la enunciazione, uscendo, perscosì dire, dal processo, è già andata ad incidere nel mondo dei fenomeni di diritto sostanziale" (Il giudicato sul punto di diritto. Rivista Trimestrale di diritto e procedura civile, anno 3, p. 263, 1949, grifos nosssos).

${ }^{446}$ CAMPOS, Ronaldo Cunha. Limites objetivos da coisa julgada, cit., passim.
} 
ficção de verdade. Como já visto no capítulo anterior, essa concepção de coisa julgada não se adapta às feições da jurisdição no moderno Estado de direito, que imprimem ao instituto um caráter processual, cujas suas fontes de legitimação residem na autoridade estatal e de funções eminentemente práticas, voltadas à solução de um conflito determinado.

Mas a construção da coisa julgada sobre questões não está, necessariamente, associada à concepção substancial da coisa julgada. Mais recentemente, a formação de coisa julgada sobre questões foi defendida por dois trabalhos que alcançaram grande destaque, cada um deles partindo de um distinto ponto de vista, sem que nenhum deles pressuponha a necessariamente a teoria material. Em 1972, MiCHELLE TARUFFO publicou o artigo "Collateral Estoppel" e giudicato sulle questioni, em que, a partir do estudo da issue preclusion do direito norte-americano, defendeu a possibilidade de formação de uma coisa julgada autônoma sobre questões discutidas na causa ${ }^{447}$, desde que fossem observados os requisitos que são exigidos naquele país para a excepcional extensão da coisa julgada a questões de fato ou direito resolvidas incidentemente: a efetiva decisão sobre o ponto, o contraditório prévio, o efetivo direito de defesa, elementos esses que são aferidos de forma casuística nos processos futuros e que tornam esse sistema particularmente permeado de incertezas ${ }^{448}$.

A proposta de Michelle TARUfFo foi severamente criticada por GIROLAMO MONTELEONE, para quem a tese, não bastasse partir de uma interpretação muito discutível da lei italiana, representa no fundo a abolição de qualquer limite para a coisa julgada, seja no plano objetivo, seja no plano subjetivo ${ }^{449}$.

\footnotetext{
${ }^{447}$ É verdade que, para defender a aplicabilidade do collateral estoppel (atualmente denominado de issue preclusion) no direito italiano, MICHELLE TARUFFO partiu da teorização que VITTORIO DENTI elaborou sobre a "coisa julgada sobre a fattipecie", que examinaremos mais adiante. No entanto, ele confere a essa teoria um âmbito mais amplo do que aquele que DENTI entendeu possível para a coisa julgada parcial, o que aproxima sua construção daquelas teorias que entendem possível a irrestrita formação de coisa julgada sobre questões.

${ }^{448}$ Como registram ANTONIO GIDI, JOSÉ MARIA ROSA TESHEINER e MARÍLIA ZANELLA PRATES, "o instituto da issue preclusion é muito interessante e, ao menos do ponto de vista teórico, sua validade é irretorquível. Todavia, na prática, a necessidade de se analisar a presença de cada um desses requisitos torna-se um grande problema, que inviabiliza sua aplicação. (...)definir se uma questão surgida em uma demanda é idêntica à outra decidida em demanda anterior é um dos problemas mais difíceis na aplicação da issue preclusion (...) Estabelecer se uma questão foi efetivamente controvertida entre as partes em um determinado processo tampouco é tarefa simples. E a questão também deve ter sido expressamente decidida pelo juiz na demanda anterior, o que nem sempre ocorre (...)A análise de todos esses requisitos pode tomar muito tempo das cortes e demandar um nível de energia desproporcional ao resultado, tornando os processos desnecessariamente mais complexos e demorados" (Limites objetivos da coisa julgada no projeto de Código de Processo Civil: reflexões inspiradas na experiência norte-americana. Revista de Processo, São Paulo, n. 194, abr. 2011, grifos nossos)

${ }^{449}$ MOTELEONE, Girolamo. I limitti soggettivi del giudicato civile, cit., p. 85.
} 
É também essa a crítica que é dirigida à tese do collateral estoppel por RODOLFO DE CAMARGO MANCUSO, em um raro texto de doutrina brasileira em que se discute a temática da coisa julgada sobre questões, manifestando a "a preocupação de fazer com que a coisa julgada, propriamente dita, opere sobre a lide no sentido próprio da palavra, evitando-se a cristalização das demais "questões-satélites", ainda quando estas tenham sido utilizadas, incidenter tantum, para compor o caminho lógico que conduziu à solução do âmago da demanda" ${ }^{450}$. Segundo MANCUSO, a disciplina dos limites objetivos da coisa julgada tem por finalidade "compor estes dois termos aparentemente contraditórios: a necessidade social e jurídica de que os litígios se extingam quando atingido um certo ponto de maturação do debate judicial e a necessidade (também social e jurídica) de se colocar limites a essa estabilização, visto que as relações jurídicas, tanto quanto as relações humanas, se interagem e se alteram, compondo novos "mosaicos",451. Dessa forma, a eventual incoerência lógica na apreciação de questões incidentais em processos sucessivos seria uma contingência necessária do sistema.

De outro lado, Giovanni Pugliese, em seu conhecido verbete para a Enciclopedia del diritto, seguiu a trilha iniciada por REDENTI e interpretou o conceito de coisa julgada a partir presente no art. 2.909 do Código Civil italiano não exigiria necessariamente um accertamento sobre o diritto fato valere, e dessa forma chega à conclusão que também as decisões isoladas de questões no curso do processo podem fazer coisa julgada ${ }^{452}$. A premissa adotada por PUGLIESE nesse texto, de certa maneira, é a mesma de que partiu ChiovendA: a de que entre preclusão e coisa julgada não haveria meio-termo possível. Enquanto este analisou o fenômeno dos vínculos externos da sentença parcial de mérito (que não define a lide, mas apenas questões), a partir do ângulo da coisa julgada material,

\footnotetext{
${ }^{450}$ MANCUSO, Rodolfo de Camargo. Coisa julgada, "collateral estoppel” e eficácia preclusiva "secundum eventum litis". Revista dos Tribunais, São Paulo, n. 608, jun. 1986.

${ }^{451}$ MANCUSO, Rodolfo de Camargo. Coisa julgada, "collateral estoppel” e eficácia preclusiva "secundum eventum litis"., cit.

${ }^{452}$ Em seu extenso verbete, PUGLIESE não chega a desenvolver de forma mais detalhada sua fundamentação para a afirmativa de que a decisão de questões possa constituir objeto da coisa julgada. $\mathrm{O}$ assunto é tratado em uma nota de rodapé, em que o autor, criticando a afirmação de REDENTI no sentido de que a coisa julgada sobre questões tem uma eficácia menos intensa do que o julgado ordinário, a refuta com o raciocínio de que "amessa l'efficacia della sentenza fuori del processo in corso, si recade necessariamente nell'art. 2909 c.c., poichè un tipo intermedio di efficacia tra quella endoprocessuale (propria della semplice preclusione, non del giudicato) e quella del giudicato sostanziale non sembra ammissibile. Solo il preconcetto che il giudicato debba di necessità riferirsi a una situazione di diritto sostanziale (a un $<<$ bene della vita $>>$ ) potrebbe indurre a creare la strana figura di un giudicato <<pan-processuale>>" (Giudicato civile: diritto vigente, cit., p. 837). O que se denota da passagem, portanto, é que a concepção de PUGLIESE é retirada exclusivamente da interpretação do artigo 2.909 do Código de Processo Civil italiano, sem maiores considerações em torno da teoria da jurisdição, onde se encontram as verdadeiras limitações para a determinação do conteúdo mínimo da coisa julgada.
} 
rejeitando esse enquadramento, o primeiro rejeitou a possibilidade de enquadrar o fenômeno como preclusão, na medida em que o conceito mesmo de preclusão foi por ele rejeitado em favor de uma concepção mais ampla do "giudicato".

O que ambos os autores demonstram, ao cabo, é que essa peculiar eficácia externa das sentenças parciais de mérito não se ajusta bem a nenhuma das figuras sugeridas. Pois de fato, se a preclusão explica mal o fenômeno, também a aplicação da coisa julgada sobre questões cujo conteúdo não julgue integralmente uma pretensão concreta se evidencia muito problemática.

Os inconvenientes em que incorrem as teorias que admitem a formação de coisa julgada, com eficácia para todos e quaisquer processos futuros, sobre questões são os mesmos que levam a moderna teoria da coisa julgada a repelir a possibilidade de se tornarem indiscutíveis os elementos lógicos contidos na motivação da sentença. De um lado, há o problema da abstração desse tipo de decisão, que ao desvincular a decisão da questão da tutela a algum direito em concreto, ignora que as diversas questões de fato e direito podem ter diferente relevância, e assumir distintos contornos, a depender de qual seja o contexto da norma de direito material em que se fundem as diferentes pretensões que a partir delas possam ser imaginadas. Exatamente em razão dessas múltiplas e imprevisíveis aplicações que a resolução da questão pode assumir para diferentes efeitos jurídicos, a sua admissão como objeto autônomo de um processo, apto a adquirir autoridade de coisa julgada, é fator que viola o direito de defesa do réu, que nunca poderá conhecer em toda a sua extensão as implicações do pedido que contra ele é dirigido. Tais inconvenientes nos levam a rejeitar, também, as teorias que admitem uma irrestrita formação de coisa julgada sobre questões.

\subsubsection{Teoria da coisa julgada sobre a fattispecie parcial}

Como o direito objetivo continuava a prever eficácia extraprocessual a sentenças parciais de mérito, que não definiam o direito aplicável ao caso concreto, a questão da natureza desse vínculo permanecia em aberto: não bastava rejeitar a sua classificação como preclusão ou como coisa julgada, embora a insuficiência das duas categorias já houvesse sido demonstrada. A superação do impasse foi possível, contudo, a partir de algumas observações, de extrema argúcia, feitas por VITTORIO DENTI em um artigo de 1958, I giudicatti sulla fattispecie. Esse trabalho abriu as portas para que se pudesse falar em um 
novo modo de ser da coisa julgada incidente sobre as sentenças parciais, inconfundível com a coisa julgada material em sentido estrito ${ }^{453}$ ou com a preclusão.

A sua concepção da imutabilidade desse tipo de decisão viria ainda a ser desenvolvida em dois artigos posteriores, Sentenze non definitive su questioni preliminari di merito e cosa giudicata (1969) e Ancora sull'efficacia della decisione di questioni preliminari di merito (1970), ao fim do que se atingiu um resultado que, segundo nos parece, superou com vantagem as diferentes explicações que a doutrina havia concebido anteriormente para explicar os vínculos extraprocessuais exercidos pela sentença parcial. Segundo a teoria de DENTI, em tais casos a coisa julgada não se forma sobre o efeito jurídico, mas sobre alguns dos elementos constitutivos do suporte fático da pretensão ${ }^{454}$. $\mathrm{O}$ juiz não chega a verificar se deles decorre a alteração de direitos, poderes ou situações jurídicas que constituem objeto da pretensão, mas ainda assim ele decide as questões prévias tendo em vista uma pretensão concreta às quais a análise dessas questões de fato ou direito é subordinada e em cujos limites ela se confina.

A grande contribuição da teoria, e o avanço em relação à concepção que defendia a formação de coisa julgada material sobre pontos de fato ou de direito, aos quais não se ligava qualquer efeito jurídico, está em ter enxergado o autor que, mesmo ao resolver questões em uma sentença que julga apenas parcialmente o mérito de uma determinada pretensão, o juiz tem sempre em vista uma situação concreta; não uma hipótese abstrata de aplicação. Precisamente por essa vinculação ao caso concreto, DENTI insiste em que a

\footnotetext{
${ }^{453}$ Nesse sentido, DOMENICO DALFINO critica a utilização da expressão "coisa julgada" (giudicato) como enganosa, porque na verdade DENTI estaria descrevendo um fenômeno diverso: "la ricostruzione, pur raffinata e affascinante, è apparsa fuorviante, poichè, quando si riferisce al giudicato, non intende l'accertamento pieno in ordine al'esistenza o inesistenza del diritto fatto valere in giudizio, ma la situazione che consegue alla decisione su una parte soltanto dell'oggetto del giudizio (la fattispecie, appunto, non anche l'effetto giuridico), che è qualcosa di diverso, di ampieza inferiore" (Questioni di diritto e giudicato: contributo allo studio dell'ccertamento delle "fattispecie preliminari". Torino: G. Giappichelli Editore, 2008. p. 226). SERGIO MENCHINI também afirma que não se pode falar de coisa julgada na hipótese, mas de uma "eficácia própria" limitada aos processos voltados aos demais aspectos da fattipecie (MENCHINI, Sergio. Il giudicato civile, cit., p. 278-279). Cabe assinalar que, à parte a polêmica quanto à questão terminológica, VITTORIO DENTI deixa bem delineada, em seu texto, em que medidas a coisa julgada sobre a fattispecie se distancia da coisa julgada em sentido estrito.

454،"Essenziale è, dunque, che non l'effetto giuridico (con che si avrebbe una pronuncia di accertamento pieno), ma la fattispecie, nei suoi elementi constitutivi, è oggetto di decisione vincolante, onde la possibilità di un diverso accertamento discende non da una diversa riconstruzione della medesima fattispecie, ma dalla possibilità di accertamento di una fattispecie diversa. (...) la nota distintiva, rispetto all'accertamento <<pieno>>, che è proprio delle normali pronunce giurisdizionali, è quindi data dall'essere escluso all'integrale verificarsi delle fattispecie dei diritti, poteri o stati giuridici oggetto del processo. (...) Non è meno concreta, quindi, nell'un caso che nell'altro, la statuizione, che pressupone sempre l'esercizio del potere giurisdizionale in ordine ad una fattispecie ben determinata, e non è mai nè semplice opera di storico, nè semplice opera di consulente"' (DENTI, Vittorio. I giudicati sulla fattispecie. In: Scritti giuridici in memoria di Piero Calamandrei. Padova: CEDAM, 1958. v. 3, grifos nossos).
} 
construção não é incompatível com o conceito de coisa julgada, embora nessas circunstâncias ela se manifeste com uma intensidade inferior ${ }^{455}$.

E se fala em menor intensidade porque, se é verdade que a decisão do juiz sobre essas questões, atinentes ao "processo parcial”, são dotadas de eficácia vinculante extraprocessual equivalente ao efeito positivo da coisa julgada (indiscutibilidade), essa eficácia não vale para todos e quaisquer processos futuros, mas é limitada apenas àqueles em que os elementos restantes da mesma fattispecie concreta são levados a juízo. Assim, a sentença parcial não prescinde de futuras sentenças complementares voltadas ao exaurimento da cognição a respeito do mesmo caso concreto, e é apenas neles que se fará sentir a força do julgado parcial. A determinação ou negativa do efeito jurídico pretendido pelo autor (a pretensão à tutela jurídica), de seu turno, resultará da conjunção das duas sentenças.

Em uma comparação com a doutrina precedente, a diferença da construção de VITTORIO DENTI em relação à teoria da “coisa julgada sobre questões” de ENRICO REDENTI e de Pugliese, ou ao transporte que MiChelle TARUFFo viria a propor do colateral estoppel do direito norte-americano, está em que para ele a coisa julgada sobre elementos do suporte fático não é autônoma, mas subordinada à decisão de um caso concreto, e seus efeitos somente se fazem sentir em outros processos em que esse mesmo caso é discutido ${ }^{456}$. Por isso, não há qualquer impedimento a que um juiz de processo futuro decida a mesma questão em sentido contrário, se outra for a lide e outro o bem da vida em discussão.

A construção da coisa julgada parcial sobre a fattispecie parcial vem sendo aceita pela doutrina, com a ocasional ressalva de alguns autores em identificar essa eficácia específica com o termo “coisa julgada”. É o caso de SERGIO MENCHINI, que fiel à concepção chiovendiana que reserva a coisa julgada às decisões de mérito que atribuam ou negue um bem da vida em caráter definitivo, reconhece uma "eficácia própria" a esse tipo de decisão. ${ }^{457}$ DOMENICO DALFINO, afirmando que as diferentes formas pela qual o juiz

\footnotetext{
${ }^{455}$ De fato, embora insista que se trata de coisa julgada, DENTI é claro em afirmar que ela não se manifesta tal e qual a coisa julgada sobre a sentença definitiva: “(...) è pur necessario ammetere la possibile minore intensità di effetti di questo accertamento rispetto agli accertamenti con contenuto <<pieno>>” (DENTI, Vittorio. I giudicati sulla fattispecie, cit.)

456، (...) Il processo, rispetto al quale il giudicato sulla fattispecie spiega l'efficacia vincolante, è processo nuovo, e che la frattura prodottasi nella pendenza della lite comporta la naturale incidenza, su tale situazione, di effeti che discendono dall'applicazione di principii diversi" (DENTI, Vittorio. I giudicati sulla fattispecie, cit.).

457،Pur essendo esclusa l'idoneità della sentenza di condanna generica ad acquistare autorità di cosa giudicata, sideve, tuttavia, sottolineare che essa, in forza del combinato disposto degli artr. $310,2^{\circ}$ comma, c.p.c., e $129,3^{\circ}$ comma, disp. att. c.p.c., conserva la propria efficacia, in caso di estinzione dell'ulteriore fase del processo volta alla liquidazione del danno; questo porvvedimento, infatti, contiene sì una pronunzia parziale, poiché decide una parte soltanto delle questioni controverse, ma, nel rispetto dei propri limiti
} 
resolve as questões da lide implicam em diversos níveis de "eficácia" "458, considera preciosa a intuição que está à base da teoria da coisa julgada sobre a fattispecie, na medida em que a vinculação do juiz em processos futuros em que sejam discutidas outras questões relacionadas à mesma fattispecie concreta se dá, tal como na coisa julgada, em sentido preclusivo (eficácia negativa) e conformativo (eficácia positiva) ${ }^{459}$.

Há que se registrar que, ainda antes de DENTI, a idéia da coisa julgada parcial, como elemento para a formação progressiva do julgado, havia sido sugerida por CARNELUTTI $^{460}$ (justamente o autor que havia se aprofundado no estudo das relações entre a lide e o processo e havia criado o conceito de processo parcial). Embora o autor tenha abordado o assunto de forma ocasional e não sistematizada, pensamos que os resultados por ele atingidos são assimiláveis à construção que estamos a examinar, na medida em que nesse caso a coisa julgada não assumiria eficácia panprocessual, mas apenas uma eficácia circunscrita à lide. Essa faceta de seu pensamento sobre a coisa julgada parcial é bem evidenciada no artigo Capo di sentenza, de 1933, em que ele afirma, de maneira equilibrada, que "le soluzioni delle questioni passini in giudicato, e meglio si direbbe abbiano forza imperativa o vincolante, è vero si e no, secondo il significato que si dà a questa frase. Il vero è che ciò che obbliga non è la soluzione delle questione in sè, cioè rispetto a qualunque lite, ma solo rispetto alla lite da qua agitur. Io ho cercato di esprimere

\footnotetext{
oggetivi, ossia con riferimento alle questioni risolte, è decisione esauriente di merito, non sommaria o provvisoria. La statuizione in esame è dotata di efficacia panprocessuale, ossia impedisce di rimettere in discussione le questione che hanno costituito l'oggetto del processo sull'an debaeatur, all'interno del giudizio relativo alla determinazione del quantum; ciò significa che essa è di ostacolo ad ogni ulteriore discussione in ordine alla illiceità del comportamento tenuto dal daneggiante, vuoi sotto il profilo oggetivo (injuria) vuoi dal punto di vista soggetivo (colpa), mentre lascia impregiudicata ogni questione relativa agli elementi della fattispecie che sono rimasti esclusi dalla tratazione nel procedimento di condanna generica: sussistenza del nesso causale ed effetiva sussistenza del danno. Più precisamente, la giurisprudenza ha così determinato i limiti oggetivi di efficacia della sentenza di condanna generica." (MENCHINI, Sergio. Il giudicato civile, cit., p. 278-279).

${ }^{458}$ “Nel caso delle sentenze non definitive su questioni, non sembra correto (e opportuno, al fine di evitare equivoci di ordine terminologico o concettuale) paralre di giudicato sostanziale; si tratta, infatti, di efficacia vincolante nei sucessivi processi in cui sia riproposta la stessa domanda tra le stesse parti" (DALFINO, Domenico. Questioni di diritto e giudicato: contributo allo studio dell'ccertamento delle "fattispecie preliminari”, cit., p. 225).

${ }^{459}$ DALFINO, Domenico. Questioni di diritto e giudicato: contributo allo studio dell'ccertamento delle "fattispecie preliminari”, cit., p. 227.

${ }^{460}$ Em um breve comentário a julgado da Corte de Cassação italiana que admitira o reexame de sentença genérica dada no mesmo processo da liqüidação, CARNELUTTI defendeu que independentemente de a sentença genérica ter sido proferida em um processo distinto ou no mesmo processo, ela seria igualmente protegida pela coisa julgada, com a única peculiaridade de que ela seria parcial. "Anche la conoscenza del gioudicato ha fatto, pocoa poco, la sua strada. Chiovenda ha percorso un bon tratto, ma neppure lei poteva arrivare fino in fondo. Ciò che gli è mancato è stato il concetto del giudicato parziale o, in altri termini, della formazione progressiva del giudicato. Questo è un fenomeno parallelo a quello della formazione progressiva del contratto (o, in genere, del negozio), il quale è pure una cojnquista recente del pensiero scientifico." (Cosa giudicata parziale. Rivista di Diritto Processuale, Padova, v. 2, p. 179, 1956).
} 
questa verità parlando di due dimensione della cosa giudicata, che sono la lite e la questione: la c.g. nè riguarda questione della medesima lide non dedotte nel processo, nè identiche questioni di liti diverse" ${ }^{\text {461 }}$. Entretanto, o fato é que essa linha de pesquisa não foi objeto de desenvolvimentos posteriores pela doutrina, que percorreu uma trilha diversa para anos depois chegar a conclusões que se revelam muito parecidas em sua substância. Podem ter pesado para isso as circunstâncias de que o tema da coisa julgada parcial não foi desenvolvido de forma mais sistematizada por CARNELUTTI, mas também não se pode excluir que as severas críticas dirigidas ao conceito de lide, e o descrédito que elas geraram sobre o conceito de processo parcial, tenham obscurecido sua incursão pioneira nesse campo de indagações.

A limitação da coisa julgada parcial ao caso concreto é a chave que consegue compatibilizar a estabilização de simples questões, que não consistam em uma relação jurídica concreta, à moderna teoria da jurisdição e da coisa julgada. Na medida em que se limita a coisa julgada parcial a processos que se voltem ao exame fracionado de uma mesma fattispecie, a indiscutibilidade das premissas lógicas de mérito não irá produzir a violação ao direito de defesa do réu. Isto é assim porque a finalidade última para qual se está a discutir determinado ponto de fato ou direito é desde logo conhecida pelas partes, ainda que o processo não venha a esgotá-la, de modo que não haverá surpresa sobre as conseqüências últimas da decisão. As possíveis repercussões do julgado sobre processos futuros são previamente conhecidas das partes.

Em suma, a abrangência da coisa julgada sobre a fattispecie parcial pode ser considerada sob dois pontos de vista. Ela é mais restrita do que a coisa julgada comum na medida em que a sua eficácia extraprocessual não se aplica a todos e quaisquer processos em que as questões resolvidas possam ter alguma repercussão, mas somente naqueles que tenham por objeto a mesma lide (ou fattispecie concreta), identificada pela afirmação de uma mesma relação jurídica entre as partes. Ela vale para alguns processos futuros, mas não para todos e quaisquer processos futuros. Por outro lado, ela é mais ampla, pois os vínculos que ela irradia sobre os juízes de processos futuros compreendem não apenas a conclusão última sobre uma questão determinada (que a rigor não ocorre no processo parcial), mas todos os elementos integrantes do suporte fático que já tenham sido

${ }^{461}$ CARNELUTTI, Francesco. Capo di sentenza. In: . Studi di processo civile. Padova: Cedam, 1939, v. 3, p. 106. 
resolvidas no processo anterior. Isto significa dizer que a coisa julgada parcial incide sobre as questões prejudiciais, e não sobre o dispositivo.

Para se visualizar o modo como funciona a coisa julgada parcial, podemos considerar que esse complexo de processos “parciais” voltados a uma mesma situação concreta constitui um sistema à parte, dotado de relativa autonomia, em que as etapas lógicas do raciocínio necessário à decisão do mérito se dividem. As sentenças parciais assumem um caráter instrumental, e vinculam intensamente as decisões futuras apenas dentro desse mesmo complexo de processos voltados à solução da lide unitária; mas não têm nenhuma relevância no ambiente externo, ou seja, as mesmas questões podem ser resolvidas de maneira diferente se for outra a pretensão em julgamento. A coisa julgada material, propriamente dita, somente é atingida a partir da combinação das sentenças parciais, quando todos os elementos do suporte fático relativos a um direito em concreto são apreciados. E nesse sentido, a teoria vai ao encontro da idéia de "formação progressiva do julgado" sobre os capítulos de sentença ${ }^{462}$.

\subsubsection{O tratamento doutrinário e jurisprudencial do princípio da "fidelidade da liqüidação ao título"}

Como já afirmamos, nem a sentença parcial, e tampouco a natureza do vínculo que ela exerce sobre os juízes dos demais processos (também parciais) que visam a integrar a resolução da lide foram objeto de estudos mais aprofundados por parte da doutrina brasileira. Isto pode ser atribuído, a nosso ver, pelo caráter absolutamente residual que esse tipo de processo encontra na disciplina de nosso direito processual. Como vimos, a divisão do julgamento da lide é permitida em poucos procedimentos especiais, como a ação de prestação de contas ou procedimento da desapropriação por utilidade pública. A hipótese prática mais freqüente em que se dá esse desdobramento lide (entendida como pretensão processual) em mais de uma relação processual, contudo, reside na permissão excepcional que o artigo 286 do Código de Processo Civil abre à formulação de pedido genérico, quando: (i) nas ações universais, se não puder o autor individuar na petição os bens demandados; (ii) não for possível determinar, de modo definitivo, as consequiências do ato

${ }^{462}$ LIEBMAN, Enrico Tullio. $<<$ Parte $>>$ o $<<$ capo $>>$ di sentenza. Rivista di Diritto Processuale, Padova, p. 55, 1964. A idéia de formação progressiva do julgado, acolhida por LIEBMAN, havia já sido sugerida por CARNELUTTI anos antes. 
ou do fato ilícito; ou (iii) a determinação do valor da condenação depender de ato que deva ser praticado pelo réu.

Esse espaço residual que o direito brasileiro confere ao processo parcial, e particularmente ao pedido genérico, se circunscreve a situações em que se faz improvável a "liqüidação zero", ou seja, o esvaziamento de utilidade prática da primeira sentença por se verificar insubsistente o dano, de modo que pouco interesse despertou o assunto sob o prisma da teoria da coisa julgada. Trata-se de um cuidado que foi adotado pelo legislador para que o tempo e os recursos investidos no processo não fossem, dentro do possível, desperdiçados com uma decisão que infirmasse a primeira sentença. Embora ao processo parcial tenha sido destinado um espaço reduzido, entretanto, ele permaneceu no sistema. $\mathrm{E}$ assim, as questões relacionadas à estabilidade da sentença genérica foram objeto de consideração pela doutrina e pela jurisprudência, ainda que de forma pouco sistematizada, por referências vagas à coisa julgada ou àquilo que se convencionou chamar de "princípio da fidelidade da liqüidação ao título", consubstanciado no artigo 475-G do Código de Processo Civil.

Duas foram as principais questões em que o princípio se viu utilizado. A primeira delas diz respeito à possibilidade da "liqüidação-zero", isto é, se existiria violação à coisa julgada caso o processo de liqüidação concluísse pela insubsistência de dano. A segunda concerne às quais questões vinculam ou deixam de vincular o juiz no processo de liqüidação. Nesse sentido, convergem doutrina e jurisprudência no sentido de admitir a ampla vinculação do juízo da liqüidação a todas as questões de fato ou direito resolvidas pela sentença genérica ${ }^{463}$, de modo que o âmbito da regra da fidelidade pode se considerar mais alargado do que o da coisa julgada material, centrado apenas no dispositivo da sentença (art. 469 do Código de Processo Civil). De outro lado, no próprio nome do instituto a que se refere a doutrina brasileira encontra-se exposta a diretriz de que essa

\footnotetext{
${ }^{463}$ De acordo com LUIZ RODRIGUES WAMBIER, na liqüidação é “(...) defeso qualquer nova discussão a respeito de questões que envolvam a própria formação do título" (WAMBIER, Luiz Rodrigues. Liqüidação da sentença civil: individual e coletiva, cit., p. 151). No âmbito do Superior Tribunal de Justiça, essa orientação foi aplicada no agravo regimental em recurso especial n. 303.536-SP, que decidiu que "não constitui ofensa à coisa julgada a limitação da liqüidação de título judicial às questões enfrentadas $e$ decididas na fase de conhecimento, adequando-se a parte dispositiva do acórdão à sua fundamentação" (Primeira Turma, rel. Min. DENISE ARRUDA, j. 14.12.2004, p. DJ 01.02.2005, destaque nosso). Tendo o acórdão em liqüidação descaracterizado como danos determinadas verbas que a anterior sentença genérica assim havia qualificado, decidiu também o mesmo Superior Tribunal de justiça que "afronta aos limites da prestação jurisdicional pelo Tribunal de origem ao transmutar o conteúdo da coisa julgada, posto que decidiu novamente questões que já haviam sido discutidas e debatidas no referido processo cognitivo, estando acobertadas pelo manto da inalterabilidade. Inteligência dos arts. 467, 468, 471 e 610, todos do Código de Processo Civil" (Recurso Especial no 263.257-MG, Quinta Turma, rel. Min. GILSON DIPP, j. 07.06.2001, p. DJ 03.09.2001, destaque nosso).
} 
vinculação a fatos e questões não adquire projeção panprocessual, permanecendo restrita ao processo de liqüidação que visa à integração dos elementos faltantes na sentença genérica.

Por fim, ao examinar a questão da "liqüidação-zero", a ampla maioria da doutrina também reconhece ao juízo da liqüidação plena liberdade em resolver as questões que não foram tratadas na sentença genérica, concluindo que a declaração da inexistência do direito nessa fase do processo não ofende "a coisa julgada" 464 .

Em conclusão, portanto, verifica-se que sob a denominação da "fidelidade da liqüidação ao título", tanto a doutrina como a jurisprudência brasileira reconhecem a vinculação do juiz da liqüidação a questões prejudiciais resolvidas no processo que definiu o an debeatur, fundando essa interpretação no artigo 468 do Código de Processo Civil. E de outro lado, a corrente majoritária entende possível discussões ulteriores sobre a condenação caso não se comprove a existência do dano na ação de liqüidação, reconhecendo a possibilidade da chamada "liqüidação-zero" sem enxergar nisso violação à res judicata. Embora esses dois temas sejam enfrentados a partir da teoria da coisa julgada, portanto, o que se verifica é que as soluções encontradas sob o princípio da fidelidade ao título discrepam daquelas que estariam associadas à disciplina tradicional da coisa julgada. Mas em que pese a pouca sistematização, os problemas práticos gerados pela sentença parcial de mérito foram tratados com sensibilidade para a peculiaridade desse tipo de decisão, e conduziram a resultados que são compatíveis com a teoria da coisa julgada parcial sobre a fattispecie.

\footnotetext{
${ }^{464}$ De fato, a doutrina associa o princípio da fidelidade da liqüidação ao título à coisa julgada, como se vê ARAKEN DE ASIS, que afirma "que a impossibilidade de discutir de novo a lide (...) se prende, na execução definitiva, à autoridade da coisa julgada" (Cumprimento de sentença, cit., p. 99). È também o ângulo sob o qual a questão foi enfrentada por doutrina e jurisprudência, conforme dá notícia EGAS MONIZ DE ARAGÃO: “esse resultado não infringe a 'condenação' (na verdade simples declaração 'de uma hipotética responsabilidade por um dano meramente possível'); não ofende a 'coisa julgada', como supõem erroneamente os que não aprofundam o estudo do assunto e se contentam em examiná-lo pela rama. (...) Se a existência e o valor do dano não houverem sido demonstrados no processo de conhecimento, a tentativa de sua apuração na fase da liqüidação da sentença poderá revelar que não há dano a ressarcir, 'o quantum é igual a zero'. Sempre que isso ocorrer, ninguém poderá negar que a única solução honesta para tal caso é a preconizada pelo ‘íntegro Juiz Arthur Ribeiro', isto é, o 'dogma jurídico' de que o STF fez o elogio: 'Entre deixar a sentença sem execução e condenar sem provas, é preferível a primeira solução"” (Notas sobre liqüidação de sentença, cit., p. 21-30).
} 


\subsection{A decisão parcial sobre a fattispecie e a coisa julgada coletiva}

Examinadas as três teorias que buscam explicar os vínculos gerados pelas sentenças parciais, e tendo se concluído pelas vantagens da teoria de VITTORIO DENTI em torno da formação de uma coisa julgada sui generis, caracterizada pela sua limitação à parcela do suporte fático sobre a qual se decidiu e com sua eficácia vinculante extraprocessual restrita ao mesmo caso concreto, o propósito desta seção é investigar a adaptabilidade dessa teoria à sentença genérica coletiva de que trata o art. 95 da Lei n. 8.078/90.

Antes disso, buscaremos enfrentar duas questões antecedentes, relacionadas à propriedade de se falar em coisa julgada diante da sentença genérica coletiva. A primeira delas consiste em uma breve análise do panorama da estabilidade das sentenças proferidas nos separated trials da experiência norte-americana, cuja técnica da "bifurcação" de processos complexos foi uma das fontes inspiradoras do Código de Defesa do Consumidor. E a segunda consiste na tese de que a sentença genérica coletiva irradia apenas eficácia material, e não se constituiria propriamente em objeto da estabilidade proporcionada pela coisa julgada, o que implicaria em que a regulamentação trazida pelo Código do Consumidor nada de novo trouxe em relação à disciplina que já existia no Código de Processo Civil.

\subsubsection{Estados Unidos: as issue class actions e a reexamination clause}

Como vimos no primeiro capítulo, uma das inspirações da técnica de divisão da atividade cognitiva da ação civil coletiva brasileira pode ser encontrada nas class actions norte-americanas, em que é aberta ao juiz a possibilidade de estabelecer um plano de trabalho que "bifurque" a ação de classe em duas ou mais fases voltadas à discussão de questões específicas $^{465}$. Evidentemente, para que o trabalho desempenhado em cada uma delas não se perca, é necessário que de alguma forma seja dada estabilidade ao que ficar decidido em cada uma das fases desse procedimento "bifurcado". Por isso, é conveniente estudar qual o tratamento dado ao tema naquele país.

\footnotetext{
${ }^{465}$ Federal Rules of Civil Procedure, Rule 23, (c), (4): "Particular Issues: When appropriate, an action may be brought or maintained as a class action with respect to particular issues"
} 
De início, é necessário advertir que o direito norte americano não conta com uma teoria da coisa julgada bem sistematizada, e isso é criticado pela doutrina como um fator que inibe o juízo de admissibilidade em ações que poderiam muito bem ser recebidas se houvesse uma disciplina mais clara a respeito do assunto ${ }^{466}$. A coisa julgada, em si mesma, tem regramento assemelhado ao do direito continental. Somente há coisa julgada em decisões que se pronunciem sobre o mérito da causa (on the merits). Os limites da coisa julgada exigem a tríplice identidade: devem coincidir as partes, (parties), o pedido (claim) e a causa de pedir (cause of action). O conceito de cause of action tem abrangência mais ampla do que a causa de pedir de nosso direito, e envolve todos os fatos relacionados a um mesmo contexto de relação entre as partes, que se designa de transaction $^{467}$. Atendidos esses requisitos, surgirá a claim preclusion (a que se refere em textos mais antigos como “res judicata”), que excluirá um novo julgamento sobre a mesma causa. As questões prejudiciais decididas no curso da sentença podem também ser abrangidas pela coisa julgada, no instituto conhecido como issue preclusion (ou "collateral estoppel", em terminologia um pouco mais antiga), também nisso se aplicando a crítica quanto à falta de clareza dos critérios que permitem essa vinculação ${ }^{468}$. Essas são as linhas gerais do tratamento da coisa julgada.

Mas no caso específico dos julgamentos parciais (“bifurcated”), a natureza dos vínculos irradiados para os processos complementares não é tratada naquele país exclusivamente sob o prisma da coisa julgada. Nos procedimentos bifurcados, tanto como nos procedimentos comuns, existe a peculiaridade de que as questões normalmente são decididas por um júri. O julgamento pelo júri é um direito constitucional no sistema norte-

\footnotetext{
${ }^{466}$ WOLFF, Tobias Barrington. Preclusion in class action litigation. Columbia Law Review, v. 105, p. 717$808,2005$.

${ }^{467} \mathrm{O}$ conceito de transaction ocupou nos últimos anos o papel de unidade mínima da estrutura processual no direito norte-americano, até então era desempenhado pelo conceito de writ, gerando o alargamento dos limites da coisa julgada e do efeito de exclusão sobre novas demandas (TIDMARSH, Jay; TRANSGRUD, Roger. Complex litigation: problems in advanced civil procedure, cit., p. 7-8). É interessante observar que a causa de pedir, alargada pelo conceito de transaction, acaba por produzir resultados práticos muito similares aos que o direito espanhol, de tradição completamente distinta, introduziu recentemente por meio da preclusão de causas de pedir presente no art. 400 da LEC/2000. Por essas diferentes vias, nos dois regimes as partes são obrigadas a deduzir todas as possíveis causas e pretensões que decorram de um mesmo contexto de relacionamento fático-jurídico, sob pena de não poderem promover um segundo processo para invocar um título ou uma pretensão não deduzidos na primeira demanda.

${ }^{468}$ Em estudo comparativo do regime da coisa julgada norte-americana, com especial consideração para a issue preclusion, e os regimes atual (art. 469, CPC) e projetado (art. 490, PLS/166) de tratamento das questões prejudiciais no direito brasileiro, ANTONIO GIDI, JOSÉ MARIA TESHEINER e MARÍLIA PRATES anotam que os requisitos para o reconhecimento da issue preclusion são fonte de insegurança, na medida em que nem sempre é fácil identificar os requisitos que permitem a extensão da coisa julgada sobre questões a um processo futuro (Limites objetivos da coisa julgada no projeto de Código de Processo Civil: reflexões inspiradas na experiência norte-americana, cit.).
} 
americano, de acordo com a Sétima Emenda à Constituição, em todas as causas cujo valor exceda a vinte dólares (embora as partes possam eventualmente dispensá-lo).

E a mesma Emenda determina que "nenhum fato declarado por um júri deverá ser de outra maneira reexaminado, em nenhuma corte dos Estados Unidos, que não de acordo com as regras da common law." 469 Assim, a indiscutibilidade das questões de fato decididas na primeira fase do procedimento bifurcado não é analisada apenas sob a ótica da coisa julgada, mas também da Cláusula de Reexame da Sétima Emenda, o que confere uma estrita vinculação dos processos subseqüentes a cada um dos aspectos sobre os quais tenha se manifestado o júri no primeiro trial ${ }^{470}$.

\subsubsection{A coisa julgada secundum eventum litis e a definição do instituto como simples expansão de eficácia da sentença: crítica}

Ainda antes de examinarmos a adequação do modelo da coisa julgada sobre a fattispecie parcial à sentença genérica coletiva, faz-se necessário examinar se de fato aquela sentença produziria algo que se pode caracterizar como coisa julgada (ainda que dotada de caracteres próprios), ou se a nossa abordagem do instituto a partir dos postulados próprios à res judicata seria indevida e levaria à equivocada apreensão do objeto de nosso estudo. Essa preocupação ganha maior significação diante de uma proposta doutrinária que vê na coisa julgada sobre a ação genérica coletiva do Código de Defesa do Consumidor de simples expansão de eficácia natural da sentença perante terceiros, fenômeno já conhecido e bem exposto por LIEBMAN em sua fundamental monografia sobre a coisa julgada.

Este último modo de pensar o instituto foi sugerido por JosÉ IGNÁCIO BOTELHO DE Mesquita, em polêmico artigo em que esse autor afirmou que do Código de Defesa do Consumidor não inovou na disciplina da coisa julgada dos direitos individuais homogêneos, frente ao sistema do Código de Processo Civil. Afirmou ele, a respeito, que "se a ação for julgada procedente, estará inteiramente satisfeito o fim das ações

\footnotetext{
${ }^{469} \mathrm{O}$ texto da Sétima Emenda à Constituição norte-americana é o seguinte: "In Suits at common law, where the value in controversy shall exceed twenty dollars, the right of trial by jury shall be preserved, and no fact tried by a jury, shall be otherwise re-examined in any Court of the United States, than according to the rules of the common law." As hipóteses permitidas pela common law para o reexame dos fatos por um novo júri, às quais remete a parte final da fórmula, dizem respeito a hipóteses de error in procedendo no primeiro julgamento.

${ }^{470}$ Nesse sentido confiram-se RICHARD NAGAREDA, The law of class action and other aggregate litigation, cit., p. 252-256 e TIDMARSH, Jay; TRANSGRUD, Roger. Complex litigation: problems in advanced civil procedure, cit., p. 228-231.
} 
concorrentes, nada importando que a sentença se torne indiscutível ou não; não haverá

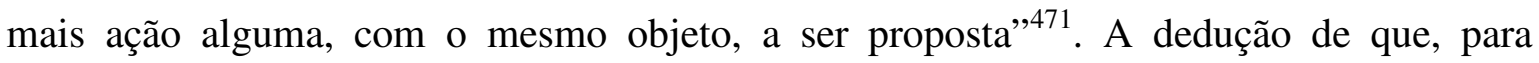
Botelho DE MESQuitA, a coisa julgada coletiva consistiria na expansão da eficácia natural da sentença genérica deriva da assimilação da ação coletiva à figura das ações concorrentes (especificamente, o concurso subjetivo em que há pluralidade de partes legitimadas para impugnar um mesmo ato), pois nos termos da lição de LIEBMAN, esse é o mecanismo pelo qual os demais legitimados concorrentes, que não se vinculam à coisa julgada, se beneficiam da sentença dada em processo alheio ${ }^{472}$.

Na monografia de José RogÉRIO CRUZ E TUCCI sobre os Limites subjetivos da eficácia da sentença e da coisa julgada civil, essa mesma idéia aparece de forma mais explícita, afirmando o professor do Largo de São Francisco que o art. 103, inciso III da Lei n 8.078/90 abre duas possibilidades: “a) sentença de procedência do pedido: eficácia da sentença e extensão da coisa julgada a todos os titulares de direitos homogêneos; b) sentença de improcedência do pedido: b.1) limitação da coisa julgada apenas entre as partes, obstando o ajuizamento de novas demandas coletivas, por qualquer legitimado; e b.2) todos os membros do grupo, titulares de direitos subjetivos divisíveis, não são atingidos pelo julgamento desfavorável e, por esse motivo, podem, na posição de terceiros, propor ações individuais" ${ }^{473}$. Também afirmando de maneira explícita o vínculo gerado ela sentença genérica coletiva se resumiria na expansão da eficácia natural da sentença, alinham-se ADA PELLEGRINI GRINOVER ${ }^{474}$ e LUIZ GUILHERME DELLORE ${ }^{475}$.

Essa interpretação pode ser aceita apenas parcialmente, em nossa avaliação. Por um lado, há razão em se afirmar que o regime da coisa julgada coletiva segue sim o princípio

\footnotetext{
${ }^{471}$ BOTELHO DE MESQUITA, José Ignácio. A coisa julgada no Código do Consumidor, cit., p. 38.

${ }^{472}$ LIEBMAN, Enrico Tullio. Ações concorrentes, cit., p. 209-219. A teoria já foi exposta no segundo capítulo, item 4, desta dissertação.

${ }^{473}$ CRUZ E TUCCI, José Rogério. Limites subjetivos da eficácia da sentença e da coisa julgada civil, cit., p. 320. À diferença de BOTELHO DE MESQUITA, observe-se que JOSÉ ROGÉRIO CRUZ E TUCCI aplica aqui a sua tese de que a coisa julgada favorável, a despeito da letra do art. 472 do Código de Processo Civil, se estende a terceiros.

474، "No plano dos indivíduos substituídos, a coisa julgada - imutabilidade da sentença e seus efeitos - só vai atuar para beneficiá-los. Em caso de sentença desfavorável, não fará ela coisa julgada em relação aos indivíduos, titulares de direitos subjetivos divisíveis. Contra eles, existe apenas a eficácia natural da sentença, que poderá ser afastada mediante a propositura de ações individuais" (GRINOVER, Ada Pellegrini. Eficácia e autoridade da sentença: a teoria de Liebman no Código de Defesa do Consumidor e no Código Modelo de processos coletivos para Ibero-América. In: $O$ processo: estudos e pareceres. São Paulo: Perfil, 2005, p. 205).

${ }^{475}$ “'No caso de improcedência, o que teremos é a extensão subjetiva da coisa julgada a terceiros, ope legis; ao passo que no caso de procedência, haverá simples produção dos efeitos para terceiros, como sempre ocorreu (...)". DELLORE, Luiz Guilherme Pennacchi. Das sentenças que não são cobertas pela coisa julgada no direito processual civil brasileiro, cit., p. 175.
} 
sustentado por LIEBMAN para justificar a diferença na extensão subjetiva da eficácia da sentença e da coisa julgada, que é justamente a idéia de que alguém que não tenha participado do processo, integrando o contraditório, não pode ser prejudicado pela imutabilidade da sentença, embora possa se aproveitar da decisão ${ }^{476}$. Parece-nos inclusive que esse é o ponto principal que os autores acima citados quiseram deixar consignado, e nele não há qualquer reparo a ser feito.

No entanto, o que se irradia da sentença genérica coletiva em favor da coletividade substituída não são realmente efeitos da condenação, ou quaisquer tipos de efeitos, pois ela ainda não determinou a certeza do direito que incide no caso concreto. A sentença coletiva, embora decida questões importantes para a entrega final da tutela jurisdicional, é sentença incompleta, que ainda não tem condições de dispor sobre a eficácia jurídica pretendida pelo autor coletivo. A sentença parcial é sentença sem dispositivo, ou sentença com dispositivo incompleto se assim se preferir, mas que de qualquer modo não contém o juízo de subsunção que permita afirmar a incidência normativa e é insuficiente para a irradiação dos efeitos próprios à condenação ou mesmo à declaração.

Assim sendo, a sentença genérica não produz nenhuma alteração na realidade jurídico-material. Ela não constitui e nem extingue direitos; ela não permite a execução até ser integrada pelas demandas complementares; e ela tampouco vincula as partes a tomar como certa determinada relação jurídica. Isso se explica em razão da margem de incerteza gerada pela eventualidade de uma liqüidação zero, que não permite dizer que a causa tenha sido decidida. Por isso, pensamos que não é correto dizer que aquilo que a lei define como coisa julgada secundum eventum litis se constitui como a expansão da eficácia natural da sentença, nos termos da doutrina de LIEBMAN.

De outro lado, ela produz vínculos no plano do direito processual, pelos quais os juízes de processos futuros deverão observar o que restou decidido a respeito da responsabilidade genérica do réu da ação coletiva, isto é, sobre as questões comuns resolvidas pela sentença genérica ${ }^{477}$. Esse vínculo externo, que opera no plano processual,

\footnotetext{
${ }^{476}$ Conforme consta do encerramento de Eficácia e autoridade da sentença, "a diversidade de condição em que se acham as partes e os terceiros justifica-se por si só: aquelas e não estes puderam desenvolver sua defesa por meios legalmente estabelecidos" (cit., p. 145).

${ }^{477}$ No mesmo sentido, CAMILO ZUFELATO afirma ser “indispensável uma precisão: na hipótese de procedência da demanda coletiva não são os meros efeitos da sentença que atingirão os 'substituídos', mas sua própria autoridade, por expressa autorização legal (art. 103, $\S 2^{\circ}$, do CDC). Se se tratasse da transposição da mera eficácia da sentença, significaria que o demandado poderia discutir o an debeatur, o que não é possível, dada a excepcional transposição secundum eventum litis in utilibus da imutabilidade do comando judicial coletivo" (Coisa julgada coletiva, cit., p. 395-396).
} 
é uma nota característica do instituto da coisa julgada, razão pela qual consideramos, mesmo já sendo possível identificar que o instituto não é plenamente assimilável à coisa julgada material cuja disciplina se encontra no Código de Processo Civil, que a natureza processual do vínculo estabelece uma relação de afinidade entre ambos os fenômenos, que podem assim ser estudados como espécies de um mesmo gênero. Conseqüência disso é que a coisa julgada sobre a fattispecie parcial coletiva, embora tenha características que lhe assegurem autonomia como instituto jurídico diverso, pode de fato ser considerada, como o Código a denomina, uma espécie de coisa julgada secundum eventum litis.

\subsubsection{Coisa julgada "erga omnes" sob o enfoque da coisa julgada sobre a fattispecie parcial}

Como vimos mais cedo neste capítulo, a sentença de condenação genérica coletiva, de que trata o artigo 95 da Lei $n^{\circ}$ 8.078/90, consiste em uma modalidade de sentença parcial. Ela não exaure integralmente a cognição sobre os direitos que constituem seu objeto, deixando uma margem de incerteza sobre os elementos heterogêneos, que por serem de interesse particular de cada indivíduo que integra a classe, não podem ser examinados de maneira concentrada. Dessa forma, a ela se aplicam as dificuldades para aplicação da disciplina da coisa julgada que se verificam em todas as sentenças parciais: ela não fornece certeza, já que a sentença complementar pode concluir pela insubsistência da pretensão que foi parcialmente examinada; e estruturalmente ela não contém um dispositivo perfeito, fundado em um juízo conclusivo de mérito, mas apenas hipotético.

Não é com surpresa, assim, que a doutrina que se debruçou com mais cuidado sobre a condenação genérica coletiva tenha rejeitado a hipótese de formação de coisa julgada sobre esse tipo de decisão. Nesse sentido alinha-se a posição inaugurada por José IGNÁCIO Botelho De Mesquita, no sentido de considerar que ela irradia eficácia externa ao processo, mas não propriamente coisa julgada. Pelo fato de que o vínculo por ela irradiado é de natureza processual e não material, contudo, pensamos que essa explicação não é plenamente satisfatória ( $c f$. item 4.3.2, retro), muito embora o diagnóstico de inaplicabilidade do regime comum da coisa julgada nos pareça irretocável. Outro ponto de vista, que caminha para definir a coisa julgada coletiva como um instituto autônomo é o exposto por PAUlo RoBerto DE OliveIRA LiMA, que ao analisar a coisa julgada sobre a 
sentença genérica coletiva, chega à conclusão de que não se trata realmente de coisa julgada, na medida em que a decisão do artigo 95 da Lei no 8.078/90 não contém um dispositivo. Ele a define então como "aproveitamento in utilibus do conteúdo do julgado coletivo" $^{478}$, uma categoria autônoma que não é a coisa julgada material. Tese parecida é formulada por ANTONIO GIDI ${ }^{479}$, ao examinar a extensão da coisa julgada à classe substituída. Embora nenhuma dessas manifestações seja conclusiva a respeito, nelas pode se notar o incômodo com a aplicação do conceito da coisa julgada a uma sentença dotada de um grau de abstração tão elevado como a sentença genérica coletiva.

Realmente, a estrutura dessa decisão, que não corresponde àqueles elementos mínimos essenciais do artigo 458 do Código de Processo Civil, impede que o instituto responsável pela articulação entre a sentença coletiva e os processos complementares seja equiparado à coisa julgada, ao menos tal como ela é disciplinada pelo Código nos processos individuais. A eventual aplicação da limitação da indiscutibilidade ao dispositivo (art. 469 do Código de Processo Civil), em particular, acabaria por tornar nula a eficácia externa das questões de mérito resolvidas pela sentença genérica, esvaziando-a de qualquer finalidade prática, na medida em que as sentenças parciais se ressentem da falta de um juízo conclusivo de mérito. Tudo que ela contém são questões prejudiciais, já eliminadas, que exigem a integração da cognição dos elementos faltantes da fattispecie abstrata em processos complementares, para que, somente então, se possa reconhecer o direito à tutela pretendida.

Na realidade, portanto, verificamos que se trata de instituto sui generis, que é regulado de maneira específica pelos artigos 95 e 103, inciso III, do Código de Defesa do Consumidor, e que se afasta da disciplina geral do julgado civil.

Apesar dessa especialidade, e ao contrário do que faz OliveIRA LiMA, consideramos ainda ser adequado denominá-la de "coisa julgada coletiva", por sua afinidade com o modo de operar da coisa julgada. Tal como esta última, também ela

\footnotetext{
478،"Trata-se, como se viu acima, da aplicação in utilibus do julgado coletivo. Não há aqui, é bom que se destaque, coisa julgada oponível a terceiros, até porque não é o dispositivo da sentença prolatada em ação civil pública que resta aplicável aos interessados individuais. Aproveitam-se, sim, os fundamentos fáticos e jurídicos fixados na primeira sentença, as decisões preliminares e prejudiciais, tornando as conclusões a que o magistrado chegou, ao longo da sentença que apreciou a lide coletiva, imutáveis nas lides individuais. Fixadas na lide coletiva a existência dos fatos que ensejaram sua propositura, a responsabilidade do réu e a contrariedade ao Direito, os interessados individuais vitimados somente necessitam de demonstrar essa condição, comprovando a extensão dos danos e liquidando os respectivos valores. Os demais pontos, já resolvidos na lide coletiva, não mais são agitados" (OLIVEIRA LIMA, Paulo Roberto. Contribuição à teoria da coisa julgada. São Paulo: Ed. Revista dos Tribunais, 1997. p. 140, g.n.).

${ }^{479}$ “O que é secundum eventum litis é a extensão in utilibus da coisa julgada para a esfera individual das vítimas do evento.” (GIDI, Antonio. Coisa julgada e litispendência em ações coletivas, cit., p. 140).
} 
consiste essencialmente no vínculo de natureza processual, dirigido a juízes de processos futuros, que os impedem de desconhecer o decidido na sentença genérica sobre os interesses individuais homogêneos. E ela irradiará, em caso de procedência, os efeitos negativo e ativo que são característicos da res judicata, excluindo que os futuros juízes voltem a julgar as questões homogêneas já decididas (imutabilidade), e também os obrigando a tomá-las como pontos firmes ao decidirem as pretensões individuais veiculadas por cada ação complementar de habilitação e liqüidação (indiscutibilidade). Mas não se deve perder de vista que ela tem contornos próprios, muito mais do que na disciplina da extensão subjetiva, naquilo que diz respeito a seu objeto.

Como veremos com mais detalhe nos próximos itens, a Lei ${ }^{\circ}$ 8.078/90 distancia a coisa julgada coletiva do Código de Processo Civil em dois aspectos fundamentais: a) em primeiro lugar, ao fazê-la incidir não sobre o dispositivo, mas sobre as questões prejudiciais relacionadas à "origem comum" genericamente reconhecida na sentença (art. 95); e b) em segundo lugar, ao limitar a indiscutibilidade dessas questões a ações que tenham por objeto "beneficiar as vítimas e seus sucessores" (art. 103, inc. III).

\subsubsection{Questões cobertas pela coisa julgada coletiva}

A grande vantagem que a aplicação da teoria da "coisa julgada parcial sobre o suporte fático" à sentença genérica coletiva proporciona é a circunstância de que com isso não se perde de vista o direito material, a cuja tutela se presta a ação civil coletiva ${ }^{480}$. Postas essas idéias em outras palavras, as questões resolvidas pela sentença de procedência da ação civil coletiva, ao fixarem a responsabilidade do réu, não são tomadas em abstrato, mas sim avaliadas no contexto de uma violação de direitos de toda uma coletividade, com referência a qual surgem diversas pretensões uniformes que são tratadas de maneira concentrada no processo coletivo. A adoção dessa postura permite a plena compatibilização desse atípico processo com os princípios gerais que informam o processo

\footnotetext{
${ }^{480}$ Ao analisar essa teoria, nesse sentido, DOMENICO DALFINO sublinha que “(...) la soluzione di una questione di diritto non può consistere in un mero quesito giuridico, nell'esclusivo e assetico esame della norma, ma deve necessaraimnte rivolgersi all'individuazione della portata della norma in relazione al fatto concretto, in vista della soddisfazione di una determinata situazione sostanziale ritenuta meritevole dall'ordinamento" (Questioni di diritto e giudicato: contributo allo studio dell'ccertamento delle "fattispecie preliminari", cit., p. 226-227).
} 
civil, e permitem também uma visualização mais clara da natureza da decisão contida na sentença genérica.

De fato, na medida em que o objeto da ação coletiva consiste na análise parcial dos elementos do suporte fático de cada direito individual daqueles que foram atingidos pelo ato lesivo, fica evidente que as questões homogêneas tratadas no processo coletivo se constituem como verdadeiros elos, dispostos em uma cadeia de fatos jurídicos aos quais está subordinado o juízo de subsunção do caso concreto à norma jurídica cuja incidência é sustentada pelo autor coletivo. Do ponto de vista lógico, portanto, o juízo de procedência das pretensões individuais depende do reconhecimento de que as questões antecedentes de caráter homogêneo, integrantes do suporte fático comum, sejam julgadas em determinado sentido.

Essas características, como se percebe, são justamente aquelas que definem as questões prejudiciais. O objeto da sentença genérica coletiva é a resolução de questões comuns que, embora não constituam bens jurídicos autônomos, integram o juízo de mérito de cada pretensão individual dos membros da classe, e condicionam o raciocínio a ser desenvolvido nos processos individuais de cumprimento. Facilmente se percebe, portanto, o equívoco em que incorreria o intérprete que pretendesse aplicar o artigo 469 do Código de Processo Civil para determinar o alcance da coisa julgada coletiva, buscando identificar um núcleo "dispositivo" na estrutura de uma sentença que não chega a enunciar o comando de aplicação da lei ao caso concreto. Tal indivíduo somente poderá chegar a resultados artificiais, e potencialmente limitadores do alcance e utilidade da fase coletiva.

Se examinarmos a natureza das questões resolvidas na sentença, e a finalidade a que se destinou essa resolução, de outro lado, concluiremos que a vinculação que a sentença genérica coletiva irradia sobre os processos complementares futuros somente pode ter por objeto questões prejudiciais de contorno homogêneo, porque este é todo o conteúdo da sentença genérica coletiva. Trata-se de decisão que não formula um juízo definitivo sobre o mérito, mas que se limita a resolver questões de que depende esse juízo. Assim, a disciplina dos limites objetivos da coisa julgada coletiva está inteiramente contida no artigo 103, inciso III da Lei $\mathrm{n}^{\mathbf{0}}$ 8.078, que afasta as disposições - materialmente incompatíveis - do Código de Processo Civil nesse campo.

É necessário insistir, contudo, que essa excepcional coisa julgada sobre questões prejudiciais não tem aquela amplitude sobre todos e quaisquer processos futuros da coisa julgada material. A resolução das questões prejudiciais homogêneas vinculará apenas os juízes de processos futuros destinados à decisão do mesmo caso concreto. É necessário 
explicar, nesse sentido, o que deve ser considerado o mesmo caso concreto na ação coletiva.

\subsubsection{O “caso concreto" na ação civil coletiva}

É importante se ter em consideração que o caso concreto, na ação civil coletiva, não consiste na responsabilidade genérica do réu, como poderia dar a entender uma leitura do artigo 95 da Lei $\mathrm{n}^{\mathrm{o}}$ 8.078/90 que fosse inspirada sob a ótica do processo civil tradicional. A pretensão processual deduzida em juízo é a de reparação dos danos individuais, segundo a regra de direito material aplicável à hipótese. Se a primeira sentença não vai a fundo, para analisar todos os elementos do suporte fático necessários à afirmação do direito, isso não muda a circunstância de que a decisão das diversas questões de fato $e$ direito é feita à vista dessa finalidade, que deve ser desde logo enunciada na petição inicial da ação civil coletiva. Não é dada, assim, ao autor coletivo a possibilidade de postular o reconhecimento de responsabilidade civil em abstrato, sem indicar qual a conduta do réu e como ela repercutiu sobre a esfera jurídica dos indivíduos que compõem a classe representada.

Da mesma maneira que ALFREDo BUZAID afirma que a ação de condenação genérica e a ação de liqüidação e constituem relações processuais autônomas, mas ao mesmo tempo, "indissoluvelmente ligadas", em razão da "unidade da lide discutida e

julgada sucessivamente numa pluralidade de relações jurídicas processuais" ${ }^{\text {"481 }}$, pensamos que o complexo constituído pela ação civil coletiva e pelas ações complementares, em regra individuais e subsidiariamente coletiva, também se dedicam à solução de uma única lide, caracterizada por sua projeção coletiva. Os processos que integram esse complexo estão ligados pelo mesmo tipo de vínculo indissolúvel, de maneira que não se pode compreender nenhum deles de forma isolada e abstraída do todo de que fazem parte, e compõem assim um sistema autônomo em cujo interior se manifesta a força da coisa julgada parcial que incide sobre os elementos homogêneos do suporte fático.

No dizer de CÂNDIDO RANGEl DinAmARCo, "a fase de liqüidação da sentença condenatória genérica por lesão a direitos individuais homogêneos se abre em leque, formando-se autos apartados para cada uma das ações individuais, mas todas elas sendo

\footnotetext{
${ }^{481}$ BUZAID, Alfredo. Da liqüidação por artigos em ação de ressarcimento de perdas e danos, cit.
} 
tratadas como continuação do processo em que aquela sentença houver sido produzida” ${ }^{\natural 82}$. A apreensão dessa unidade sistemática das diversas ações em que se decompõe a tutela dos interesses individuais homogêneos é indispensável para o entendimento do modo de operar da coisa julgada coletiva, cujo objeto é extremamente amplo no sentido de alcançar a resolução das questões prejudiciais, mas ao mesmo tempo limitada aos processos que integram o sistema ${ }^{483}$. No interior desse ambiente processual ela assume uma função instrumental, similar àquela que a exigência de coerência interna da fundamentação ${ }^{484}$ desempenha no interior de uma sentença "integral”, e essa é a razão pela qual a sua extensão às questões prejudiciais é facilmente compatibilizada com os princípios gerais da coisa julgada.

O caso concreto discutido na ação coletiva é a lesão de massa, identificada pela causa de pedir ${ }^{485}$, que deve se referir ao fato e ao fundamento jurídico em que se fundam as pretensões uniformes de um grupo ainda indeterminado de indivíduos. A ação coletiva decidirá parcialmente essas pretensões, apenas naquilo que é comum entre elas, sob a forma de questões prejudiciais de que depende o julgamento do mérito de cada uma; a coisa julgada tornará essas questões vinculantes para os juízes de processos futuros que se debrucem sobre as mesmas pretensões. Caso algum indivíduo tenha uma pretensão qualquer contra o réu do processo coletivo, cujos fundamentos não possam ser reduzidos à mesma causa petendi, essa pretensão não comporá a lide coletiva, e os vínculos da coisa julgada coletiva não se farão sentir sobre sua situação individual.

\footnotetext{
${ }^{482}$ DINAMARCO, Cândido Rangel. Instituições de direito processual civil. Instituições de direito processual civil, cit., v. 4, p. 736.

${ }^{483} \mathrm{O}$ mesmo CÂNDIDO RANGEL DINAMARCO também ressalta que a coisa julgada coletiva somente pode operar nos limites do caso concreto de que se tratou na sentença genérica, enfatizando que "a sentença a ser proferida nessa liqüidação ficará contida nos limites da responsabilidade genericamente afirmada na condenação genérica instituída pelo art. 95: não poderá declarar o indivíduo credor por danos diferentes daqueles afirmados nela. Tal é, mutatis mutandis, uma projeção da regra de fidelidade ditada pelo art. 745G do Código de Processo Civil” (As três figuras da liqüidação de sentença, cit., p. 1.397-1.398).

${ }^{484}$ Segundo DINAMARCO, é “indispensável que o relatório, a motivação e o decisório se harmonizem de modo a demonstrar a quem os lê uma coerência interna do próprio ato e, por esse modo, indicar sua fidelidade substancial ao direito. O juiz que relata com clareza os principais acontecimentos do processo e desenvolve fundamentos apoiados nesses elementos e nos preceitos ditados pelo direito, para afinal decidir de acordo com o raciocínio assim desenvolvido, está ao mesmo tempo dando demonstração de seriedade e favorecendo o exame crítico da própria sentença pelas partes e pelos tribunais" (Instituições de direito processual civil, cit., v. 3, p. 687). A coerência interna da fundamentação é tutelada pelo direito positivo pelo recurso de embargos de declaração, previsto pelo artigo 535 do Código de Processo Civil, que permite às partes requererem do próprio juiz a eliminação dos vícios de contradição, obscuridade ou omissão.

${ }^{485} \mathrm{~A}$ importância da causa de pedir na determinação do objeto da ação civil coletiva é posta em destaque por JOSÉ MARCELO DE MENEZES VIGLIAR (Interesses individuais homogêneos e seus aspectos polêmicos, cit., passim; A causa de pedir e os interesses individuais homogêneos, cit.).
} 


\subsection{Aplicações}

\subsubsection{Estabelecimento genérico de padrões de liqüidação em direitos individuais homogêneos}

A mais importante aplicação prática desse modo de compreender a coisa julgada sobre a sentença genérica coletiva está na determinação do alcance da expressão "fixação a responsabilidade do réu" (art. 95, da Lei ${ }^{\circ}$ 8.078/90), que constitui o próprio objeto do processo coletivo. Segundo o que vimos até aqui, pelo fato de incidir sobre uma sentença parcial, a coisa julgada coletiva se caracteriza por tornar indiscutíveis as questões prejudiciais ali resolvidas em âmbito extraprocessual, limitado aos processos voltados à aplicação do direito no mesmo caso concreto (que é a reparação do dano de massa). Tratase assim de uma coisa julgada parcial sobre o suporte fático, segundo a teorização proposta por VitTORIO DENTI, e por nós aceita. Assim como a coisa julgada tradicional, ela se caracteriza pela finalidade prática, mas enquanto nesta se busca a estabilidade do processo em todas e quaisquer demandas futuras em que o mesmo bem da vida seja discutido, naquela se busca assegurar uma estabilidade instrumental no complexo de processos complementares destinados a aferir os aspectos heterogêneos, que são tipicamente a titularidade e a extensão dos danos individuais.

A hipótese que nos propomos a analisar é a de que a estrutura da coisa julgada parcial sobre a porção coletiva do suporte fático permita o estabelecimento genérico de padrões de liqüidação dos direitos individuais homogêneos, ou mesmo uma liqüidação prévia das obrigações individuais. Essa é uma possibilidade a priori permitida pela lei, pois o texto do artigo 95 do da Lei $n^{\circ} 8.078 / 90$ se limita a afirmar que em caso de procedência o juiz fixará a responsabilidade do réu, sem de um lado restringir em que termos deverá ser feita essa "fixação"; mas, contudo, sem autorizar explicitamente o juiz a avançar em questões relacionadas à quantificação dos danos individuais, quando eles forem um dado homogêneo da lide coletiva.

O direito projetado quis resolver essa dúvida. Visando a assegurar um maior proveito útil da sentença genérica coletiva, o Projeto de Lei $n^{\circ}$ 5.139/09 trazia em seu artigo $27, \S 3^{\circ}$, a previsão de que "na sentença condenatória à reparação pelos danos individualmente sofridos, sempre que possível, o juiz fixará o valor da indenização individual devida a cada membro do grupo ou um valor mínimo para a reparação do dano". 
Já o $\S 4^{\circ}$ previa que "quando o valor dos danos individuais sofridos pelos membros do grupo forem uniformes, prevalecentemente (sic) uniformes ou puderem ser reduzidos a uma fórmula matemática, a sentença do processo coletivo indicará esses valores, ou a fórmula de cálculo da indenização individual e determinará que o réu promova, no prazo que fixar, o pagamento do valor respectivo a cada um dos membros do grupo". Como esse Projeto foi rejeitado pela Comissão e Constituição e Justiça da Câmara dos Deputados, o que tornou bastante incerta a sua aprovação, iremos examinar a questão sob o direito vigente. E nesse sentido, nos parece que é justamente na estrutura da coisa julgada sobre a sentença genérica coletiva, tomada em consideração como elemento de ligação estrutural entre a ação coletiva e as ações complementares, que podemos encontrar a resposta sobre a possibilidade de estabelecimento prévio dos parâmetros de liqüidação dos créditos individuais.

É sabido que grande parte da doutrina defende que a sentença coletiva não pode, em nenhuma hipótese, analisar questões relacionadas à liqüidação do dano. Trata-se de uma concepção de divisão da atividade cognitiva em um ponto fixo e monolítico, de modo que caberia ao juiz da fase coletiva "declarar" a fixação de responsabilidade do réu e nada mais, sendo-lhe absolutamente vedado conhecer de questões relacionadas à liqüidação do dano. Nesse sentido, escrevem PAtrícia Pizzol MirandA ${ }^{486}$, GuAdaluPe Louro Turos Couto $^{487}$, luiz Paulo da Silva Araújo Filho ${ }^{488}$, Aluisio Gonçalves de Castro MENDES $^{489}$, CAMILO ZuFELATO ${ }^{490}$, entre outros.

\footnotetext{
486“'De outro lado, se se tratar de ação de responsabilidade civil por dano a direito individual homogêneo, a liqüidação será sempre necessária e deverá ser realizada sob a modalidade de artigos, conforme veremos a seguir" (PIZZOL, Patrícia Miranda. Liqüidação nas ações coletivas, cit., p. 183, g.n.).

${ }^{487}$ A autora atribui, contudo, a essa (suposta) vedação o motivo de ter se revelado o procedimento especial "inoperante" para a missão de facilitar o acesso à Justiça (COUTO, Guadalupe Louro Turos. A efetividade da liqüidação e da execução da tutela jurisdicional coletiva na área trabalhista e o Código Brasileiro de Processos Coletivos. In: GRINOVER, Ada Pellegrini, MENDES, Aluisio Gonçalves de Castro; WATANABE, Kazuo (Orgs.). Direito processual coletivo e o anteprojeto de Código Brasileiro de Processos Coletivos. São Paulo: Ed. Revista dos Tribunais, 2007. p. 303).

${ }^{488}$ ARAÚJO FILHO, Luiz Paulo da Silva. Ações coletivas: a tutela jurisdicional dos direitos individuais homogêneos, cit., p. 196-197.

${ }^{489} \mathrm{O}$ professor da Universidade Estadual do Rio de Janeiro, contudo, escreve com uma postura bastante crítica frente a esse modelo, defendendo a alteração da lei. Sustenta ele, em relação ao art. 95 da Lei no 8.078/90, que "o texto legal, relacionado com os interesses individuais homogêneos, parece ter se equivocado duplamente. Primeiro, como supra mencionado, por fazer menção tão-somente às obrigações de pagar quantia certa. Segundo, por supor um modelo monolítico, baseado sempre em uma sentença genérica, fixadora apenas da responsabilidade do réu pelos danos causados que, para se materializar, precisaria necessariamente da consecução de etapas posteriores de liqüidação, com a identificação das vítimas, dos respectivos danos e do quantum debeatur, e execução, nos termos do art. 97 do Cód. de Defesa do Consumidor. (...) Porém, nem sempre haverá a ausência de determinação dos beneficiários da sentença e liquidez da condenação." (MENDES, Aluisio Gonçalves de Castro. Ações coletivas no direito comparado e nacional, cit.,p. 288-289).

${ }^{490}$ Ressalve-se aqui que tal posicionamento não é expressamente formulado, devendo-se a conclusão de que referido autor considera inviável a liquidação prévia dos danos na fase coletiva à afirmação de que a
} 
Em nosso entendimento, essa interpretação decorre de uma má compreensão das peculiaridades da coisa julgada coletiva, e particularmente da tentativa de se aplicar a disciplina da coisa julgada ordinária sem as adaptações exigidas pela natureza parcial da sentença genérica. De fato, a coisa julgada coletiva é o elemento de articulação estrutural entre os diversos processos em que se desdobra à resolução da lide coletiva. Uma aplicação restritiva de sua disciplina irá tolher o resultado útil do processo, impedindo que a fase coletiva do procedimento dê tratamento uniforme e molecularizado a todas as questões que permitam esse tipo de análise em razão de suas características uniformes.

Particularmente, a sentença genérica coletiva é tratada como sentença declaratória da "fixação de responsabilidade", e assim se restringe a obrigatoriedade do decidido em processos futuros ao "dispositivo" consistente nessa declaração. Busca-se, assim, aplicar o artigo 469 do Código de Processo Civil para restringir a coisa julgada a um ponto que, em si mesmo, significa muito pouco e não encontra correspondência com qualquer categoria jurídica de direito material conhecida. Analiticamente, há dois vícios de extrema gravidade nesse raciocínio: a) em primeiro lugar, a "fixação de responsabilidade", por não se constituir em uma relação jurídica, não é passível de tutela jurídica autônoma e não pode ser objeto de uma declaração que vincule o comportamento das partes para fora do processo; b) como a sentença genérica coletiva também não se manifesta de maneira conclusiva sobre a procedência do direito, com a emissão de uma manifestação de vontade, a ela falta um dispositivo completo que pudesse receber isoladamente a proteção da coisa julgada material segundo a disciplina do Código de 1973.

Os limites objetivos da coisa julgada sobre a sentença genérica coletiva devem ser buscados na fórmula mais fluída no artigo 103, inciso III, da Lei $\mathrm{n}^{\circ}$ 8.078/90, dispositivo este que, em razão de sua incompatibilidade com o sistema do processo comum, cuja sentença é estruturalmente diversa em seus elementos essenciais, ab-roga a incidência do art. 469 nos processos coletivos. A coisa julgada parcial, portanto, ao exercer o efeito de "beneficiar as vítimas e seus sucessores", estende-se necessariamente sobre as questões integrantes do suporte fático - questões prejudiciais, portanto - resolvidas na sentença genérica coletiva de procedência. Essa maior amplitude é compensada por um âmbito de aplicação mais restrito, que é confinado aos processos em que se discute a mesma lesão de projeção coletiva.

disciplina do Projeto de Lei n n $^{2} 139 / 09$ representa uma "sensível alteração" em relação ao modelo do Código de Defesa do Consumidor (ZUFELATO, Camilo. Coisa julgada coletiva, cit., p. 69). 
Dessa forma, o juiz do processo coletivo não apenas pode como deve estabelecer os padrões a serem seguidos na liqüidação dos danos individuais, até onde for possível dar tratamento homogêneo a essa questão ${ }^{491}$. Nesse exato sentido, REMO CAPONI defende que a coisa julgada nas ações coletivas, voltadas à tutela de direitos individuais homogêneos na forma ressarcitória, deve ter um objeto variável e determinado pelo juízo no caso concreto, a depender da relação entre as questões comuns e as questões individuais pertinentes ao reconhecimento de cada crédito específico; tratar-se-ia de uma coisa julgada dimensionada pela porção de questões comuns a serem tratadas na ação coletiva ${ }^{492}$. Essa proposta, em nosso entendimento, vai ao encontro da disciplina que os artigos 95 e 103, inciso III da Lei $\mathrm{n}^{\circ} 8.078 / 90$ conferem à coisa julgada sobre a sentença genérica coletiva do processo civil brasileiro.

Nesse sentido, a adoção, na prática judiciária, da prévia determinação em concreto da porção homogênea da lide coletiva, para fins de dimensionamento do objeto do processo e da coisa julgada coletiva, é medida que tem o potencial para aperfeiçoar em muito a eficiência do procedimento especial. Isto é particularmente verdadeiro em casos

\footnotetext{
${ }^{491}$ ÉRICA BARBOSA E SILVA preconiza essa solução como a mais adequada, embora não esteja claro se ela a considera possível sob o direito positivo vigente. Afirma ela que "indica-se, de lege ferenda, que o magistrado, ao proferir uma sentença genérica em defesa de direitos individuais homogêneos, esclareça não só a responsabilidade pela reparação do dano e o dever de indenizar, mas também indique a maior quantidade possível de elementos da obrigação, tornando, se possível, desnecessária a liqüidação" (Cumprimento de sentença em ações coletivas. São Paulo: Atlas, 2009. p. 116; em passagem em que se mantém a mesma dubiedade, em co-autoria com PAULO HENRIQUE DOS SANTOS LUCON, Análise crítica da liqüidação e execução na tutela coletiva. In: LUCON, Paulo Henrique dos Santos (Coord.). Tutela coletiva: 20 anos da lei da ação civil pública e do fundo de direitos difusos. 15 anos do Código de Defesa do consumidor. São Paulo: Atlas, 2006., p. 177). Na doutrina italiana, em estudo sobre a azione collettiva risarcitoria, CLAUDIO CONSOLO defende que a condenação genérica deve ser "reforçada", de modo que o juiz não pode se limitar a afirmar uma responsabilidade em abstrato, devendo antes "già delineare nel modo più preciso e circonstanziato possibile i criteri che ne dovvrano guidare la sucessiva liquidazione" (CONSOLO, Claudio; BONA, Marco; BUZZELLI, Paolo. Obiettivo class action: l'azione colletiva risarcitoria, cit., p. 215).

${ }^{492}$ Segundo CAPONI, "il giudicato può avere un oggetto variabile e giudizialmente determinabile in concreto, in dipendenza della distinzione tra questioni comuni e questioni individuali ai fini dell'accertamento dei singoli crediti risarcitori. Anche tale distinzione, dà dimensione al giudicato. Tale dimensionamento non è che uno dei tanti riflessi dell'applicazione del canone di proporzionalità nell'impiego delle risorse giudiziali, che suggerisce di configurare la disciplina delle cause seriali di massa all'esito di un bilanciamento di valori, che colloca su un piatto della bilancia gli elementi che sorreggono il modello tradizionale di tutela giurisdizionale dei diritti nel singolo processo (in particolare, contraddittorio, effettività della tutela, giudicato), e sull'altro piatto l'efficienza dell'amministrazione della giustizia, che sorregge la tutela giurisdizionale dei diritti nell'insieme dei processi o in una classe di essi." (Il giudicato civile dimensionato, cit., p. 954) Essa mesma visão da possibilidade de variação no conteúdo da sentença genérica coletiva é sugerida por CÂNDIDO RANGEL DINAMARCO, ao afirmar - tratando desse "especialíssima" liqüidação de sentença - que "no tocante a essa regra de fidelidade da liqüidação à sentença liquiidanda é pertinente a seguinte equação: a) quanto mais elementos da obrigação a sentença condenatória genérica contiver, menos espaço sobra para investigação no processo liqüidatório; b) quanto mais elementos faltarem, mais espaço haverá e, portanto, mais amplos deverão ser a instrução e os debates." (As três figuras da liqüidação de sentença, cit., p. 1.398-1.399).
} 
nos quais a liqüidação do dano individual ainda é muito trabalhosa ou dispendiosa, ou nos quais a liqüidação dependa de arbitramento pelo juiz.

\subsubsection{Complexidade da prova do valor individual do dano}

A importância prática da aplicação proposta parece evidente em casos em que existir grande complexidade, ou grandes custos associados à prova necessária para a liqüidação do dano causado a cada indivíduo que compõe a classe. Nessas circunstâncias, a imposição do ônus de promover todas as provas necessárias à liqüidação a cada um dos indivíduos que integrem a classe pode impedir que suas pretensões individuais sejam efetivamente levadas a juízo, especialmente se o valor dos créditos individuais for menor do que os custos de perícia. Como foi observado por ADA PELLEGRINI GRINOVER, "não se poderá dar preferência aos processos coletivos, se estes não se revestirem de eficácia, no mínimo, igual à que pode ser alcançada em processos individuais. Se uma sentença coletiva não servir para facilitar o acesso à justiça, se os indivíduos forem obrigados a exercer, num processo de liqüidação, as mesmas atividades processuais que teriam que desenvolver numa ação condenatória de caráter individual, o provimento jurisdicional terá sido inútil e ineficaz, não representando qualquer ganho para o povo"493.

Um exemplo claro dessa situação pode ser encontrado em ações coletivas que discutam a adoção de práticas de fornecedores que fraudem a livre concorrência, associando-se em cartéis para fixar preços ou distribuir entre si mercados, determinando assim de forma arbitrária os preços a serem oferecidos aos consumidores (artigo 20, incisos I e III da Lei $n^{\circ}$ 8.884/94). Em uma situação tal, a determinação do valor que os participantes do cartel obtiveram com a fixação arbitrária dos preços praticados no mercado dependerá de complexas perícias contábeis e econômicas, por vezes complementares, destinadas a avaliar qual seria o preço justo do bem de acordo com as leis de mercado e qual foi o proveito obtido por cada unidade comercializada.

Nessa hipótese, a barreira econômica para o acesso à justiça do direito à recomposição individual do dano se localizará no momento da liqüidação do dano, pois a prova do valor do prejuízo individualmente sofrido por efeito da conduta ilícita é mais

\footnotetext{
${ }^{493}$ GRINOVER, Ada Pellegrini. Da class action for damages à ação de classe brasileira: os requisitos de admissibilidade, cit., p. 14.
} 
dispendiosa do que o potencial efeito patrimonial individual que dela possa decorrer. Entretanto, se for possível estabelecer um padrão de liqüidação aplicável a toda a classe isto é, se também a quantificação do dano for um aspecto homogêneo da lide, passível de tratamento coletivo - o caráter móvel e fluído da coisa julgada coletiva não só deixa de impedir, como recomenda que essa questão comum atinente à liqüidação seja resolvida de maneira concentrada, e que a conclusão a que se chegue a respeito seja observada como ponto prejudicial indiscutível em todas as ações complementares de habilitação e liqüidação individual. Assim, prosseguindo em nosso exemplo, no contexto de um cartel que elevou artificialmente os preços de eletrodomésticos, a sentença coletiva pode desde logo determinar o valor de sobrepreço cobrado em cada unidade, restando ao consumidor apenas o ônus de comprovar quantas unidades do produto foram por ele adquiridas em sua ação de cumprimento.

É bem verdade que, se a sentença coletiva se limitasse a declarar uma abstrata responsabilidade genérica do réu, essa mesma liqüidação poderia ser promovida de forma coletiva, na forma do artigo 100 do Código de Defesa do Consumidor, e destinada integralmente ao fundo de recomposição dos bens lesados. Haverá algumas oportunidades em que o consumidor dificilmente conseguirá provar até mesmo qual foi a quantia individualmente consumida do produto, e não haverá alternativa que não a execução coletiva: pense-se nos cartéis que alteram os preços de combustíveis. Mas há hipóteses em que, determinado o valor de lucro artificialmente obtido por unidade, a ser utilizado como padrão predefinido para liqüidação para toda a classe, o consumidor tem plenas condições de fazer a prova de seu dano individual: é o que ocorre em cartéis que tenham por objeto bens duráveis de consumo, cujas notas fiscais normalmente são conservadas pelos seus adquirentes (eletrônicos, eletrodomésticos, automóveis), ou serviços em que as relações entre fornecedor e consumidor sejam escrituradas contabilmente (tarifas de serviços públicos, taxas de juros em contratos de crédito, etc.). Nessas situações, a remissão à liqüidação coletiva sacrificaria desnecessariamente os direitos dos indivíduos que foram efetivamente prejudicados com a conduta que violou a livre concorrência. Não há porque se contentar com a recomposição residual do dano causado, quando o processo pode viabilizar a sua recomposição específica. A fixação de responsabilidade do artigo 95 do Código de Defesa do Consumidor, assim, deve abranger os termos em que o réu é responsável, adentrando as questões da quantificação do dano até onde elas sejam homogêneas. 


\subsubsection{Conteúdo da obrigação deve obrigatoriamente ser arbitrado}

Os parâmetros para a liqüidação individual podem ser estabelecidos de forma genérica não apenas em razão da dificuldade da prova, mas também em casos em que já se saiba, desde o momento da propositura da demanda, que o conteúdo da obrigação tenha de ser arbitrado pelo juiz, segundo critérios equitativos. Nessa situação, o benefício que a aplicação da característica de maleabilidade e fluidez da coisa julgada coletiva proporciona é o de assegurar uniformidade às liquidações individuais, pois essa característica não representa obstáculo de acesso à Justiça nas ações individuais complementares.

Nos termos do artigo 475-C, inciso II, do Código de Processo Civil, dentre outras hipóteses a liqüidação será efetivada por arbitramento quando isso "resultar da natureza da obrigação". Particularmente no direito do consumidor, o arbitramento é a única forma pela qual se pode determinar o conteúdo de obrigações como a redução proporcional do preço em caso de vício de qualidade ou de quantidade do produto ou do serviço (art. 18, inc. III; art. 19, inc. I; art. 20, inc. III, todos do Código de Defesa do Consumidor). Esse arbitramento é feito a partir de dados que podem ser aferidos genericamente, tais como a natureza do defeito ou da má informação difundida na publicidade do produto e a correspondente depreciação por elas causada, de modo que não há circunstâncias particulares aos indivíduos lesados que tenham de ser necessariamente averiguadas nas ações complementares individuais. Trata-se de hipótese em que o valor do dano é um dos elementos do suporte fático comum que é compartilhado por toda a classe, ou seja, o valor do dano está compreendido no núcleo de homogeneidade da lide coletiva.

Por exemplo, tome-se a hipótese de que um fabricante de automóveis anuncie por meios de comunicação de massa que seu produto contém uma determinada característica tecnológica, que na realidade não foi ainda incorporada nos modelos efetivamente comercializados. Esses bens são vendidos por preços ligeiramente acima da média de mercado para modelos equivalentes, mas ainda assim são massivamente adquiridos nessas condições em razão da legítima expectativa de consistirem em produto de classe superior. Em casos tais, a liqüidação por arbitramento do valor do abatimento proporcional do preço, a que fará jus cada adquirente do produto ou serviço, pode muito bem ser feito na própria sentença genérica coletiva. Essa providência não apenas eliminará essa questão antecipadamente da matéria a ser conhecida nas ações individuais, contribuindo para a mais rápida solução do litígio, como também proporcionará uma tutela de conteúdo 
isonômico para todos os substituídos que foram atingidos - em igual medida - pelo ato do fornecedor.

Além dessa hipótese, LUIZ RODRIGUES WAMBIER menciona a hipótese de conversão do dano ambiental em indenização pecuniária, por impossibilidade da tutela específica ${ }^{494}$; e de fato, o arbitramento é solução adequada para diversas outras hipóteses em que, perecendo bem que não admite avaliação econômica segundo as regras do comércio, se faça necessária a conversão da obrigação específica em perdas e danos.

As finalidades da tutela coletiva de direitos individuais não se limitam à aceleração e economia do procedimento, mas compreendem também a uniformidade de decisões sobre relações jurídicas que são essencialmente idênticas. Dessa forma, sempre que a definição do quantum debeatur tiver de ser feita por arbitramento judicial, em verdadeira sentença determinativa, e desde que não importem para essa determinação as circunstâncias individuais da vítima, é recomendável que o juiz faça esse arbitramento na própria sentença coletiva.

\subsubsection{Importância da fixação do objeto litigioso na ação civil coletiva}

A se admitir as aplicações que estamos a propor neste trabalho, o processamento da ação civil coletiva exigiria maiores cuidados do que os que normalmente lhe são dispensados, principalmente na fase das "providências preliminares", em que cabe ao juiz fixar os pontos controvertidos e determinar as provas a serem produzidas (art. $331, \S 2^{\circ}$, do Código de Processo Civil). Como o objeto da fase coletiva não é determinado, podendo variar de acordo com a extensão do núcleo de questões comuns que se faça presente no caso concreto examinado, é necessário que em um momento inicial do processo o juiz decida quais serão as questões que receberão tratamento uniforme no âmbito da ação coletiva.

\footnotetext{
494،Há situações, no entanto, em que embora demonstrado o dano, será difícil ou até mesmo impossível a sua quantificação exata, hipótese em que a Proposta ora analisada sugere que se empregue o arbitramento (cf. art. $\left.25, \S 1 .^{\circ}\right)$. Tal circunstância pode ocorrer, por exemplo, no caso em que tenha havido danos ao meioambiente, em que se mostre impossível a reparação específica. No caso de eliminação de grande quantidade de animais, por exemplo, o valor da indenização será fixado por arbitramento, mesmo porque não haveria condições, em semelhantes circunstâncias, de se atribuir um valor pecuniário a cada um dos animais atingidos pelo ato ilícito." (WAMBIER, Luiz Rodrigues. Considerações sobre a liqüidação de sentença coletiva na proposta do Código-modelo de processo coletivo para a Ibero-América. Revista de Processo, São Paulo, n. 121, p. 149-168, jul./ago. 2004).
} 
Desde que se reconheça que a ação civil coletiva terá por objeto questões prejudiciais às pretensões individuais, cuja quantidade poderá variar a depender da homogeneidade no caso concreto, torna-se imprescindível que, ainda na fase preliminar do processo, seja feito um aprofundado exame da admissibilidade da ação coletiva - ou seja, que se verifique se os direitos tutelados se encaixam no conceito processual de homogeneidade que constitui uma das condições específicas do interesse na ação civil coletiva - e que seja delimitado o campo do contraditório que será reservado a cada uma das fases, coletiva e complementar, em que se divide o procedimento.

Em outras palavras, sendo fluído e variável o objeto do processo coletivo, a depender da extensão das questões comuns, é indispensável para a adequada formação do contraditório que seja dado às partes desde logo conhecer quais os pontos a que circunscreverá o objeto do processo, tanto no sentido de lhes proporcionar o direito de recurso no que diz respeito à adequação do procedimento para tratar as questões que constituirão seu objeto de modo uniforme, como no de viabilizar o seu amplo direito de defesa no curso da ação coletiva, evitando-se assim que sejam elas colhidas de surpresa em seus esforços probatórios, por terem julgado que essa ou aquela questão ficaria reservada para as ações complementares. Esses interesses, é de importância registrar, são comuns ao autor e ao réu: a concentração de questões heterogêneas na ação civil coletiva, naquele fenômeno do processo pseudocoletivo a que aludiu LUIZ PAULO ARAúJO DA SILVA FILHO $^{495}$, pode tanto embaraçar o desenvolvimento da ação coletiva, comprometendo os esforços do autor coletivo em obter a tutela eficaz da classe, como pode também resultar no comprometimento de defesa do réu. Em outros termos, a surpresa processual quanto ao objeto do processo pode conduzir à indevida improcedência do pedido, tanto por não ter se preparado o autor coletivo para demonstrar determinada questão ainda na fase coletiva; como pode também conduzir a injustiças contra o réu, pelo mesmo motivo.

Nesse sentido, a análise inicial da admissibilidade da ação civil coletiva tende a convergir para o modelo procedimental da class action norte-americana, em que o processo passa por um filtro inicial conhecido como certification, dedicado a decidir de forma detalhada e minuciosa sobre a admissibilidade do processamento coletivo da ação, bem como sobre a conveniência e oportunidade de instituir o separate trial no processamento da demanda. A propósito, a necessidade dessa convergência foi sustentada

\footnotetext{
${ }^{495}$ ARAÚJO FILHO, Luiz Paulo da Silva. Ações coletivas: a tutela jurisdicional dos direitos individuais homogêneos, cit., p. 199-202.
} 
por SWARAi CERVONE DE Oliveira, em monografia acerca do papel do juiz nas ações coletivas brasileiras $^{496}$.

De fato, a complexidade das questões envolvidas em um processo voltado à tutela coletiva dos interesses de todos os membros de uma classe, exige do juiz uma postura ativa no sentido de moldar o procedimento, sob pena de este se tornar inviável ou propiciar a violação dos direitos processuais das partes e terceiros. Como assinala VIGORITTI ${ }^{497}$, tratase aqui da chamada defining function do juiz nas ações coletivas, consistente em um poderdever de exigir das partes a definição mais precisa dos contornos da classe representada e da homogeneidade dos interesses a serem discutidos no processo. E na linha do que ABRAHAM CHAYES prega a respeito do papel dos juízes no processo de interesse coletivo, nisso o magistrado deve assumir um papel ativo, responsabilizando-se por organizar e moldar o procedimento de forma que este seja viável e capaz de proporcionar resultados justos $^{498}$.

\subsubsection{Exclusão da coisa julgada erga omnes em demandas conexas ao caso concreto decidido na ação coletiva}

Desde que a coisa julgada na ação coletiva tem eficácia erga omnes, e que seu objeto é o reconhecimento de responsabilidade do réu por determinada obrigação, surge o problema de se determinar em que medida esse reconhecimento pode ser aproveitado como ponto prejudicial firme, em outras demandas conexas à situação homogênea discutida na ação coletiva, mas que com ela não se confundem. Em outras palavras, é necessário estabelecer se as questões prejudiciais resolvidas na sentença genérica coletiva aproveitam de fato a todos, como induz a pensar a locução "erga omnes", ou se na realidade ela é mais restrita do que isso.

\footnotetext{
${ }^{496}$ Conforme explica o autor, de acordo com técnica processual brasileira a decisão de certification é feita a partir do conceito de interesse processual. "Cuida-se, portanto, de verificar a prevalência das questões de fato que tornam os interesses protegidos homogêneos e a superioridade da tutela coletiva em relação à individual. À míngua de previsão legal expressa a respeito da certificação, o juiz poderá exercer o controle da condição da ação consistente no interesse de agir, nas modalidades adequação e utilidade" (OLIVEIRA, Swarai Cervone. Poderes do juiz nas ações coletivas. São Paulo: Atlas, 2009. p. 81).

${ }^{497}$ VIGORITI, Vincenzo. Interessi collettivi e processo: la legittimazione ad agire. Milano: Giuffrè, 1979. p. 269.

498، The judge is not passive, his function limited to analysis and statement of governing legal rules; he is active, with responsibility not only for credible fact evaluation but for organizing and shaping the litigation to ensure a just and viable outcome" (CHAYES, Abraham. The role of the judge in public law litigation. Harvard Law Review, v. 89, p. 1302, May 1976).
} 
Por tudo o que se viu até este ponto, somos levados a responder com naturalidade que não são todos e quaisquer interessados que podem se beneficiar das questões resolvidas pela sentença genérica coletiva ${ }^{499}$. É necessário atentar para o fato de que o artigo 103, inciso III, da Lei no 8.078/90 dispõe que a coisa julgada irá operar apenas "para beneficiar todas as vítimas e seus sucessores". Como se vê, a res judicata não proporciona uma eficácia declaratória geral sobre as questões resolvidas pela sentença, mas, pelo contrário, vincula a sua obrigatoriedade aos processos individuais a serem movidos por vítimas e sucessores. Mantém-se o princípio da coisa julgada parcial, que é o de nada obstante transcender os limites de um processo, jamais ultrapassar os confins da lide julgada em sucessivas demandas complementares. Portanto, a qualidade de vítimas e sucessores, que são os únicos indivíduos aptos a se beneficiarem da coisa julgada coletiva, se determina pelo objeto da ação coletiva, isto é, pela pretensão comum que é identificada pela coincidência da parcela homogênea da causa de pedir a que se vincula a pretensão de tutela final deduzida na petição inicial da ação civil coletiva.

Por isso, a coisa julgada coletiva mantém estrita vinculação com a causa de pedir comum à classe, como elemento revelador do caso concreto deduzido em juízo, sendo que fora de seus limites ela não irradiará qualquer efeito, mesmo quando houver afinidade ou conexão entre a situação do indivíduo externo ao grupo e a coletividade substituída em juízo.

O exemplo típico de aplicação dessa hipótese de exclusão da coisa julgada pode ser encontrado, também, nas ações coletivas em prol do consumidor. Como se sabe, a legislação do consumo proporciona uma disciplina de proteção bastante intensa, se comparada ao direito civil e comercial, em razão da presumida vulnerabilidade do consumidor diante dos fornecedores. Ocorre que nem todos os que vêm a adquirir os produtos oferecidos no mercado de consumo se encontram nessa situação de desvantagem no momento da aquisição do bem ou serviço, razão pela qual não são todos eles que poderão se beneficiar de uma causa de pedir comum fundada no Código de Defesa do Consumidor.

Tome-se como exemplo uma empresa que venha a adquirir uma grande quantidade de computadores para equipar seus escritórios, negociando diretamente com os fabricantes e estando em condições de obter detalhes sobre os componentes utilizados em cada

\footnotetext{
${ }^{499}$ Nesse sentido, TEORI ZAVASCKI escreve que "os beneficiados pela sentença de procedência serão os abrangidos no âmbito da substituição processual. É importante, para esse efeito, considerar o disposto no art. $2^{\circ}$-A da Lei 9.494, de 10.09.1997: 'A sentença civil prolatada em ação de caráter coletivo proposta por entidade associativa, na defesa dos interesses e direitos dos seus associados, abrangerá apenas os substituídos que tenham, na data da propositura da ação, domicílio no âmbito da competência territorial do órgão prolator"” (Processo coletivo: tutela de direitos coletivos e tutela coletiva de direitos, cit., p. 176).
} 
unidade. Essa empresa não se encontra, claramente, na mesma condição que o adquirente médio individual, cuja única fonte de informação é a mensagem publicitária. Por isso, ela não desfrutará da proteção especial do Código de Defesa do Consumidor no que diz respeito à disciplina do vício de qualidade pela disparidade com o constante da oferta publicitária, e terá de buscar proteção para eventual pretensão contra a empresa nas regras de responsabilidade pelo vício oculto do direito civil. Assim sendo, pode se dizer que embora a empresa tenha adquirido o mesmo produto, ela não integra a classe de consumidores substituída em juízo na ação coletiva movida com a finalidade de fixar a responsabilidade genérica do fornecedor pelo vício do produto, e não estará habilitada a promover ação complementar de liqüidação com base nesse julgado ${ }^{500}$.

Embora essa limitação pareça dizer respeito aos limites subjetivos da coisa julgada coletiva, na realidade ela decorre dos limites objetivos do caso concreto que foi julgado: a lesão de massa praticada contra os consumidores, passível de subsunção à regra de responsabilidade por vícios de qualidade do Código do Consumidor ${ }^{501}$. A eficácia dessa coisa julgada sobre questões prejudiciais, por sua amplitude, somente pode operar dentro dos limites de causas que compartilhem a mesma causa de pedir comum que foi considerada na sentença genérica, de modo que o objeto do julgado fica restrito à classe representada na ação coletiva. Se não fosse assim, a resolução das questões prejudiciais comuns, que compõem o objeto da coisa julgada coletiva, perderia o seu caráter instrumental à decisão de um caso concreto, e acabaria por se desviar dos princípios gerais

\footnotetext{
${ }^{500}$ Com conclusões no mesmo sentido da que é aqui apresentada, ANTONIO GIDI afirma que o indivíduo que não se enquadra no conceito de consumidor somente poderia se beneficiar da sentença genérica coletiva caso houvesse coincidência entre a norma de direito civil e a regra especial de direito do consumidor: "Isso significa que há diversidade no próprio direito material a ser tutelado em cada situação, conduzindo à necessidade de ações diferentes para protegê-los. Todavia, nos casos em que há identidade ou semelhança de causa de pedir, vale dizer, em que o direito material das relações de consumo e o direito civil comum prescrevem a mesma norma, ainda aqueles que não estão envolvidos em uma relação de consumo devem ser beneficiados" (Coisa julgada e litispendência em ações coletivas, cit., p. 141). Para isso, entretanto, nos parece que seria indispensável que a regra de direito civil houvesse também sido apresentada como fundamento da demanda coletiva, e que a decisão houvesse sido dada com essa regra em consideração, sob pena de se ultrapassarem os limites objetivos da coisa julgada coletiva. No mesmo sentido, LUIZ PAULO DA SILVA ARAÚJO FILHO enquadra a questão sob o enfoque da necessidade de comprovar "a pertinência da causa de pedir", dando o exemplo de filiado a sindicato que pretenda se habilitar a sentença que reconheceu a obrigação da concessão de determinado reajuste a servidores públicos, quando este, em contraste com outros membros da classe, ingressou no serviço público após a revogação na norma em que se fundava o direito (Ações coletivas: a tutela jurisdicional dos direitos individuais homogêneos, cit., p. 196).

${ }^{501}$ RICARDO DE BARROS LEONEL, precisamente, afirma que "na liqüidação da sentença condenatória sobre interesses individuais homogêneos, a complexidade não é subjetiva, mas objetiva (...) há necessidade de comprovar não só o quantum debeatur ao lesado, mas, além disso, a ocorrência do dano individual e seu nexo causal com a conduta reconhecida na sentença, i.e., se o liquidante se insere na coletividade lesada pela conduta reconhecida na decisão" (Manual do processo coletivo, cit., p. 385).
} 
da teoria da coisa julgada, gerando resultados imprevisíveis e potencialmente violadores do devido processo legal.

Essa limitação das questões decididas ao caso concreto de lesão coletiva também exerce o efeito de tutelar o réu, condenado a indenizar a classe, em suas relações de regresso frente a outras pessoas, sejam indivíduos ou outras organizações. $\mathrm{O}$ reconhecimento de responsabilidade genérica é eficaz somente em relação à classe substituída em juízo ("vítimas e sucessores”, na dicção do art. 103, inciso III do CDC), de modo que a coisa julgada coletiva não inibe o exercício de ações de regresso contra outras empresas inseridas na mesma cadeia produtiva, e nem as questões resolvidas se aplicam em contextos outros que não o da relação específica discutida na ação civil coletiva. Assim, por exemplo, o reconhecimento de negligência do fornecedor como questão capaz de fixar sua responsabilidade frente à classe (art. 95, da Lei $n^{\circ}$ 8.078/90) não vincula o juiz de uma eventual ação desse mesmo fornecedor contra a seguradora que se negue a indenizar os valores gastos com a condenação alegando a conduta culposa do segurado: nela se poderá tranquilamente decidir que a conduta deste foi regular e não configura causa excludente do seguro contratado. Haveria aí, tal como resulta das regras gerais da coisa julgada, mera incompatibilidade lógica entre julgados que, por serem praticamente conciliáveis, não é vedada pelo direito processual.

\subsubsection{Síntese: pontos de contato e pontos de diferenciação em relação à coisa julgada material}

Atingido este ponto de nossas considerações sobre a estabilidade da coisa julgada sobre a sentença genérica coletiva de procedência, podemos estabelecer conclusões sobre a sua natureza. Tendo em vista tanto a disciplina legal estabelecida pelo Código de Defesa do Consumidor e pelo Código de Processo Civil, bem como os condicionamentos externos à teoria da coisa julgada, acabamos por definir a coisa julgada coletiva como um instituto sui generis, que não se identifica nem com a coisa julgada material e nem com uma simples preclusão. Tratando-se de vínculo processual que confere indiscutibilidade e imutabilidade às questões decididas na sentença em processos futuros, irradiando eficácia negativa e positiva, pensamos que ela apresenta afinidades e compõe um gênero comum de que a coisa julgada material também é espécie. 
A coisa julgada coletiva é, em seu aspecto objetivo, por um primeiro ângulo de análise, mais ampla do que a coisa julgada material; e por um segundo aspecto ela é mais restrita. Ela é mais ampla no sentido de que ela se concentra sobre o material lógico do processo, especificamente sobre a resolução de questões prejudiciais que influirão na tutela final, e não sobre o dispositivo em que se concentra a coisa julgada material. A coisa julgada coletiva é mais restrita, contudo, porque sua eficácia extraprocessual não abrange todos e quaisquer processos futuros, mas apenas aqueles que digam respeito a um mesmo caso concreto de lesão em massa. Desse ponto de vista, ela se situa em um plano intermediário entre a preclusão e a coisa julgada: sua eficácia não é restrita nem ao processo, mas também não se estende a qualquer controvérsia futura. Trata-se assim de eficácia extraprocessual, mas não panprocessual.

Assim, ela pode ser definida como a indiscutibilidade e a imutabilidade das questões prejudiciais de natureza homogênea resolvidas pela sentença genérica coletiva, no âmbito de processos que tenham por objeto os elementos restantes da mesma lide, delimitada pela pretensão final perseguida em prol dos substituídos e pela causa de pedir comum.

E se é verdade que, tal qual a coisa julgada material do processo comum, ela se orienta por uma finalidade eminentemente prática, os objetivos que ela visa a atender são outros. Ela não pretende assegurar segurança para o vencedor da demanda no gozo de um bem da vida, em todos e quaisquer processos em que a controvérsia vier a ser suscitada. Por incidir sobre uma sentença limitada a alguns aspectos das pretensões reunidas na ação coletiva, que a nosso ver não contém sequer um dispositivo conclusivo a respeito delas, a estabilidade que ela visa a assegurar é preordenada tão somente à integração da resolução dessas lides individuais nos processos complementares de liqüidação individual ou coletiva. Trata-se de uma coisa julgada instrumental, por assim dizer, que desde seu nascedouro já tem sua aplicação definida.

E isso não deve causar estranhamento: como instituto essencialmente prático que sempre foi, em Roma, no processo comum romano-canônico e no processo clássico moderno, a coisa julgada sempre refletiu as características da jurisdição em seu tempo. Parece assim apenas adequado, e uma demonstração de vigor do instituto, que ela assuma 
formas mais maleáveis e funcionais, quando a sua disciplina tradicional começa a dar mostras de não atender mais às necessidades da sociedade contemporânea ${ }^{502}$.

\footnotetext{
${ }^{502}$ Conforme assinala CELSO CAMPILONGO, a transição para o modelo do Estado de bem estar social desloca muitas vezes a preocupação do sistema jurídico da eliminação do conflito para a sua gestão ao longo do tempo. Assim, "a 'coisa julgada', que tinha por objetivo, no Estado liberal, estabilizar a decisão, agora, no direito do Estado social, construído para facilitar a atuação de um Estado dedicado a intervir e transformar a sociedade, torna-se um instrumento de discutível utilidade para algumas situações-limite". (Política, sistema jurídico e decisão judicial, cit., p. 39). Apoiado nessa análise, WALTER PIVA RODRIGUES afirma a "crise" no conceito, indispensável ao Estado de direito, de coisa julgada (Coisa julgada tributária, cit., p. 112).
} 


\section{CONCLUSÕES FINAIS}

1 A transição de uma sociedade rural e agrária ainda predominante no século XIX para uma sociedade urbana e industrial no século XX, e também a transformação do Estado liberal em um Estado de bem-estar que promete prestações positivas a seus cidadãos, tornaram os conflitos mais intensos e padronizados no interior da sociedade, gerando uma profunda crise sobre a teoria do direito e sobre o processo;

2 Essas transformações conduziram a profundas alterações na teoria geral do direito, com a adoção de técnicas legislativas e interpretativas mais fluídas e complexas, e correspondentes alterações no campo do direito processual, renovado por sucessivas ondas que visaram assegurar o acesso à justiça para os necessitados, para os interesses coletivos e massificados, bem como a adoção de uma justiça coexistencial que permita a administração dos conflitos no contexto de relações intensas e duradouras no tempo que caracterizam a sociedade contemporânea;

3 A tutela coletiva pode se dividir em dois ramos afins, mas que requerem técnicas processuais distintas. O primeiro ramo é a tutela de direitos coletivos, relativos a macrointeresses da sociedade, insuscetíveis de apropriação exclusiva e intimamente associados à temática dos direitos sociais. O segundo ramo consiste na tutela coletiva de direitos individuais, que apesar de se amoldarem à estrutura tradicional do direito subjetivo individual, têm por conteúdo também "novos direitos" típicos da sociedade de massas, caracterizados pela uniformidade e pela dispersão;

4 Se a tutela de direitos coletivos teve de romper com barreiras conceituais sedimentadas na teoria geral do direito, relacionadas ao próprio conceito de "direito" passível de proteção em juízo e à estrutura da norma jurídica, a tutela coletiva de direitos individuais é conceitualmente mais simples e apresenta suas maiores dificuldades no campo da técnica processual. Ela apresenta principais duas ordens de desafios para o processo civil: a possibilidade de que os titulares dos interesses individuais venham a ser prejudicados pela atuação do autor coletivo, e a administração do alto grau de complexidade associado a reunião de um grande número de pretensões particularizadas para tratamento comum;

5 O processo coletivo tem uma grande repercussão política, pois na medida em que áreas da vida social que eram privadas do acesso à justiça passam a contar com 
instrumentos que tornam possível a efetivação da ordem jurídica (e eventualmente propiciam abusos), há um deslocamento na balança do poder entre cidadãos e governos, produtores e consumidores, patrões e empregados que, por sua vez, leva a reações dos grupos que se vêem ameaçados por essas mudanças. Por isso, a história do processo coletivo é marcada por avanços e retrocessos;

6 No Brasil, a tutela coletiva teve início com uma interpretação mais ampla da ação popular (Lei $n^{\circ}$ 4.717/65), que passou a ser veiculada para a proteção de interesses que dissessem respeito à qualidade de vida da população. Posteriormente, os principais diplomas que disseminaram foram a Lei da Ação Civil Pública (Lei no 7.347/85), a Constituição de 1988 e o Código de Defesa do Consumidor (Lei n ${ }^{\circ}$ 8.078/90). Ao sistematizar a tutela coletiva, o Código do Consumidor definiu os direitos individuais homogêneos, como aqueles decorrentes de origem comum, e instituiu para sua defesa a ação civil coletiva de responsabilidade pelos danos individualmente sofridos que constitui objeto deste estudo;

7 A característica mais marcante da ação civil coletiva é a reorganização da atividade cognitiva do juiz, mediante a combinação de duas técnicas: a reunião das pretensões individuais dos membros da classe para julgamento conjunto, limitada ao núcleo homogêneo; e a divisão de cada uma das pretensões em processos distintos, de modo que as questões particulares de cada indivíduo são discutidas em processos próprios. Essa solução concilia os objetivos de reduzir a complexidade do conflito coletivo de maneira administrável para o processo, de equilibrar a economia de escala que o litigante habitual tem em discutir as teses uniformes, e de preservar o direito de defesa das partes diante das peculiaridades de cada situação individual;

8 A ação civil coletiva tem por condição específica de admissibilidade a homogeneidade dos direitos da classe representada. O conceito processual de homogeneidade é mais complexo do que a simples "origem comum" do texto legal; por homogêneas se entendem pretensões uniformes, de maneira que nelas prevaleçam os aspectos comuns e se mostre superior a forma coletiva de tutela. Definidos a partir de uma postura pragmática, portanto, direitos individuais homogêneos são aqueles cujas afinidades permitem e tornam conveniente a análise concentrada, em um único processo, dos aspectos comuns a toda uma classe de titulares;

9 No caso de ser julgada procedente a ação civil coletiva, é proferida sentença genérica que fixa a responsabilidade do réu (art. 95 da Lei $n^{\circ} 8.078 / 90$ ). Essa sentença 
exige processos complementares, destinados à resolução das questões pendentes relacionadas ao direito de cada membro da classe. O processo perde então sua natureza coletiva e se individualiza, devendo cada interessado promover ação específica que tenha por objeto a sua habilitação na classe beneficiada pela sentença e a liqüidação do respectivo crédito individual;

10 A legitimação para promover a ação civil coletiva, em substituição processual, é fundada em critérios formais que não asseguram um nexo efetivo de representação entre os membros da classe e o autor coletivo. Por essa razão a sua conduta não pode gerar prejuízos para os titulares das pretensões individuais substituídos em juízo, explicando-se assim que a coisa julgada desfavorável não se estenda aos membros da classe. Pela falta de legitimidade para a prática de atos de disposição, a legitimação extraordinária é limitada à ação coletiva, e não se estende às ações individuais de habilitação e liqüidação, para as quais eventual atuação de associação ou sindicato exige expressa outorga de poderes de representação. $\mathrm{O}$ entendimento firmado pelo STF a respeito da legitimidade dos sindicatos para executar créditos individuais de seus filiados viola o direito de propriedade do titular do direito, merecendo ser revisto;

11 O sistema de divulgação da existência e julgamento da ação coletiva é deficiente, exigindo-se apenas a publicação de editais por ocasião do ajuizamento, e contribui de forma importante para a reduzida eficácia atual do procedimento da ação civil coletiva. O aproveitamento da já existente estrutura de comunicação social do Poder Judiciário, por simples deliberação administrativa, poderia atenuar essa deficiência;

12 A relação estabelecida entre a ação civil coletiva e ações individuais que visem à mesma pretensão de ressarcimento não é de litispendência, ou de continência, mas de prejudicialidade. Não há interferência recíproca de uma sobre as outras a não ser que o autor individual, notificado nos autos do ajuizamento da ação coletiva, requeira a suspensão do processo para se beneficiar de eventual sentença de procedência; optando por prosseguir na ação individual, ele não se beneficiará da sentença genérica, mas seu processo terá curso regular. Assim, a suspensão compulsória de processos individuais, determinada pelo STJ em razão de existir ação coletiva relacionada a diferenças de remuneração e caderneta de poupança, contraria o texto do artigo 104, do Código do Consumidor, embora seja medida que tem a capacidade de contribuir para a desobstrução do aparelho judiciário gerada pelo processamento simultâneo dessas demandas; 
13 A lei define a extensão subjetiva da coisa julgada como erga omnes e secundum eventum litis. De um lado, assim, se assegura que os indivíduos substituídos possam se beneficiar da sentença coletiva sem que tenham sido partes no processo; e de outro, nenhum prejuízo lhes é causado pela sentença de improcedência, se não tiverem intervindo como litisconsortes na ação coletiva;

14 A coisa julgada em matéria de direitos individuais homogêneos, na realidade, sempre se forma para as partes do processo, seja o julgado favorável ou desfavorável, de modo que o regime é coerente com os princípios tradicionais de limitação subjetiva da coisa julgada. O que a lei condiciona ao resultado favorável da ação coletiva é a extensão da coisa julgada a terceiros;

15 A coisa julgada secundum eventum litis confere à ação coletiva um papel secundário e residual para a solução do conflito de massa. Para que o processo coletivo possa cumprir seu papel, assumindo um papel central na solução do conflito coletivo, seria mais adequado um sistema de vinculação da classe aos resultados favoráveis ou desfavoráveis do processo, complementado por um sistema de exclusão que assegurasse aos indivíduos o direito de promoverem suas próprias demandas (opt-out);

16 Ultrapassada a ideologia positivista, que pretendeu viabilizar um estudo politicamente neutro do processo a partir de institutos como a ação ou o objeto litigioso, atualmente doutrina vem convergindo para adotar a jurisdição como pólo metodológico do direito processual. Adotando essa premissa, pudemos identificar condicionantes para a teoria da coisa julgada que decorrem do modo como a jurisdição se insere no mecanismo do poder no moderno Estado de direito;

17 A teoria da divisão das funções estatais entre os poderes tem por conseqüência a teoria dualista do ordenamento, por meio da qual se compreendem direito material e processo em planos separados, e pela qual a função do processo é a aplicação do direito preexistente aos casos concretos em uma atividade eminentemente declarativa. Isto não significa que o juiz nada crie ao interpretar a lei, mas sim que a decisão deve ser fundada em parâmetros racionais que possam ser conduzidos ao seu texto;

18 A adoção da teoria dualista, que enxerga o processo como instrumento para a efetivação do direito material, implica em que a unidade mínima estrutural do processo deva ser constituída por uma relação jurídica, de modo que o objeto do processo não pode consistir em nada menos do que o pedido de tutela a um interesse concreto protegido pela 
lei. Não se admite que a jurisdição seja utilizada para a declaração de fatos históricos, ou de teses jurídicas a que não estejam ligados um efeito jurídico concreto;

19 Da autonomia do direito processual também se extrai a conseqüência de que a coisa julgada não se confunde com o direito material reconhecido pela sentença, o que torna a estabilidade da decisão uma regra de processo civil dirigida aos juízes de processos futuros;

20 O desenvolvimento da teoria da coisa julgada, no século XIX, teve por tônica a crescente publicização do instituto. Ainda no início do século foi superada a teoria da ficção de verdade, que trazia resquícios do processo comum medieval. Posteriormente, a doutrina se dividiu em duas correntes: a teoria material da coisa julgada, de inspiração privatística, que equiparava a sentença a um contrato declarativo e confundia a coisa julgada com a própria sentença; e a teoria processual, que tratava a coisa julgada de forma autônoma, inicialmente enxergando nela como a eficácia da declaração contida na sentença;

21 Contestando a teoria da eficácia da declaração, LIEBMAN deu um passo decisivo para a teorização do instituto ao separar os conceitos de eficácia natural da sentença, entendida como as alterações que a decisão judicial introduz na realidade jurídica; e de autoridade da coisa julgada, compreendida como uma qualidade que se agrega a sentença para torná-la estável. Ao definir esta última como qualidade da sentença que torna seus efeitos imutáveis, porém, sua teoria pecou por situar a imutabilidade nos efeitos da sentença, que são transitórios por natureza. Na doutrina brasileira, BOTELHO DE MESQUITA trouxe maior clareza para a separação entre a coisa julgada e os efeitos da sentença ao distinguir o elemento declaratório, que é o juízo final contido em todas as sentenças, do efeito declaratório próprio às sentenças que julgam procedente a pretensão declaratória. Esse juízo final, portanto, é que se torna protegido pela coisa julgada;

22 A coisa julgada consiste, portanto, na imutabilidade e na indiscutibilidade do elemento declaratório das sentenças de mérito, por efeito do trânsito em julgado. O elemento declaratório consiste no raciocínio último do juiz sobre o mérito da causa, e não se confunde com o efeito declaratório irradiado pelas sentenças que julgam procedente a pretensão de declaração. A imutabilidade (efeito negativo) impede uma nova decisão sobre a causa, e a indiscutibilidade vincula o juiz a julgar de acordo com o decidido se o objeto do julgado surgir como questão prejudicial em outro processo; 
23 O instrumento técnico em que se apóia a coisa julgada é a eficácia preclusiva, que proíbe a rediscussão da causa pela renovação das questões deduzidas ou dedutíveis no processo em que foi dada a decisão. A tese de relativização da coisa julgada por contrariedade à Constituição, que se popularizou na doutrina brasileira nos últimos anos, busca afastar a preclusão das questões de ordem constitucional, em um regresso ao tratamento medieval do instituto;

24 A coisa julgada é limitada à lide, que é conceito complexo que transcende o objeto da pretensão veiculado pela demanda. Assim, a coisa julgada se estende, por razões lógicas e práticas, a pretensões incompatíveis, inclusas e implicadas pela decisão, bem como a outras que sejam praticamente inconciliáveis com o decidido;

25 Objeto da coisa julgada é apenas aquilo que foi decidido pelo juiz. Em caso de incongruência entre a demanda e a sentença, o que se torna imutável e indiscutível é o que consta desta última. O que foi decidido sem que houvesse pedido faz coisa julgada, e o que foi pedido e não decidido pode ser novamente deduzido em juízo;

26 No plano objetivo, a coisa julgada é delimitada pelo objeto do processo, que consiste no pedido qualificado pela causa de pedir. Quanto à causa de pedir, devem ser repelidas as posições extremas entre as teorias da individuação e da substanciação, porque pelo critério da hipótese normativa prevista pelo direito material, tanto os fatos como o fundamento jurídico podem se mostrar relevantes para a identificação da pretensão;

27 Os elementos lógicos pelos quais o juiz constrói seu raciocínio, contidos na motivação da sentença, de regra não fazem coisa julgada. Enquanto a impossibilidade da aquisição de estabilidade extraprocessual pelos fatos representados no processo e pelo raciocínio jurídico desenvolvido pelo juiz é mais clara, pelo caráter puramente instrumental desses elementos de raciocínio, as questões prejudiciais resolvidas incidentalmente pelo juiz também são resultado da aplicação do direito ao caso concreto, de modo que se debate se elas devem ser abrangidas pela coisa julgada. Considerando que sobre elas o contraditório é menos intenso e a cognição do juiz mais superficial, a lei brasileira optou por excluí-las da coisa julgada. Entretanto, desde que a questão prejudicial possa constituir uma causa prejudicial que possa ser decidida pelo mesmo juiz, é facultado às partes requererem a sua declaração incidental, hipótese em que haverá ampliação do objeto do processo pelo cúmulo de duas pretensões; 
28 A limitação subjetiva da coisa julgada foi objeto de um movimento pendular. No processo comum medieval, em que o contraditório tinha grande importância, teve larga aplicação a Lex Saepe romana, que limitava a coisa julgada às partes. Na fase publicística do processo, em que a jurisdição passou a se apoiar na autoridade do Estado, desenvolveuse a teoria dos efeitos reflexos, pelo qual os terceiros interessados se vinculam à coisa julgada. Conforme também a participação pelo contraditório adquiriu importância no processo moderno, passou a predominar a construção de LIEBMAN, segundo a qual todos se subordinam aos efeitos da sentença, enquanto a autoridade da coisa julgada fica limitada às partes. Com isso, o terceiro interessado tem a oportunidade de demonstrar em processo próprio a injustiça da decisão, e assim se furtar aos seus efeitos. Também se submetem à coisa julgada os adquirentes do direito litigioso e, em alguns casos, a depender da intensidade do vínculo que constitui a situação legitimante, os substituídos em juízo por legitimado extraordinário;

29 A coisa julgada constitui pressuposto processual negativo quando a demanda for reiterada (eficácia negativa), e regra de julgamento quando o objeto do julgado surgir como questão prejudicial em um segundo processo (eficácia positiva). Em qualquer hipótese, a sentença que a desconsiderar será passível de anulação, mas se a questão não for suscitada, também essa matéria será atingida pela eficácia preclusiva e prevalecerá a segunda sentença, mesmo que tenha sido dada contra a coisa julgada;

30 Do ponto de vista dogmático, a sentença genérica coletiva se enquadra na categoria das sentenças parciais de mérito. O conceito, desenvolvido por CARNELUTTI, remete às situações em que a solução de uma mesma pretensão é dividida em sucessivos processos, cujo conteúdo individual é inferior à unidade mínima estrutural necessária para que a jurisdição declare o direito aplicável à hipótese concreta;

31 A sentença parcial de mérito tem estrutura diferente da sentença de mérito ordinária. Nela pode ser encontrado o relatório, bem como a resolução das questões de fato ou direito que tenham constituído objeto do processo. O dispositivo, contudo, é incompleto e não se aperfeiçoa. Como o processo não examina a integralidade dos elementos pertinentes à tutela da pretensão deduzida em juízo, não há a manifestação de vontade estatal sobre o efeito jurídico ligado ao caso concreto;

32 Como a repartição da atividade cognitiva torna necessária, para a entrega da tutela final, a sua complementação em processos ulteriores, a coisa julgada adquire uma nova função, estranha à coisa julgada tradicional: em lugar de assegurar o gozo de um bem 
da vida reconhecido pela sentença de mérito, ela desempenha o papel de regular a articulação estrutural entre as sentenças parciais voltadas à tutela de uma mesma pretensão;

33 Uma primeira linha de análise sobre a coisa julgada parcial buscou explicar o fenômeno como espécie de preclusão extraprocessual sobre as questões decididas. O pressuposto adotado por essa corrente é o de que apenas decisões que reconhecessem ou negassem um bem da vida (uma pretensão processual) seriam passíveis de adquirir a proteção da coisa julgada. A teoria peca, contudo, pelo fato de que o conceito de preclusão teve de ser desnaturado para que se pudesse nele enquadrar os vínculos irradiados pela sentença parcial;

34 Posteriormente, uma segunda corrente defendeu que não havia razão que impedisse a formação de coisa julgada sobre questões de fato ou direito. Essas teorias também não são satisfatórias, porque a solução de questões em abstrato torna imprevisíveis as consequiências da coisa julgada, com potencial prejuízo ao direito de ação e de defesa das partes e ao devido processo legal;

35 Uma terceira corrente propugnou por uma solução intermediária, segundo a qual a coisa julgada se forma sobre a fattispecie concreta parcialmente decidida. Há assim uma ampla vinculação do juiz, em sentido preclusivo (efeito negativo) e conformativo (efeito positivo) que tem por objeto todas as questões resolvidas, mas exclusivamente no âmbito de processos que se voltem à solução do mesmo caso concreto. A coisa julgada sobre questões, sempre prejudiciais para a resolução de uma pretensão concreta não exaurida pelo processo parcial, não gera qualquer prejuízo para as partes porque desde logo elas têm conhecimento da finalidade para a qual se volta a decisão daquelas questões. E as questões não se resolvem em abstrato, mas sempre tendo em vista a aplicação da lei a uma hipótese concreta. Essa teoria nos parece a mais correta, assim, por conseguir compatibilizar a indiscutibilidade das questões resolvidas aos princípios gerais da coisa julgada;

36 No Brasil, o caráter residual das sentenças parciais no sistema do Código de Processo Civil de 1973 impediu um desenvolvimento sistemático da teoria da coisa julgada parcial. Entretanto, para a hipótese de maior importância prática - o pedido genérico - a doutrina e jurisprudência desenvolveram o "princípio da fidelidade da liqüidação ao título", que admite ampla vinculação do juízo do processo complementar de liqüidação às questões de fato e direito resolvidas na sentença genérica, com a admissão de que pode 
ocorrer uma liqüidação-zero se não for provada ocorrência do dano. O princípio da fidelidade da liqüidação ao título, intuitivamente construído, atinge resultados que são coerentes com a da teoria da coisa julgada parcial sobre a fattispecie e com a teoria geral da coisa julgada;

37 A coisa julgada coletiva não pode ser entendida como simples expansão de eficácia da sentença. Isto porque a sentença genérica coletiva não irradia alterações sobre a realidade jurídica; antes, produz vínculos para os processos futuros que impedem a reiteração da mesma demanda (efeito negativo) e obrigam os juízes dos processos futuros a julgar de acordo com o que nela houver sido decidido (efeito positivo), elementos que possibilitam defini-la como uma modalidade de coisa julgada, que, embora afim, não se confunde com a coisa julgada material;

38 Aplicando as premissas da coisa julgada parcial sobre a sentença genérica coletiva de procedência, podemos concluir que se tornam imutáveis e indiscutíveis todas as questões de natureza homogênea resolvidas pelo juiz. Essas questões têm a natureza de questões prejudiciais à resolução de cada pretensão individual parcialmente decidida pela sentença genérica. A eficácia extraprocessual da coisa julgada coletiva se fará sentir apenas em processos que se voltem ao mesmo caso concreto, que é a lesão de massa descrita pela causa de pedir da ação civil coletiva;

39 Ao contrário do sugerido pela redação do artigo 95 da Lei $n^{\circ} 8.078 / 90$, o objeto da coisa julgada sobre sentença genérica coletiva não é uma abstrata declaração de responsabilidade do réu. O seu objeto é a resolução dada pelo juiz às questões prejudiciais de natureza homogênea, e isso confere à coisa julgada coletiva um objeto dinâmico e variável, a depender da extensão do núcleo de homogeneidade frente à margem de heterogeneidade das pretensões individuais dos membros da classe;

40 Disso decorre que a abrangência da coisa julgada coletiva permite que, no âmbito do caso concreto da lesão de massa, haja uma ampla vinculação às questões prejudiciais resolvidas pela sentença, de modo que se permite ou a prévia liqüidação, ou o estabelecimento de parâmetros uniformes de liqüidação para as pretensões individuais, desde que estes sejam elementos homogêneos entre a classe;

41 O início da liqüidação dos créditos individuais pela sentença coletiva é de particular utilidade em casos em que a prova do montante dos danos é complexa ou dispendiosa, em que a barreira econômica para o acesso à justiça se encontra justamente na 
apuração do quantum debeatur, ou nas situações em que o conteúdo da obrigação deva necessariamente ser arbitrado pelo juiz, em que a prévia liqüidação assegura tratamento isonômico para os membros da classe;

42 O reconhecimento desse objeto fluído e móvel da coisa julgada coletiva, se por um lado pode contribuir para o aumento de eficácia e utilidade da sentença genérica coletiva, por outro lado pode surpreender as partes e lhes causar prejuízo processual se não houver a prévia fixação pelo juiz das questões a serem resolvidas na fase coletiva, na forma do artigo 331, §2º do CPC. Na ação civil coletiva, a fixação dos pontos controvertidos é consideravelmente mais complexa, porque exige a própria análise da viabilidade do tratamento coletivo de cada questão. Desse modo, a decisão do juiz a respeito irá moldar o próprio objeto do processo (“defining function”), aproximando as providências preliminares, nesse procedimento, da decisão de certification que se encontra nas class actions do direito norte-americano;

43 A circunscrição da coisa julgada sobre a sentença genérica coletiva ao caso concreto também gera um efeito limitativo. A coisa julgada somente beneficia as vítimas e sucessores da mesma lesão de massa discutida na ação civil coletiva, de modo que em pretensões conexas, caracterizadas por não se subsumirem à causa de pedir homogênea, as questões resolvidas podem ser livremente resolvidas pelo juiz, mesmo em sentido contrário. 


\section{REFERÊNCIAS BIBLIOGRÁFICAS}

ALEXY, Robert. Teoría de los derechos fundamentales. 2. ed. Madrid: Centro de Estudios Políticos e Constitucionales, 2007.

ALLORIO, Enrico. La cosa giudicata rispetto ai terzi. Ristampa. Milano: Giuffré, 1992. . Critica alla teoria del giudicato implicito. Rivista di Diritto Processuale, Padova, v. 13, n. 2, 1938.

ALMEIDA, Gregório Assagra de. Codificação do direito processual coletivo brasileiro. Belo Horizonte, Del Rey, 2007.

Direito processual coletivo brasileiro: um novo ramo do direito processual: princípios, regras interpretativas e a problemática de sua interpretação e aplicação. São Paulo: Saraiva, 2003.

ALMEIDA, João Batista de. A ação civil coletiva para a defesa de interesses ou direitos individuais homogêneos. Revista de Direito do Consumidor, São Paulo, v. 9, n. 34, p.8897, abr./jun. 2000.

Aspectos controvertidos da ação civil pública: doutrina e jurisprudência. São Paulo: Ed. Revista dos Tribunais, 2001.

ALSINA, Hugo. Tratado teorico practico de derecho procesal civil y comercial. 2. ed. Buenos Aires: Ediar, 1956.

ALVIM NETTO, José Manoel Arruda. Manual de direito processual civil. 14. ed. São Paulo: Ed. Revista dos Tribunais, 2011.

Notas atuais sobre a figura da substituição processual. Revista de Processo, São Paulo, n. 106, p. 28-37, abr./jun. 2002.

. Notas sobre a coisa julgada coletiva. Revista de Processo, São Paulo, n. 88, p. 3157, out./dez. 1997.

AMERICANO, Jorge. Processo civil e commercial no direito brasileiro: phases probatória, decisória e executória. São Paulo: Livraria Acadêmica Saraiva, 1925.

ANDRIOLI, Virgilio. Il principio di diritto enunciato dalla Corte di Cassazione. Rivista di Diritto Processuale, Padova, v. 7, p. 279-288, 1952.

ARAGÃO, Egas Dirceu Moniz de. Notas sobre liqüidação de sentença. Revista de Processo, São Paulo, n. 44, p. 21-30, out./dez. 1986. 
ARAÚJO FILHO, Luiz Paulo da Silva. Ações coletivas: a tutela jurisdicional dos direitos individuais homogêneos. Rio de Janeiro: Forense, 2000.

Sobre a distinção entre interesses coletivos e interesses individuais homogêneos. In: FUX, Luiz; NERY Jr., Nelson; WAMBIER, Teresa Arruda Alvim (Orgs.). Processo e Constituição: estudos em homenagem ao Professor José Carlos Barbosa Moreira. São Paulo: Ed. Revista dos Tribunais, 2006.

ARENHART, Sérgio Cruz. A tutela de direitos individuais homogêneos e as demandas ressarcitórias em pecúnia. In: GRINOVER, Ada Pellegrini; MENDES, Aluísio Gonçalves de Castro; WATANABE, Kazuo (Coords.). Direito processual coletivo e o Anteprojeto de Código Brasileiro de Processos Coletivos. São Paulo: Ed. Revista dos Tribunais, 2007.

ARISTÓTELES. A política. 3. ed. São Paulo: Martins Fontes, 2006.

ARMELIN, Donaldo. A legitimidade para agir no direito processual civil brasileiro. São Paulo: Ed. Revista dos Tribunais, 1979.

ASSIS, Araken de. Comentários ao Código de Processo Civil. Rio de Janeiro: Forense, 2000. v. 6.

Cumprimento de sentença. 3. ed. Rio de Janeiro: Forense, 2010.

Substituição processual. Revista Síntese de Direito Civil e Processual Civil. Porto Alegre, v. 5, n. 26, p. 45-64, nov./dez. 2003.

AURELIANO DE GUSMÃO, Manoel. Cousa julgada. São Paulo: Duprat, 1914.

AZAMBUJA, Carmen Luiza Dias de. Rumo a uma nova coisa julgada. Porto Alegre: Livraria do Advogado, 1994.

BADIN, Artur. O fundo de defesa dos direitos difusos. Revista de Direito do Consumidor, São Paulo, v. 67, jul./set. 2008.

BALLESTEROS, Maria Teresa de Padura. Fundamentación de la sentencia, preclusión y cosa juzgada: su régimen en la LEC 1/2000. Valencia: Tirant lo Blanch, 2002.

BARAK, Aharon. The judge in a democracy. Princeton: Princeton University Press, 2006.

BARBOSA MOREIRA, José Carlos. A ação popular do direito brasileiro como instrumento de tutela jurisdicional dos chamados "interesses difusos". In: Temas de direito processual: $1^{\mathrm{a}}$ série. 2. ed. São Paulo: Saraiva, 1988. p. 110-123.

Ainda e sempre a coisa julgada. In: Direito processual civil: ensaios e pareceres. Rio de Janeiro: Editor Borsói, 1971. p. 133-146. 
BARBOSA MOREIRA, José Carlos. Apontamentos para um estudo sistemático da legitimação extraordinária. In: Direito processual civil: ensaios e pareceres. Rio de Janeiro: Editor Borsói, 1971. p. 58-72.

Coisa julgada e declaração. In: Temas de direito processual: $1^{\mathrm{a}}$ série. 2 . ed. São Paulo: Saraiva, 1988. p. 81-89.

. Considerações sobre a chamada "relativização" da coisa julgada material. Revista Síntese de Direito Civil e Processual Civil, Porto Alegre, v. 6, n. 33, p. 5-28, jan./fev. 2005.

Conteúdo e efeitos da sentença: variações sobre o tema. In: Temas de direito processual: $4^{\mathrm{a}}$ série. São Paulo: Saraiva, 1989. p. 175-183.

Correlação entre o pedido e a sentença. Revista de Processo, São Paulo, n. 83, jul./set. 1996.

A eficácia preclusiva da coisa julgada material no sistema do processo civil brasileiro. In: . Temas de direito processual: $1^{\text {a }}$ série. 2. ed. São Paulo: Saraiva, 1988. p. 97-109.

Eficácia da sentença e autoridade da coisa julgada. In: Temas de direito processual: $3^{\text {a }}$ série. São Paulo: Saraiva, 1994. p. 99-113.

. Os limites objetivos da coisa julgada no sistema do novo Código de Processo Civil. In: . Temas de direito processual: $1^{\mathrm{a}}$ série. 2. ed. São Paulo: Saraiva, 1988. p. 90-96.

. Litisconsórcio unitário. Rio de Janeiro: Editor Borsói, 1972.

Questões prejudiciais e coisa julgada. Rio de Janeiro: Editor Borsói, 1967. [Apresentada como Tese de Concurso para a docência livre de Direito Judiciário Civil, apresentada à Congregação da Faculdade de Direito da Universidade Federal do Rio de Janeiro].

Questões prejudiciais e questões preliminares. In: Direito processual civil: ensaios e pareceres. Rio de Janeiro: Editor Borsói, 1971. p. 73-93.

Tutela jurisdicional dos interesses coletivos ou difusos. Revista de Processo, São Paulo, n. 39, p. 55-77, jul./set. 1985.

BARROSO, Luis Roberto. A proteção coletiva dos direitos no Brasil e alguns aspectos da class action norte-americana. Revista Forense, Rio de Janeiro, v. 101, n. 381, p. 103-19, set./out. 2005. 
BAZILONI, Nilton Luiz de Freitas. A coisa julgada nas ações coletivas. São Paulo: Juarez de Oliveira, 2004.

BECK, Ulrich. A reinvenção da política: rumo a uma teoria da modernização reflexiva. In: GIDDENS, Anthony; BECK, Ulrich; LASH, Scott. Modernização reflexiva: política, tradição e estética na ordem social moderna. São Paulo: Ed. da Universidade Estadual Paulista, 1994.

The risk society: towards a new modernity. London: Sage Publications, 1992.

BEDAQUE, José Roberto dos Santos. Direito e processo. 4. ed. São Paulo: Malheiros Ed., 2006.

2007.

Efetividade do processo e técnica processual. 2. ed. São Paulo: Malheiros Ed.,

. Poderes instrutórios do juiz. 4. ed. São Paulo: Ed. Revista dos Tribunais, 2009.

BICKEL, Alexander. The least dangerous branch. 2. ed. Yale University Press: New Haven and London, 1986.

BOBBIO, Norberto. Liberalismo e democracia. São Paulo: Brasiliense, 2007.

O positivismo jurídico: lições de filosofia do direito. São Paulo: Ícone, 2006.

BOTELHO DE MESQUITA, José Ignácio. Na ação do consumidor, pode ser inútil a defesa do fornecedor. Revista do Advogado, São Paulo, n. 33, p. 80-81, dez. 1990.

. A autoridade da coisa julgada e a imutabilidade da motivação da sentença. In:

Teses, estudos e pareceres de processo civil: jurisdição e competência - sentença e coisa julgada - recursos e processos de competência originária dos tribunais. São Paulo: Ed. Revista dos Tribunais, 2005. v. 2.

. A causa petendi nas ações reivindicatórias. In: Teses, estudos e pareceres de processo civil: direito de ação - partes e terceiros - processo e política. São Paulo: Ed. Revista dos Tribunais, 2005. v. 1.

. A coisa julgada. Rio de Janeiro: Forense, 2006.

A coisa julgada no Código do Consumidor. In: . A coisa julgada. Rio de Janeiro: Forense, 2006. p. 21-42.

Coisa julgada - efeito preclusivo. In: . A coisa julgada. Rio de Janeiro: Forense, 2006. p. 65-88.

A coisa julgada. In: . A coisa julgada. Rio de Janeiro: Forense, 2006. p. 1-19. 
BOTELHO DE MESQUITA, José Ignácio. A coisa julgada - síntese da exposição do tema. In: Teses, estudos e pareceres de processo civil: jurisdição e competência sentença e coisa julgada - recursos e processos de competência originária dos tribunais. São Paulo: Ed. Revista dos Tribunais, 2005. v. 2.

Conflito entre a intangibilidade da coisa julgada e outro princípio constitucional: um falso problema. In: A coisa julgada. Rio de Janeiro: Forense, 2006.

A crise do judiciário e o processo. In: Teses, estudos e pareceres de processo civil: direito de ação - partes e terceiros - processo e política. São Paulo: Ed. Revista dos Tribunais, 2005. v. 1, p. 255-262.

. Da ação civil. In: Teses, estudos e pareceres de processo civil: direito de ação - partes e terceiros - processo e política. São Paulo: Ed. Revista dos Tribunais, 2005. v. 1.

Da autoridade civil da coisa julgada penal. In: A coisa julgada. Rio de Janeiro: Forense, 2006. p. 43-64.

. As novas tendências do direito processual: contribuições para seu reexame. In: . Teses, estudos e pareceres de processo civil: direito de ação - partes e terceiros processo e política. São Paulo: Ed. Revista dos Tribunais, 2005. v. 1, p. 263-307.

; LOMBARDI, Mariana Capela; AMADEO, Rodolfo Costa Manso; DELLORE, Luiz Guilherme Pennacchi e ZVEIBIL, Daniel Guimarães. O colapso das condições da ação? um breve ensaio sobre os efeitos da carência de ação. Revista do Advogado, São Paulo, v. 88, p. 109-127, 2006.

BUENO, Cássio Scarpinella. As class actions norte-americanas e as ações coletivas brasileiras: pontos para uma reflexão conjunta. Revista de Processo, São Paulo, n. 82, p. 92-151, abr./jun. 1996.

Partes e terceiros no processo civil brasileiro. 2. ed. São Paulo: Saraiva, 2006.

Tutela coletiva em juízo: uma reflexão sobre a alteração proposta para o art. 81, parágrafo único, inciso III, do CDC. Revista do Advogado, São Paulo, p. 18-30, dez. 2011.

BULOW, Oskar. La teoría de las excepciones procesales y los presupuestos procesales. Trad. española. Buenos Aires: Europa-America, 1968.

BUZAID, Alfredo. Ação declaratória. São Paulo: Livraria acadêmica Saraiva e Cia., 1943.

Da lide: estudo sobre o objeto litigioso (1980). In: Estudos e pareceres de direito processual civil, São Paulo: Ed. Revista dos Tribunais, 2002. p. 72-132. 
BUZAID, Alfredo. Da liquiidação por artigos em ação de ressarcimento de perdas e danos. Revista de Processo, São Paulo, n. 43, p. 9-13, jul./set. 1986.

Do agravo de petição no sistema do Código de Processo Civil. 2. ed. São Paulo: Saraiva, 1956.

CALAMANDREI, Piero. Il concetto di $<<$ lite $>>$ nel pensiero di Francesco Carnelutti. In: CAPPELLETTI, Mauro (a cura di). Opere giuridiche. Napoli: Morano, 1965. v. 1, p. 200226.

La condanna $<<$ gennerica $>$ ai danni. In: CAPPELLETTI, Mauro (a cura di). Opere giuridiche. Napoli: Morano, 1965. v. 5, p. 503-530.

La genesi logica della sentenza civile. In: CAPPELLETTI, Mauro (a cura di). Opere giuridiche. Napoli: Morano, 1965. v. 1, p. 11-54

- Limiti fra giurisdizione e amministrazione nella sentenza civile. In: CAPPELLETTI, Mauro (a cura di). Opere giuridiche. Napoli: Morano, 1965. v. 1, p. $65-$ 93.

CALVOSA, Carlo. Omisione di pronuncia e cosa giudicata. Rivista di Diritto Processuale Civile, Padova, 1950. v. 5.

CÂMARA, Alexandre Freitas. Lições de direito processual civil. Rio de Janeiro: Lumen Iuris, 2005. v. 1.

CAMPILONGO, Celso Fernandes. Política, sistema jurídico e decisão judicial. 2. ed. São Paulo: Saraiva, 2011.

CAMPOS, Ephraim de. Substituição processual. São Paulo: Ed. Revista dos Tribunais, 1985.

CAMPOS, Ronaldo Cunha. Limites objetivos da coisa julgada. Rio de Janeiro: Aide, 1988.

CAPONI, Remo. Il giudicato civile dimensionato. Rivista trimestrale de diritto $e$ procedura civile, anno 63, n. 3, p. 941-954, set. 2009.

. L'efficacia del giudicato civile nel tempo. Milano: Giuffrè, 1991.

CAPPELLETTI, Mauro. O acesso à justiça como programa de reformas e método de pensamento. Revista Forense, Rio de Janeiro, v. 104, n. 395, p. 209-224, jan/fev. 2008.

La dimensione sociale: l'acesso alla giustizia. In: Dimensioni della giustizia nelle società contemporanee. Bologna: Il Mulino, 1994. p. 71-72.

- Formações sociais e interesses coletivos diante da justiça civil. Revista de Processo, São Paulo, n. 5, p. 128-159, jan./mar. 1977. 
CAPPELLETTI, Mauro. Juízes legisladores? Trad. de Carlos Alberto Alvaro de Oliveira. Porto Alegre: Sérgio Antonio Fabris, 1993.

; BRYANT, Garth. Acesso à justiça. Porto Alegre: Sérgio Antonio Fabris Editor, 1998.

CARMONA, Carlos Alberto. O processo de liqüidação de sentença. Revista de Processo, São Paulo, n. 60, p. 44-55, out./dez. 1990.

CARNEIRO, Athos Gusmão. Ação civil pública - direitos individuais homogêneos, limitações à sua tutela pelo Ministério Público. Revista Síntese de Direito Civil $e$ Processual Civil, Porto Alegre, v. 2, n. 12, p. 5-13, jul./ago. 2001.

Cumprimento da sentença civil e procedimentos executivos. 2. ed. Rio de Janeiro: Forense, 2011.

CARNELUTTI, Francesco. Bilancio di uma polemica. In: Studi di processo civile. Padova: Cedam, 1939.

. Capo di sentenza. In: Studi di processo civile. Padova: Cedam, 1939.

- Casi clinici. Effetti della cassazione per omessa pronunzia. Rivista di Diritto Processuale, Padova, v. 15, 1938.

Condanna generica al risarcimento del danno. Rivista di Diritto Processuale, Padova, v. 1, 1956.

. Cosa giudicata parziale. Rivista di Diritto Processuale, Padova, v. 2, 1956.

. Diritto e processo. Napoli: Morano, 1958.

. Efficacia, autorità e immutabilità dela sentenza. In: Studi di processo civile. Padova: Cedam, 1939.

Lezioni di diritto processuale civile. Padova: La Litotipo, 1927. v. 4.

Lite e processo. In: . Studi di processo civile. Padova: Cedam, 1939. v. 3.

CARVAlHO, Milton Paulo de. Do pedido no processo civil. Porto Alegre: Sérgio Antonio Fabris Editor, 1992.

CHAYES, Abraham. The role of the judge in public law litigation. Harvard Law Review, v. 89, May 1976.

CHIOVENDA, Giuseppe. Cosa giudicata e competenza. In: SAGGI di diritto processuale civile. Milano: Giuffrè, 1993, v. 2, p. 411-425. 
CHIOVENDA, Giuseppe. Cosa giudicata e preclusione. In: SAGGI di diritto processuale civile. Milano: Giuffrè, 1993, v. 3, p. 231-283.

Instituições de direito processual civil. 3. ed. Trad. J. Guimarães Menegale. São Paulo: Saraiva, 1969. v. 1.

L'idea romana nel processo civile moderno. In: SAGGI di diritto processuale civile. Milano: Giuffrè, 1993, v. 3, p. 77-94.

Romanesimo e germanesimo nel processo civile. In: SAGGI di diritto processuale civile. Milano: Giuffrè, 1993, v. 1, p. 181-225.

Sulla cosa giudicata. In: SAGGI di diritto processuale civile. Milano: Giuffrè, 1993, v. 2, p. 399-409.

CINTRA, Antonio Carlos de Araújo. Comentários ao Código de Processo Civil: arts 332 a 475. 2. ed. Rio de Janeiro: Forense, 2003. v. 4.

; GRINOVER, Ada Pellegrini; DINAMARCO, Cândido Rangel. Teoria geral do processo. 22. ed. São Paulo: Malheiros Ed., 2006.

CINTRA, Antonio Carlos Fontes. Interesses individuais homogêneos: natureza e oportunidade de coletivização dos interesses individuais. Revista de Direito do Consumidor, n. 72, p. 9-40, out./dez. 2009.

COASE, Ronald. The problem of social cost. In: The firm, the market and the law. Chicago: University of Chicago Press, 1988. p. 95-156.

CONSOLO, Claudio; BONA, Marco; BUZZELLI, Paolo. Obiettivo class action: l'azione colletiva risarcitoria. Lavis: Wolters Kluwer, 2008.

COSTA, Daniel Carnio. Danos individuais e ações coletivas. Curitiba: Juruá, 2009.

COSTA, Suzana Henriques. Condições da ação. São Paulo: Quartier Latin, 2005.

O controle judicial da representatividade adequada: uma análise dos sistemas norte-americano e brasileiro. In: SALLES, Carlos Alberto de (Coord.). As grandes transformações do processo civil brasileiro: homenagem ao professor Kazuo Watanabe. São Paulo: Quartier Latin, 2009. p. 953-978.

COUTO, Guadalupe Louro Turos. A efetividade da liqüidação e da execução da tutela jurisdicional coletiva na área trabalhista e o Código Brasileiro de Processos Coletivos. In: GRINOVER, Ada Pellegrini, MENDES, Aluisio Gonçalves de Castro; WATANABE, Kazuo (Orgs.). Direito processual coletivo e o anteprojeto de Código Brasileiro de Processos Coletivos. São Paulo: Ed. Revista dos Tribunais, 2007. p. 291-308. 
COUTURE, Eduardo. Fundamentos del derecho procesal civil. 4. ed. Montevideo-Buenos Aires: Editorial B de F, 2007.

CRESCI SOBRINHO, Elício de. Coisa julgada. Revista de Processo, São Paulo, n. 65, p. 235-252, jan./mar. 1992.

CRUZ E TUCCI, José Rogério. A causa petendi no processo civil. 3. ed. São Paulo: Ed. Revista dos Tribunais, 2009.

. Limites subjetivos da eficácia da sentença e da coisa julgada civil. São Paulo: Ed. Revista dos Tribunais, 2006.

Limites subjetivos da eficácia da sentença e da coisa julgada nas ações coletivas, In: _. O advogado, a jurisprudência e outros temas de processo civil. São Paulo: Quartier Latin, 2010. p. 175-206.

; AZEVEDO, Luiz Carlos. Lições de história do processo civil lusitano. São Paulo: Ed. Revista dos Tribunais; Coimbra: Coimbra Ed., 2009.

CUNHA, Alcides Munhoz da. Correlação lógica entre cognição, preclusão e coisa julgada. Revista de Processo, São Paulo, n. 163, p. 359-375, set. 2008.

CUNHA, Leonardo José Carneiro da. Coisa julgada e execução no processo coletivo. Revista dos Tribunais, São Paulo, n. 784, p. 68-82, fev. 2001.

D'ONOFRIO, Paolo. Sul concetto di preclusione. In: Studi di diritto processuale in onore di Giuseppe Chiovenda nel venticinquesimo anno del suo insegnamento. Padova: CEDAM, 1927. p. 427-437.

DALFINO, Domenico. Questioni di diritto e giudicato: contributo allo studio dell'ccertamento delle “fattispecie preliminari”. Torino: G. Giappichelli Editore, 2008.

DELGADO, José Augusto. Aspectos controvertidos da substituição processual. Revista de Processo, São Paulo, n. 47, p. 7-16, jul./set. 1987.

DELLORE, Luiz Guilherme Pennacchi. Da ampliação dos limites objetivos da coisa julgada no novo Código de Processo Civil: quieta non movere. Revista de Informação Legislativa, Brasília, ano 48, n. 190, p. 35-43, abr./jun. 2011.

Das sentenças que não são cobertas pela coisa julgada no direito processual civil brasileiro. 2006. Dissertação (Mestrado). Faculdade de Direito da Universidade de São Paulo, São Paulo, 2006.

Fundo federal de reparação de direitos difusos: aspectos atuais e análise comparativa com institutos norte-americanos. Revista de Direito Ambiental, São Paulo, n. 38, p. 124-139, 2005. 
DENTI, Vittorio. Ancora sull'efficacia della decisione di questioni preliminari di merito. In: Dall'azione al giudicato. Padova: CEDAM, 1983.

. I giudicati sulla fattispecie. In: Scritti giuridici in memoria di Piero Calamandrei. Padova: CEDAM, 1958. v. 3.

Sentenze non definitive su questione preliminare di merito e cosa giudicata. Rivista di Diritto Processuale, Padova, 1969.

DIDIER JR., Fredie; ZANETI JR., Hermes. Curso de direito processual civil: processo coletivo. 6. ed. Salvador: Juspodium Ed., 2011. v. 4.

DINAMARCO, Cândido Rangel. Capítulos de sentença. 3. ed. São Paulo: Malheiros Ed., 2009.

O conceito de mérito em processo civil. In: Fundamentos do processo civil moderno. 6. ed. São Paulo: Malheiros Ed., 2010. v. 1, p. 299-348.

Direito e processo. In: Fundamentos do processo civil moderno. 6. ed. São Paulo: Malheiros Ed., 2010. v. 1.

. Instituições de direito processual civil. 6. ed. São Paulo: Malheiros Ed., 2009. 4 v.

- Os institutos fundamentais do processo civil. In: Fundamentos do processo civil moderno. 6. ed. São Paulo: Malheiros Ed., 2010. v. 1, p. 245-298.

. A instrumentalidade do processo. 13. ed. São Paulo: Malheiros Ed., 2008.

Relativizar a coisa julgada material. Revista Forense, Rio de Janeiro, v. 358, n. 97, nov./dez. 2001.

Sentença meramente declaratória, sentença condenatória e coisa julgada. In: Fundamentos do processo civil moderno. 6. ed. São Paulo: Malheiros Ed., 2010. v. 1 .

. As três figuras da liqüidação de sentença. In: Fundamentos do processo civil moderno. 6. ed. São Paulo: Malheiros Ed., 2010. v. 2, p. 1379-1412.

DINAMARCO, Pedro. Ação civil pública. São Paulo: Saraiva, 2001.

DWORKIN, Ronald. Taking rights seriously. Cambridge, Massachussets: Harvard University Press, 1979.

ESTELLITA, Guilherme. Da cousa julgada: fundamento político e extensão a terceiros. Tese. Rio de Janeiro, 1936. 
FABRÍCIO, Adroaldo Furtado. Ação declaratória incidental. 4. ed. São Paulo: Saraiva, 2009.

A coisa julgada nas ações de alimentos. Revista de Processo, São Paulo, n. 62, p. 9-27, abr./jun. 1991.

FAZZALARI, Elio. Il cammino della sentenza e della "cosa giudicata". Rivista di Diritto Processuale, Padova, v. 43, n. 3, p. 589-597, 1988.

Istituzioni de diritto processuale. 8. ed. Padova: Cedam, 1996.

Note in tema di diritto e processo. Milano: Giuffrè, 1957.

FERNANDES, André Dias. Limites imanentes à substituição processual na fase de cumprimento das ações coletivas. Revista Síntese de Direito civil e Processual Civil, Porto Alegre, n. 73, set./out. 2001.

FERNANDES, Sérgio Ricardo de Arruda. Alguns aspectos da coisa julgada no direito processual civil brasileiro. Revista de Processo, n. 62, p. 79-90, abr./jun. 1991.

FERRARESI, Eurico. Ação popular, ação civil pública e mandado de segurança coletivo: instrumentos processuais coletivos. Rio de Janeiro: Forense, 2009.

FISS, Owen. The political theory of the class action. In: The law as it could be. New York: New York University Press, 2003. p. 122-132.

FREIRE, Rodrigo Cunha Lima. O processo civil na sociedade da informação: estudo de um caso. Revista do Instituto dos Advogados de São Paulo, São Paulo, n. 17, jan. 2006.

GALANTER, Marc. Why the haves come out ahead: speculations on the limits of legal change. Law and Society Review, v. 9, 1974.

GAZZI, Mara Silvia. Os limites subjetivos da coisa julgada. Revista de Processo, São Paulo, n. 36, p. 79-113, out./dez. 1984.

GIDDENS, Anthony. As conseqüências da modernidade. São Paulo: Ed. UNESP, 1991.

GIDI, Antonio. A class action como instrumento de tutela coletiva dos direitos: as ações coletivas em uma perspectiva comparada. São Paulo: Ed. Revista dos Tribunais, 2007.

Coisa julgada e litispendência em ações coletivas. São Paulo: Saraiva, 1995.

A representação adequada nas ações coletivas brasileiras: uma proposta. Revista de Processo, n. 68, p. 102, out./dez. 2000. 
GIDI, Antonio; TESHEINER, José Maria Rosa; PRATES, Marília Zanella. Limites objetivos da coisa julgada no projeto de Código de Processo Civil: reflexões inspiradas na experiência norte-americana. Revista de Processo, São Paulo, n. 194, abr. 2011.

GIUSSANI, Andrea. Azioni colletive risarcitorie nel processo civile. Bologna: Il mulino, 2008.

. Studi sulle class action. Padova: CEDAM, 1996.

GOLDSHMIDT, James. Derecho procesal civil. Trad. de Leonardo Pietro Castro. Barcelona: Editorial Labor, 1936.

GOTTWALD, Petter; SCHWAB, Karl; ROSENBERG, Leo. Zivilprozessrecht. 17. ed. Munique: C.H. Beck Editor, 2010.

GRECO FILHO, Vicente. Direito processual civil brasileiro. 20. ed. São Paulo: Saraiva, 2009. v. 2.

GRINOVER, Ada Pellegrini. A ação civil pública refém do autoritarismo. Revista de Processo, São Paulo, n. 96, p. 28-36, out./dez. 1999.

- A coisa julgada. In: GRINOVER, Ada Pellegrini et al. Código Brasileiro de Defesa do Consumidor comentado pelos autores do anteprojeto. 8. ed. Rio de Janeiro: Forense, 2005. p. 905-907.

Coisa julgada erga omnes, secudum eventum litis e secundum probationem. Revista Forense, Rio de Janeiro, n. 380, p. 3-19. jul./ago. 2005.

Considerações sobre os limites objetivos e a eficácia preclusiva da coisa julgada. Revista do Advogado, São Paulo, v. 21, n. 65, p. 73-78, dez. 2001.

Da class action for damages à ação de classe brasileira: os requisitos de admissibilidade. Revista Forense, Rio de Janeiro, n. 352, p. 1-14, set./dez. 2000.

. Da defesa do consumidor em juízo. In: GRINOVER, Ada Pellegrini et al. Código Brasileiro de Defesa do Consumidor comentado pelos autores do anteprojeto. 8. ed. Rio de Janeiro: Forense, 2005. p. 777-779.

Das ações coletivas para a defesa de interesses individuais homogêneos. In: GRINOVER, Ada Pellegrini et al. Código Brasileiro de Defesa do Consumidor comentado pelos autores do anteprojeto. 8. ed. Rio de Janeiro: Forense, 2005. p. 854-902.

- Eficácia e autoridade da sentença: a teoria de Liebman no Código de Defesa do Consumidor e no Código Modelo de processos coletivos para Ibero-América. In: O processo: estudos e pareceres. São Paulo: Perfil, 2005, p. 202-211. 
GRINOVER, Ada Pellegrini. As garantias constitucionais do processo nas ações coletivas. Revista de Processo, n. 46, p. 19-30, jul./set. 1986.

. Notas a "Ações concorrentes" e "Pluralidade de partes legítimas à impugnação de um único ato". In: LIEBMAN, Enrico Tullio. Eficácia e autoridade da sentença e outros escritos sobre a coisa julgada. Tradução de Alfredo Buzaid e Benvindo Aires, com notas de Ada Pellegrini Grinover. 4. ed. Rio de Janeiro: Forense, 2007.

. Novas tendências em matéria de ações coletivas nos países de civil law. Revista de Processo, São Paulo, n.157, p. 147-164, mar. 2008.

O novo processo do consumidor. Revista de Processo, São Paulo, n. 62, p. 141152, abr./jun. 1991.

Significado social, político e jurídico da tutela dos direitos difusos. Revista de Processo, São Paulo, n. 97, p. 9-15, jan./mar. 2000.

. Significado social, político e jurídico da tutela dos direitos difusos. In: . A marcha do processo. Rio de Janeiro: Forense, 2000. p. 17-23.

et al. Código Brasileiro de Defesa do Consumidor comentado pelos autores do anteprojeto. 8. ed. Rio de Janeiro: Forense, 2005.

; MULLENIX, Linda; WATANABE, Kazuo. Os processos coletivos nos países de civil law e common law: uma análise de direito comparado. XIII Congresso internacional de direito processual civil. São Paulo: Ed. Revista dos Tribunais, 2008.

GUASP, Jaime; ARAGONESES, Pedro. Derecho procesal civil: introducción y parte general. 7. ed. Cizur Menor (Navarra): Thompson-Civitas, 2005. t. 1.

GUERRA FILHO, Willis Santiago. Reflexões a respeito da natureza da coisa julgada como problema filosófico. Revista de Processo, São Paulo, n. 58, p. 244-249, abr./jun. 1990.

HEINITZ, Ernesto. Limitti oggettivi della cosa giudicata. Padova: CEDAM, 1937.

HENSLER, Deborah et al. Class action dilemmas: pursuing public goals for private gain. Santa Monica, California: Rand Institute for Civil Justice, 2000.

; HODGES, Christopher; TULIBACKA, Magdalena (Eds.). The globalization of class actions: an overview. Thousand Oaks, California: Sage Publications, 2009. (The Annals of the American Academy of Political and Social Science Series, v. 622).

HODGES, Christopher. The reform of class and representative actions in European legal systems: a new framework for collective redress in Europe. Oxford and Portland: Hart Publishing, 2008. 
JONES, Craig. Theory of class actions: optimal aggregation in mass tort litigation. Toronto: Irwin Law, 2003.

KARAS, Stan. The role of fluid recovery in consumer protection litigation: Kraus v. Trinity Management Services. California Law Review, n. 959, May 2002.

KLONOFF, Robert H. Class actions and other multi party litigation: in a nutshell. $3^{\mathrm{a}}$ ed., St. Paul: Thomson West, 2007.

LACERDA, Galeno. Despacho saneador. 3. ed. Porto Alegre: Sérgio Antonio Fabris, 1990.

LEAL, Márcio Flávio Mafra. Ações coletivas: história, teoria e prática. Porto Alegre: Sérgio Antonio Fabris Editor, 1998.

LENZA, Pedro. Teoria geral da ação civil pública. 3. ed. São Paulo: Ed. Revista dos Tribunais, 2008.

LEONEL, Ricardo de Barros. Causa de pedir e pedido nos processos coletivos: uma nova equação para a estabilização da demanda. In: GRINOVER, Ada Pellegrini; MENDES, Aluísio Gonçalves de Castro; WATANABE, Kazuo (Coords.). Direito processual coletivo e o Anteprojeto de Código Brasileiro de Processos Coletivos. São Paulo: Ed. Revista dos Tribunais, 2007.

. Causa de pedir e pedido: o direito superveniente. São Paulo: Método, 2006.

- A causa petendi nas ações coletivas. In: TUCCI, José Rogério Cruz e; BEDAQUE, José Roberto dos Santos (Coords.). Causa de pedir e pedido no processo civil: questões polêmicas. São Paulo: Revista dos Tribunais, 2002.

. Manual do processo coletivo. São Paulo: Ed. Revista dos Tribunais, 2002.

LIEBMAN, Enrico Tullio. Ações concorrentes. In: Eficácia e autoridade da sentença e outros escritos sobre a coisa julgada. Tradução de Alfredo Buzaid e Benvindo Aires, com notas de Ada Pellegrini Grinover. 4. ed. Rio de Janeiro: Forense, 2007. p. 209-219.

. O despacho saneador e o julgamento do mérito. In: Estudos sobre o processo civil brasileiro. 2. ed. São Paulo: Bushatsky, 1976. p. 95-135.

Efeitos da sentença e coisa julgada. In: - Eficácia e autoridade da sentença e outros escritos sobre a coisa julgada. Tradução de Alfredo Buzaid e Benvindo Aires, com notas de Ada Pellegrini Grinover. 4. ed. Rio de Janeiro: Forense, 2007. p. 274-284. 
LIEBMAN, Enrico Tullio. Eficácia e autoridade da sentença. Tradução de Alfredo Buzaid e Benvindo Aires, com notas de Ada Pellegrini Grinover. In: Eficácia $e$ autoridade da sentença e outros escritos sobre a coisa julgada. Tradução de Alfredo Buzaid e Benvindo Aires, com notas de Ada Pellegrini Grinover. 4. ed. Rio de Janeiro: Forense, 2007. p. 1-162.

A força criativa da jurisprudência e os limites impostos pelo texto da lei. Revista de Processo, São Paulo, n. 43, p. 57-60, jul./set. 1986.

Limites da coisa julgada em matéria de imposto. I In: Estudos sobre o processo civil brasileiro. 2. ed. São Paulo: Bushatsky, 1976.

Limites objetivos da coisa julgada. In: Estudos sobre o processo civil brasileiro. 2. ed. São Paulo: Bushatsky, 1976. p. 155-164.

. Manual de direito processual civil. Trad. e notas: Cândido Rangel Dinamarco. 3. ed. São Paulo: Malheiros Ed., 2005. v. 1.

. Manuale di diritto processuale civile. 4. ed. Milano: Giuffrè, 1984. v. 2.

Manuale di diritto processuale civile: principi. 7. ed., a cura di Vittorio Colesanti, Elena Merlin, Edoardo Ricci. Milano: Giuffrè, 2007.

_.$<$ Parte $>>$ o $<<$ capo $>>$ di sentenza. Rivista di Diritto Processuale, Padova, 1964.

- Pluralidade de partes legítimas à impugnação de um único ato. In:

Eficácia e autoridade da sentença e outros escritos sobre a coisa julgada. Tradução de Alfredo Buzaid e Benvindo Aires, com notas de Ada Pellegrini Grinover. 4. ed. Rio de Janeiro: Forense, 2007.

. Processo de execução, 3. ed. São Paulo: Saraiva, 1968.

LOMBARDI, Mariana Capela. Da coisa julgada civil: limites subjetivos e extensão a terceiros. 2008. Dissertação (Mestrado) - Faculdade de Direito da Universidade de São Paulo, 2008.

LUCON, Paulo Henrique dos Santos; GABBAY, Daniela Monteiro; ALVES, Rafael Francisco; ANDRADE, Tathyana Chaves. Interpretação do pedido e da causa de pedir nas ações coletivas (conexão, continência e litispendência). In: LUCON, Paulo Henrique dos Santos (Coord.). Tutela coletiva: 20 anos da lei da ação civil pública e do fundo de direitos difusos. 15 anos do Código de Defesa do consumidor. São Paulo: Atlas, 2006. p. 184-199.

; SILVA, Érica Barbosa e. Análise crítica da liqüidação e execução na tutela coletiva. In: LUCON, Paulo Henrique dos Santos (Coord.). Tutela coletiva: 20 anos da lei da ação civil pública e do fundo de direitos difusos. 15 anos do Código de Defesa do consumidor. São Paulo: Atlas, 2006. p. 163-183. 
LUHMANN, Niklas. Legitimação pelo procedimento. Brasília: Ed. Universidade de Brasília, 1980.

MACHADO GUIMARÃES, Luiz. Estudos de direito processual civil. Rio de Janeiro; São Paulo: Livraria Jurídica e Universitária, 1969.

MANCUSO, Rodolfo de Camargo. Ação civil pública: em defesa do meio ambiente, do patrimônio cultural e dos consumidores. 12. ed. São Paulo: Ed. Revista dos Tribunais, 2011.

. Acesso à justiça: condicionantes legítimas e ilegítimas. São Paulo: Ed. Revista dos Tribunais, 2011.

Coisa julgada, "collateral estoppel" e eficácia preclusiva "secundum eventum litis”. Revista dos Tribunais, São Paulo, n. 608, jun. 1986.

Interesses difusos: conceito e legitimação para agir. 6. ed., São Paulo: Ed. Revista dos Tribunais, 2004.

Jurisdição coletiva e coisa julgada: teoria geral das ações coletivas. 2. ed. São Paulo: Ed. Revista dos Tribunais, 2007.

A projetada participação eqüânime dos co-legitimados à propositura da ação civil pública: da previsão normativa à realidade forense. Revista dos Tribunais, São Paulo, n.796, p. 11-38, fev. 2002.

A resolução dos conflitos e a função judicial no contemporâneo Estado de Direito. São Paulo: Ed. Revista dos Tribunais, 2009.

. Titularidade do direito, legitimação para agir e representação processual. Revista dos Tribunais, São Paulo, n. 771, jan. 2000.

MARCUS, Richard; REDISH, Martin; SHERMAN, Edward; PFANDER, James. Civil procedure: a modern approach. 5. ed. St. Paul, MN: West Publishing Co., 2009.

; SHERMAN, Edward. Complex litigation: cases and materials on advanced civil procedure. Thomson-West, 2004.

MARINONI, Luiz Guilherme. Coisa julgada inconstitucional. São Paulo: Ed. Revista dos Tribunais, 2008.

Técnica processual e tutela dos direitos. 2. ed. São Paulo: Ed. Revista dos Tribunais, 2008.

; ARENHARDT, Sérgio. Execução. 2. ed. São Paulo: Ed. Revista dos Tribunais, 2008 . 
MARINONI, Luiz Guilherme; ARENHARDT, Sérgio. Manual do processo de conhecimento. 5. ed. São Paulo: Ed. Revista dos Tribunais, 2006.

MARQUES, José Frederico. Instituições de direito processual civil. 3. ed. Rio de Janeiro: Forense, 1966. v. 4.

MOTELEONE, Girolamo. I limitti soggettivi del giudicato civile. Padova: CEDAM, 1978.

MAURINO, Gustavo; NINO, Ezequiel; SIGAL, Martín. Las acciones colectivas: análisis conceptual, constitucional, procesal, jurisprudencial y comparado. Buenos Aires: Lexis Nexis Argentina, 2005.

MAZZILI, Hugo de Nigro. A defesa dos interesses difusos em juízo. 19. ed. São Paulo: Saraiva, 2006.

MENCHINI, Sergio. Il giudicato civile. Torino: UTET, 2002.

MENDES, Aluisio Gonçalves de Castro. Ações coletivas no direito comparado e nacional. 2. ed. São Paulo: Ed. Revista dos tribunais, 2010.

A coisa julgada e os processos coletivos no direito vigente e no projeto de nova lei da ação civil pública. In: GOZZOLI, Maria Clara; CIANCI, Mirna; CALMON, Petrônio; QUARTIERI, Rita. Em defesa de um novo sistema de processos coletivos: estudos em homenagem a Ada Pelegrini Grinover. São Paulo: Saraiva, 2010. p. 67-77.

MENDES, João de Castro. Limites objectivos do caso julgado em processo civil. Lisboa: Ática, 1968.

MENDONÇA LIMA, Alcides de. Liqüidação de sentença. In: FRANÇA, Rubens Limongi (Org.). Enciclopédia Saraiva do Direito. São Paulo: Saraiva, 1980.v. 50.

MENESTRINA, Francesco. La pregiudiciale nel processo civile. Milano: Giuffrè, 1963.

MILLER, Arthur. Of Frankenstein monsters and shining knights: myth, reality, and the 'class action problem'. Harvard Law Review, v. 92, p. 664-694, Jan. 1979.

MONTELEONE, Girolamo. I limiti soggetivi del giudicato civile. Padova: CEDAM, 1978.

MONTERO AROCA, Juan. Derecho jurisdiccional. 10. ed. Valencia: Tirant lo Blanch, 2000. v. 1.

.. El derecho procesal en el siglo XX. Madrid: Tirant lo Blanch, 2000.

MONTESQUIEU, Charles de Secondat, Baron de. O espírito das leis. 2. ed. São Paulo: Martins Fontes, 2006. 
MORTARA, Lodovico. Commentario del codice e dele leggi di procedura civile. 4. ed. Milano: Francesco Vallardi Editor, 1923. v. 4.

MOURÃO, Luiz Eduardo Ribeiro. Coisa julgada. Belo Horizonte: Editora Fórum, 2008.

MULLENIX, Linda S. Mass tort litigation: cases and materials. 2. ed. St. Paul: West Publishing Co., 2008.

NAGAREDA, Richard A. The law of class actions and other aggregate litigation. New York: Foundation Press, 2009.

NEKATSCHALOW, André. A coisa julgada nas relações continuativas. 1995. Dissertação (Mestrado) - Faculdade de Direito da Universidade de São Paulo, São Paulo, 1995.

NERY JUNIOR, Nelson. Princípios do processo na Constituição Federal. 10. ed. São Paulo: Ed. Revista dos Tribunais, 2010.

NEVES, Celso. Contribuição ao estudo da coisa julgada civil. Tese (Cátedra). Faculdade de Direito, Universidade de São Paulo, São Paulo, 1970.

. Estrutura fundamental do processo civil. Rio de Janeiro: Forense, 1997.

NEVES, Daniel Amorim Assumpção. Preclusões para o juiz: preclusão pro judicato e preclusão judicial no processo civil. São Paulo: Método, 2004.

OLIVEIRA, Carlos Alberto Alvaro. Alienação da coisa litigiosa. 2. ed. Rio de Janeiro: Forense, 1984.

OLIVEIRA, Swarai Cervone. Poderes do juiz nas ações coletivas. São Paulo: Atlas, 2009.

OLIVEIRA JUNIOR, Waldemar Mariz de. Substituição processual. São Paulo: Ed. Revista dos Tribunais, 1971.

Tutela jurisdicional dos interesses coletivos. Revista de Processo, São Paulo, n. 33, p. 7, jan./mar. 1984.

OLIVEIRA LIMA, Paulo Roberto. Contribuição à teoria da coisa julgada. São Paulo: Ed. Revista dos Tribunais, 1997.

OTERO, Paulo. Ensaio sobre o caso julgado inconstitucional. Lisboa: Lex, 1993.

PAGENSTECHER, Max. Zur lehre von der materiellen rechtkraft. Berlim: Franz Vahlen, 1904. 
PAULA BAPTISTA, Francisco de. Compendio de theoria e prática do processo civil comparado com o comercial e de hermenêutica jurídica. 4. ed. Rio de Janeiro: Garnier Editor, 1890.

PFEIFFER, Roberto Augusto Castellanos. Tutela coletiva da livre concorrência. Revista de Direito do Consumidor, p. 11-39. jan./mar. 2004.

PICARDI, Nicola. Do juízo ao processo. In: Jurisdição e processo. Rio de Janeiro: Forense, 2008.

A vocação de nosso tempo para a jurisdição. In: . Jurisdição e processo. Rio de Janeiro: Forense, 2008. p. 1-32.

PIVA RODRIGUES, Walter. Coisa julgada tributária. São Paulo: Quartier Latin, 2008.

A crise no conceito da coisa julgada, em especial em matéria tributária. Revista do Advogado, São Paulo, ano 26, n. 88, p. 193-200, 2006.

O mandado de segurança contra atos judiciais na atual realidade forense. In: SALLES, Carlos Alberto de (Coord.). As grandes transformações do processo civil brasileiro: homenagem ao professor Kazuo Watanabe. São Paulo: Quartier Latin, 2009. p. 477-486.

O princípio da colegialidade das decisões nos tribunais. Revista Dialética de Direito Processual, São Paulo, v. 1, p. 176-178, 2003.

- O recurso tido como inexistente em instância especial por falta de procuração. Revista Dialética de Direito Processual, São Paulo, v. 32, p. 118-121, 2005.

Sobre os limites objetivos da coisa julgada em matéria tributária. 1989. Tese (Doutorado) - Faculdade de Direito, Universidade de São Paulo, São Paulo, 1989.

Súmula vinculante em matéria processual. Revista do Tribunal Regional do Trabalho da 15ª Região, Campinas, v. 1, p. 182-186, 2002.

PIZZOL, Patrícia Miranda. Liqüidação nas ações coletivas. São Paulo: Lejus, 1988.

PONTES DE MIRANDA, Francisco Cavalcanti. Comentários ao Código de Processo Civil: arts. 444 a 475. 3. ed. Rio de Janeiro: Forense, 1997. t. 5.

. Comentários ao Código de Processo Civil. Rio de Janeiro: Forense, 1997. t. 9.

PORTO, Sérgio Gilberto. Coisa julgada civil. 3. ed. São Paulo: Ed. Revista dos Tribunais, 2006.

- Sobre o propósito e alcance do Artigo 474, do CPC. Revista Síntese de Direito Civil e Processual Civil, Porto Alegre, v. 1, n. 1, p. 39-47, set./out. 1999. 
PROTO PISANI, Andrea. Appunti preliminari per uno studio sulla tutela giurisdizionale degli interessi collettivi (o più esattamente superindividuali) innanzi al giudice civile ordinario. In: Le azioni a tutela di interessi colletivi: atti del convegno si studio (Pavia, 1112 giug. 1974. Padova: CEDAM, 1976.

. Lezioni di diritto processuale civile. Napoli: Jovene, 1996.

. Lezioni di diritto processuale civile. 5. ed. Napoli: Jovene, 2006.

. Le tutele giurisdizionali dei diritti: studi. Napoli: Jovene, 2003.

PUGLIESE, Giovanni. Giudicato civile: diritto vigente. In: Enciclopedia del diritto. Milano: Giuffrè, 1969. v. 18, p. 785-893.

. Giudicato civile (storia). In: Enciclopedia del diritto. Milano: Giuffrè, 1969. v. 18.

REDENTI, Enrico. Diritto processuale civile. Milano: Giuffrè, 1957. v. 3.

Il giudicato sul punto di diritto. Rivista Trimestrale di diritto e procedura civile, anno 3, p. 257-270, 1949.

REISCHL, Klaus. Die objektiven Grenzen der Rechtskraft im Zivilprozeß. Mohr Siebeck, 2002.

ROCCO, Alfredo. La sentencia civil. Trad. de Mariano Ovejero. Buenos Aires: Libreria El Foro, 2003.

RODRIGUES, Ruy Zoch. Ações repetitivas: casos de antecipação de tutela sem o requisito de urgência. São Paulo: Ed. Revista dos Tribunais, 2010.

ROGNONI, Virginio. Carattere della pronuncia di condanna generica. Rivista di Diritto Processuale, Padova, v. 7, p. 105-116, 1952.

ROSENBERG, Leo. Tratado de derecho procesal civil. Buenos Aires: Ediciones Jurídicas Europa-América, 1955. t. 2.

ROUSSEAU, Jean Jacques. O contrato social. 3. ed. São Paulo: Martins Fontes, 1996.

SALLES, Carlos Alberto de. Políticas públicas e legitimidade para a defesa de interesses difusos e coletivos. Revista de Processo, São Paulo, n. 121, p. 38-50, mar. 2005.

Processo civil de interesse público. In: (Org.). Processo civil e interesse público: o processo como instrumento de defesa social. São Paulo, Revista dos Tribunais, 2003. p. 39-77.

SANCHES, Sidney. Objeto do processo e objeto litigioso do processo. Revista de Processo, São Paulo, n. 13, jan./mar. 1979. 
SANTOS, Andrés de la Oliva. Objeto del proceso y cosa juzgada en el proceso civil. Cizur Menor,Navarra: Thomson Civitas, 2005.

SANTOS, Moacyr Amaral. Primeiras linhas de direito processual civil. 3. ed. São Paulo: Saraiva, 1979. v. 3.

SATTA, Salvatore; PUNZI, Carmine. Diritto processuale civile. 13. ed. Padova: CEDAM, 2000 .

SAVIGNY, Friedrich Karl. Sistema del derecho romano actual. Madrid: F. Góngora e Compañia, 1879. t. 5.

. Vocazione del nostro secolo per la legislazione e la giurisprudenza. Bologna: Forni, 1968.

SCHUMPETER, Joseph. Capitalism, socialism and democracy. New York: Harper Collins, 2008.

SCHWAB, Karl Heinz. El objeto litigioso en el proceso civil. Buenos Aires: Ejea, 1968.

SICA, Heitor Vitor Mendonça. A nova liqüidação de sentença e suas velhas questões. In: BUENO, Cássio Scarpinella; WAMBIER, Teresa Arruda Alvim (Coords.). Aspectos polêmicos da nova execução. São Paulo: Revista dos Tribunais, 2008. v. 4, p. 210-239.

Preclusão processual civil. 2. ed. São Paulo: Atlas, 2008.

SILVA, Edson Ferreira da. Da legitimação extraordinária, inclusive na Constituição de 1988. Revista de Processo, São Paulo, n. 64, p. 80-91, out./dez. 1991.

SILVA, Érica Barbosa e. Cumprimento de sentença em ações coletivas. São Paulo: Atlas, 2009.

Os direitos individuais homogêneos e a Lei n. 11.232/2002. In: SALLES, Carlos Alberto de (Coord.). As grandes transformações do processo civil brasileiro: homenagem ao professor Kazuo Watanabe. São Paulo: Quartier Latin, 2009. p. 343-368.

SILVA, Ovídio Baptista. Coisa julgada relativa? Revista dos Tribunais, São Paulo, v. 93, n. 821, p. 29-38, mar. 2004.

Conteúdo da sentença e coisa julgada. In: Sentença e Coisa Julgada: ensaios e pareceres. 4. ed. Rio de Janeiro: Forense, 2003, p. 163-183.

Conteúdo da sentença e mérito da causa. In. Sentença e coisa julgada: ensaios e pareceres. 4. ed. Rio de Janeiro: Forense, 2003. p. 231-244.

- Eficácias da sentença e coisa julgada. In. Sentença e coisa julgada: ensaios e pareceres. 4. ed. Rio de Janeiro: Forense, 2003. p. 71-82. 
SILVA, Ovídio Baptista. Os limites objetivos da coisa julgada no atual direito brasileiro atual. In. . Sentença e coisa julgada: ensaios e pareceres. 4. ed. Rio de Janeiro: Forense, 2003. p. 103-138.

SOUZA, Gelson Amaro. Notas sobre a liqüidação de sentença. Revista de Processo, São Paulo, n. 64, p. 56-69, out./dez. 1991.

SOUZA JÚNIOR, Sidney Pereira. Sentenças parciais no direito processual civil: conseqüências no âmbito recursal. São Paulo: Método, 2010.

STUART MILL, John. Considerations on representative government. Rockville, Maryland: Serenity Publishers, 2008.

TALAMINI, Eduardo. Coisa julgada e sua revisão. São Paulo: Ed. Revista dos Tribunais, 2005.

A coisa julgada no tempo: os "limites temporais" da coisa julgada. Revista do Advogado, São Paulo, n. 88, p. 56-63, nov. 2006.

- Partes, terceiros e coisa julgada: os limites subjetivos da coisa julgada. In: DIDIER JR., Fredie; WAMBIER, Teresa Arruda Alvim (Coords.). Aspectos polêmicos e atuais sobre os terceiros no processo civil e assuntos afins. São Paulo: Revista dos Tribunais, 2004.

TAPÍA FERNANDÉZ, Isabel. La cosa juzgada: estudio de jurisprudencia civil. Madrid: Editorial Dykinson, 2010.

TARUFFO, Michele. $<<$ Collateral Estoppel $>>$ e giudicato sulle questioni. Rivista di Diritto Processuale, Padova, anno 27, n. 2, p. 272-300, apr./giug. 1972.

Legalità e giustificazione della creazione giudiziaria del diritto. In: Sui confini: scritti sulla giustizia civile. Bologna: Il Mulino, 2002.

. Razionalità e crisi della legge processuale, In: . Sui confini: scritti sulla giustizia civile. Bologna: Il Mulino, 2002. p. 55-56.

TESHEINER, José Maria Rosa. Autoridade e eficácia da sentença: crítica à teoria de Liebman. Revista dos Tribunais, São Paulo, n. 744, abr. 2000.

. Eficácia da sentença e coisa julgada no processo civil. São Paulo: Ed. Revista dos Tribunais, 2002.

THEODORO JÚNIOR, Humberto. Algumas observações sobre a ação civil pública e outras ações coletivas. Revista Síntese de Direito Civil e Processual Civil, Porto Alegre, v. 3 n. 9, p. 139-159, jan./fev. 2001. 
THEODORO JÚNIOR, Humberto. A preclusão no processo civil. Revista dos Tribunais, São Paulo, n. 784, fev. 2001.

- Redimensionamento da coisa julgada. Revista Síntese de Direito Civil e Processual Civil, Porto Alegre, n. 58, mar./abr. 2009.

; FARIA, Juliana Cordeiro de. A coisa julgada inconstitucional e os instrumentos processuais para seu controle. Revista dos Tribunais, São Paulo, n. 795, jan. 2002.

TIDMARSH, Jay; TRANSGRUD, Roger. Complex litigation: problems in advanced civil procedure. New York: Foundation Press, 2002.

TUCCI, Rogério de Láuria. Ação civil pública: abusiva utilização pelo Ministério Público e distorção pelo Poder Judiciário. In: WALD, Arnoldo. Aspectos polêmicos da ação civil pública. 2. ed. São Paulo: Saraiva, 2007. p. 355-392.

VELLANI, Mario. Appunti sulla natura della cosa giudicata. Milano: Giuffrè, 1958.

. Naturaleza de la cosa juzgada. Traducción de Santiago Sentís Melendo. Buenos Aires: Edicciones Juridícas Europa-America, 1963.

VENTURI, Elton. Processo civil coletivo: a tutela dos interesses difusos, coletivos e individuais homogêneos no Brasil. São Paulo: Malheiros Ed., 2007.

VERDE, Giovanni. Sulla <<minima unità sttruturale $>>$ azionabile nel processo: (a proposito di giudicato e di dottrine emergenti). Rivista di Diritto Processuale, Padova, 1989.

VIEHWEG, Theodor. Tópica e jurisprudência: uma contribuição à investigação dos fundamentos jurídico-científicos. Porto Alegre: Sérgio Antonio Fabris, 2008.

VIGLIAR, José Marcelo Menezes. Ação civil pública ou ação coletiva? In: MILARÉ, Édis (Org.). Ação civil pública: Lei 7.347/1985 - 15 anos. 2. ed. São Paulo: Ed. Revista dos Tribunais, 2002.

A causa de pedir e os interesses individuais homogêneos. In: TUCCI, José Rogério Cruz e; BEDAQUE, José Roberto dos Santos (Coords.). Causa de pedir e pedido no processo civil: questões polêmicas. São Paulo: Ed. Revista dos Tribunais, 2002.

Interesses individuais homogêneos e seus aspectos polêmicos. 2. ed. São Paulo: Saraiva, 2008.

- Pedido genérico e projeto de sentença. In: TUCCI, José Rogério Cruz e; BEDAQUE, José Roberto dos Santos (Coords.). Causa de pedir e pedido no processo civil: questões polêmicas. São Paulo: Ed. Revista dos Tribunais, 2002. 
VIGORITI, Vincenzo. Interessi collettivi e processo: la legittimazione ad agire. Milano: Giuffrè, 1979.

VOLPINO, Diego. L'oggetto del giudicato nell'esperienza americana. Padova: CEDAM, 2007.

WAMBIER, Luiz Rodrigues. Considerações sobre a liqüidação de sentença coletiva na proposta do Código-modelo de processo coletivo para a Ibero-América. Revista de Processo, São Paulo, n. 121, p. 149-168, jul./ago. 2004.

Liqüidação da sentença civil: individual e coletiva. 4. ed. reformulada, atualizada e ampliada da obra Sentença civil: liqüidação e cumprimento. São Paulo: Ed. Revista dos Tribunais, 2009.

; WAMBIER, Teresa Arruda Alvim. Anotações sobre a liqüidação e execução nas ações coletivas. In: GRINOVER, Ada Pellegrini, MENDES, Aluisio Gonçalves de Castro; WATANABE, Kazuo (Orgs.). Direito processual coletivo e o anteprojeto de Código Brasileiro de Processos Coletivos. São Paulo: Ed. Revista dos Tribunais, 2007. p. 263-280.

WAMBIER, Teresa Arruda Alvim. Nulidades do processo e da sentença. 6. ed. São Paulo: Ed. Revista dos Tribunais, 2007.

; MEDINA, José Miguel. O dogma da coisa julgada: hipóteses de relativização. São Paulo: Ed. Revista dos Tribunais, 2003.

WATANABE, Kazuo. Da cognição no processo civil. 2. ed. São Paulo: Central de Publicações Jurídicas, 1999.

Demandas coletivas e os problemas emergentes da práxis forense. Revista de Processo, São Paulo, n. 61, jul./set. 1992.

Relação entre demanda coletiva e demandas individuais. Revista de Processo, São Paulo, n. 139, set. 2006.

WEBER, Max. Economia e sociedade: fundamentos da sociologia compreensiva. 4. ed. Brasília: Ed. Universidade de Brasília, 2004. v. 1.

WINDSCHEID, Bernhard; MUTHER, Theodor. Polemica in torno all'actio. Trad. de Giovanni Pugliese e Ernesto Heinitz. Firenze: Sansoni, 1954.

WOLFF, Tobias Barrington. Preclusion in class action litigation. Columbia Law Review, v. 105, p. 717-808, 2005.

YEAZELL, Stephen. Group litigation and social context. Columbia Law Review, v. 77, 1977. 
ZAVASCKI, Teori. Defesa de direitos coletivos e defesa coletiva de direitos. Revista Forense, Rio de Janeiro, n. 329, p. 147-160, jan./mar. 1995.

Processo coletivo: tutela de direitos coletivos e tutela coletiva de direitos. 4. ed. São Paulo: Ed. Revista dos Tribunais, 2009.

ZUFELATO, Camilo. Coisa julgada coletiva. São Paulo: Saraiva, 2011. 